Portland State University

PDXScholar

\title{
Distribution, Geochronology, and Petrogenesis of the Picture Gorge Basalt with Special Focus on Petrological Relationships to the Main Columbia River Basalt Group
}

Emily Bogdan Cahoon

Portland State University

Follow this and additional works at: https://pdxscholar.library.pdx.edu/open_access_etds

Part of the Geochemistry Commons, and the Geology Commons Let us know how access to this document benefits you.

\section{Recommended Citation}

Cahoon, Emily Bogdan, "Distribution, Geochronology, and Petrogenesis of the Picture Gorge Basalt with Special Focus on Petrological Relationships to the Main Columbia River Basalt Group" (2020). Dissertations and Theses. Paper 5609.

https://doi.org/10.15760/etd.7481

This Dissertation is brought to you for free and open access. It has been accepted for inclusion in Dissertations and Theses by an authorized administrator of PDXScholar. Please contact us if we can make this document more accessible: pdxscholar@pdx.edu. 
Distribution, Geochronology, and Petrogenesis of the Picture Gorge Basalt with Special Focus on Petrological Relationships to the Main Columbia River Basalt Group

by

Emily Bogdan Cahoon

A dissertation submitted in partial fulfillment of the requirements for the degree of

Doctor of Philosophy

in

Earth, Environment and Society

\author{
Dissertation Committee: \\ Martin J. Streck, Chair \\ John Bershaw \\ Anthony A.P. Koppers \\ John A. Wolff \\ Rossitza Wooster
}

Portland State University

2020 
(C) 2020 Emily Bogdan Cahoon 


\begin{abstract}
The Columbia River Basalt Group (CRBG) is the youngest and volumetrically smallest continental flood basalt exposed across the Pacific Northwest, USA. Similar to other large igneous provinces, the majority of material erupted during the initial 1 million years of activity, these lavas are subdivided into four main-phase units. The Picture Gorge Basalt (PGB) is the only main-phase unit of the CRBG whose age is not precisely known and understanding of PGB petrogenesis is largely based on a limited number of samples when compared with other main-phase units. It is suggested that a time gap of over 0.5 myr existed between eruptions of Steens Basalt and PGB (Wolff et al., 2013), however my initial results suggest otherwise as I have identified PGB interstratified between Steens Basalt flows in added extent near the Malheur Gorge.

Age constraint is critical to developing a petrologic and eruptive model that supports the geochemical data. Geochronological work via ${ }^{40} \mathrm{Ar}-{ }^{39} \mathrm{Ar}$ analysis constrains the timing of PGB eruptions and demonstrates that these lavas were the earliest and had the longest eruptive interval. Eruptions of PGB lavas span approximately 1.4 million years, potentially occurring as two discrete pulses. The first pulse occurred as the initial pulse of CRBG eruptive activity, and the second erupted contemporaneous with the Grande Ronde Basalt. This corroborates previous field observations of PGB and Grande Ronde Basalt lavas being interstratified, as the youngest PGB age ranges down to $15.76 \pm$ 0.11 Ma.
\end{abstract}

The spatial distribution of PGB lavas were thought to be relatively confined to the type locality of Picture Gorge in eastern Oregon. However newly identified basaltic lavas 
and dikes geochemically correlative to the PGB indicates this CRBG unit covers a larger areal extent than previously recognized. Combining stratigraphic correlation and geochemical similarities with ${ }^{40} \mathrm{Ar} /{ }^{39} \mathrm{Ar}$ geochronology, I am able to extrapolate the spatial extent of early and later PGB eruptions to newly correlated PGB lava flows and dikes. With the oldest age of $17.23 \pm 0.04 \mathrm{Ma}$, the PGB erupted earlier and longer than other CRBG main-phase unit, and CRBG volcanism initiated over a broad region that includes Picture Gorge.

Geochemical and isotopic signatures observed in the PGB suggest contributions from two primitive $(\mathrm{Mg \#}>58)$ compositional groups. Based on MELTS modeling, these basaltic compositions produce two different evolutionary patterns. The geochemical diversity of the PGB however cannot be attributed exclusively to fractionation of either composition, and PGB magmas were likely modified by crustal contamination. The wide distribution of PGB volcanism was likely the result of PGB lavas traveling further than previously recognized, although local tapping of a similar mantle to produce PGB-like lavas is also plausible

This research identifies three primary hypotheses, 1. Lava flows and dikes of the PGB were emplaced earlier than previously recognized and have a longer eruptive duration based on observed stratigraphic relationships, 2. Newly identified exposures of volcanic material geochemically correlated to PGB suggests this CRBG unit erupted across a wide spatial footprint of eastern Oregon, and therefore reflects a larger volume of this continental flood basalt, and 3. There is more than one significant contributing mantle component which yields PGB, and isotopic differences suggest that these components were not all depleted. The broader significance of this work expands the 
initial magmatic footprint for CRBG eruptions and highlights two temporal pulses of eruptive activity in PGB volcanism, also demonstrated by all CRBG ages. The revised distribution area of PGB increases the total eruptive volume of this continental flood basalt and when coupled with ages illustrates a clearer picture of spatial and temporal relationships to other main-phase CRBG units. Geochemical signatures in PGB lavas indicate at least two mantle components which reflect fluctuations in their contributions through time. 


\section{DEDICATION}

This dissertation is dedicated to all the post offices that are no longer with us. 


\section{ACKNOWLEDGEMENTS}

To my committee members Martin Streck, John Wolff, John Bershaw, Anthony Koppers, and Rossitza Wooster - thank you for your energy and encouragement over the last five years. Especially to Martin Streck for the time and dedication in the classroom and in the field, and continuously working with me on edits for our manuscript(s) and this dissertation.

I would also like to thank my friends at colleagues in Pullman for their company and relentless support; Jason McClaughry and Mark Ferns for their insights and discussions in the field; and Vic Camp, Don Swanson, and an anonymous reviewer for comments and edits that helped to improve the final manuscript of the age portion of Chapter 1, along with John Wolff for additional support and comments towards publishing. I am deeply grateful to Richard Carlson at the Carnegie Institute for his scientific guidance with all isotopic analyses and ability to explain complex topics with extreme clarity. Thank you to all who I have had the opportunity to work and spend time with at the ArAr Geochronology Lab at Oregon State University. And to my fellow NBP shipmates, I will never forget our months at sea.

To all of my officemates and field/ laboratory assistants over the years - it's been a wild ride! You provided wonderful company, conversation, and even tolerated side trips to various post offices and sunstone mines - Eli Ahern, Luna Brett, Tessa Carlson, 'Gem' Yang, Chanel Dvorak, Bethany Carder, Shelby Isom, Molly Ellowitz, Stephanie Welch, Caitlin Kirby, Lena Fox, Drew Jackson, Cassandra Black, Alison Horst, Mary Mass, and Vanessa Swenton - who loves chili offerings. And a massive thank you to Kellie Wall, Allan Lerner, and all members of the VolcOR community near and far!

To my family and friends back east - thank you for the encouragement and patience. Especially my parents for instilling a love of geology in me at an early age, even if rock-collecting included some light trespassing. For always saying 'I thought you were a tough kid?'- giving me the work ethic to maintain and handle 4+ side jobs while getting my $\mathrm{PhD}$. And lastly... for introducing me to Harry Dalton in $5^{\text {th }}$ grade.

Finally, I would like to thank my husband Andrew McCoy for the continuous emotional and financial support over the last five years. We made a plan and saw it through. You always lifted my spirits and helped keep things in perspective, I could not have accomplished this without you. 


\section{TABLE OF CONTENTS}

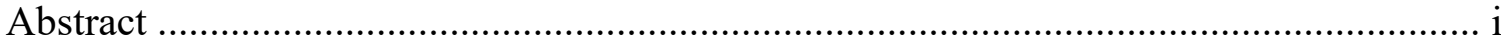

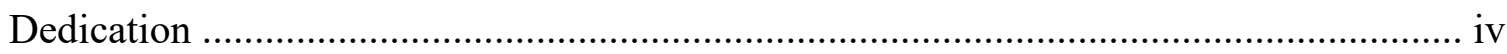

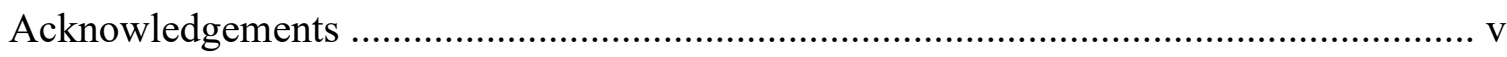

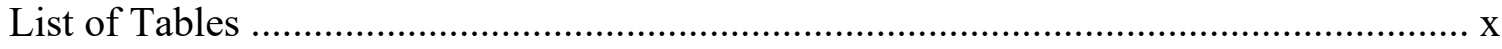

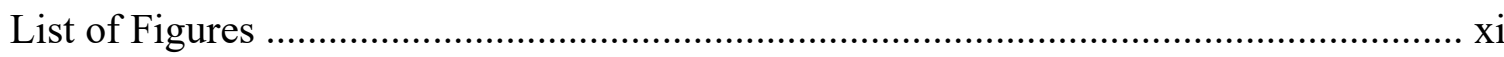

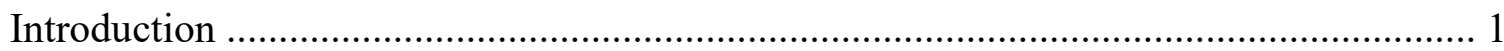

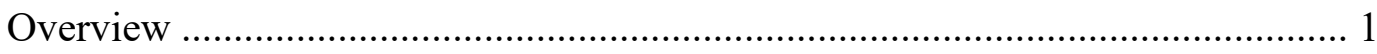

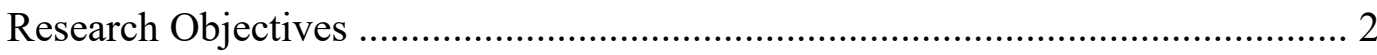

Continental Flood Basalts ............................................................................... 3

Geologic Background of the Picture Gorge Basalt ............................................... 4

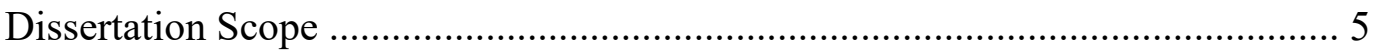

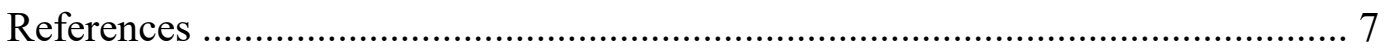

Chapter 1 Geochronology of the Picture Gorge Basalt, Columbia River Flood Basalt

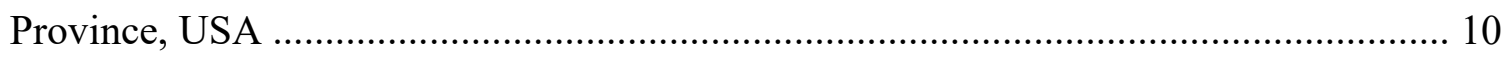

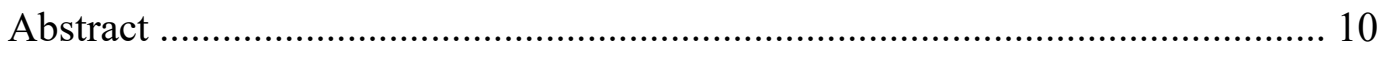

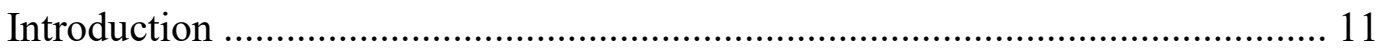

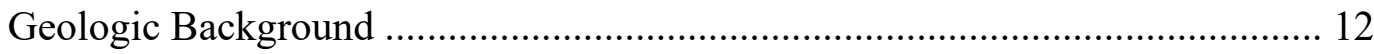

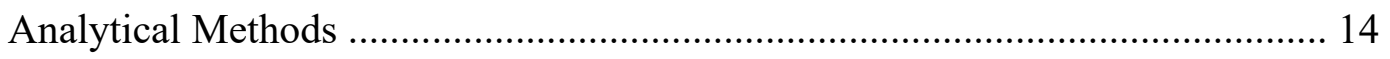

Petrographic Thin Sections ................................................................... 14

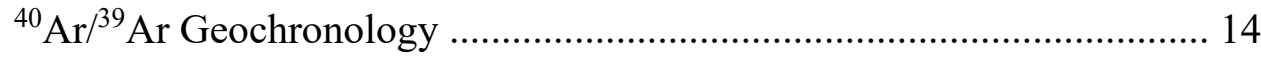

Sample Preparation with a focus on acid leaching …………....... 14

Analytical Procedures .................................................................... 16

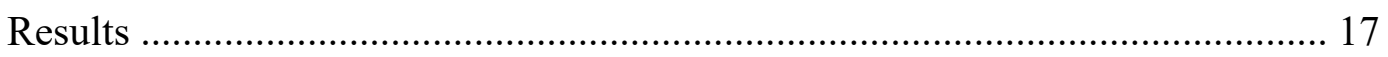

PGB Geochemical Characteristics ...................................................... 17

New Picture Gorge Basalt ages ............................................................. 19 


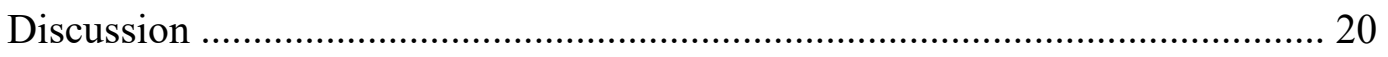

Footprint of Initiation for CRBG Eruptions ……………….................... 20

Implications for Tapping the Mantle ………………………………..... 21

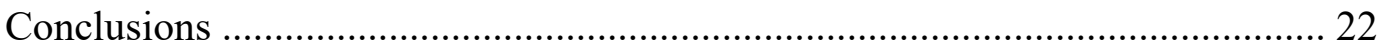

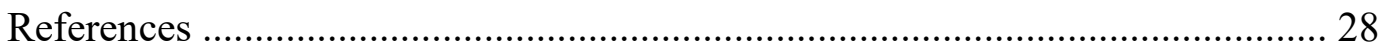

Chapter 2 Reassessment of the Spatial Distribution and Eruptive Volume of the Picture

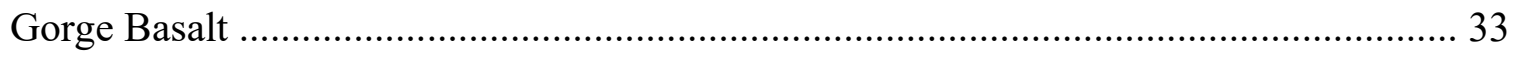

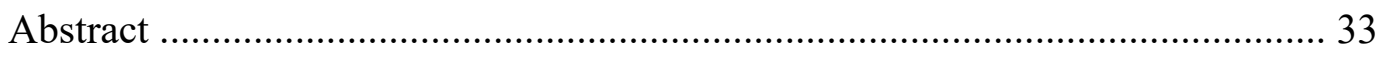

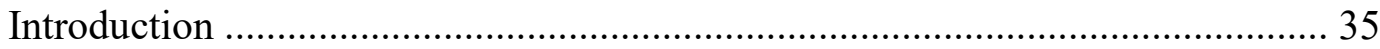

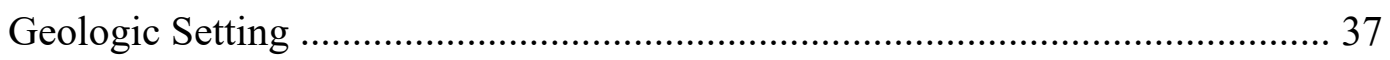

Main-Phase Lavas of the Columbia River Basalt Group ......................... 37

PGB Stratigraphy and Geochemistry .................................................... 38

Basalt of Malheur Gorge ................................................................... 40

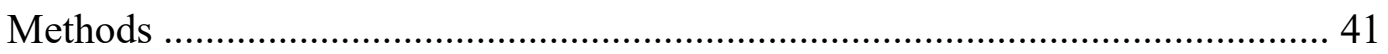

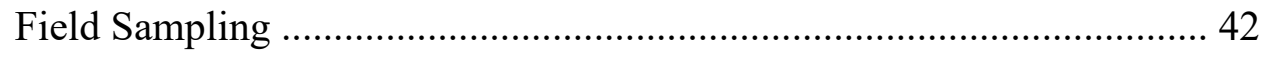

Major and Trace Element Compositions ............................................... 42

Statistical Comparison via Principal Component Analysis ...................... 43

Area and Volume Calculations ............................................................. 45

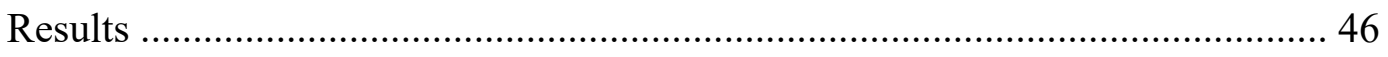

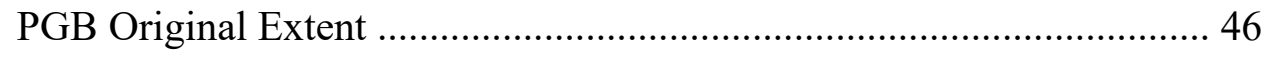

Correlating Samples with PGB Stratigraphy ................................. 46

Stratigraphy in Context of New Ar/Ar Ages ............................... 48

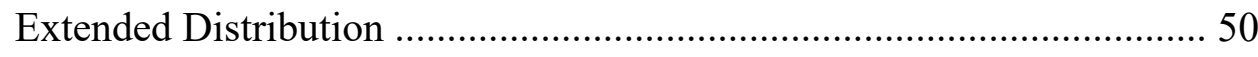

PGB: Compositional Variability and Contrast to other Main Phase

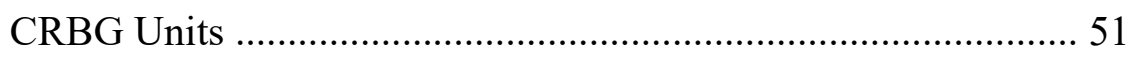

Locations with Lavas of PGB Composition ................................ 52

Corridor from John Day to Burns, Oregon ....................... 52

Rattlesnake Road ............................................................. 53 
Malheur Gorge and Castle Rock area ............................... 54

PGB extent in northeast Oregon ........................................ 56

Hart Mountain to Succor Creek ………………………..... 57

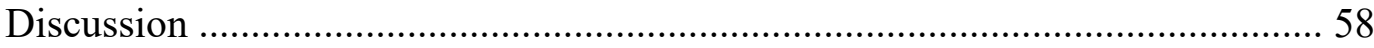

Placing Basalts of Extended Distribution into the PGB Stratigraphy ...... 58

Basalt of Malheur Gorge ................................................................. 59

Eruptive Locations: Proximal and Distal ................................................ 60

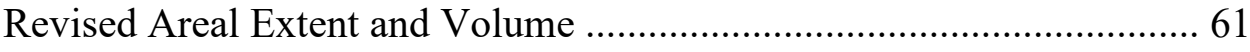

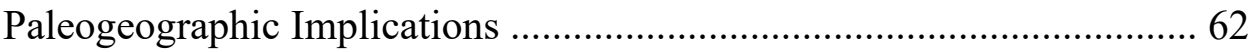

Spatial and Temporal Progression of CRBG Eruptions .......................... 63

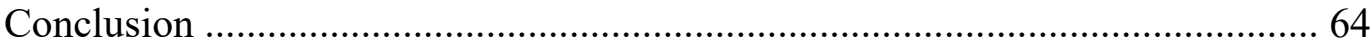

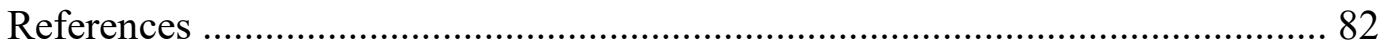

Chapter 3 Mantle Sources and Geochemical Evolution of the Picture Gorge Basalt

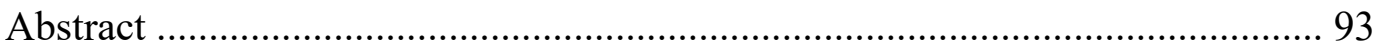

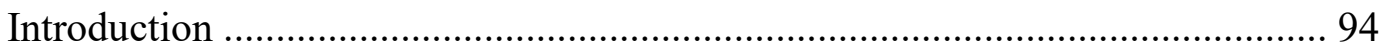

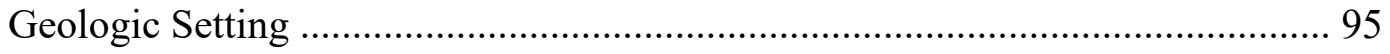

Mantle Components for the CRBG ……………………....................... 95

Geochemical Relationships Between Main-Phase CRBG Formations ... 96

Petrogenetic Significance of Picture Gorge Basalt Stratigraphy ............. 98

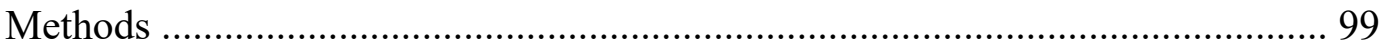

Major and Trace Element Concentrations ................................................. 99

Radiogenic Isotope Analyses ................................................................ 99

Oxygen Isotope Analyses ..................................................................... 103

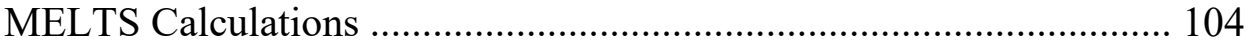

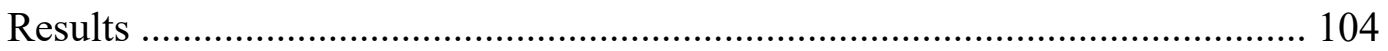

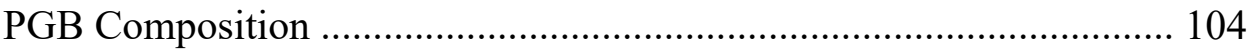

Major and Trace Element Compositions ..................................... 104

Radiogenic and Oxygen Isotope Compositions .......................... 106

Distinguishing Basaltic Lavas and Dikes of the PGB ........................... 107 
Fractionation Models to Account for PGB Geochemical Variability .... 108

Evaluating Crustal Contamination ..................................................... 112

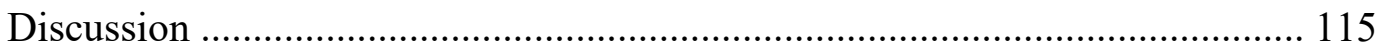

Similarities to Mafic Lavas of the Strawberry Volcanics .................... 115

Evidence of a Contaminated Mantle? .................................................. 117

Parental Magmas and Implication for Mantle Sources ....................... 120

Modification of PGB Magmas ....................................................... 122

Petrogenetic Relationships to Other CRBG Formations ..................... 124

Two Temporal Pulses of Magmatism ............................................. 125

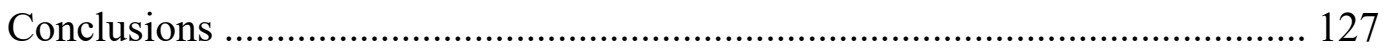

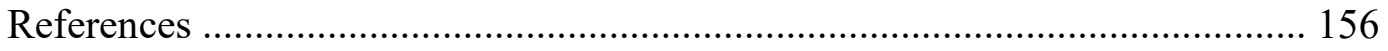

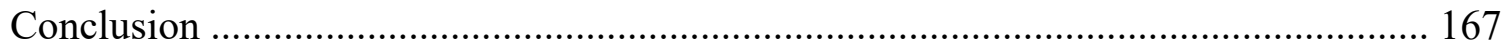

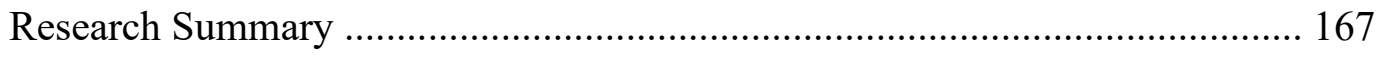

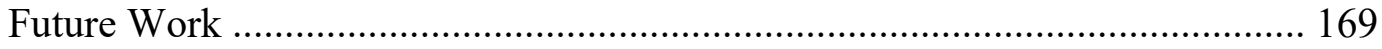

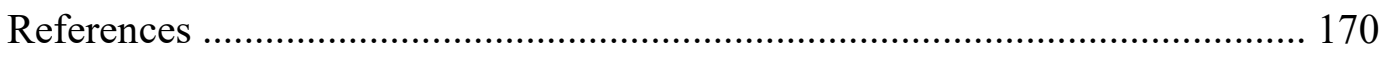

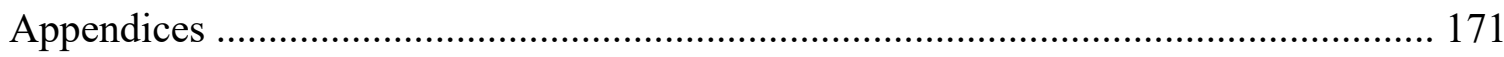

A. Sample Whole Rock (XRF \& ICP-MS) and Location Data ............................ 172

B. $\quad{ }^{40} \mathrm{Ar} /{ }^{39} \mathrm{Ar}$ Age Spectra (Plateaus and Inverse Isochrons) ................................ 173

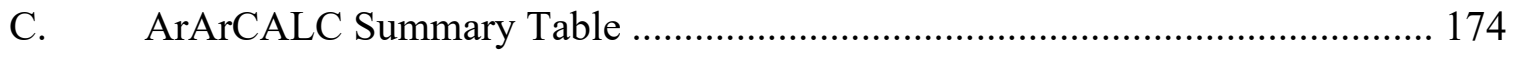

D. Major and Trace Elemental Comparisons of PGB Members …..................... 175

E. Major and Trace Elements versus Mg\# Plots ............................................. 176

F. $\quad \mathrm{Sr}, \mathrm{Nd}, \mathrm{Hf}, \mathrm{Pb}$ Isotope Uncertainty and Isobaric Interferences ........................ 177

G. Oxygen Isotope Summary Table ........................................................... 178

H. Summary Table of MELTS Modelling Results Trace Element Calculations ... 179

I. Principal Component Analysis Code ...................................................... 180

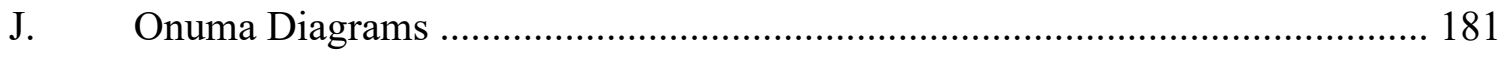




\section{LIST OF TABLES}

\section{CHAPTER 1}

Table 1.1 Summary Table of ${ }^{40} \mathrm{Ar} /{ }^{39} \mathrm{Ar}$ Groundmass Ages for the PGB

\section{CHAPTER 2}

Table 2.1 PGB Subunit Comparison using a Principal Component Analysis of

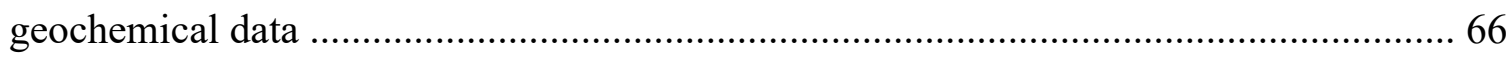

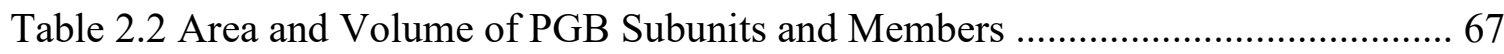

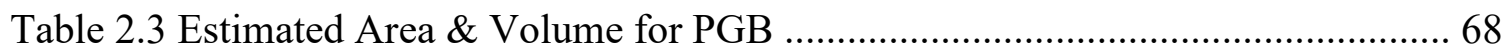

\section{CHAPTER 3}

Table 3.1 Partition Coefficients Used in Trace Element Calculations .......................... 129

Table 3.2 Summary of PGB Primitive Endmember Samples ...................................... 130

Table $3.3 \mathrm{Sr}, \mathrm{Nd}, \mathrm{Hf}, \mathrm{Pb}$, and $\delta^{18} \mathrm{O}$ Isotopic Compositions for the PGB ...................... 131 


\section{LIST OF FIGURES}

\section{CHAPTER 1}

Figure 1.1 Regional map and schematic stratigraphy for the CRBG 25

Figure 1.2 Geochemistry of the PGB compared to main-phase units of the CRBG ...... 26

Figure 1.3 Revised stratigraphic column for new PGB ages ................................... 27

\section{CHAPTER 2}

Figure 2.1 Regional map of the CRBG with locations for new PGB locations 69

Figure 2.2 Stratigraphy of main-phase CRBG with PGB subunits and members 70

Figure 2.3 Geochemistry of PGB members …................................................ 71

Figure 2.4 Regional Map of Malheur Gorge ...................................................... 72

Figure 2.5 Distribution of basaltic lavas south of the type locality of Picture Gorge and the John Day Valley 73

Figure 2.6 Kentucky Butte stratigraphic section and geochemistry of PGB members ... 74

Figure 2.7 Fence diagram of PGB sections and subunit correlation 75

Figure 2.8 Samples of added PGB distribution relative to PGB subunits 76

Figure 2.9 Geochemistry of PGB samples relative to all main-phase CRBG 77

Figure 2.10 Malheur Gorge Transects at Pole Creek and Horseshoe Bend 78

Figure 2.11 Main-phase CRBG geochemistry and multiple PGB samples highlighted from specific locations in the extended distribution 79 
Figure 2.12 Geochemical comparison of lower and upper Pole Creek basalt and main-

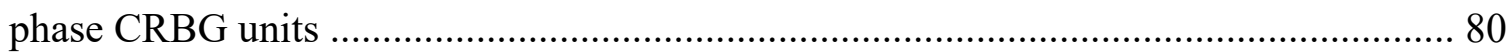

Figure 2.13 Extended distribution map of PGB and geochemical correlation of samples to PGB subunits 81

\section{CHAPTER 3}

Figure 3.1 Regional Map of lavas and dikes of the CRBG Province

Figure 3.2 Major and trace elements for PGB of the original and extended distribution relative to main-phase $\mathrm{CRBG}$

Figure 3.3 CI-Chondrite normalized rare earth element diagram of main-phase CRBG and basalts of the Strawberry Volcanics

Figure 3.4 Stratigraphic section of CRBG and PGB highlighting geochemical differences within PGB subunits

Figure $3.5{ }^{87} \mathrm{Sr} /{ }^{86} \mathrm{Sr}$ Isotopes versus $\mathrm{SiO}_{2}$ (wt.\%), Mg\#, Epsilon $\mathrm{Nd}$, and $\delta^{18} \mathrm{O}$ 136

Figure 3.6 Isotopic and trace element variations in the PGB

Figure 3.7 $\mathrm{Sr}, \mathrm{Nd}$, and $\mathrm{Pb}$ isotope variations in the PGB with mantle components 138

Figure 3.8 Geochemical variability of PGB in the original and extended distribution compared to PGB Subunits

Figure 3.9 Histogram of Oxygen Isotope Compositions for PGB relative to all CRBG formations

Figure 3.10 MELTS modeling results of major elements 141

Figure 3.11 MELTS modeling results of select trace elements 143 
Figure 3.12 MELTS modeling results of select major and trace element ratios

Figure 3.13 Fractionation models of HMD and RR endmember compositions

Figure $3.14 \mathrm{~K} / \mathrm{Ti}$ and $\mathrm{K} / \mathrm{P}$ versus longitude for samples of PGB, Cretaceous Plutons, and Izee metasedimentary rocks 148

Figure 3.15 Location map of accreted terranes in eastern Oregon 149

Figure 3.16 Ba/Th versus $\mathrm{La} / \mathrm{Sm}$ (mantle-normalized) for samples of PGB and Izee metasediments 150

Figure 3.17 Mixing models of PGB primitive group compositions with Izee metasediments 151

Figure 3.18 Spatial transition of PGB lavas to basalts of the Strawberry Volcanics .... 152

Figure $3.19 \delta^{18} \mathrm{O}$ versus ${ }^{87} \mathrm{Sr} /{ }^{86} \mathrm{Sr}$ ratios for the Picture Gorge Basalt 153

Figure 3.20 Histogram of Picture Gorge Basalt and CRBG ages 154

Figure 3.21 Age (Ma) versus $\mathrm{TiO}_{2}$ (wt.\%), $\mathrm{Mg} \#, \mathrm{Sc}(\mathrm{ppm}), \mathrm{Ba} / \mathrm{Nb}$, and Epsilon $\mathrm{Nd}$ for dated Picture Gorge Basalt samples 155 


\section{INTRODUCTION}

\section{OVERVIEW}

Continental Flood Basalts (CFB's) are a type of Large Igneous Province (LIP) which produce huge outpourings of basaltic lava and impact not only the geologic record, but the climate and mass extinctions. Over the last decade, there have been significant advances in the precision of laboratory analytical methods and technique that allows us to determine small geochemical and geochronological differences in the magmatic products of such provinces, enabling us to gain insight into the timing, spatial correlation, and chemical evolution within a flood basalt province.

The Columbia River Basalt Group (CRBG) of the Pacific Northwest, USA is the world's youngest and volumetrically smallest CFB. Lavas and dikes of the CRBG erupted approximately 17 Mya, and represent the surface expression of a vast body of magma that connects to the mantle, and currently resides underneath Yellowstone National Park. While decades of detailed field and laboratory work have added to our understanding of age, geochemical evolution, and spatial distribution and volume of these basalts - there are still outstanding questions. How large was the initial magmatic footprint for CRBG eruptions? Did the main-phase of eruptive activity occur in under 1 million years? What is the petrogenetic relationship between different main-phase formations of the CRBG? And are geochemical mantle components spatially dispersed or localized? Answers to these questions and more aid in understanding mantle components and magmatic processes during eruptions of flood basalts. 


\section{RESEARCH OBJECTIVES}

During eruptions of CFB's, the majority of lava erupts during the first million years, or "main-phase" of activity, although volcanism will continue over millions of years (Coffin and Eldholm, 1994). Within the CRBG, basalts erupted during this mainphase period are grouped into formations based on timing of eruptions, geochemical signatures, and spatial distribution of lavas and dikes (Camp and Ross, 2004). These formations include the Steens, Imnaha, Grande Ronde, and Picture Gorge Basalts (PGB) (e.g. Reidel et al., 2013). Due to apparent limited spatial distribution and eruptive location closest to the Cascade volcanic arc, the PGB has not been considered a critical piece in understanding the overall petrogenetic evolution of this flood basalt province. Furthermore, the PGB is the only formation of the CRBG which has not been dated using ${ }^{40} \mathrm{Ar} /{ }^{39} \mathrm{Ar}$ techniques.

This study combines field and laboratory methodologies with extensive fieldwork spanning five summer seasons, whole-rock geochemical analyses, geochronology, radiogenic and oxygen isotope ratios, and thermodynamic modelling. These coupling of these methods provides new and detailed information regarding the timing, spatial extent and eruptive volume, and petrogenetic processes surrounding emplacement of the PGB formation of the CRBG. To better understand the distribution of tapped mantle components in flood basalt provinces - I use basaltic lavas and dikes of the PGB to answer specific questions regarding eruption longevity, spatial location, and geochemical signatures in erupted basalts. Proposal objectives are distilled from the following questions:

I. When did eruptions of PGB initiate? 
II. For how long did PGB eruptions occur?

III. What is the spatial distribution and volume of PGB lavas and dikes?

IV. Is there a systematic relationship between geochemical signatures and spatial location?

V. How many mantle sources produced the bulk of PGB magmas?

\section{CONTINENTAL FLOOD BASALTS}

Eruptions of LIP' represent the largest flux of volcanic material on Earth and encompass magmatism occurring through both continental and oceanic crust, although CFB's are often the most accessible. Eruptive products of CFB's include pyroclastic rocks, lava flows, dikes and sills, and are distributed over areas greater than 100,000 $\mathrm{km}^{2}$ (Coffin and Eldholm, 1994; Ernst et al., 2005). These eruptive events occur as vast outpourings of basaltic lavas and interpreted to form as a result of buoyant mantle plumes rising from the deep or mid mantle, a topic that is still heavily debated. The impingement of these plumes with continental lithosphere can result in crustal uplift and associated stretching followed by voluminous eruptions of basaltic lava through fissures in the crust (Wilson, 2007). Studying these provinces can help illuminate plume dynamics and mantle components that contribute to their formation.

The CRBG of the Pacific Northwest is the world's youngest continental flood basalt. These tholeiitic basalts erupted from fissures in a back-arc region behind the Cascade arc to the west. They cover an area of 210,000 km2 across Washington's Columbia Basin to the north and the Oregon Plateau to the south, and unconformably overlie Paleozoic to Mesozoic accreted terranes, Cretaceous plutonic rocks, and 
Paleogene volcanic and volcaniclastic rocks (Camp et al., 2017).

The accreted terrane material poses difficulties when attempting to untangle petrogenetic processes within the CRBG. This is because basaltic magmas traversed crustal rocks which provide minimal to no isotopic leverage compared to the geochemical effects on a basaltic magma derived from a depleted mantle source and contaminated by melt from ancient subcontinental lithosphere (Glazner and Farmer 1992). Furthermore, the distinction between crustal contamination versus mantle heterogeneity and chemical variation of basaltic melts is exceedingly challenging, and often requires detailed geochronological work, field observations, and geochemical data (Glazner and Farmer, 1992).

\section{GEOLOGIC BACKGROUND OF THE PICTURE GORGE BASALT}

In 1901 Merriam correlated basaltic lava flows at Picture Gorge with the previously established "Columbia Lavas". The first reference to the name Picture Gorge Basalt (PGB) was by Waters (1961) who distinguished PGB and the Yakima Basalt as the main subunits of the CRBG. Lavas of PGB composition erupted from northnorthwest trending feeder dikes of the Monument dike swarm, and mapped and described through the John Day Valley, central Oregon (Wilcox and Fisher, 1966; Brown and Thayer, 1966; Baldwin, 1973; Bentley and Cockerham, 1973; Nathan and Fruchter, 1974; Robinson, 1975; Fruchter and Baldwin, 1975, Bailey, 1989).

Previous geochronological studies of PGB determined an eruptive period during main-phase CRBG volcanism, but there is no temporal constraint on initiation or duration. These studies were conducted using K-Ar, and although these ages have been 
revisited, workers have concluded an eruptive period similar to the earliest Grande Ronde Basalt (Watkins and Baksi, 1973; Barry et al., 2013; Reidel et al., 2013). Furthermore, samples used for geochronological analyses are spatially restricted to the type locality at Picture Gorge, Oregon. This is because the previously spatial distribution for PGB lavas is relatively restricted this region; as are all samples used for petrogenetic studies. Based on existing geochronological and geochemical data, PGB magmas are interpreted to be the result of tapping a subduction overprinted back-arc mantle, unrelated to a mantle plume (Wolff et al., 2008). It is undetermined whether PGB magmas originated from a petrogenetically distinct mantle source versus one that fed the other main-phase CRBG units (Wolff et al, 2008). Based on these ages, limited apparent distribution, and relatively depleted geochemical signatures, the PGB was not considered a pivotal component in unraveling the eruptive timeline of this flood basalt province.

\section{DISSERTATION SCOPE}

The work presented in this dissertation is organized into three chapters that highlight the timing, spatial extent, and geochemical evolution of the PGB. The outlined approach is multifaceted and will combine field and laboratory methods. Detailed analytical work includes whole-rock major and trace elements via X-ray fluorescence (XRF) and ionically coupled plasma mass spectrometry (ICP-MS), ${ }^{40} \mathrm{Ar} /{ }^{39} \mathrm{Ar}$ geochronology, statistical modeling of geochemical data, fractionation modeling via MELTS, oxygen isotope ratios, and radiogenic ( $\mathrm{Sr}, \mathrm{Nd}, \mathrm{Hf}, \mathrm{\&} \mathrm{Pb}$ ) isotope analyses. The objective of each chapter is chapter is outlined here.

Objective Chapter 1 - Determine timing of PGB eruptions within the CRBG 
province. Specific basaltic dikes and flows of PGB composition were dated to better understand emplacement times and relationship to other CRBG units. In the field, some PGB lavas are capped by the Dinner Creek Tuff, which provides stratigraphic age control. Coupling these stratigraphic relationships with resulting ages provides a more robust placement of PGB eruptions into the existing CRBG stratigraphy. This objective aims to document the full range of PGB ages, and samples will be selected based on field observations and geochemistry.

Objective Chapter 2 - Determine spatial extent and volume of PGB lavas and dikes. This research objective targets dikes and lava flows with PGB composition in locations that are presently not associated with the PGB formation. Lava flows will be targeted in the field based on their stratigraphic relationship to the 16.16 Ma Dinner Creek Tuff (Streck et al., 2015). These samples will then be evaluated with age data, geochemical data of previously identified PGB lavas, and placed into the previously established stratigraphy of PGB.

Objective Chapter 3 - Identify primitive endmember compositions with the PGB and evaluate their petrogenesis. The goal of this research objective is to revisit the idea that magmas that fed PGB eruptions are sourced from a depleted back-arc mantle overprinted by subduction-derived fluids. Primitive endmember compositions will be identified in geochemical space and subsequently modeled using MELTS software. Results will be evaluated against major and trace element data, oxygen isotope data, and radiogenic isotope data for multiple PGB samples. I aim to distinguish geochemical differences which are a result of mantle source heterogeneities versus evolution from modification processes to better understand mantle source components. 
The following chapters are presented as stand-alone manuscripts intended for publication in scientific journals. However, because chapters are presented together in the context of this dissertation, there are references back to figures and/or tables included with earlier chapters. Chapter 1 has been published in Geology, and one of the dated outcrops presented in the journal also earned the cover photograph of the publication. Chapter 2 and 3 are intended for publication following submission of the dissertation. The final conclusion chapter summarizes the major findings of this research and highlights focuses of future work.

\section{REFERENCES}

Bailey, M.M., 1989. Revisions to stratigraphic nomenclature of the Picture Gorge basalt subgroup, Columbia River basalt group. Volcanism and tectonism in the Columbia River flood-basalt province: Geological Society of America Special Paper, 239, pp.67-84.

Baldwin, E.M., 1973. Geology and mineral resources of Coos County, Oregon (Vol. 80). Barry, T.L., Kelley, S.P., Reidel, S.P., Camp, V.E., Self, S., Jarboe, N.A., Duncan, R.A., Renne, P.R., Ross, M.E. and Wolff, J.A., 2013. Eruption chronology of the Columbia River Basalt Group. The Columbia River Flood Basalt Province: Geological Society of America Special Paper, 497, pp.45-66.

Bentley, R. D., and Cockerham, R. S., 1973, The stratigraphy of the Picture Gorge Basalt (PGB), north-central Oregon: Geol. Soc. America, Abs. with Programs (Cordilleran Sec.), v. 5 , no. 1, p. 9 . 
Brandon, A.D., Hooper, P.R., Goles, G.G. and Lambert, R.S.J., 1993. Evaluating crustal contamination in continental basalts: the isotopic composition of the Picture Gorge Basalt of the Columbia River Basalt Group. Contributions to Mineralogy and Petrology, 114(4), pp.452-464.

Brown, C.E. and Thayer, T.P., 1966. Geologic map of the Canyon City quadrangle, northeastern Oregon. US Geological Survey.

Carlson, R.W., 1984, Isotopic constraints on Columbia River flood basalt genesis and the nature of the subcontinental mantle. Geochimica et Cosmochimica Acta, v. 48, p. 2357-2372.

Camp, V.E., Ross, M.E., Duncan, R.A., Jarboe, N.A., Coe, R.S., Hanan, B.B. and Johnson, J.A., 2013. The Steens basalt: Earliest lavas of the Columbia River basalt group. Geological Society of America Special Papers, 497, pp.87-116.

Camp, V.E., Ross, M.E., Duncan, R.A. and Kimbrough, D.L., 2017. Uplift, rupture, and rollback of the Farallon slab reflected in volcanic perturbations along the Yellowstone adakite hot spot track. Journal of Geophysical Research: Solid Earth. Coffin, M.F., and Eldholm, O., 1994, Large igneous provinces: Crustal structure, dimensions, and external consequences: Reviews of Geophysics, v. 32, p. 1-36.

Ernst, R.E., Buchan, K.L. and Campbell, I.H., 2005. Frontiers in large igneous province research. Lithos, 79(3-4), p.271-297.

Merriam, J. C., 1901, A contribution to the geology of the John Day basin: California Univ. Dept. Geol. Sci. Bull., v. 2, p. 269-314.

Nathan, S., and Fruchter, J. S., 1974, Geochemical and paleomagnetic stratigraphy of the Columbia River Group in central Oregon with particular reference to the relationship 
between the Picture Gorge and Yakima basalts: Geol. Soc. America Bull., v. 85, p. 63-76.

Reidel, S.P., Camp, V.E., Tolan, T.L. and Martin, B.S., 2013, The Columbia River flood basalt province: Stratigraphy, areal extent, volume, and physical volcanology, in Geological Society of America Special Paper, 497, p. 1-43.

Robinson, P.T., 1975, Reconnaissance geologic map of the John Day Formation in the southwestern part of the Blue Mountains and adjacent areas, north-central Oregon: U.S. Geological Survey Miscellaneous Geologic Investigations Map 1-872, scale 1:125,000.

Streck, M.J., Ferns, M.L. and McIntosh, W., 2015. Large, persistent rhyolitic magma reservoirs above Columbia River Basalt storage sites: The Dinner Creek Tuff Eruptive Center, eastern Oregon. Geosphere, 11(2), pp.226-235.

Wilcox, R. E., and Fisher, R. V., 1966, Geologic map of the Monument quadrangle, Grant County, Oregon: U.S. Geol. Survey Geol. Quad. Map GQ-541.

Wilson, B.M., 2007. Igneous petrogenesis a global tectonic approach. Springer Science \& Business Media.

Wolff, J.A., Ramos, F.C., Hart, G.L., Patterson, J.D. and Brandon, A.D., 2008. Columbia River flood basalts from a centralized crustal magmatic system. Nature Geoscience, 1(3), pp.177-180.

Wolff, J.A. and Ramos, F.C., 2013. Source materials for the main phase of the Columbia River Basalt Group: Geochemical evidence and implications for magma storage and transport. Geological Society of America Special Papers, 497, pp.273-291. 


\title{
CHAPTER 1
}

\section{GEOCHRONOLOGY OF THE PICTURE GORGE BASALT, COLUMBIA RIVER FLOOD BASALT PROVINCE, USA}

Cahoon, E.B., Streck, M.J., Koppers, A.A.P. and Miggins, D.P., 2020. Reshuffling the Columbia River Basalt chronology — Picture Gorge Basalt, the earliest-and longesterupting formation. Geology, 48(4), pp.348-352.

\begin{abstract}
The Columbia River Basalt Group (CRBG) is the youngest continental flood basalt province, presumably sourced from the deep-seated plume that currently resides underneath Yellowstone National Park. The earliest erupted basalts from this province aid in understanding and modeling plume impingement and subsequent evolution of basaltic volcanism. We explore the Picture Gorge Basalt (PGB) formation of the CRBG, and discuss the location and geochemical significance in a temporal context of early CRBG magmatism.
\end{abstract}

We report new ARGUS-VI multicollector ${ }^{40} \mathrm{Ar} /{ }^{39} \mathrm{Ar}$ incremental heating ages from known PGB localities and additional outcrops that we can geochemically classify as the PGB. These ${ }^{40} \mathrm{Ar} /{ }^{39} \mathrm{Ar}$ ages range between $17.23 \pm 0.04$ and $16.06 \pm 0.14 \mathrm{Ma}$, indicating the PGB erupted earlier and longer than other CRBG main-phase units. These ages illustrate that volcanism initiated over a broad area in the center of the province, and the geochemistry of these early lavas reflects a mantle source that is distinct both spatially and temporally. Combining ages with the strongest arc-like (but depleted) geochemical signal of PGB among CRBG units indicates the shallowest metasomatized 
back arc-like mantle was tapped first and concurrently, with later units (Steens, Imnaha) showing increased influence of a plume like source.

\section{INTRODUCTION}

The Columbia River Basalt Group (CRBG) of the Pacific Northwest, USA, is the world's youngest flood basalt and has played an important role in understanding the dynamics of large igneous provinces (LIP). Flood basalts are a type of LIP representing the most voluminous periods of volcanic activity on earth, often coinciding with times of environmental crisis. While flood basalt provinces can be active for millions of years, the majority of lava erupts during the first million years, or "main-phase" of activity (Coffin and Eldholm, 1994). This main-phase period is thought to represent impingement of the mantle plume head with the lithosphere (Ernst et al., 2005).

Continental flood basalt provinces are composed of pyroclastic rocks, lava flows, dikes and sills, and cover extensive areas $>100,000 \mathrm{~km}^{2}$ (Coffin and Eldholm, 1994; Ernst et al., 2005). The location of the mantle plume and its temporal development are evaluated based on age and distribution patterns of lavas and dike swarms thought to represent the feeder systems to the surficial eruption sites. However, large volumes of these basaltic magmas can travel 100's of km's subaerially and within dike and sill complexes, illustrating that even the location of dike swarms is not a conclusive indication of where magmatism originated (Ernst and Buchanan, 1997; Ernst et al., 2019).

As basaltic magmas traverse the crust, they are prone to differentiation and contamination processes which may modify the geochemical signals of the mantle source 
in the eruptive products. As flood basalt activity waxes and wanes, these geochemical signals provide evidence for temporal changes in mantle source and/or evidence for interaction with the crust (Peate et al., 2008). Age distribution pattern of basaltic flows and dikes, along with changing chemical signatures, provide key fingerprints of underlying mantle dynamics of flood basalt provinces and the involvement of a deep mantle component.

Main-phase volcanism of the Columbia River Basalt Group (CRBG) occurred between $\sim 16.8-15.9$ million years ago (Ma), and represents an eruptive volume of over $210,000 \mathrm{~km}^{3}$ (Reidel et al., 2013). These basalts are divided into formations based on geographic location of vents, geochemistry, and timing of eruptions (Camp and Ross, 2004) and include the Steens, Imnaha, Grande Ronde, and Picture Gorge Basalts (PGB) (e.g. Reidel et al., 2013). While several models have been proposed for CRBG magmatism, many workers support that the flood basalts are sourced from the Yellowstone mantle plume (e.g. Geist and Richards, 1993; Camp, 1995). Our study investigates plume impingement both spatially and temporally through the lens of the PGB (Fig. 1.1).

\section{GEOLOGIC BACKGROUND}

Geochronological studies on the CRBG and resulting ages have a complicated past, due to accuracy and precision issues (e.g., Baksi, 2013; Barry et al., 2013). CRBG main-phase eruptions were originally hypothesized to have occurred over $\sim 1-2$ million years, but this interval has been revised to $\sim 1.3$ million years, between $\sim 16.9-15.6$ million 
years ago (Ma) (Barry et al., 2013). Recent studies have reduced the interval (Jarboe et al, 2010; Mahood and Benson, 2017) to $\sim 0.56$ million years (Kasbohm and Schoene, 2018) and place the end of main-phase volcanism (i.e. end of Grande Ronde Basalt) at $\sim 16 \mathrm{Ma}$ rather than at 15.6 Ma (cf. Wolff and Ramos, 2013 and references therein).

The only PGB geochronological study was within the type section at Picture Gorge (Fig. 1.1). These K/Ar ages range from 15.9 to $14.7 \mathrm{Ma}$ with uncertainties up to 0.8 Ma (2б) (Watkins and Baksi, 1974), although presumed PGB eruptive activity spans from 16.4 Ma to $15.2 \pm 0.4 \mathrm{Ma}$ (Barry et al., 2013). Using these ages and the magnetic reversal observed in flows at Picture Gorge, it has been inferred that the PGB erupted concurrently with N1 and R2 geomagnetic polarity flows of the Grande Ronde Basalt (Nathan and Frutchter, 1974; Reidel et al., 2013) (Fig. 1.1C).

Recent data on mid-Miocene magnetic reversals highlight inconsistencies with PGB ages. Jarboe et al. (2010) proposed that the older N0-R1 magnetic reversal occurred at $\sim 16.5 \mathrm{Ma}$. This is also supported by constraining the R0-N0 transition to $\sim 16.6 \mathrm{Ma}$ date by sanidine geochronology on interbedded silicic tuffs (Mahood and Benson, 2017), and by high precision U-Pb dating work (Kasbohm and Schoene, 2018). Kasbohm and Schoene (2018) also constrained the later R2-N2 transition to younger than $16.210 \pm$ 0.043/0.048 Ma. Consequently, the N1-R2 transition falls between 16.5 and 16.2 Ma, signifying PGB flows must be older than the published K/Ar ages.

PGB lavas erupted from NNW trending feeder dikes of the Monument Dike swarm in northeastern Oregon (Frutcher and Baldwin, 1975), and are thought to represent only 1.1 percent of all CRBG (Reidel et al., 2013; Barry et al., 2013) (Fig. 1.1A). Geochemical and isotopic data from the known PGB distribution area, led previous 
workers to acknowledge that while comparable to Steens Basalt, the PGB contains a dissimilar mantle source component (Carlson, 1984; Bailey, 1989; Wolff et al., 2008; Wolff and Ramos, 2013).

\section{ANALYTICAL METHODS}

Samples selected for ${ }^{40} \mathrm{Ar} /{ }^{39} \mathrm{Ar}$ dating are from known and newly correlated PGB localities (Fig. 1.2). Preferred eruptive ages (groundmass separates) for all samples are summarized in Table 1. Detailed analytical age spectras are in the appendices B and C.

\section{Petrographic thin sections}

Samples selected for ${ }^{40} \mathrm{Ar} /{ }^{39} \mathrm{Ar}$ analysis first had thin sections made to reduce choosing samples with extensive interstitial alteration which was identified as glass or abundant oxides. Thin sections were prepared for petrographic study by Spectrum Petrographics in Vancouver, WA and Wagner Petrographics in Lindon, UT. Descriptions of these thin sections augment hand specimen identifications and facilitate interpretation of samples to be utilized for ${ }^{40} \mathrm{Ar} /{ }^{39} \mathrm{Ar}$ dating.

\section{${ }^{40} \mathrm{Ar} /{ }^{39} \mathrm{Ar}$ Geochronology}

\section{Sample Preparation with a focus on acid leaching}

Eleven basaltic samples were selected for ${ }^{40} \mathrm{Ar} /{ }^{39} \mathrm{Ar}$ analysis, four of which were analyzed in two separate irradiations. Samples were crushed and sieved to $180-150 \mu \mathrm{m}$ or 250-180 $\mu \mathrm{m}$ depending on the available amount of material. Samples were then run through a Frantz magnetic separator to separate feldspar. Groundmass fractions were then leached in five separate ultrasonic baths of different aqueous solutions, each for approximately one hour. Solutions, in order, included 1M hydrochloric acid, 6M 
hydrochloric acid, $1 \mathrm{M}$ nitric acid, 3M nitric acid, and milli-Q water to remove adhering glass and clay. Samples were then rinsed three times with milli-Q water and dried overnight.

During our first round of experiments, some groundmass samples displayed significant argon recoil, interpreted to be associated with highly altered material and loosely held atmospheric argon based on alteration of glass to clays (Baksi, 1973). Samples affected by recoil do not overlap in error at their lower and higher temperature steps, preventing an age plateau from being resolved. The lower temperature steps on an inverse isochron are discordant and lie to the left of the isochron, which results in a curved isochron, a trademark of recoil. The higher temperature steps affected by recoil often are highly radiogenic making inverse isochrons difficult to determine. The potential for recoil is challenging to identify during sample preparation and experiments result in age data that is not geologically meaningful when considered alone. This issue was addressed during the second round of sample preparation by adding a mild (5\%) hydrofluoric acid (HF) bath for approximately three minutes to groundmass samples following the full suite of a standard groundmass leach. This additional step removed the altered material responsible for the argon recoil but potentially introduced atmospheric argon. Data resulting from these samples leached in hydrofluoric acid are meaningful, as their age plateaus overlapped with the non-hydrofluoric treated fraction at their intermediate temperature heating steps. And, inverse isochrons of the hydrofluoric leached samples, cut through the apex of the ellipsoids on inverse isochron plots from samples that were plagued by argon recoil. All sample ages included in the manuscript text and associated figures are the dates acquired from sample fractions what underwent 
this additional leaching step during sample preparation. By combining the most useful temperature steps from both sample experiments, our data is then spaced out along an inverse isochron, increasing the spreading factor. Some, but not all samples, exhibited a decrease in their $\mathrm{K} / \mathrm{Ca}$ ratios from the non-hydrofluoric leached sample to the hydrofluoric leached sample.

\section{Analytical Procedures}

Fourteen new ${ }^{40} \mathrm{Ar} /{ }^{39} \mathrm{Ar}$ ages (Appendix C) obtained by incremental heating methods using the ARGUS-VI mass spectrometer. Groundmass samples were irradiated for 6 hours (Irradiation 15-OSU-07) in the TRIGA CLICIT nuclear reactor at Oregon State University, along with the FCT sanidine $(28.201 \pm 0.023 \mathrm{Ma}, 1 \sigma)$ flux monitor (Kuiper et al. 2008). Individual J-values for each sample were calculated by parabolic extrapolation of the measured flux gradient against irradiation height and typically give $0.2-0.3 \%$ uncertainties $(1 \sigma)$. The ${ }^{40} \mathrm{Ar}{ }^{39} \mathrm{Ar}$ incremental heating age determinations were performed on a multi-collector ARGUS-VI mass spectrometer at Oregon State University that has 5 Faraday collectors (all fitted with $10^{12} \mathrm{Ohm}$ resistors) and 1 ion-counting $\mathrm{CuBe}$ electron multiplier (located in a position next to the lowest mass Faraday collector). This allows us to measure simultaneously all argon isotopes, with mass 36 on the multiplier and masses 37 through 40 on the four adjacent Faradays. This configuration provides the advantages of running in a full multi-collector mode while measuring the lowest peak (on mass 36) on the highly sensitive electron multiplier (which has an extremely low darknoise and a very high peak/noise ratio). Irradiated samples were loaded into $\mathrm{Cu}$ planchettes in an ultra-high vacuum sample chamber and incrementally heated by scanning a defocused $25 \mathrm{~W} \mathrm{CO}_{2}$ laser beam in preset patterns across the sample, in order 
to release the argon evenly. After heating, reactive gases were cleaned up using an SAES Zr-Al ST101 getter operated at $400^{\circ} \mathrm{C}$ for $\sim 10$ minutes and two SAES Fe-V-Zr ST172 getters operated at $200^{\circ} \mathrm{C}$ and room temperature, respectively. All ages were calculated using the corrected Steiger and Jäger (1977) decay constant of $5.530 \pm 0.097 \times 10^{-10} 1 / \mathrm{yr}$ $(2 \sigma)$ as reported by Min et al. (2000). For all other constants used in the age calculations we refer to Table 2 in Koppers et al. (2003). Incremental heating plateau ages and isochron ages were calculated as weighted means with $1 / \sigma^{2}$ as weighting factor (Taylor 1997) and as YORK2 least-square fits with correlated errors (York 1968) using the ArArCALC v2.6.2 software from Koppers (2002) available from the http://earthref.org/ArArCALC/ website.

Data are reduced for age calculations using the ArArCALC software provided by Koppers (2002) using the currently accepted ${ }^{40} \mathrm{~K}$ decay constant (Steiger and Jäger, 1977). ArArCALC software (Koppers, 2002) was used to reduce the isotopic data and make age calculations. Further details of analytical procedures were described in Duncan and Keller (2004; see also the OSU laboratory website, http://geochronology.coas.oregonstate.edu/)

\section{RESULTS}

\section{PGB Geochemical Characteristics}

Samples selected for geochronology are a subset of all samples collected in this study. We sampled along stratigraphic sections of the known outcrop area of the PGB, age equivalent basalts that are adjacent to known outcrop area (between towns of John Day and Burns, Fig. 1.1), and sections that were previously correlated with other CRBG 
units such as Steens or Imnaha Basalt at Malheur Gorge (Hooper et al., 2002; Camp et al., 2003, 2013).

When compared to all main-phase CRBG units, the PGB is geochemically and isotopically most similar to Steens Basalt (Carlson, 1984; Wolff and Ramos, 2013). PGB samples show a comparable $\mathrm{SiO}_{2}$ range (48.5 to $53 \mathrm{wt. \%}$ ) as Steens and Imnaha Basalt (with $<51 \% \mathrm{SiO}_{2}$ for Rock Creek and $>51 \%$ for American Bar chemical types of Imnaha Basalt, cf. Hooper, 1984), but for a given $\mathrm{SiO}_{2}$ wt.\%, the PGB contains lower Th, high field strength elements (HFSEs), light rare earth elements (LREE), and Zr/Y values (Fig. 2, Supp. D). The only exceptions are a few lowermost Imnaha (American Bar subgroup) flows at Dug Bar, northeastern Oregon (Fig. 1.1) (Swanson et al., 1979) that are distinct from other more typical early Imnaha flow types. Early on, it was noted that these basal flows exhibit PGB-like chemistry [supp. references] but they were not correlated with PGB due to their distance from the type locality (Swanson et al., 1979). Furthermore, PGB samples contain lower $\mathrm{SiO}_{2}$ (wt. \%) and incompatible trace element concentrations than the Grande Ronde Basalt (Fig. 1.2). We use these characteristics to identify basalts with PGB composition and distinguish them from other CRBG units.

As some sample locations are over $100 \mathrm{~km}$ from the nearest currently mapped PGB outcrop, we highlight additional locations in between (e.g. Rattlesnake Rd, Fig. 1.2), where basaltic flows are geochemically identifiable as PGB (Fig. 1.2). All flows and dikes selected for geochronology reflect PGB chemical characteristics with one possible exception of at Pole Creek (CAH16-065). Yet, this sample plots within the PGB field in Figure 1.2A and in additional parameter space (e.g. $\mathrm{Nb}, \mathrm{Rb}$, and $\mathrm{K}_{2} \mathrm{O} / \mathrm{Yb}$ vs. $\mathrm{SiO}_{2}$ ), along 
with other Pole Creek flows that are stratigraphically lower.

\section{New Picture Gorge Basalt ages}

We first examine our oldest samples, which are from the previously mapped distribution of PGB (Brown and Thayer, 1966; Frutcher and Baldwin, 1975; Bailey, 1989). These ages are over $17 \mathrm{Ma}$ and represent PGB basal flows which immediately overlie Oligocene tuffs at the type locality of Picture Gorge (CAH17-245), Holmes Creek (CAH17-222A), and along the North Fork of the John Day River near the town of Dale (CAH17-200) (Fig. 1.1, Table 1.1). These PGB flows are the earliest CRBG (Fig. 1.3) and extend initiation of the CRBG to $17.23 \pm 0.04 \mathrm{Ma}$.

A recent age of $16.97 \pm 0.06 \mathrm{Ma}$ from the base of Steens Mountain, now defined as the Lower A Steens sequence, was the oldest and extended Steens Basalt activity by $200 \mathrm{ka}$ (Moore et al., 2018). We also obtained ages for the PGB just under $17 \mathrm{Ma}$, including an aphyric dike (CAH15-023, AM) exposed at the southern edge of the Monument dike swarm (Frutcher and Baldwin, 1975), and a flow (CAH17-174A, SM) located further south at Snow Mountain (Fig. 1.1, Table 1.1).

The geochemical analyses allow us to extend the magmatic footprint of PGB lavas. South of the main Monument dike swarm and Aldrich Mountains, exposures of mid-Miocene basalt are abundant (i.e. IR, GR, SM, I, and WMB, Fig. 1A) but lack the lateral continuity of flows further north near the type locality (Brown and Thayer, 1966). This is likely the result of the paleo-topography, subsequent erosion, or coverage by the 16.16 Ma Dinner Creek Tuff (unit 1) or younger widespread ignimbrites (e.g. Streck et al., 2015) contributing to why these mid-Miocene basalts were not included in earlier 
PGB map compilations, despite overlap with the southern Monument dike swarm. Our youngest age (16.06 $\pm 0.14 \mathrm{Ma})$ came from one of these dikes (GR, Fig. 1.1), and suggests PGB volcanism lasted over 1 million years, longer than any other CRBG mainphase unit.

Dated flows at locations previously correlated with Steens Basalt include Pole Creek in Malheur Gorge, and Castle Rock (PC and CR, Fig. 1.1). Our PGB sample at Castle Rock (MC-76-16, CR) yields an age of 16.23 \pm 0.09 Ma, consistent with exposure of the 16.16 Ma Dinner Creek Tuff unit 1 above. At Pole Creek, our dated PGB flow (CAH16-065, PC) directly underlies Grande Ronde Basalt and yields an age of $16.72 \pm$ $0.03 \mathrm{Ma}$ (Table 1.1., Appendix B). This age fits within age relationships of Camp et al. (2003), but is not within $2 \sigma$ uncertainty of a younger Steens Basalt plagioclase age in Pole Creek (16.45 $\pm 0.11 \mathrm{Ma}, 1 \sigma$; Jarboe et al, 2010). While this plagioclase-phyric flow is interpreted to be the base of the Pole Creek section, it is not in direct stratigraphic continuity with our section where PGB represents the lowest stratigraphic exposures.

\section{DISCUSSION}

\section{Footprint of Initiation for CRBG Eruptions}

Our new PGB ${ }^{40} \mathrm{Ar} /{ }^{39} \mathrm{Ar}$ ages indicate an earlier and longer eruptive phase compared to other main-phase units (Fig. 1.3). Our earliest PGB ages are slightly older than Steens and Imnaha Basalt, which initiated at $16.97 \pm 0.06 \mathrm{Ma}$ and $16.637 \pm 0.08 \mathrm{Ma}$, respectively (Moore et al., 2018; Kasbohm and Schoene, 2018).

PGB flows that are most distal to the previously known distribution near the Monument dike swarm, are located in Malheur Gorge at the Pole Creek and the Castle 
Rock locations (Fig. 1.1). There, the previous CRBG stratigraphy included Steens, Imnaha, and Grande Ronde Basalt (Hooper et al., 2002; Camp et al., 2003); now, we also identify PGB flows, which are capped by Grande Ronde Basalt.

Our older and overlapping ages of PGB as compared to the oldest ages of Steens Basalt, could result from a rapidly spreading plume head, not confined to Steens Mountain. This is consistent with large scale geological and geophysical features that converge $\sim 150 \mathrm{~km}$ east of the Monument dike swarm, potentially induced by stress imposed on the base of crust due to inception of the Yellowstone plume (Glen and Ponce, 2002).

While mantle plume models illustrate that volcanism is most intense above plume tails (e.g. Morgan, 1981; Hill et al., 1992), the outward spreading of the plume at the base of the lithosphere can result in volcanism over a much wider extent, i.e. several hundred kilometers (e.g. Ernst et al., 2019 and references therein). In conjunction with an emerging new age distribution pattern for co-genetic CRBG rhyolites (Streck et al., 2017; Webb et al, 2018), our PGB ages and locations suggest earliest volcanism due to plume impingement occurred over a broad region, from Steens Mountain at the southern portion of the province, further north to the Monument dike swarm (Fig. 1.1).

\section{Implications for Tapping the Mantle}

The PGB contains geochemical features which distinguish it from other CRBG main-phase units. The most notable are elevated ratios of large ion lithophile elements (LILEs) to HFSEs, the fingerprint of a subduction modified mantle (Fig. 1.2) and the 
basis for arguing that PGB likely contains a backarc mantle component (Carlson, 1984; Wolff and Ramos, 2013). While this feature is present in all CRBG subunits, it is the most prevalent in PGB and has new significance in light of our ages, the tapping of an evolving geochemical signal.

We propose the initial pulse of PGB, and thus CRBG magmatism, was sourced from a shallower back-arc-like mantle source, with a plume-like mantle progressively playing a greater role over time. Yet with PGB and Steens Basalt erupting nearly contemporaneously, the variation in geochemical traits might not reflect a solely temporal feature, but also a spatial characteristic that we are still detailing. Spatial and temporal geochemical zonation have been observed in other mantle plume systems (Hoernle et al., 2015 and references therein). This geochemical signal may extend east of the Wallowa Mountains to Dug Bar (Fig. 1.1A), if early basalt flows with PGB-like chemistry erupted locally instead of traveling great distances (Fig. 1.2).

\section{CONCLUSIONS}

We report the first ${ }^{40} \mathrm{Ar} /{ }^{39} \mathrm{Ar}$ ages for the Picture Gorge Basalt (PGB), which range between $17.23 \pm 0.04$ and 16.06 \pm 0.14 Ma. Ages demonstrate the PGB erupted earlier and longer than other CRBG main-phase unit, and CRBG volcanism initiated over a broad region that includes Picture Gorge. Our study also identifies outcrops of PGB beyond its currently published extent and necessitates increasing distribution and ultimately eruptive volume of the PGB. 
Combining ages with the strongest arc-like but depleted geochemical signal of the PGB among CRBG units, illustrates that the shallowest metasomatized back arc-like mantle was tapped first and concurrently, with later CRBG (Steens, Imnaha) that exhibit an increased influence of a plume-like source. This newly identified temporal and spatial geochemical signal provides an added constraint for CRBG evolution models. 


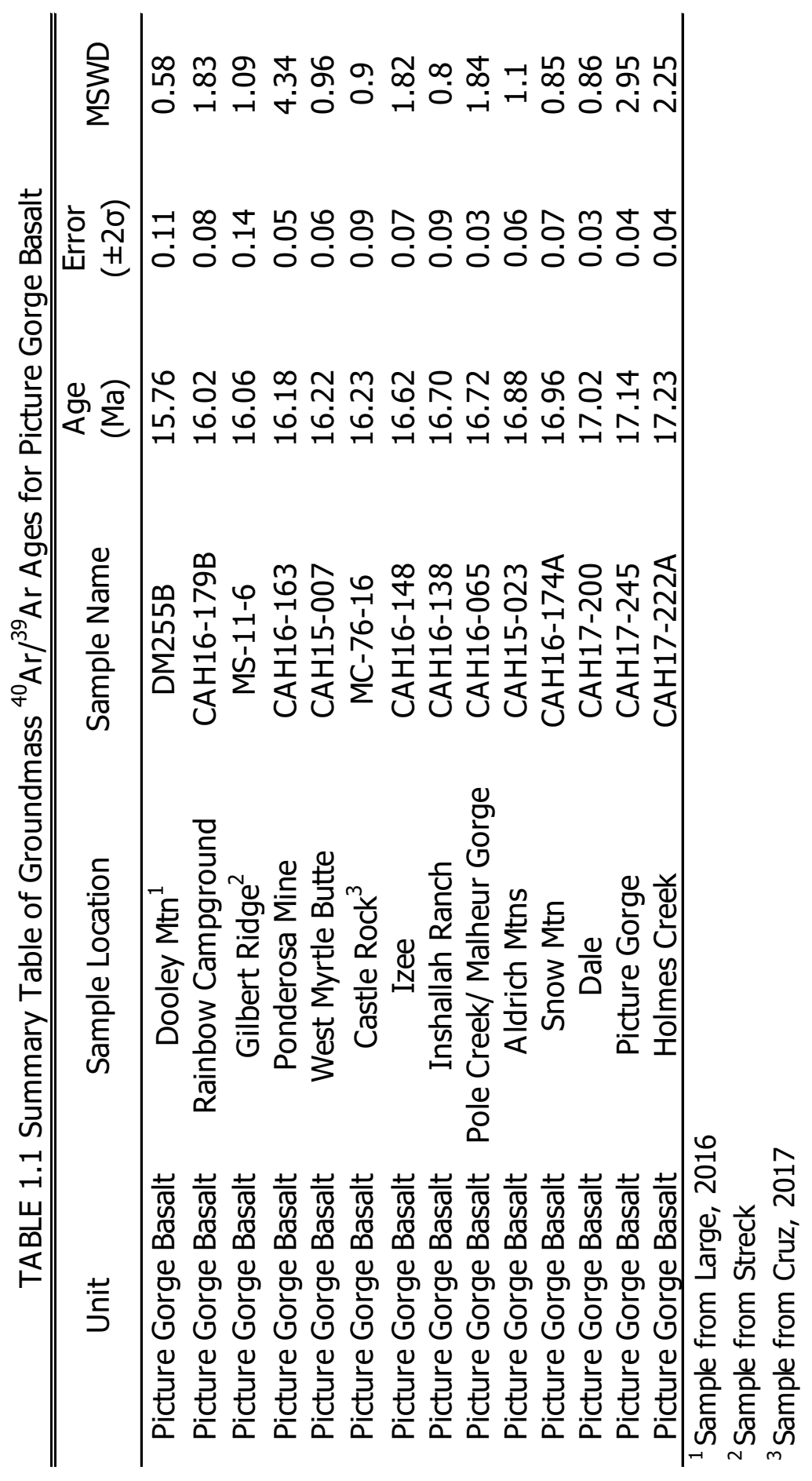




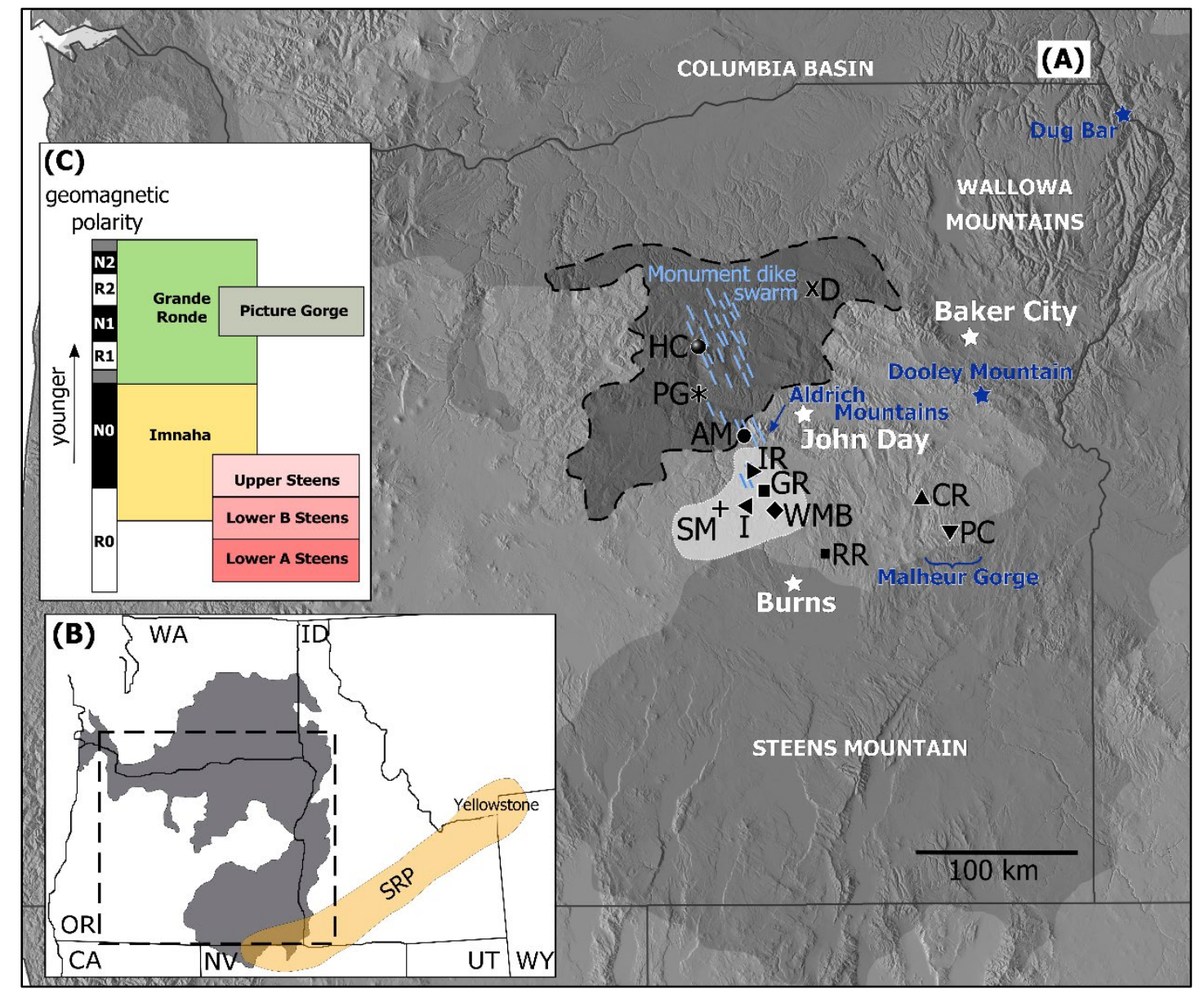

Figure 1.1 (A) Current distribution of the Columbia River Basalt Group (CRBG, northwestern United States) (gray), the original extent of the Picture Gorge Basalt (PGB) (dark gray, black dashed outline), our added PGB extent (shaded white region), and locations of dated PGB samples: Gilbert Ridge (GR), West Myrtle Butte (WMB), Snow Mountain (SM), town of Dale (D), Picture Gorge (PG), Holmes Creek (HC), town of Izee (I), Aldrich Mountains (AM), Inshallah Ranch (IR), Pole Creek in Malheur Gorge (PC), Castle Rock (CR) north of the Malheur Gorge, and Rattlesnake Road, undated (RR). Monument dike swarm locations after Brown \& Thayer (1966). (B) Overview map with CRBG extent (gray), current location of the Yellowstone plume, and presumed hot-spot track (orange) along the Snake River Plain (SRP). Box shows extent of Panel A. WA-Washington; ID-Idaho; OROregon; CA-California; NV-Nevada; UT-Utah; WY-Wyoming. Extent of main map is outlined with dashed line. (C) Stratigraphy and geomagnetic polarity of main-phase CRBG. 

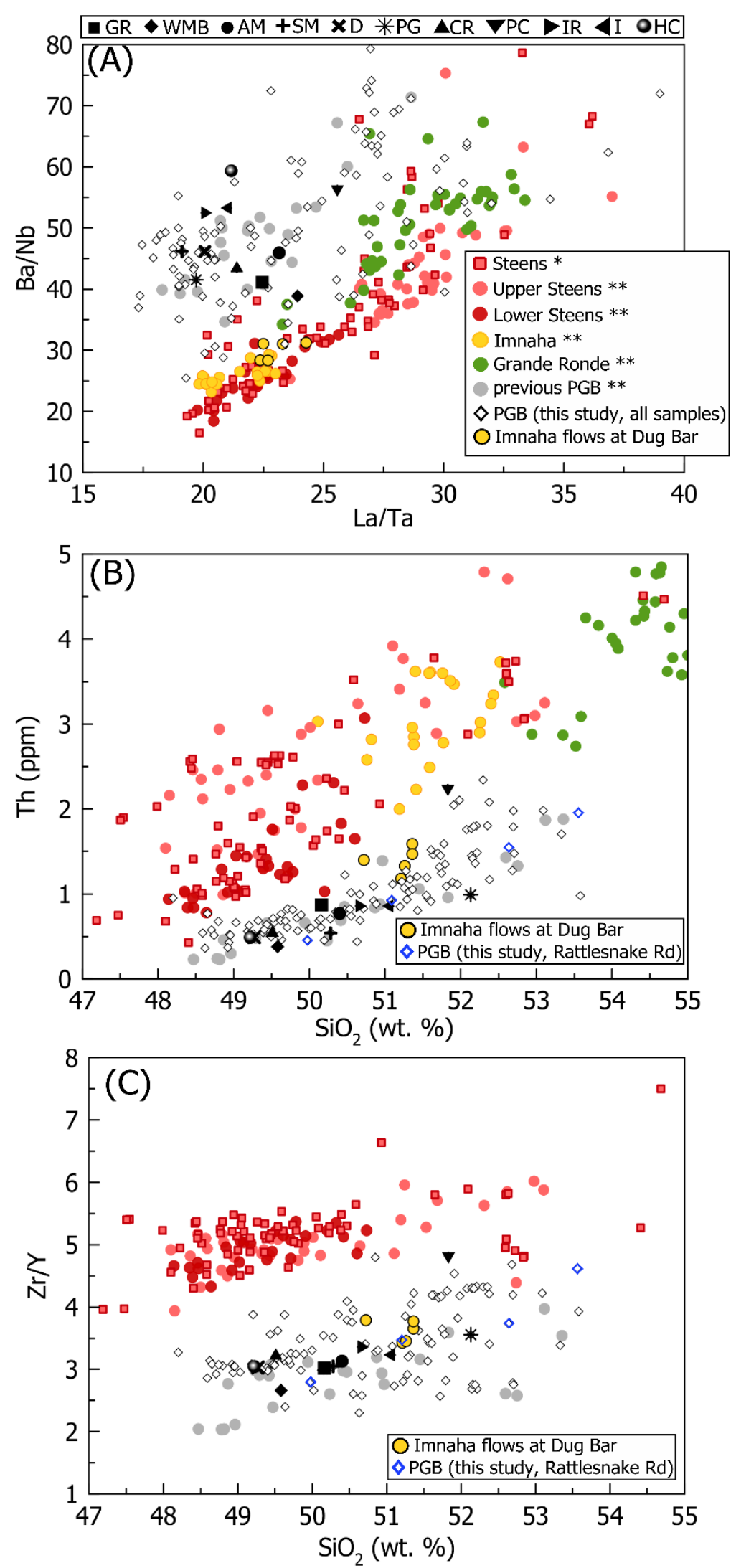

Figure 1.2 Geochemistry of our Picture Gorge Basalt (PGB, northwestern United States) study samples compared to Steens Basalt data from Moore et al., (2018) [*] and all main-phase Columbia River Basalt Group (CRBG) units from Wolff and Ramos (2008) [**]; for Imnaha Basalt, only American Bar subgroup samples are plotted as only these Imnaha lavas occur in the study area of northeastern Oregon (Vic Camp, personal comm., 2019). Dated samples locations abbreviated as in Fig. 1.1. 


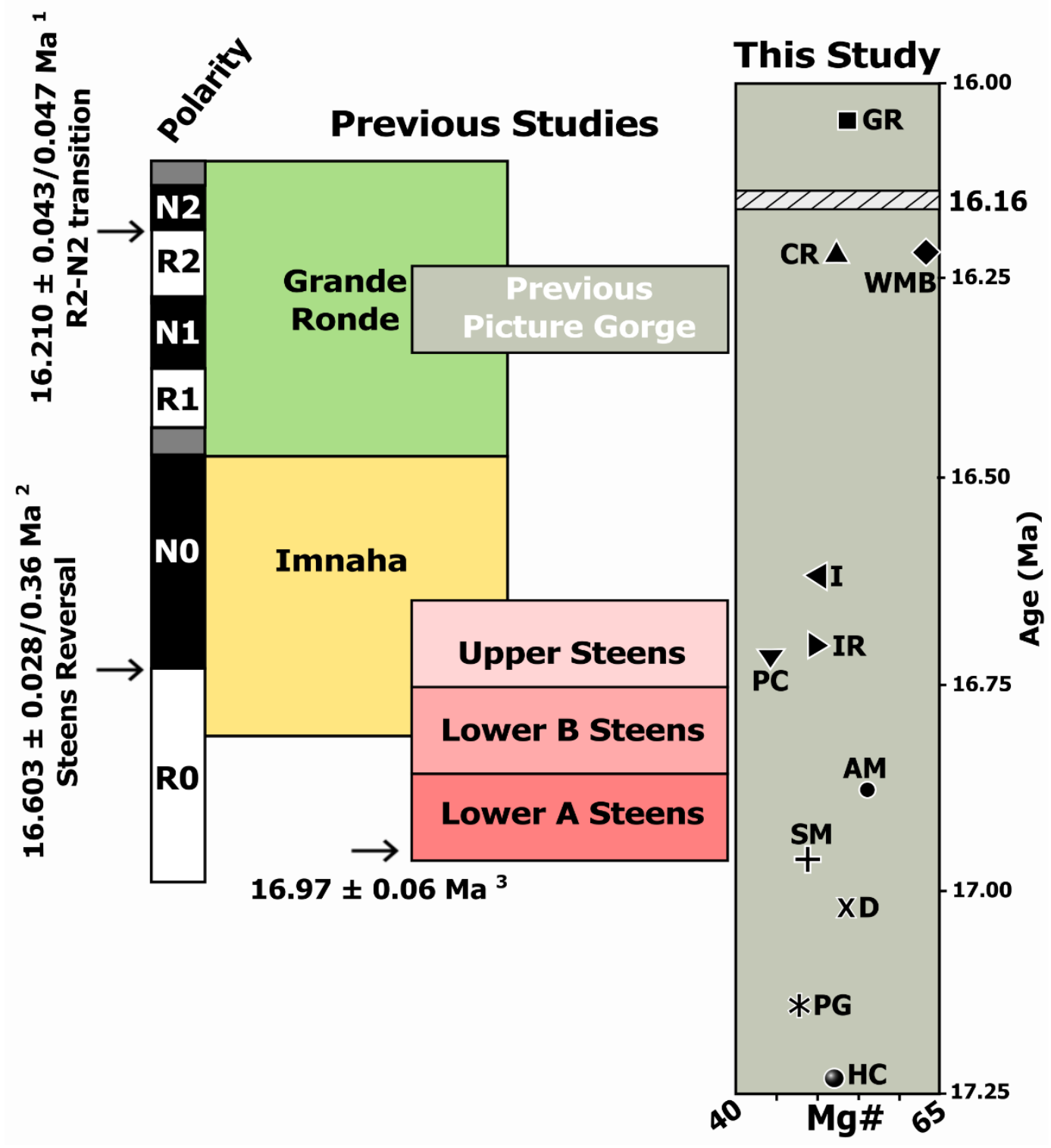

Figure 1.3 Stratigraphy of main-phase Columbia River Basalt Group (CRBG, northwestern United States) with our reported Picture Gorge Basalt (PGB) ages and associated Mg\#. The 16.16 Ma unit is unit 1 of the Dinner Creek Tuff (Streck et al., 2015). Additional ages: 1 Kasbohm and Schoene (2018), 2 Mahood and Benson (2017), 3 Moore, et al. (2018). All 40Ar/39Ar dates were calculated using Fish Canyon Tuff sanidine age of $28.201 \pm 0.023 \mathrm{Ma}$ after Kuiper et al. (2008), and U-Pb errors for Kasbohm and Schoene (2018) age are reported as $95 \%$ confidence intervals given for internal uncertainty and decay constant uncertainty. Dated sample locations are abbreviated as in Figure 1.1. 


\section{REFERENCES}

Bailey, M.M., 1989, Revisions to stratigraphic nomenclature of the Picture Gorge Basalt Subgroup, Columbia River Basalt Group, in Volcanism and tectonism in the Columbia River flood-basalt province: Geological Society of America Special Paper, 239 , p. $67-84$.

Baksi, A.K., 2013, Timing and duration of volcanism in the Columbia River Basalt Group: A review of existing radiometric data and new constraints on the age of the Steens through Wanapum Basalt extrusion, in Geological Society of America Special Paper, 497, p. 67-85.

Barry, T.L., Kelley, S.P., Reidel, S.P., Camp, V.E., Self, S., Jarboe, N.A., Duncan, R.A., Renne, P.R., Ross, M.E., Wolff, J.A. and Martin, B.S., 2013, Eruption chronology of the Columbia River Basalt Group, in The Columbia River Flood Basalt Province: Geological Society of America Special Paper, 497, p. 45-66.

Brown, C.E. and Thayer, T.P., 1966, Geologic map of the Canyon City quadrangle, northeastern Oregon: U.S. Geological Survey, scale 1:250 000, 1 sheet.

Camp, V.E., 1995, Mid-Miocene propagation of the Yellowstone mantle plume head beneath the Columbia River basalt source region: Geology, v. 23, p. 435-438.

Camp, V.E., Ross, M.E. and Hanson, W.E., 2003, Genesis of flood basalts and Basin and Range volcanic rocks from Steens Mountain to the Malheur River Gorge, Oregon: Geological Society of America Bulletin, v. 115, p. 105-128.

Camp, V.E. and Ross, M.E., 2004, Mantle dynamics and genesis of mafic magmatism in the intermontane Pacific Northwest: Journal of Geophysical Research: Solid Earth, v. 109, B08204, doi:10.1029/2003JB002838. 
Camp, V.E., Ross, M.E., Duncan, R.A., Jarboe, N.A., Coe, R.S., Hanan, B.B. and Johnson, J.A., 2013, The Steens basalt: Earliest lavas of the Columbia River basalt gro

up, in Geological Society of America Special Paper, 497, p. 87-116.

Carlson, R.W., 1984, Isotopic constraints on Columbia River flood basalt genesis and the nature of the subcontinental mantle. Geochimica et Cosmochimica Acta, v. 48, p. $2357-2372$.

Coffin, M.F., and Eldholm, O., 1994, Large igneous provinces: Crustal structure, dimensions, and external consequences: Reviews of Geophysics, v. 32, p. 1-36.

Ernst, R. E. \& Buchan, K. L., 1997. Giant radiating dyke swarms: Their use in identifying pre-Mesozoic large igneous provinces and mantle plumes. Geophys. Monograph 100, 297-333.

Ernst, R.E., Buchan, K.L. and Campbell, I.H., 2005. Frontiers in large igneous province research. Lithos, 79(3-4), p.271-297.

Ernst, R.E., Liikane, D.A., Jowitt, S.M., Buchan, K.L. and Blanchard, J.A., 2019. A new plumbing system framework for mantle plume-related continental Large Igneous Provinces and their mafic-ultramafic intrusions. Journal of Volcanology and Geothermal Research, 384, p.75-84.

Fruchter, J.S. and Baldwin, S.F., 1975. Correlations between dikes of the Monument swarm, central Oregon, and Picture Gorge Basalt flows: Geological Society of America Bulletin, v. 86, p. 514-516.

Geist, D. and Richards, M., 1993, Origin of the Columbia Plateau and Snake River plain: Deflection of the Yellowstone plume: Geology, v.21, p. 789-792. 
Glen, J.M. and Ponce, D.A., 2002, Large-scale fractures related to inception of the Yellowstone hotspot: Geology, v. 30, p. 647-650.

Hill, R.I., Campbell, I.H., Davies, G.F., and Griffiths, R.W., 1992, Mantle plumes and continental tectonics: Science, v. 256, p. 186-193.

Hoernle, K., Rohde, J., Hauff, F., Garbe-Schönberg, D., Homrighausen, S., Werner, R. and Morgan, J.P., 2015, How and when plume zonation appeared during the 132 Myr evolution of the Tristan Hotspot. Nature Communications, 6, p.7799.

Hooper, P.R., Binger, G.B. and Lees, K.R., 2002, Ages of the Steens and Columbia River flood basalts and their relationship to extension-related calc-alkalic volcanism in eastern Oregon: Geological Society of America Bulletin, v. 114, p. 43-50.

Jarboe, N.A., Coe, R.S., Renne, P.R. and Glen, J.M., 2010, The age of the Steens reversal and the Columbia River Basalt Group: Chemical Geology, v. 274, p. 158-168.

Kasbohm, J. and Schoene, B., 2018, Rapid eruption of the Columbia River flood basalt and correlation with the mid-Miocene climate optimum: Science Advances, v. 4, DOI: $10.1126 /$ sciadv.aat8223.

Mahood, G.A. and Benson, T.R., 2017, Using ${ }^{40} \mathrm{Ar} /{ }^{39} \mathrm{Ar}$ ages of intercalated silicic tuffs to date flood basalts: Precise ages for Steens Basalt Member of the Columbia River Basalt Group: Earth and Planetary Science Letters, v. 459, p. 340-351.

Moore, N.E., Grunder, A.L. and Bohrson, W.A., 2018, The three-stage petrochemical evolution of the Steens Basalt (southeast Oregon, USA) compared to large igneous provinces and layered mafic intrusions: Geosphere, v. 14, p. 2505-2532.

Morgan, W.J., 1981, Hotspot tracks and the opening of the Atlantic and Indian oceans, in Emiliani, C-, ed., The sea, Volume 7: New York, Wiley Interscience, p. 443-475. 
Nathan, S. and Fruchter, J.S., 1974, Geochemical and paleomagnetic stratigraphy of the Picture Gorge and Yakima basalts (Columbia River Group) in central Oregon: Geological Society of America Bulletin, v. 85, p. 63-76.

Reidel, S.P., Camp, V.E., Tolan, T.L. and Martin, B.S., 2013, The Columbia River flood basalt province: Stratigraphy, areal extent, volume, and physical volcanology, in Geological Society of America Special Paper, 497, p. 1-43.

Peate, D.W., Barker, A.K., Riishuus, M.S., Andreason, R., 2008. Temporal variations in crustal assimilation of magma suites in the East Greenland flood basalt province: tracking the evolution of magmatic plumbing systems. Lithos 102, 179-197.

Schoene, B., Samperton, K.M., Eddy, M.P., Keller, G., Adatte, T., Bowring, S.A., Khadri, S.F. and Gertsch, B., 2015, U-Pb geochronology of the Deccan Traps and relation to the end-Cretaceous mass extinction. Science, v. 347, p. 182-184.

Streck, M.J., Ferns, M.L. and McIntosh, W., 2015, Large, persistent rhyolitic magma reservoirs above Columbia River Basalt storage sites: The Dinner Creek Tuff eruptive center, eastern Oregon. Geosphere, 11(2), p.226-235.

Streck, M.J., McIntosh, W., and Ferns, M.F. 2017, Columbia River Rhyolites: Agedistribution patterns and their implications for arrival, location, and dispersion of flood basalt magmas in the crust: Geological Society of America Abstracts with Programs, Session. 239, No. 7.

Swanson, D.A., Wright, T.L., Hooper, P.R. and Bentley, R.D., 1979, Revisions in stratigraphic nomenclature of the Columbia River Basalt Group, in Contributions to Stratigraphy: U.S. Geological Survey Bulletin 1457-G, 59 p. 
Watkins, N.D. and Baksi, A.K., 1974. Magnetostratigraphy and oroclinal folding of the Columbia River, Steens, and Owyhee basalts in Oregon, Washington, and Idaho: American Journal of Science, v. 274, p. 148-189.

Webb, B.M., Streck, M.J., McIntosh, W., and Ferns, M.L. and 2018, The Littlefield Rhyolite and associated mafic lavas: Bimodal volcanism of the Columbia River magmatic province, with constraints on age and storage sites of Grande Ronde Basalt magmas: Geosphere, v. 15, no. 1.

Wolff, J.A., Ramos, F.C., Hart, G.L., Patterson, J.D. and Brandon, A.D., 2008, Columbia River flood basalts from a centralized crustal magmatic system: Nature Geoscience, v. 1, p. 177-180.

Wolff, J.A. and Ramos, F.C., 2013, Source materials for the main phase of the Columbia River Basalt Group: Geochemical evidence and implications for magma storage and transport, in The Columbia River Flood Basalt Province: Geological Society of America Special Paper, 497, p. 273-291. 


\title{
CHAPTER 2
}

\section{REASSESSMENT OF THE SPATIAL DISTRIBUTION AND ERUPTIVE VOLUME OF THE PICTURE GORGE BASALT}

\begin{abstract}
The Picture Gorge Basalt (PGB) of the Columbia River Basalt Group (CRBG) has been limited in its spatial distribution and volume $\left(<\sim 3,000 \mathrm{~km}^{3}\right)$ and thought to not extend far from its type locality at Picture Gorge. At present, PGB represents only 1.1 volumetric percent of the CRBG with a relatively limited distribution of approximately 10,000 km² (Tolan et al., 1987; Reidel et al., 2013; Barry et al., 2013). New age data illustrates that the PGB is the earliest and longest eruptive interval compared to other main-phase CRBG formations (Cahoon et al., 2020), and some dated basaltic flows are far $(\sim 100 \mathrm{~km})$ from the previously mapped extent. This study focuses on these extensive outcrops of basaltic lavas and dikes south of the type locality at Picture Gorge, in order to reassess the spatial distribution and eruptive volume of the PGB.
\end{abstract}

Field observations coupled with geochemical data indicate PBG lavas covered a significantly greater area than shown on the published geologic maps. Additional mafic dikes located further south of the original mapped distribution of PGB have geochemical compositions and northwest trending orientations comparable to the dikes of the Monument dike swarm. Some of these dikes had been previously mapped, but lacked age or compositional data. Newly identified lava flows are correlated to the existing PGB stratigraphy within the original mapped extent where stratigraphic control is welldefined. Correlation is facilitated by comparison of 20 major and trace elemental 
abundances via a principal component analysis. This provides a new detailed distribution of PGB with stratigraphic significance. Total distribution of PGB lavas and dikes more than doubles, and brings the eruptive volume to a new minimum of $>\sim 4,200 \mathrm{~km}^{3}$. Geochemically correlated basaltic lavas and dikes in the extended distribution of PGB represent the earlier and later sections of the internal PGB stratigraphy. This is an intriguing observation as new PGB geochronological data suggest a short hiatus of $\sim 400$ ka during eruptive activity which occurred from 17.23 Ma to 15.76 Ma.

The geochemical identifiers used to differentiate PGB from other main-phase formations of the CRBG include lower $\mathrm{TiO}_{2}(<2$ wt. \%) concentrations, lower incompatible trace elements (i.e. $\mathrm{La}, \mathrm{Th}$, and $\mathrm{Y}$ ) abundances, and a more pronounced enrichment in large-ion-lithophile elements (LILE) on a mantle-normalized trace element diagram. Geochemical characteristics of PGB are interpreted to represent a magmatic source component distinct from the other main-phase CRBG units, possibly a localized back-arc like mantle melt. However, this source cannot be spatially restricted as there are observed PGB lava flows and dikes extending as far east as Lake Owyhee and as far south as Hart Mountain, Oregon. In context with the existing stratigraphy and the new extent of PGB lavas and dikes, these ages and coupled geochemical signatures demonstrate that this metasomatized mantle component was not localized, but was tapped across a wide regional area. 


\section{INTRODUCTION}

Continental flood basalts are a type of large igneous province (LIP) composed of lava flows, pyroclastic rocks, dikes, and sills. The majority of erupted material is often observable as thick sections of laterally continuous basaltic lavas. Stratigraphic sections of flood basalts preserve records of chemical fluctuations associated with the dynamics of mantle upwellings and provide insights into differentiation processes in the crust and processes through time. Geochemical signatures, phenocryst content, magnetic polarity, and radiometric ages within these basaltic lavas can be evaluated to categorize components or subunits of flood basalt provinces.

The Columbia River Basalt Group (CRBG) is the youngest and least volumetric flood basalt province, and its excellent preservation has provided geologists with an opportunity to better understand the eruptive evolution of a continental flood basalt. Similar to other flood basalt provinces worldwide, volcanism of the CRBG was active for millions of years, but the majority of material erupted during the first million years, or "main-phase" of activity (Coffin and Eldholm, 1994). This main-phase period was between approximately 17 and 16 million years ago, and basaltic lavas of this interval can be subdivided into four units which include the Steens Basalt, Imnaha Basalt, Grande Ronde Basalt, and the Picture Gorge Basalt (PGB) (Reidel et al, 2013).

Models for CRBG magmatism range from those that do not necessitate the involvement of a mantle plume in producing the CRBG but are largely driven tectonically (Hales et al., 2005; Liu and Stegman, 2012) to those that rely on the Yellowstone plume as the primary driver of volcanism across the province (Brandon and 
Goles, 1988; Hooper and Hawkesworth, 1993; Geist and Richards, 1993; Camp and Ross, 2004; Hooper et al., 2007; and Camp and Hanan, 2008). In the latter class of models, the main-phase units of the CRBG are thought to represent mixtures of this deepseated plume material with other contributing components such as depleted mantle variably altered by subduction fluids, recycled basaltic crust within a plume, and accreted terranes and crustal material (Carlson et al., 1981; Carlson, 1984; Brandon et al., 1993; Hooper and Hawkesworth, 1993; Takahashi et al., 1998; Wolff et al., 2008).

Establishing stratigraphic packages and distributions are imperative to understand emplacement patterns and total eruptive volumes, and in conjunction with petrologic data provide the framework for models of magmatic formation. In the case of the CRBG, decades of work have improved our understanding of the timing, spatial extent, and geochemical evolution of these flood basalt lavas (Carlson, 1984; TWolff et al., 2008; Reidel et al., 2013; Kasbohm and Schoene, 2018). This study focuses on basaltic lavas and dikes of Picture Gorge Basalt and their regional distribution, their eruptive stratigraphy, and context to other main phase CRBG units. I demonstrate that lavas and dikes of the PGB are dispersed across a significantly greater area than previously recognized (Bailey, 1989), leading to new stratigraphic relationships with other main phase CRBG units and potentially new eruption locations of PGB-like magmas and to a wider distribution area in eastern Oregon. The increased distribution area, in turn, leads to an increase in eruptive volume for the Picture Gorge Basalt. 


\section{GEOLOGIC SETTING}

\section{Main-Phase Lavas of the Columbia River Basalt Group}

The Columbia River Basalt Group (CRBG) is preserved in the geologic record as thick stacks of basaltic lavas throughout Oregon and Washington (Fig. 2.1). Volcanism associated with the CRBG occurred between 17.2 to $5.5 \mathrm{Ma}$, but the majority of the extruded volume ( $\sim 93 \%$ ) erupted during the initial $\sim 1.2$ million years of activity (Camp et al., 2017; Cahoon et al., 2020). This eruptive interval is known as the main-phase of CRBG activity ( 17.2-16 Ma), and basaltic lavas erupted during this time include the Steens, Imnaha, Grande Ronde, and Picture Gorge Basalts (PGB), distinguished by relative age, vent locations, and chemical composition (cite.g. Reidel et al., 2013).

Initially inferred from field observations, lavas of the PGB and lavas of the Grande Ronde Basalt were thought to have erupted concurrently. Lava flows of PGB appear to interfinger at the N1 and R2 magnetostratigraphic intervals (Reidel et al., 2013), and early dating of multiple lava flows within the type section at Picture Gorge indicated an age range from 15.9 to $14.7 \mathrm{Ma}$ (Watkins and Baksi, 1974). Eruptive timing of the PGB has been recently refined with high-precision ${ }^{40} \mathrm{Ar} /{ }^{39} \mathrm{Ar}$ incremental heating ages, with ages as old as 17.23 Ma (Cahoon et al., 2020). Ages and locations of newly dated PGB samples indicate they are older and more widely distributed than previously alleged (Cahoon et al., 2020). Other recent dating studies have also reported older age data - including $16.210 \pm 0.043 / 0.047 \mathrm{Ma}$ for the R2-N2 transition, consistent with the interpretation of Jarboe et al. (2010) that the N0-R1 transition is also older, at $16.5 \mathrm{Ma}$. These older ages have been confirmed by U-Pb dating of zircons from interbedded silicic 
tuffs (Mahood and Benson, 2017; Kasbohm and Schoene, 2018).

\section{PGB Stratigraphy and Geochemistry}

Merriam (1901) correlated basaltic lava flows at Picture Gorge, Oregon with the previously established "Columbia Lavas" throughout the Columbia River Gorge. The first reference to the name Picture Gorge Basalt (PGB) was by Waters (1961) who distinguished PGB and the Yakima Basalt as the chief subunits of the CRBG. Following this correlation, the PGB has been mapped and described in detail between John Day and Kimberly, Oregon (Fig. 2.1) (Wilcox and Fisher, 1966; Brown and Thayer, 1966; Bentley and Cockerham, 1973; Nathan and Fruchter, 1974; Robinson, 1975; Fruchter and Baldwin, 1975, Bailey, 1989). Magmas in this region erupted through accreted terrane material of Paleozoic to Mesozoic age consisting of metamorphosed assemblages of volcanic and ophiolitic rocks, forearc basin sediments, and through Cenozoic volcanic and volcaniclastic rocks of the Eocene Clarno and Oligocene John Day Formations (Brown and Thayer, 1966; Robinson, 1975; Hooper and Swanson, 1990).

Stratigraphic work has divided the PGB into three subunits which include the Twickenham, Monument Mountain, and Dayville Basalts (Fig. 2.2). These three subunits are further subdivided into 17 members and some dikes are grouped as high-Mg dikes due to their distinct composition (Bailey, 1989a).Subunits were originally differentiated by plagioclase abundance, $\mathrm{TiO}_{2}$ and $\mathrm{MgO}$ content (wt. \%), and magnetic orientation (Osawa and Goles 1970; Nathan and Fruchter, 1974; McDougall 1976; Swanson et al. 1979; Watkins and Baksi, 1974; Goles 1986; Bailey 1989a) (Figs. 2.2, 2.3). These PGB lavas have a maximum thickness of $800 \mathrm{~m}$ and were interpreted to form a shield-like 
morphology across their exposure area (Swanson et al. 1979; Brandon et al., 1993; Bailey, 1989a).

The Twickenham Basalt is the earliest of the three PGB subunits and was originally divided into three members (Bailey, 1989a). Lavas of the Twickenham Basalt are plagioclase-phyric, normally magnetized, and contain $\mathrm{TiO}_{2}>1.5$ wt. $\%$ and $\mathrm{MgO}>6$ wt. \% (Bailey, 1989a) (Fig. 2.2, 2.3). These basalts are interpreted to have erupted across areas of moderate relief forming intracanyon flows exemplified by Kentucky Butte near Twickenham, Oregon (Swanson et al., 1979). Lavas of the Twickenham Basalt are capped by predominantly aphyric basalts of the Monument Mountain subunit, further subdivided into four members (Fig. 2.2). This subunit is normally magnetized, forms colonnades and entablatures, and contains $\mathrm{TiO}_{2}$ between 1.4-1.7 wt. $\%$ and $\mathrm{MgO}$ between 5-8.0 wt. \% (Bailey, 1989a). The Monument Mountain Basalt is overlain by variably plagioclase-phyric basaltic flows of the Dayville Basalt subunit. Exposures of Dayville Basalt are small in area and restricted to the highest elevations and peaks, which has led to the interpretation that there has likely been significant post-emplacement erosion (Bailey, 1989a). Currently the only documented magnetic reversal in PGB lavas occurs within the Dayville Basalt, and one member exhibits transitional magnetic polarity, the Branson Creek member (Watkins and Baksi, 1974)(Fig. 2.2). The Dayville Basalt subunit includes the most evolved lavas with $<6 \mathrm{wt} . \% \mathrm{MgO}$, elevated concentrations of incompatible elements (e.g. La $>10 \mathrm{ppm}$ ) and exhibits the most geochemical variability. In fact, the geochemical variability observed in all Dayville Basalt flows encompasses the entire compositional range of all three PGB subunits (Fig. 2.3). As a result of this 
compositional diversity, Bailey (1989a) divided the Dayville Basalts into 10 members (Fig. 2.3), with some members comprised of only two flows (i.e. Horse Canyon, Little Tamarack, Stony Creek). Crustal assimilation in combination with fractional crystallization have been proposed to be the two main processes to account for the generation of the most evolved flows in the Dayville Basalts (Bailey, 1989b; Brandon et al., 1993). Due to the geochemical heterogeneity amongst Dayville Basalt members, each member of the Dayville Basalt is considered separately.

At the type locality of Picture Gorge, both the middle (Monument Mountain) and upper (Dayville Basalt) subunits of the PGB are exposed. Here, both $\mathrm{Mg}$ and $\mathrm{Cr}$ sharply decrease stratigraphically upward, while $\mathrm{K}, \mathrm{La}, \mathrm{Th}, \mathrm{Fe}, \mathrm{Rb}$, and the rare-earth elements increase (Bentley and Cockerham, 1973; Nathan and Fruchter, 1974; Swanson et al., 1979). However, basalt flows exhibiting similar textural features (i.e. predominantly aphyric or containing large plagioclase phenocrysts) define different geochemical groups, independent of their subunit classification (Bailey, 1989a).

\section{Basalt of Malheur Gorge}

More than $100 \mathrm{~km}$ southeast of Picture Gorge, a several hundred-meter-thick sequence of basaltic lavas are exposed along Malheur Gorge - often referred to as the basalt of Malheur Gorge (Figs. 2.1, 2.4) (cf., Kittleman et al., 1965, 1967; Evans, 1990; Webb et al., 2018). This area is critical for stratigraphic inferences for main phase CRGB members. The basalt of Malheur Gorge has later been subdivided by stratigraphic position and textural characteristics into the Pole Creek formation at the base, the Birch Creek formation, and the overlying Hunter Creek Basalt (Lees, 1994). These basaltic 
lavas have been correlated to main-phase units of Steens, Imnaha, and Grande Ronde Basalt of the CRBG and hence Malheur Gorge is the only known location where three main-phase CRBG units are exposed together (Hooper et al., 2002; Camp et al., 2003).

The interpretation that many of the lower basaltic lavas at Malheur Gorge are geochemically correlative to Steens Basalt arises from the spatial proximity to Steens Mountain and the identification of sparse basaltic outcrops in between (Camp et al., 2003) (Fig. 2.1). However, new data have revealed that multiple basalt lavas in Malheur Gorge have geochemical characteristics more akin to the PGB than Steens Basalt (Cahoon et al., 2020). This observation raises questions on the geochemical nature of the basalts belonging to the Pole Creek formation, and the CRBG subunits present within Malheur Gorge.

\section{METHODS}

New geochemical data on previously mapped but unnamed basaltic lavas, some located over $100 \mathrm{~km}$ from the nearest PGB location, indicate the PBG extends beyond its current distribution. Samples from known PGB localities as well as new locations that are stratigraphically and geochemically correlated with PGB (Fig. 2.5), were selected for ${ }^{40} \mathrm{Ar} /{ }^{39} \mathrm{Ar}$ dating. Nine of the fourteen PGB ages pass Baksi's (2013) statistical test for reliability. All dated samples are groundmass separates, to reflect an eruptive age. Geochronological data and age spectra for all samples are located in the appendices (Appendix B and C). 


\section{Field Sampling}

Fieldwork and sample collected was focused across the Malheur and Ochoco National Forest in a broad corridor between John Day and Burns, Oregon. In this region age is stratigraphically constrained by younger rhyolitic units. Field sampling also included locations in the Picture Gorge type locality and in regions where the other three main-phase units of the CRBG are present.

\section{Major and Trace Element Compositions}

Major and trace element data was acquired at the Peter Hooper GeoAnalytical Lab at Washington State University (WSU) using a Thermo-ARL Advant XP automated X-ray fluorescence spectrometer (XRF), and an Agilent 7700 inductively coupled plasma mass spectrometer (ICP-MS). For sample preparation, basaltic samples were crushed into chips using the Braun Chipmunk at WSU. Then, weathered surfaces were removed from the chips so that alteration wouldn't affect the results, and then chips were further crushed into a powder in a tungsten carbide shatterbox. The powder was then combined with dilithium tetraborate $\left(\mathrm{Li}_{2} \mathrm{~B}_{4} \mathrm{O}_{7}\right)$ in a ratio of $2: 1$, dilithium tetraborate to sample. The sample was fused into a bead in an oven at a temperature of $1000^{\circ} \mathrm{C}$. The beads were reground into powder, and one gram of powder was separated in order to make the ICP-MS bead. Two beads per sample were then made, again at $1000^{\circ} \mathrm{C}$, one for $\mathrm{XRF}$ and one for ICP-MS analysis. The XRF bead was analyzed in the XRF instrument, and the ICP-MS bead was dissolved for final analysis. These data provided whole-rock major and trace elemental data to confirm samples were PGB. This determination was further established using a statistical method Principal Component Analysis (PCA) where each sample was 
compared to previously identified CRBG main-phase lavas from the dataset of Wolff et al., 2008.

\section{Statistical Comparison via Principal Component Analysis}

Previous work of Bailey (1989) differentiated PGB lavas in the John Day Basin into three subunits composed of 17 different members. In addition to the 17 members, Bailey (1989a) also distinguished high-MgO dikes within the Monument dike swarm which were originally identified by Fruchter and Baldwin (1975). For the purposes of this study the high-MgO dikes are considered a member, yielding 18 total PGB members.

To determine how PGB samples collected as part of this study compared with the established stratigraphy, I utilized a principal component analysis (PCA) on major element and trace element geochemical data in RStudio (Appendix I). Three separate PGB datasets were utilized during this analysis: Bailey (1989), Wolff et al (2008), and this study. The study by Wolff et al (2008) included a reanalysis of 23 PGB samples originally analyzed by Bailey (1989), and includes a sample from each of the 17 PGB members in addition to a some high-Mg basaltic dikes. When comparing geochemical data for the same samples [XRF and ICP-MS data of Wolff et al. (2008) to the original XRF data of Bailey $(1989 \mathrm{a}, \mathrm{b})]$, concentrations of most elements are similar, with the exception of $\mathrm{Rb}$ and $\mathrm{Nb}$ (Appendix $\mathrm{D}$ ). Due to the poor correlation of the elements $\mathrm{Rb}$ and $\mathrm{Nb}$ between XRF data (Bailey, 1989a) and ICP-MS data (Wolff et al., 2008) from the same samples, the elements $\mathrm{Rb}$ and $\mathrm{Nb}$ were excluded and not incorporated in any statistical analyses. To evaluate the accuracy and robustness of this statistical tool, geochemical data for 23 reanalyzed PGB samples (Wolff et al., 2008) were initially 
compared to 155 samples from the original PGB geochemical dataset (Bailey, 1989). To do this, each sample in the original dataset was labeled as the PGB subunit or member it was classified as by Bailey (1989a). Within the original dataset each sample was labeled as the Twickenham or Monument Mountain subunit, or more specifically as a member within the youngest PGB subunit, the Dayville Basalt. This distinction was most useful due to a limited number of samples within some PGB members of the Twickenham and Monument Mountain subunits (ex. Stony Creek member, $\mathrm{n}=2$ ), and the geochemical variability of all the members within the Dayville Basalt. The geochemical variability within all members of the Dayville Basalt was not useful when considered as one geochemical subunit. This approach predicted at $87 \%$ accuracy the correct PGB subunit or member for each reanalyzed sample in the dataset of Wolff et al. (2008), or 20 of the 23 total samples were predicted correctly (Table 2.1). With a statistical tool that has now been assessed for accuracy, geochemical data for my PGB samples was then compared to the original dataset of Bailey (1989). The approach outlined above is condensed into the following procedural steps:

1. Sample 1:1 elemental comparison: XRF data (Bailey, 1989) to ICP-MS data (Wolff et al., 2008)

2. Exclude elements which are poorly correlated for geochemical analysis of the same sample $\left(\mathrm{R}^{2}\right.$ value $\left.<0.9\right)$

3. Using geochemical data from 23 reanalyzed PGB samples with known subunit and member classification, compare samples from Wolff et al (2008) to Bailey 
(1989a) with a PCA and gauge accuracy of correctly predicted PGB subunits and members.

4. Once the code has been refined to yield the highest accuracy, compare geochemical data of my PGB samples to the original dataset of Bailey (1989) using the same PCA to predict PGB subunit (Twickenham and Monument Mountain) or specific member (Dayville Basalt).

Each PGB sample included in this study has been classified as a PGB subunit using this PCA prediction, the results are included in Appendix A.

\section{Area and Volume Calculations}

Samples in my PGB dataset were classified as a subunit and their locations were mapped using ArcGIS. To determine the added area from my PGB samples, I drew polygons around samples located in the extended distribution which were classified as the same subunit. To determine the added volume from my PGB samples, I used the average thickness of members in the respective subunit and multiplied it by the newly determined area. This provided a low estimate for newly added PGB volume. An upper limit was calculated by multiplying the newly determined area by $0.22 \mathrm{~km}$, the average PGB thickness calculated by Tolan et al. (1987). This is a best estimation, many newly identified PGB lavas are laterally discontinuous exposures and are likely not the same thickness as the original mapped extent of the PGB. 


\section{RESULTS}

\section{PGB Original Extent}

The PGB subunit of the CRBG has been limited in its spatial distribution and thought to not extend far from its type locality at Picture Gorge based on field studies completed throughout the 1970-1980's (Fig. 2.1, Table 2.2). North-northwest trending feeder dikes are compositionally and spatially associated with the PGB and have collectively been called the Monument dike swarm after Monument Mountain (Baldwin, 1973; Frutcher and Baldwin, 1975). PGB lavas and dikes have been mapped as far north as Lonerock and as far south as the Aldrich Mountains (Fig. 2.1) (Brown and Thayer, 1966; Bentley and Cockerham, 1973; Nathan and Frutchter, 1974; Robinson, 1975; Fruchter and Baldwin, 1975). The detailed stratigraphic work of Bailey (1989a,b) was based on field data including paleomagnetic and lithological data, and geochemical evidence, and confined spatially to north of the John Day Valley.

\section{Correlating Samples with PGB Stratigraphy}

In the stratigraphic framework by Bailey (1989a), the uppermost and interpreted youngest PGB subunit, the Dayville Basalt, is limited in geographic extent and highly variable in geochemistry. Conversely, the older subunits the Twickenham Basalt and overlying Monument Mountain Basalt appear more homogeneous consisting of lavas with intermediate ( $\sim 6$ wt. $\% \mathrm{MgO})$ to high (7.5 wt. \%) $\mathrm{MgO}$ content (Fig. 2.3). At Picture Gorge, there are 15 distinct lava flows exposed, dipping to the south at $18^{\circ}$ (Brown and Thayer, 1966). I sampled the lowermost and uppermost lavas at Picture Gorge and found that they are geochemically correlative with the Camas Creek and 
Hamilton member, respectively, consistent with the interpretation of Bailey (1989a)

(Figs. 2.2, 2.6). This interpretation was made using Principal Component Analysis on major and trace element geochemical data, and substantiated with a review of $\mathrm{Zr}, \mathrm{TiO}_{2}$, and $\mathrm{Cr} / \mathrm{Ni}$ values (Fig. 2.3).

The Twickenham Basalt is the earliest PGB subunit and exposed along the western portion of the previously mapped extent. I sampled a section of multiple lava flows at Kentucky Butte, the type locality of the Twickenham Basalt, and confirmed the geochemically similarity to this subunit (Bailey, 1989a) (Fig. 2.6). Similarly, the uppermost flows at Monument Mountain and Tamarack Mountain conform with the stratigraphy established at each location by Bailey (1989a) (Fig. 2.6). At Monument Mountain, I observe the Monument Lookout member at the top, and at Tamarack Mountain I observe the Hamilton member capping the section - both members are part of the Monument Mountain subunit (Figs. 2.6, 2.7). These interpretations were made on the basis of $\mathrm{TiO}_{2}, \mathrm{Cr} / \mathrm{Ni}$, and trace element concentrations such as $\mathrm{La}$ and $\mathrm{Zr}$ (ppm), and further corroborated through the PCA on PGB geochemical data.

Examining the compositional variability within each PGB subunit (Twickenham, Monument Mountain, and Dayville), major and trace element concentrations can overlap $(1 \sigma)$ among the three subunits. Unfortunately, many of the previously geochemical criteria that were used to categorize flows into distinct members, are not useful. Because there is a significant amount of compositional overlap among PGB members and compositional variation within each member, member correlation based on any single element or single ratio is tenuous. 
In summary, I am able to correlate select lavas sampled from specific stratigraphic intervals to the described PGB stratigraphy (Bailey, 1989a). There are however multiple PGB lavas that exhibit overlapping member compositions. Even with clear but limited flow stratigraphy exposed, these compositions ultimately lead to uncertainty in their subunit correlation.

\section{Stratigraphy in Context of New Ar/Ar Ages}

Combining the stratigraphy with recently reported ${ }^{40} \mathrm{Ar} /{ }^{39} \mathrm{Ar}$ ages (Cahoon et al., 2020) allows us to shed light on emplacement time of basal PGB units at different locations and can correlate absolute ages within the flow stratigraphy based on the wholerock composition of undated PGB flows (Fig. 2.7, 2.8).

At Picture Gorge the lowermost basalt yields a $17.14 \pm 0.04$ Ma weighted mean age, within error of the inverse isochron age (PG; sample CAH17-245, Table 1.1) (Cahoon et al., 2020). This age and compositional correlation with the Camas member of the Monument Mountain Basalt subunit of the PGB, implies that the lower PGB subunit (Twickenham Basalt), would need to be even older. Another basal PGB lava located at Holmes Creek (HC; sample CAH17-222A) $20 \mathrm{~km}$ north of the type locality has a miniplateau age of $17.23 \pm 0.04 \mathrm{Ma}$ (Cahoon et al., 2020). This lava is geochemically similar to the Stony Creek member of the Monument Mountain subunit of the PGB stratigraphy. The Stony member is stratigraphically below the Camas member and reported ages are consistent with this finding (Cahoon et al., 2020) (Fig. 2.8). A third basal PGB lava near the town of Dale (D; sample CAH17-200) is located $80 \mathrm{~km}$ northeast of Picture Gorge. This lava is exposed directly above the 33 Ma tuff of Dale of the Tower Mountain 
volcanic field (Brown, 2017) and yields a plateau age of $17.02 \pm 0.03 \mathrm{Ma}$, within error of the inverse isochron age. Geochemically, this basalt lava is most similar to the Bologna member of the Twickenham Basalt, the supposedly lowest PGB subunit. This new age is inconsistent with the existing stratigraphy which could have several reasons. More importantly, however, all newly dated basal PGB lavas represent PGB members of the lower third of the internal PGB stratigraphy thus placing onset of PGB eruptions to $>17$ Ma (Fig. 2.8).

At the southernmost extent of the PGB and Monument dike swarm (Fruchter and Baldwin, 1975), an aphyric dike in the Aldrich Mountains (AM; sample CAH15-023) yields an age plateau of $16.88 \pm 0.06 \mathrm{Ma}$ (Cahoon et al., 2020). This recently reported age is robust as it is within error of the inverse isochron age and has a concordant isochron with ${ }^{40} \mathrm{Ar} /{ }^{36} \mathrm{Ar}$ initial ratio of $296.22 \pm 0.28$. This age coupled with first-order observations of its geochemical characteristics indicate this dike is likely a member of the Twickenham Basalt, the oldest of the three PGB subunits (Fig. 2.3). However, the principal component analysis suggests this dike is best geochemically correlated to a different member, the Dale member of the Dayville Basalt, the youngest of the three PGB subunits. While the accuracy of the PCA on the geochemical similarities of PGB subunits was gauged against known samples (and correct at $>85 \%$ ), this specific prediction is questionable. All previous samples of the Dale member cluster tightly in geochemical space, and my sample (CAH15-023) does not reflect this consistency (Fig. 2.3). Furthermore, basalts of the Dale member exhibit elevated $\mathrm{Cr} / \mathrm{Ni}$ ratios $(>3.1)$ and depleted incompatible element concentrations, while this sample has a $\mathrm{Cr} / \mathrm{Ni}$ ratio $<2$ 
(Fig. 2.3B). If indeed correlative with the Dale member, the $16.88 \mathrm{Ma}$ age of this dike would indicate the majority of the PGB erupted over a period of $\sim 300 \mathrm{ka}$, or suggests this member was not properly placed within the PGB stratigraphy. Overall, the oldest PGB samples with ages near $17 \mathrm{Ma}$, contain geochemical characteristics that are most similar to the inferred lower stratigraphic members of Bailey (1989a,b) (Fig. 2.8B).

\section{Extended Distribution}

Adjacent to original distribution area of the PGB, widespread un-studied, midMiocene basaltic lavas and dikes are exposed between the southern extent of the PGB and the presumed northern extent of Steens Basalt in a wide corridor of Malheur National Forest, eastern Oregon (Fig. 2.5). These basalts are depicted on earlier geologic maps (Wallace and Calkins, 1956; Brown and Thayer, 1966; Greene, Walker, and Corcoran, 1972) and distributed southeast of the Picture Gorge type locality. These lavas can be placed in the same stratigraphic interval as PGB flows of the original distribution by occurring below the 16.16 Ma Dinner Creek Tuff unit 1 (Streck et al., 2015) in the area between the towns of John Day and Burns along the western corridor to highway 395. Similar stratigraphic constraints have been revealed for other unassigned basalt lavas considerable distances west and southeast of the original distribution at Dooley Mountain (Large, 2016), at Castle Rock (Cruz, 2017), and north of Ford Harney along Rattlesnake Creek (Isom and Streck, 2016; Houston et al, 2017) (Fig. 2.1).

In addition, lavas previously assigned at Pole Creek in Malheur Gorge to other CRBG units reveal that they are compositionally more akin to PGB and hence should rather be reassigned (Cahoon et al., 2020). Careful evaluation of basaltic lavas exposed 
throughout this region thus provide an opportunity to expand the PGB distribution area and explore the petrogenetic and temporal transition between PGB and other CRBG units. Below, I first review compositional variations of PGB lavas in context of other main phase CRBG units, then identify compositional parameters that best distinguishes PGB from other CRBG units, and finally present results of geochemical correlation to local flows with PGB.

\section{PGB: Compositional Variability and Contrast to other Main Phase CRBG Units}

Main-phase CRBG units cover an extensive compositional spectrum often overlapping in terms of major, trace elemental, and isotopic compositions (Fig. 2.9). In general, samples of PGB have most compositional commonalities with Steens Basalt (e.g., Carlson, 1984; Wolff and Ramos, 2013) yet there are distinguishing features, the

most notable are that PGB has the lowest ${ }^{87} \mathrm{Sr} /{ }^{86} \mathrm{Sr}$, highest ${ }^{143} \mathrm{Nd} /{ }^{144} \mathrm{Nd}$ ratios, the lowest concentrations of some incompatible elements, and elevated ratios of large ion lithophile elements (LILEs) to high field strength elements (HFSEs).

The PGB can be distinguished from other main-phase units using a variety of geochemical parameters. In comparison to the Grande Ronde Basalt, the PGB exhibits lower concentrations of $\mathrm{SiO}_{2}($ mostly $<53 \mathrm{wt} . \%)$ and in general lower incompatible trace elements contents, for example, La, Y, and Hf (Fig. 2.9).

When compared to Steens and Imnaha Basalt, the PGB exhibits a comparable $\mathrm{SiO}_{2}$ range, approximately 48.5 to 53 wt.\% (Fig. 2.9). Imnaha Basalt contains $<51 \% \mathrm{SiO}_{2}$ for Rock Creek and $>51 \%$ for American Bar chemical types (cf. Hooper, 1974), and the Rock Creek subtype is not found along the Oregon plateau (V. Camp, personal comm.). 
At a given silica content, the PGB contains lower concentrations of various incompatible elements such as Th, Hf, La, and typically most HFSEs, and LREEs (Fig. 2.9). When evaluated against the Steens Basalt, the PGB contains lower Hf, Th, and La and is clearly separated from samples of Steens Basalt on a Sc versus $\mathrm{TiO}_{2}$ plot (Fig. 2.9). Other geochemical parameters provide also a clear distinction such as $\mathrm{Zr} / \mathrm{Y}$ values. Samples of PGB have $\mathrm{Zr} / \mathrm{Y}<4$ at low $\mathrm{SiO}_{2}$ and $<4.5$ at high $\mathrm{SiO}_{2}$ while samples of Steens Basalt indicate ratios $>4$ and $>4.5$, respectively (Fig. 2.10C). Furthermore, the vast majority of PGB samples contain concentrations of Nb under $8.5 \mathrm{ppm}$ (Fig. 2.10D), which is useful to distinguish PGB from Imnaha lavas except for the stratigraphically lowest flows at Dug Bar (see discussion below).

\section{Locations with Lavas of PGB Composition}

Corridor from John Day to Burns Exposed south of the town of John Day, the main Monument dike swarm, and the Strawberry and Aldrich Mountains (Fig. 2.5), lava flows of mid-Miocene basalt are abundant but lack the lateral continuity of exposures further north near the type locality (Brown and Thayer, 1966; Greene et al., 1972). This is likely the result of the paleo-topography, subsequent erosion, or coverage by the 16.16 Ma Dinner Creek Tuff (unit 1) or younger widespread ignimbrites (e.g. Streck et al., 2015). Despite that the area is overlapping with the southern portion of the Monument dike swarm, these basalts have not been adopted into the distribution extent of the PGB.

Just south of the original distribution area, there are NNW trending plagioclasephyric dikes with PGB composition. At Inshallah Ranch (Fig. 2.5), one of these dikes (IR; sample CAH16-138) yields a plateau age of $16.70 \pm 0.09$ Ma. This age matches the 
inverse isochron age and has an ${ }^{40} \mathrm{Ar} /{ }^{36} \mathrm{Ar}$ initial ratio of $295.37 \pm 1.06$. Less than $20 \mathrm{~km}$ further south near the town of Izee, a PGB plagioclase-phyric lava (I; sample CAH16148) yields a plateau-age of $16.62 \pm 0.07 \mathrm{Ma}$, within error of the inverse isochron age. These two samples are similar in their texture, age, and geochemistry.

To the east, an olivine-phyric lava at West Myrtle Butte (WMB; sample CAH15007) yields an age plateau of $16.22 \pm 0.06 \mathrm{Ma}$ (Table 1.1). This age is within error of the inverse isochron age and has a ${ }^{40} \mathrm{Ar} /{ }^{36} \mathrm{Ar}$ initial ratio of $298.52 \pm 0.91$. Proximal to this flow, a plagioclase-phyric dike at Gilbert Ridge (GR; sample MS-11-6) yields a plateau age of $16.06 \pm 0.14 \mathrm{Ma}$, which places it during the younger eruptive period of the PGB (Fig. 2.8B). This dike was not previously included as part of the Monument dike swarm and does not protrude from the surrounding country rock. This lack of topographic relief is different from the bulk of the PGB dikes to the north in the Monument dike swarm extent. Finally, near the southern end of this corridor, a PGB lava is exposed at the top of Snow Mountain, a topographic high on the north side of the High Lava Plains with an elevation of over 2,200 $\mathrm{m}$. This sample (SM; sample CAH16-174A) reflects an age at the older end of the PGB age spectrum yielding a plateau age of $16.96 \pm 0.07 \mathrm{Ma}$ (Table 1.1). This date is robust as it is within error of the inverse isochron age and has a ${ }^{40} \mathrm{Ar} /{ }^{36} \mathrm{Ar}$ initial ratio of $296.88 \pm 0.34$ (Appendix B and C) (Cahoon et al., 2020).

Rattlesnake Road East of the town of Burns, there are multiple lavas of PGB composition exposed along Rattlesnake Road (Fig. 2.1). Temporally, these basaltic lavas are stratigraphically constrained as they are over- and underlie Unit 2 of the Dinner Creek Tuff, dated at approximately 15.6-15.5 Ma (Streck et al., 2015, Hanna, 2018). This field 
relationship indicates some basaltic lavas here are younger than the dated PGB lavas or dikes to the northwest surrounding the type locality.

Malheur Gorge and Castle Rock area Malheur Gorge is the only locality where lavas of Steens Basalt, coming from the south, interfinger with lavas from Imnaha and the Grande Ronde Basalt, both typically exposed further to the north. The presumed prior stratigraphy in Malheur Gorge is lower Steens Basalt overlain by upper Steens Basalt and/or Imnaha Basalt and in turn overlain by Grande Ronde Basalt (Fig. 2.4). Stratigraphic control in Malheur Gorge is aided by conspicuous outcrops of unit 1 of the Dinner Creek Tuff (16.16 Ma), which, by definition, is overlain by lavas of the Hunter Creek Basalt and underlain the Birch Creek lavas - both units belong to the Grande Ronde Basalt. In addition, intercalated rhyolite units of the Littlefield Rhyolite yield additional temporal constraints on the final flood basalt activity in Malheur Gorge (cf. Webb et al., 2018). Samples for this study were taken from lava flows stratigraphically below unit 1 of the Dinner Creek Tuff, exposed along three vertical sections within Malheur Gorge (Pole Creek, Horseshoe Bend, and Gold Creek) (Fig. 2.10).

Within the Pole Creek section, the lower basaltic lavas are identifiable as the lower Steens Basalt (Jarboe et al., 2008), but other identified basaltic flows exhibit geochemical signatures most similar to the PGB. At the Pole Creek section, PGB flows are overlain by the Birch Creek lavas, Dinner Creek Tuff unit 1, and capped by Hunter Creek Basalt (Fig. 2.10).

At Horseshoe Bend, approximately $10 \mathrm{~km}$ southwest of Pole Creek, the stratigraphy is comparable to one at Pole Creek. This stratigraphic section of basalt is 
also capped by the 16.16 Ma Dinner Creek Tuff. Below the Dinner Creek Tuff, there are first lavas belonging to the Birch Creek unit and these overlie lavas that have geochemical traits most similar to the PGB, Fig 2.10). Less than $10 \mathrm{~km}$ to the southeast at Gold Creek, additional basaltic lavas with PGB geochemical affinities are present, but their stratigraphic placement is unclear (Fig. 2.7).

Adding PGB to the lava packages occurring in Pole Creek, Horseshoe Bend, and Gold Creek indicates that Malheur Gorge is the area where all main phase CRBG units are in stratigraphic contact (Fig. 2.10). The lava flow immediately below Grande Ronde Basalt in Pole Creek yields an age plateau of $16.72 \pm 0.03 \mathrm{Ma}$ (PC; sample CAH16-065). This is within error of the inverse isochron age and has a concordant isochron with ${ }^{40} \mathrm{Ar} /{ }^{36} \mathrm{Ar}$ initial ratio of $302.88 \pm 1.14$. This date fits within the age relationships defined by Camp et al. (2003) but is not within $2 \sigma$ uncertainty with an apparently younger plagioclase age (16.45 $\pm 0.11 \mathrm{Ma}, 1 \sigma)$ of Steens Basalt in Pole Creek (Jarboe et al, 2010). This dated Steens Basalt lava is thought to represent the base of the Pole Creek section, although the section with Steens Basalt is not in direct stratigraphic continuity but is offset by a normal fault from the section with my dated sample and with PGB at the lowest stratigraphic exposures. Finally, the interpretation that all lower Pole Creek lavas are correlative to Steens Basalt is based on major element data (XRF only) from Binger (1997) and inferred field relationships, I revisit these inferences in the discussion (Fig. 2.12).

Along the northwestern edge of the Malheur Gorge, a prominent topographic high, Castle Rock, is interpreted as a source area for unit 1 of the Dinner Creek Tuff. 
Here, lavas with PGB compositions underlie Grande Ronde type basalts which, in turn, are capped by the 16.16 Ma Dinner Creek Tuff unit 1 (Cruz, 2017). These stratigraphic relationships at Castle Rock are similar to the sections at Pole Creek and Horseshoe Bend. The age of my PGB sample at Castle Rock (CR; sample MC-76-16) is consistent with observed stratigraphy and yields a slightly older age plateau of $16.23 \pm 0.09 \mathrm{Ma}$ (Cahoon et al., 2020). This plateau age is within error of the inverse isochron age and has a concordant isochron with ${ }^{40} \mathrm{Ar} /{ }^{36} \mathrm{Ar}$ initial ratio of $294.85 \pm 0.27$.

PGB extent in northeast Oregon Further northeast, lavas with PGB composition are exposed at Dooley Mountain, $150 \mathrm{~km}$ away from the type locality at Picture Gorge (Figs., 2.1, 2.11) (Large, 2016). Dooley Mountain is the northernmost rhyolite complex of the mid-Miocene rhyolite associated with initiation of Yellowstone hot spot. Various lavas with PGB geochemical affinities and Dinner Creek Tuff units both cap and underlie the Dooley Mountain rhyolite complex (Fig. 2.11) (Large, 2016). The oldest unit of the Dinner Creek Tuff (unit 1) is exposed beneath the $15.59 \pm 0.04$ Ma base of the Dooley Mountain complex (Hess, 2014). Here, I dated a PGB sample (DM; sample DM255B) that appears to underlie the Dinner Creek Tuff (unit 1), however the sample yields an age plateau of $15.76 \pm 0.11 \mathrm{Ma}$, arguing against the observed stratigraphy. Hence, this lava may not underlie unit 1 of Dinner Creek Tuff but may represent an intra-canyon flow. Near Brogan, Oregon there are sections of multiple basaltic lavas that match PGB composition (Fig. 2.1, 2.11) (Fox, in prep.). These basaltic lavas are similar to the middle and upper subunits of the PGB and a lateral continuity is likely between Dooley Mountain and the PGB of the original extent (Fig. 2.13). 
Further to the northeast, early workers identified basaltic lavas with PGB chemistry below Imnaha lavas at Dug Bar, east of the Wallowa Mountains (Waters, 1961; Bond, 1963; Wright et al., 1973; Baksi and Watkins, 1973; Watkins and Baksi, 1974; Kleck, 1976) (Fig. 2.9). These lavas were originally described as "PGB-type", but never correlated with PGB because of their distance from the type locality (Swanson et al., 1979; Fiebelkorn et al., 1982). Based on the older ages and identification of PGB lavas $>100 \mathrm{~km}$ from the type locality at Picture Gorge, these lavas may be PGB.

Hart Mountain to Succor Creek To the south near Hart Mountain there are multiple open-pit sunstone mines. Sunstones are copper-enriched plagioclase phenocrysts (up to $\sim 10 \mathrm{~cm}, \mathrm{An}_{65}$ to $\mathrm{An}_{72}$ ) found in scattered highly porphyritic basaltic lavas in eastern Oregon (Fig. 2.1; Rossman, 2011). These highly porphyritic basalts were generally considered to be Steens Basalt (Stewart et al., 1966). Basaltic lavas hosting sunstones are found in two primary localities that are $\sim 150 \mathrm{~km}$ apar - near Delintment Lake, Ochoco National Forest, and Plush, near Hart Mountain (Fig. 2.1). Basaltic lavas found in the Ochoco National Forest location, yield whole-rock geochemical data that are equivalent to PGB lavas in the type locality (Fig. 2.11). Basaltic lavas sampled from two mines near Plush, also yield similar whole-rock geochemical results, and suggest basalts with PGB compositions erupted or traveled as far south as Hart Mountain. This is a surprising result as the Hart Mountain area is located well within what was thought to be solely covered by Steens Basalt.

Moving east towards the Oregon-Idaho border, there are multiple mid-Miocene rhyolitic calderas - coeval with the CRBG. Mahogany Mountain and Three Fingers 
caldera of southeastern Oregon have been known as the source for the tuff of Leslie Gulch and tuff of Spring Creek (Vander Meulen et al., 1989) which have recently been argued to represent a single eruptive unit issued from a larger caldera, the Rooster Comb caldera (Mahood and Benson, 2017). On the northeastern margin of this silicic center near Succor Creek, there are some scattered basaltic dikes and associated lava flows. The dikes near Succor Creek are northwest trending and have whole-rock compositions that are a good match for PGB (Fig. 2.11) (Black, in prep.).

\section{DISCUSSION}

\section{Placing Basalts of Extended Distribution into the PGB Stratigraphy}

The PGB internal stratigraphy documented by Bailey (1989a) is based on three subunits in turn subdivided into 17 members which represents observed stratigraphy within the type locality and the original distribution area north of the John Day Valley (Brown \& Thayer, 1966). However, without stratigraphic context many members of the PGB are indistinguishable and difficult to differentiate even with geochemical data. Additionally, Bailey (1989a, b) identified 18 geochemically unique basalt lava flows that were not correlated as one of his PGB members; they were left unassigned and not included in the original stratigraphy.

This compositional ambiguity along with the lack of multiple laterally continuous basalt exposures over the extended PGB distribution area adds challenges when assigning newly identified PGB lavas as a specific subunit or member in the PGB stratigraphy. As I extend distribution of PGB lavas beyond the original distribution, the geochemically 
variability of PGB lavas and dikes also somewhat increases (Fig. 2.9). Despite these uncertainties, newly identified PGB samples were compared to geochemical data of the original PGB stratigraphy using a PCA on geochemical data for 20 total major and trace elements. The results indicate that newly identified PGB samples (this study) best conform to the lower and upper subunits of the PGB, the Twickenham and Dayville Basalts, respectively and only a limited number of my PGB samples have similarities to members in the middle subunit within the PGB stratigraphy (Monument Mountain) (Fig. 2.8). It should be noted though that some of the newly identified PGB flows in this study may represent unassigned flows that were not represented in the stratigraphic section of Bailey (1989a).

\section{Basalt of Malheur Gorge}

Over $100 \mathrm{~km}$ southeast of Picture Gorge, the Malheur Gorge has been highlighted as a key area for demonstrating stratigraphic relationships among Steens, Imnaha, and Grande Ronde Basalt members of the CRBG (Hooper et al., 2002; Camp et al., 2003). In light of the discovery that PGB lavas reach into the Malheur Gorge area as well, it is worthwhile to review data that allowed for correlation of lavas of the basalt of Malheur Gorge, divided into lower, upper Pole Creek lavas, Birch Creek lavas, and Hunter Creek Basalt, with specific main phase CRBG units. The interpretation that all lower Pole Creek lavas of the basalt of Malheur Gorge are correlative to Steens Basalt is based on XRF data from Binger (1997). Comparing the current geochemical data on Steens Basalt and PGB to data on the Pole Creek basalts of Binger (1997), raises questions about the robustness of the original correlations (Fig. 2.12). In fact, many geochemical plots using 
both major and trace element data illustrate a considerable overlap of Binger's data with PGB and Steens Basalt, the degree of overlap with either CRBG unit varies depending on plot (Fig. 2.12). This indicates that PGB may not be solely restricted to the very western end of Malheur Gorge, as presented above, but PGB lavas may be present throughout Malheur Gorge. However, current data are insufficient to fully confirm this. On the other hand, these data sets demonstrate that all lower Pole Creek lavas cannot be assigned as Steens Basalt.

\section{Eruptive Locations: Proximal and Distal}

The original distribution of the PGB was limited to the type locality at Picture Gorge and surroundings, and no lavas were found to extend southward of the John Day Valley (Fig. 2.1). My field and geochemical data indicate basaltic lavas and dikes of the PBG extend well beyond the current distribution and covered a larger areal extent with a greater volume of material erupted. Although outcrops are not laterally continuous, lavas of the PGB occur over $100 \mathrm{~km}$ from the previously mapped extent and thus must have flowed a considerable distance subaerially $(>150 \mathrm{~km})$. On the other hand, lavas with PGB-like geochemistry that occur most distally to the Monument dike swarm (i.e., Hart Mountain, Succor Creek, Dug Bar, and possibly Brogan) may have erupted locally. For PGB-like lavas of the Brogan area and of Succor Creek, there is field evidence that supports local eruptions (Fox, in prep; Black, in prep., respectively). This revised spatial extent is based on inferences of whether these PGB lavas are sourced from local eruptions, or the result of lavas that traveled a substantial distance. Based on these 
interpretations, I drew envelops to connect lavas from far travelled flows back to the likely eruption site (Fig. 2.13).

\section{Revised Areal Extent and Volume}

In combination with geochronological and geochemical data, revised area and volume estimates for the PGB are calculated using locations of newly identified mid Miocene lavas (Table 2.3). These newly identified flows reflect PGB compositions and connect back to eruption sites within the Monument dike swarm Furthermore, by geochemically correlating PGB lavas of extended distribution with PBG subunits I revise the distribution of each subunit (Fig. 2.13). Based on ages and geochemical similarities, I find that the majority of PGB flows and dikes in the extended distribution represent the earliest and latest PGB subunits within the previously defined stratigraphy. Only a few sparse basalts are geochemically similar to the Monument Mountain Basalt in the extended spatial distribution (Fig. 2.8A). This assessment was focused on PGB exposures within the proposed extended distribution, and use previous estimates of PGB distribution to revise the total area and eruptive volume. These results suggest that an area of 14,000 $\mathrm{km}^{2}$ be added to the previous PGB extent of $10,677 \mathrm{~km}^{2}$, yielding a total PGB distribution area of 24,500 $\mathrm{km}^{2}$. My calculated volume for the extended distribution ranges between approximately 1,200 and 5,600 $\mathrm{km}^{3}$, dependent on interpreted thickness and yielding a new total PGB volume between $\sim 3,500$ and $8,000 \mathrm{~km}^{3}$ (Table 2.3). The thickness was calculated as $0.028-0.07 \mathrm{~km}$ represent a low or conservative estimate (the average thickness of a single member within each subunit), ranging up to $0.22 \mathrm{~km}$ at a higher end 
(the overall calculated PGB thickness in the previously mapped extent and reported by Tolan and others (1987)).

\section{Paleogeographic Implications}

Most of the prominent exposures south of the type locality are geochemically similar to the members associated with the youngest stratigraphic PGB subunit, the Dayville Basalts. Conflicting with Bailey's (1989a) finding that the Dayville Basalts are limited to the highest stratigraphic exposures across the original PGB extent, south of the type locality these exposures are predominantly observed at lower elevations. These observations suggest the paleo-topography onto which the PGB lavas erupted just south of the original distribution was different from the one further north and was characterized in the south by uplift concurrently to emplacement of lava flows. Consequently, regional uplift would result in the preferential removal of higher elevation lava flows emplaced before and could have primarily affected the early and middle PGB subunits. This of course would need to be relatively rapid uplift occurring over a timespan of $<0.5 \mathrm{Ma}$.

Finally, the extended PGB distribution includes many locations where lava flows and dikes are exposed over $1 \mathrm{~km}$ higher in elevation than the type locality at Picture Gorge. A likely explanation for this difference is post-emplacement uplift. These observations suggest that the inferred rapid uplift of the Wallowa Mountains immediately following the main-phase of CRBG eruptions (Hales et al., 2005) was more widespread including a corridor from the Wallowa Mountains to the area NW of Burns, and compositionally similar PGB lavas documented as far as Dug Bar and Succor Creek that argue for widespread dispersion of PGB-like lavas. 


\section{Spatial and Temporal Progression of CRBG Eruptions}

It was previously inferred that the extruded volume of each younger CRBG subunit gradually increases, along with the ratio of younger-to-older dikes progressing northward from Steens Mountain to the Chief Joseph dike swarm (Fig. 2.1) (Camp, 1995; Camp and Ross, 2004). These observations coupled with stratigraphic and compositional data (Brandon and Goles, 1988; Geist and Richards, 1993; Camp, 1995; Hooper, 1997; Hooper et al., 2002), have led to the interpretation that CRBG eruptions underwent a progressive south to north migration. This notion has also been supported by the observation of Steens Basalt stratigraphically below Imnaha Basalt in Malheur Gorge (Hooper et al., 2002; Camp et al., 2003). This northward migration of CRBG magmatism became a centerpiece in models that try to explain the origin of CRBG magmatism, either due to a northward opening tear in the slab (Liu and Stegman, 2012), or a progressive peeling-off of the Farallon plate (Camp and Hanan, 2008; Hales et al., 2005). However, there was limited geochronological data to support this northward migration which is now strongly called into question by new age data (this study; Cahoon et al., 2020).

To the contrary of a northward migration, if a progressive migration exists, age data for the PGB suggest a slightly earlier eastern to southeastern migration that started at the Monument dike swarm. Ages for the PGB also suggest eruptive activity was pulsed, as these ages reflect temporal gap of $0.4 \mathrm{Ma}$, between 16.62 ans $16.23 \mathrm{Ma}$ (Fig. 2.8B). This suggests earlier PGB lavas erupted before 16.6 Ma and later lavas extruded after this hiatus at 16.23 Ma (Cahoon et al., 2020). At a minimum, the magmatic footprint of initial CRBG eruptions is widespread from the PGB to the Steens Basalt source areas. This is in 
turn supported by the distribution area of the earliest mid Miocene rhyolites that are cogenetic with CRBG magmatism with ages of rhyolites around $\sim 16.7-16.5$ Ma that outcrop from areas along the Oregon-Nevada state border in the south to near Baker City in the north (Henry et al., 2017; Coble and Mahood, 2016: Streck et al., 2017; Webb et al, 2018). Ascent of the first CRBG magma and initial impingement of the mantle upwelling in the greater Vale area is also consistent with large scale geological and geophysical features that converge there and which are potentially induced by stress imposed on the base of crust due to inception of the Yellowstone plume (Glen and Ponce, 2002) (Fig. 2.13). In this context, the previous observations used in favor of a northward migration could also be the surficial expression of dynamic uplift following arrival of a plume creating a topography that leads to ponding of lavas progressively further north.

\section{CONCLUSIONS}

This study identifies basaltic lavas with PGB composition among previously mapped but unnamed units, or newly discovered basalt lavas and dikes across a wide swath of eastern Oregon. Sampled lava flows and dikes with PGB composition extend this CRBG unit beyond the current mapped extent, eliminating the exposure gap between lavas of PGB, Steens, and Imnaha Basalt, and increasing the total eruptive volume of this continental flood basalt. Combining stratigraphic correlation and geochemical similarities (via PCA) with ${ }^{40} \mathrm{Ar} /{ }^{39} \mathrm{Ar}$ geochronology, the spatial distribution of early and later PGB units is extended. This study more than doubles the previously published PGB distribution area from $10,677 \mathrm{~km}^{2}$ to over $24,000 \mathrm{~km}^{2}$ (Table 2.3). 
Compositional and textural variations between the three subunits of the previously established PGB stratigraphy are useful for classification when considered within the previous mapped distribution of the PGB and in a stratigraphic sequence. However, a detailed reassessment of PGB stratigraphy raises questions on the distinct characteristics of individual members within each subunit as there is significant compositional overlap among members. On the other hand, a loose correlation of PGB lavas from the here extended distribution to previously established PGB subunits can be done based on the variability among PGB members, field observations, and associated geochronological data.

Combining stratigraphic correlation and geochemical similarities, PGB lavas erupted as two discrete pulses across a wide distribution in Oregon. The first pulse occurred as the initial pulse of CRBG eruptive activity (17.23 \pm 0.04 to $16.62 \pm 0.07 \mathrm{Ma})$, and the second erupted contemporaneous with the Grande Ronde Basalt $(16.23 \pm 0.09$ to $15.76 \pm 0.11 \mathrm{Ma}$ ) (Table 1.1). The younger ages corroborate previous field observations of PGB and Grande Ronde Basalt lavas being interstratified (Nathan and Fruchter, 1974). Therefore, it appears that cumulatively PGB lavas erupted for approximately 1.4 million years and throughout the entire activity span of the Grande Ronde Basalt. The wide distribution was likely achieved as PGB lavas traveling further than previously recognized, although local tapping of a similar mantle to produce PGB-like lavas is also plausible. Combining ages, distribution, and geochemistry of lavas with PGB compositions suggests that a shallow depleted but later metasomatized mantle was tapped across Oregon during the earliest and throughout the main phase eruptions of the CRBG. 


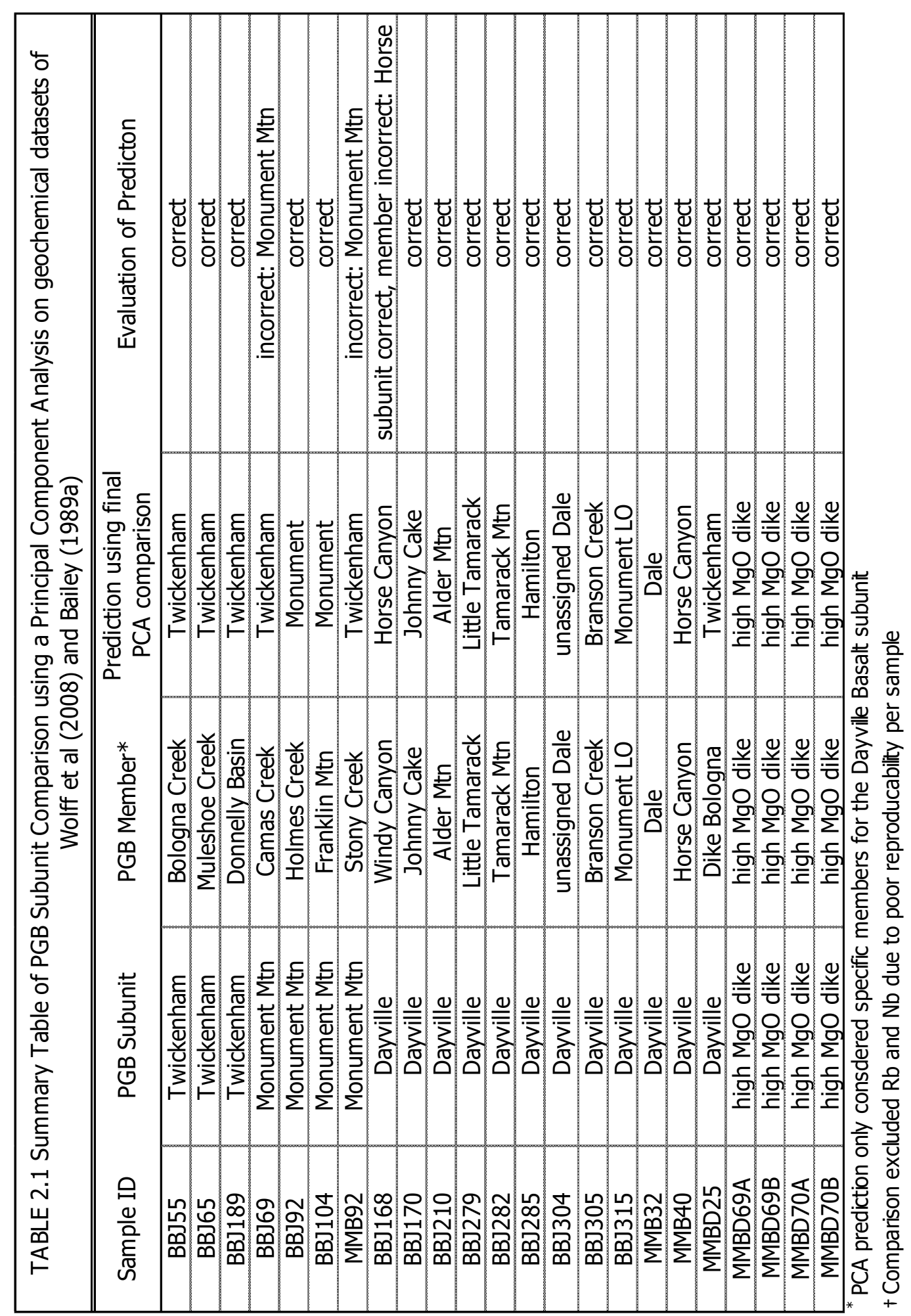




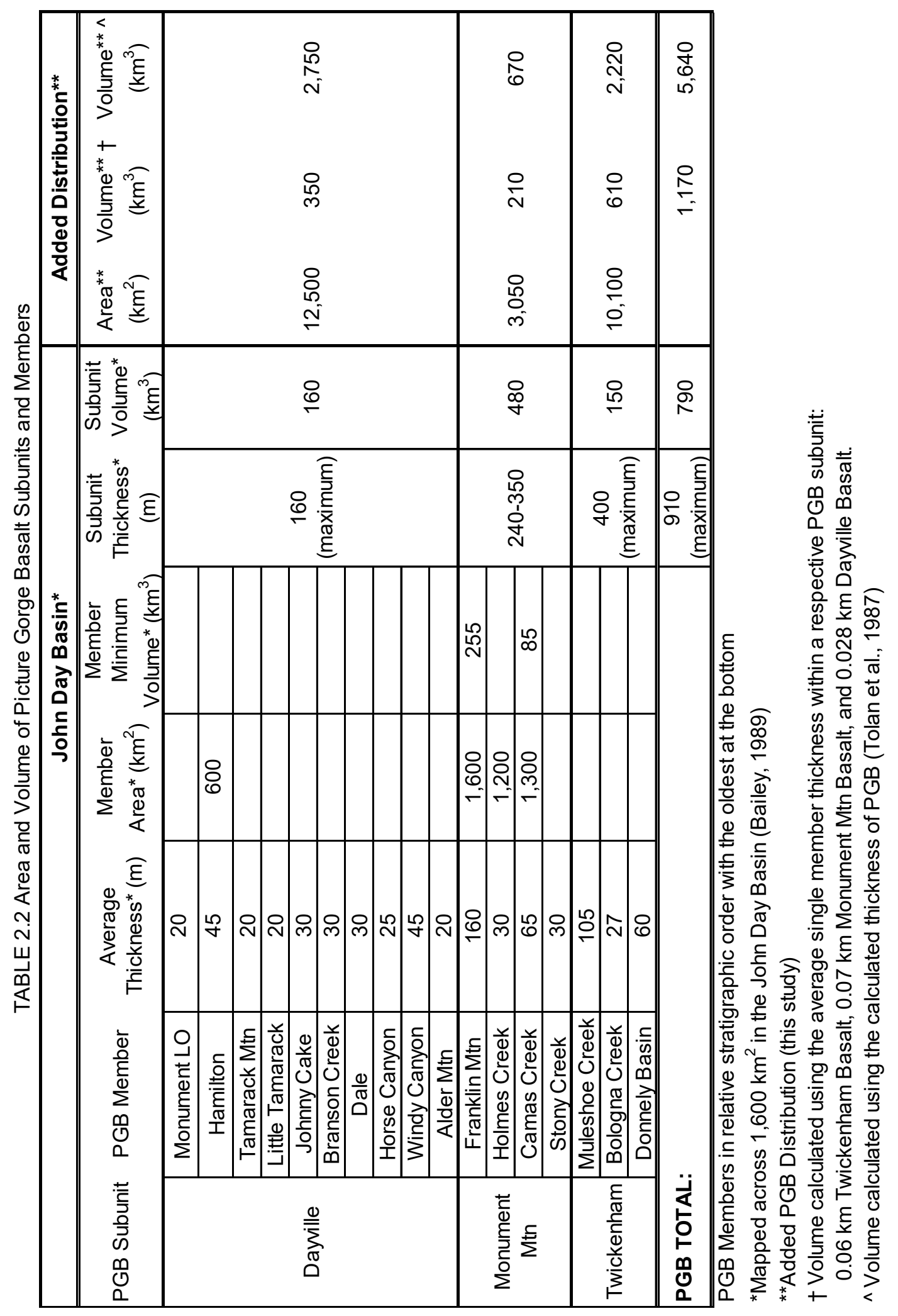


TABLE 2.3 Estimated Area \& Volume for Picture Gorge Basalt

\begin{tabular}{|c|c|c|c|c|}
\hline Region & Source & $\begin{array}{l}\text { Area } \\
\left(\mathrm{km}^{2}\right) \\
\end{array}$ & $\begin{array}{c}\text { Volume } \\
\left(\mathrm{km}^{3}\right)\end{array}$ & $\begin{array}{c}\text { Calculated } \\
\text { Thickness }(\mathrm{km})\end{array}$ \\
\hline John Day Basin & Bailey, 1989 & 1,600 & 790 & 0.49 \\
\hline $\begin{array}{c}\text { John Day Basin \& South } \\
\text { of the Blue Mtns Uplift }\end{array}$ & Bailey, 1989 & 7,500 & 3,300 & 0.44 \\
\hline Mapped PGB Extent & Tolan et al., 1987 & 10,677 & 2,391 & 0.22 \\
\hline \multirow{2}{*}{ Added PGB Distribution } & \multirow{2}{*}{ This study } & \multirow{2}{*}{14,000} & 1,170 (low) & \\
\hline & & & 5,640 (high) & \\
\hline \multirow{2}{*}{ TOTAL: } & & \multirow{2}{*}{24,677} & 3,561 (low) & \\
\hline & & & 8,031 (high) & \\
\hline
\end{tabular}

Low volume uses the thickness of an average member within the respective PGB subunit High volume uses the calculated thickness of PGB (Tolan et al., 1987) 


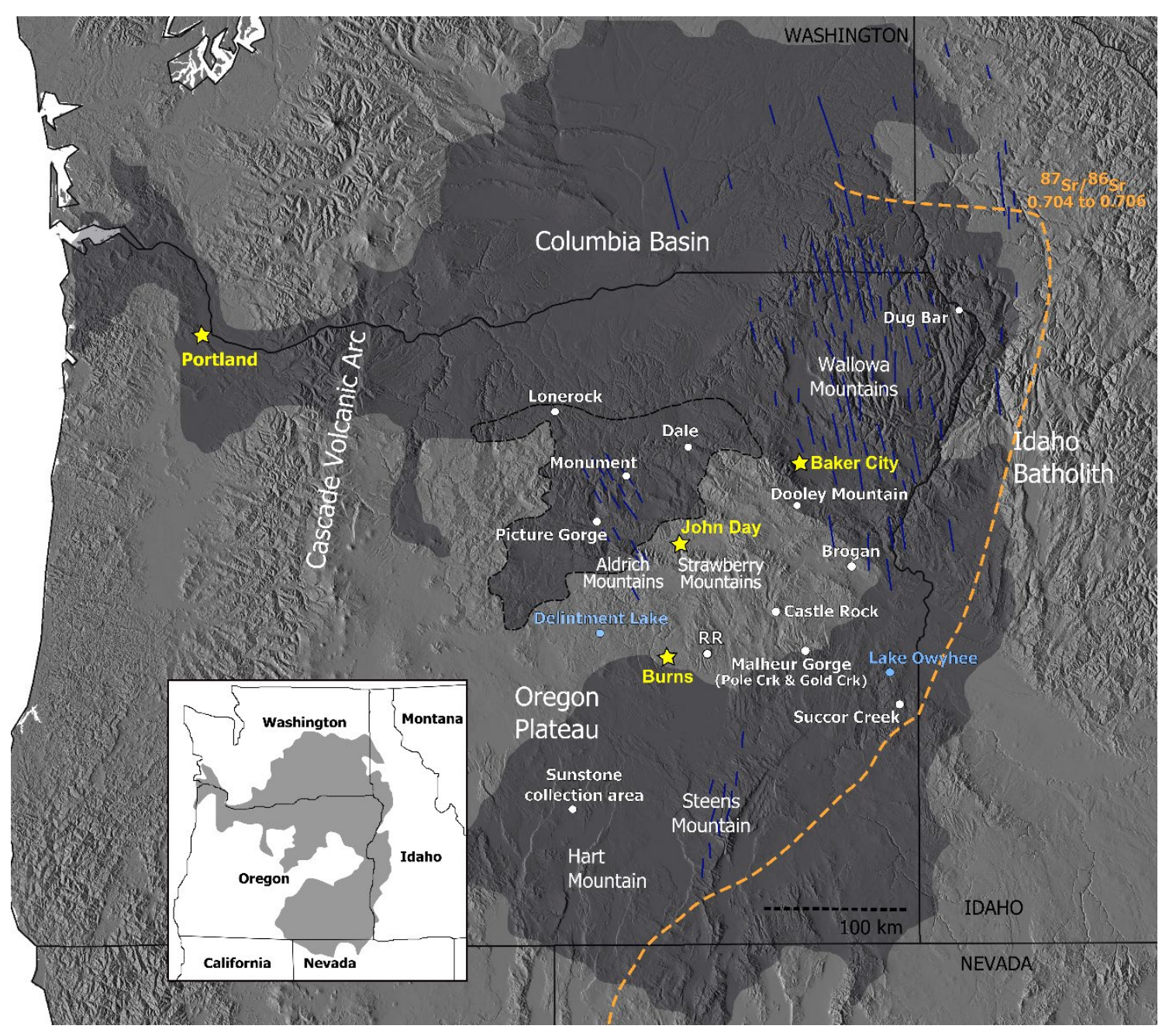

Figure 2.1 Regional map with current extent of the Columbia River Basalt Group (CRBG) with feeder dikes (dark blue lines) and Picture Gorge Basalt, PGB (black dashed outline). Sample location ' $R R$ ' represents Rattlesnake Rd. Dashed 0.704/0.706 line represents the ${ }^{87} \mathrm{Sr} /{ }^{86} \mathrm{Sr}$ contact between accreted terranes and the western margin of the north American craton. Inset map showing distribution of Columbia River Basalt Group in northwestern U.S. with state lines for reference. 


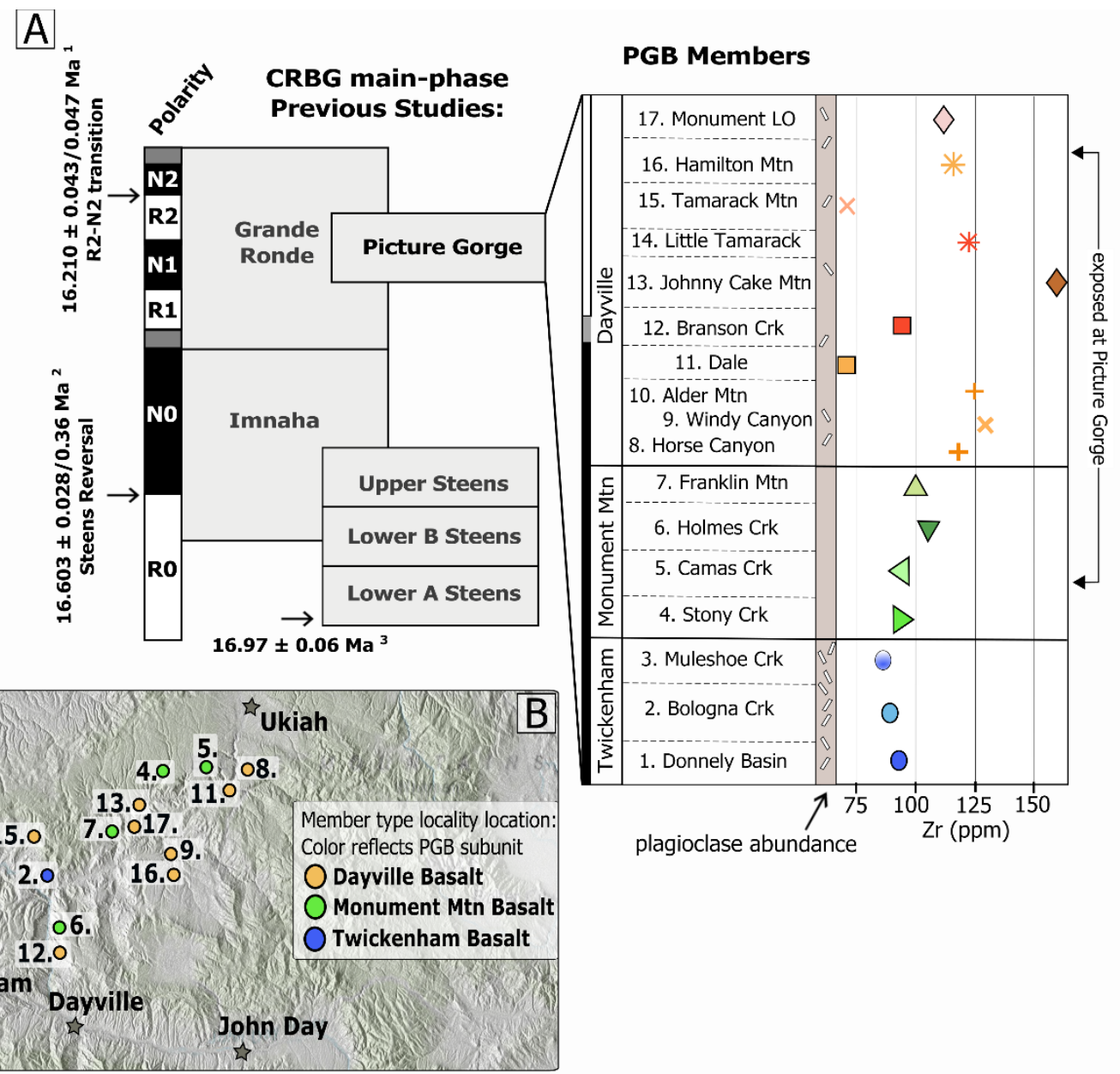

Figure 2.2 (A) Stratigraphy of main-phase CRBG and the PGB highlighting plagioclase content, $\mathrm{MgO}, \mathrm{TiO}_{2}$ (wt. \%), and magnetic orientation of each subunit and respective members of the PGB. Sources of CRBG ages are: ${ }^{1}$ Kasbohm and Schoene (2018), ${ }^{2}$ Mahood and Benson (2017), ${ }^{3}$ Moore, et al. (2018). All ${ }^{40} \mathrm{Ar} /{ }^{39} \mathrm{Ar}$ dates were calculated using Fish Canyon Tuff sanidine age of $28.201 \pm 0.023 \mathrm{Ma}$ after Kuiper et al. (2008), and U-Pb errors for ${ }^{1}$ are reported as $95 \%$ confidence intervals given for internal uncertainty/decay constant uncertainty. (B) Generalized map illustrating type sections of each PGB member and color coded by corresponding PGB subunit. Map modified from Bailey, 1989a. 

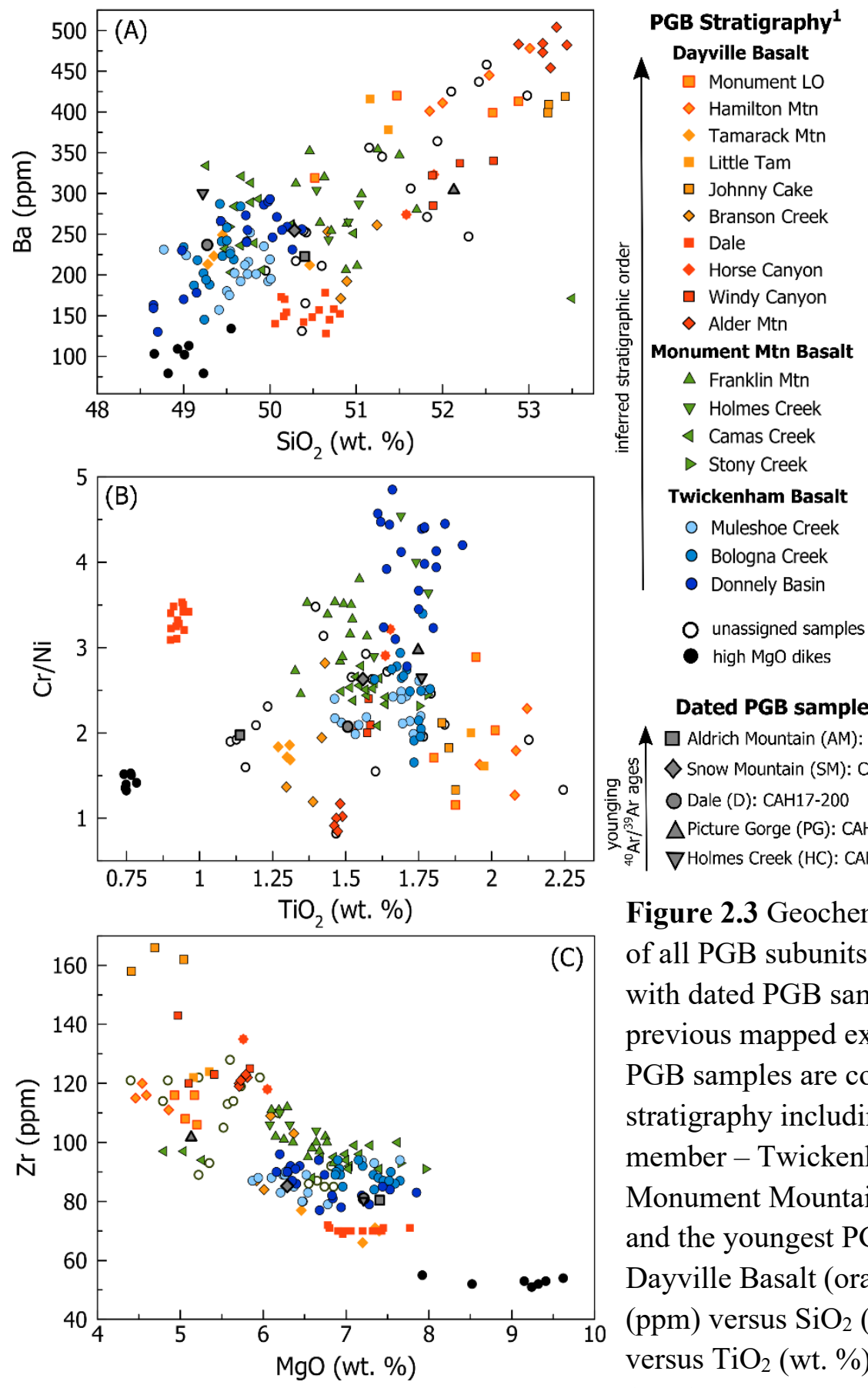

\section{Dated PGB samples ${ }^{2}$}

$\square$ Aldrich Mountain (AM): CAH15-023

$\checkmark$ Snow Mountain (SM): CAH17-174A

O Dale (D): CAH17-200

$\triangle$ Picture Gorge (PG): CAH17-245

$\nabla$ Holmes Creek (HC): CAH17-222A

Figure 2.3 Geochemical variability of all PGB subunits and members, with dated PGB samples from the previous mapped extent. Existing PGB samples are coded by internal stratigraphy including subunit and member - Twickenham Basalt (blue), Monument Mountain Basalt (green), and the youngest PGB subunit the Dayville Basalt (orange). (A) Ba (ppm) versus $\mathrm{SiO}_{2}$ (wt. \%), (B) $\mathrm{Cr} / \mathrm{Ni}$ versus $\mathrm{TiO}_{2}$ (wt. \%), and (C) $\mathrm{Zr}$ (ppm) versus $\mathrm{MgO}$ (wt. \%). ${ }^{1}$

Geochemical data for PGB members from Bailey (1989a). ${ }^{2}$ Geochemical data of dated PGB samples from Cahoon et al (2020). 


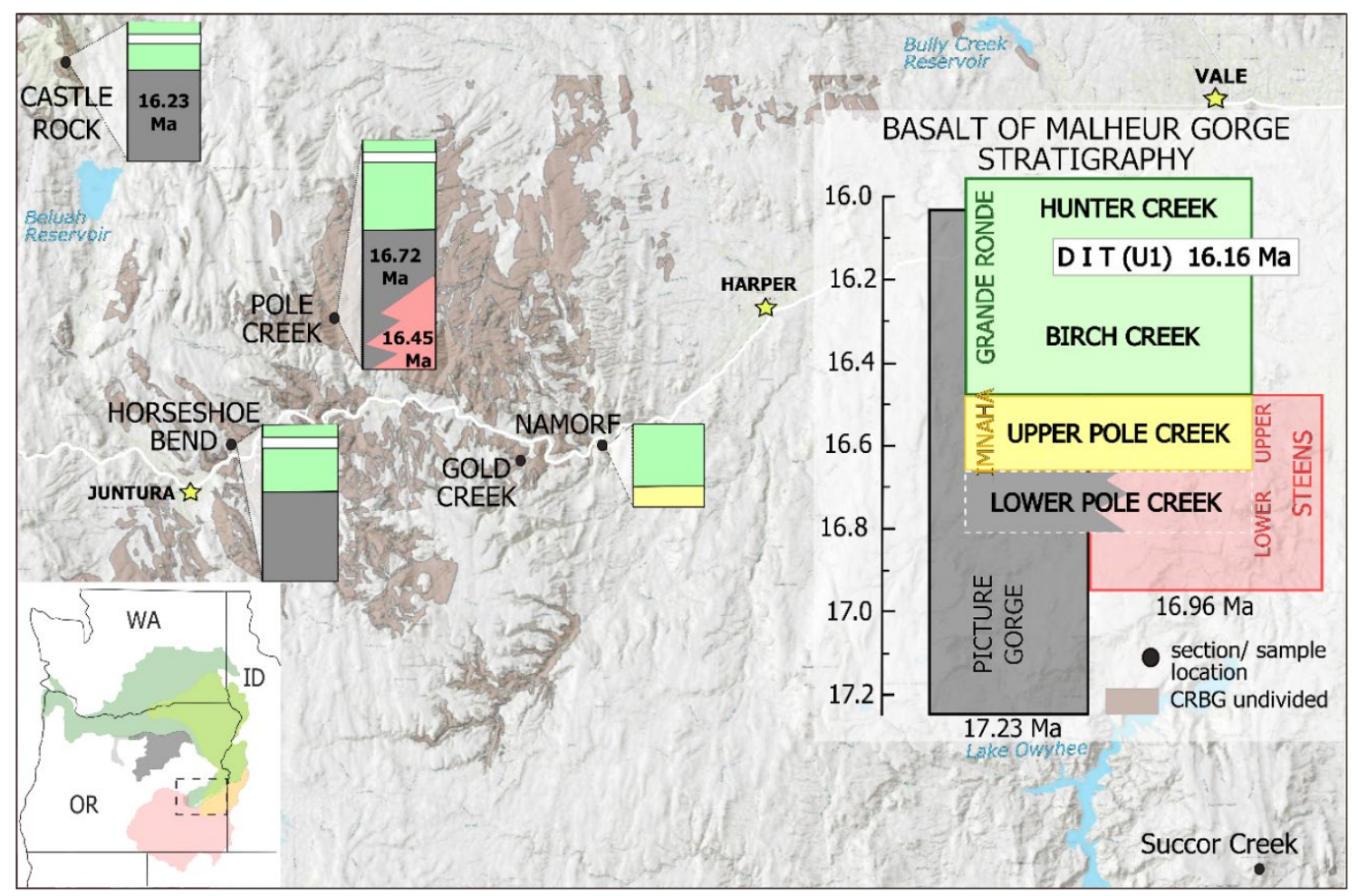

Figure 2.4 Regional Map of Malheur Gorge highlighting locations of stratigraphic sections and interpretation of local basalt correlation to main-phase CRBG units. Stratigraphic relationships are based on field relationships, age, and geochemical data (Camp et al., 2003; Hooper et al., 2002). Ages for the PGB from Cahoon et al. (2020), and Steens Basalt from Jarboe et al. (2010). 


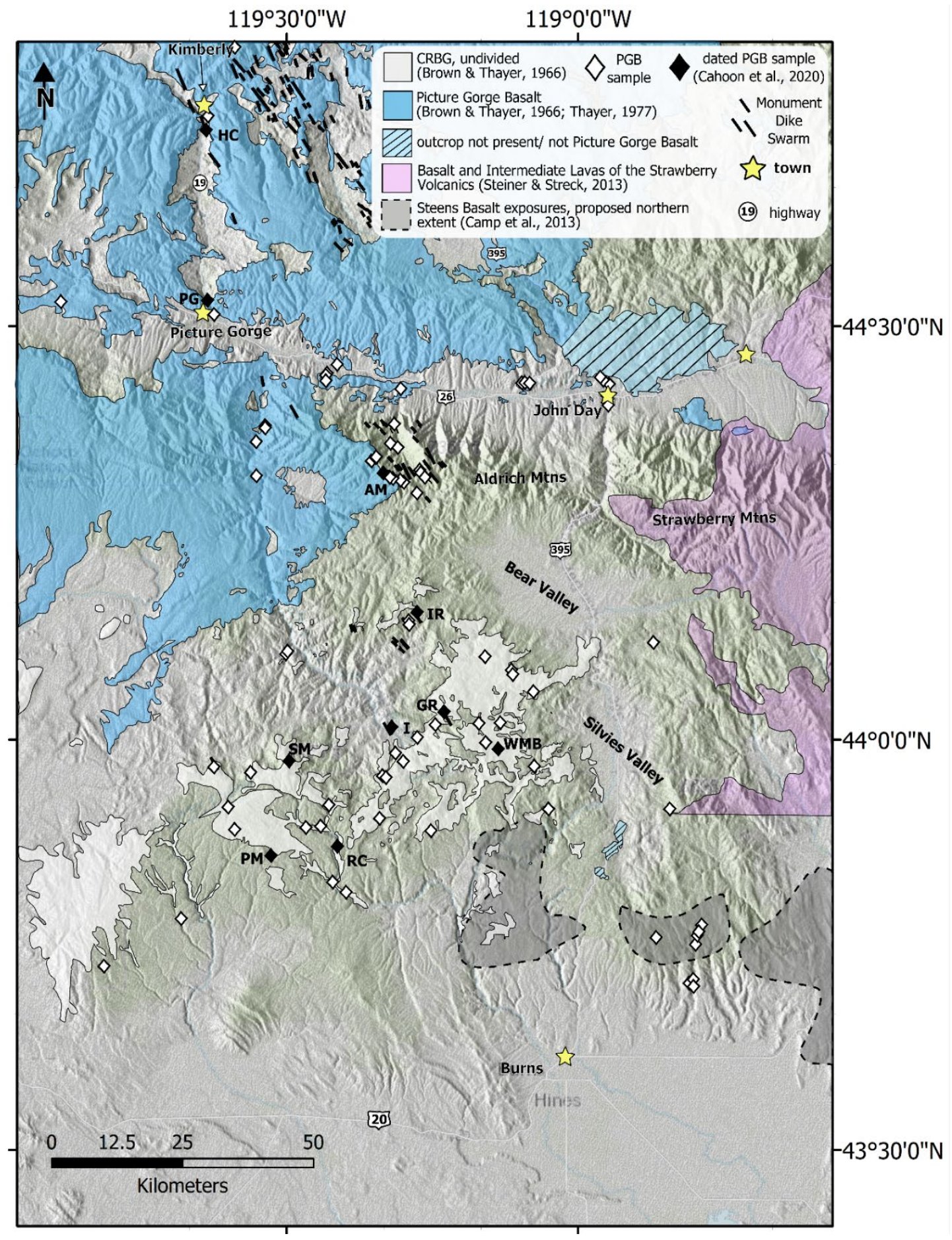

Figure 2.5 Distribution of basaltic lavas south of the type locality of Picture Gorge and the John Day Valley. Many of these undivided mid-Miocene basaltic lavas are geochemically identifiable as PGB (see text for details). Shown for reference are locations of dated samples from Cahoon et al (2020). 


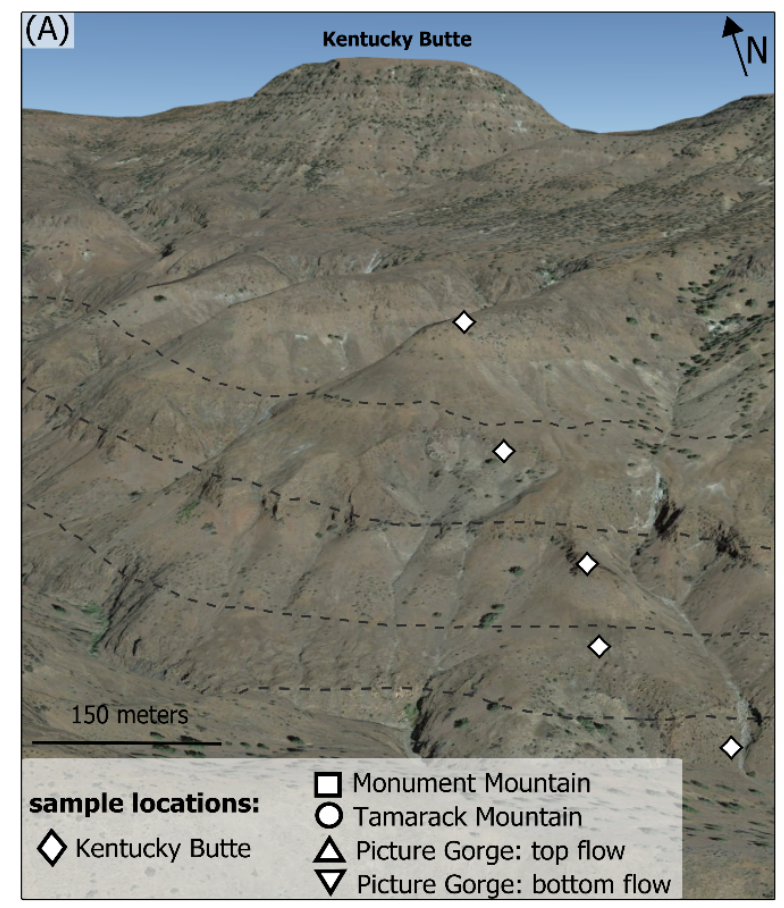

Figure 2.6 (A) Stratigraphic Section at Kentucky Butte with geochemical plots (B) $\mathrm{Cr} / \mathrm{Ni}$ versus $\mathrm{MgO}$ (wt. \%) and (C) $\mathrm{Zr}(\mathrm{ppm})$ versus $\mathrm{TiO}_{2}$ (wt. \%) illustrating the correlation of these basaltic flows to the Twickenham Basalt subunit, the earliest PGB subunit. Also shown for comparison are samples from the uppermost lava flow at Monument Mountain, Tamarack Mountain, and the type locality Picture Gorge.

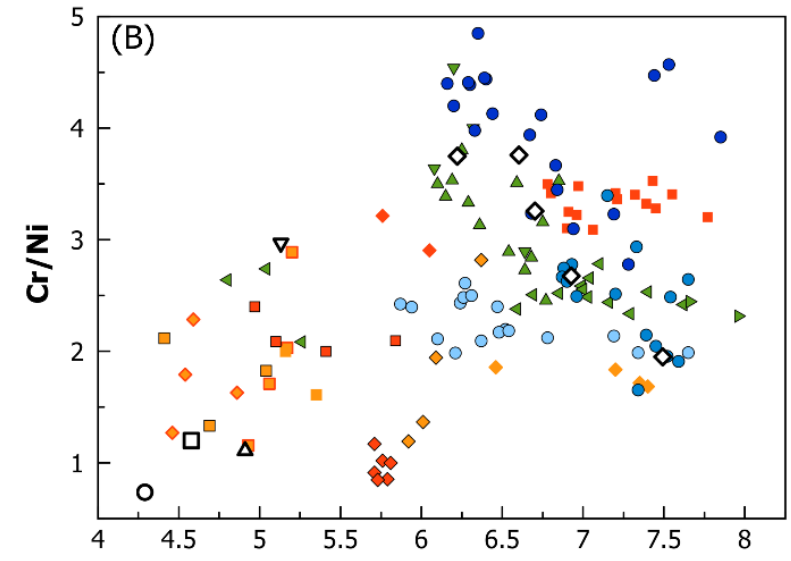
PGB Stratigraphy ${ }^{1}$ Dayville Basalt
$\square$ Monument LO
$\diamond$ Hamilton Mtn
- Tamarack Mtn
- Little Tam
口 Johnny Cake
$\diamond$ Branson Creek
- Dale
- Horse Canyon
Windy Canyon
$\diamond$ Alder Mtn

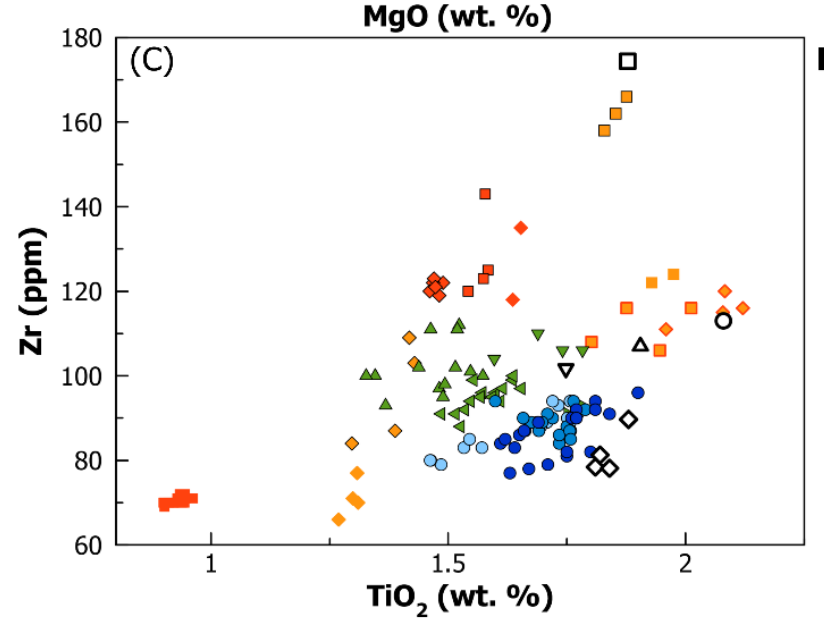

Monument Mtn Basalt

$\triangle$ Franklin Mtn

$\nabla$ Holmes Creek

$\triangleleft$ Camas Creek

$\triangleright$ Stony Creek

Twickenham Basalt

○ Muleshoe Creek

- Bologna Creek

- Donnely Basin 


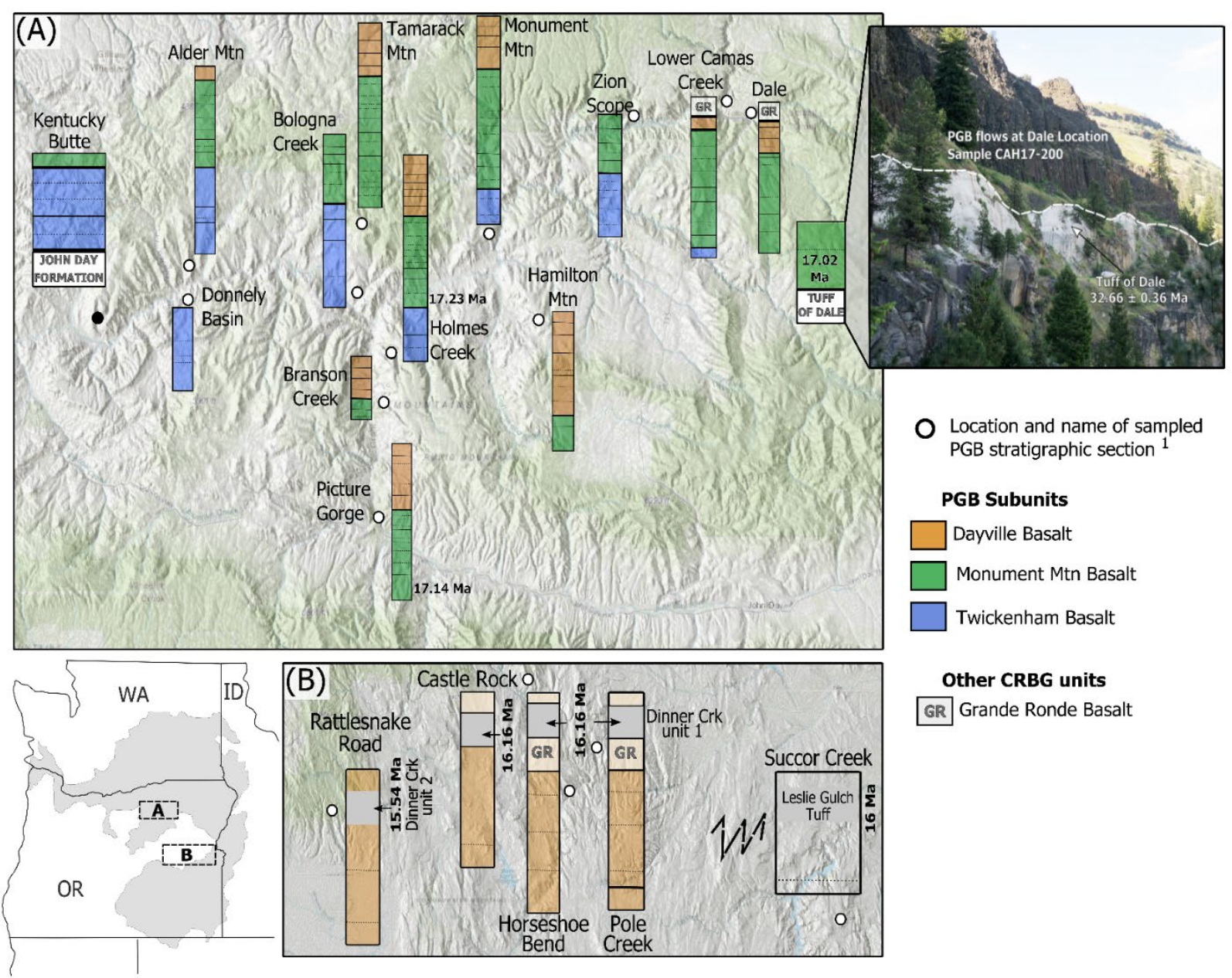

Figure 2.7 Fence diagram illustrating the thickness of each PGB subunit across (A) the original mapped distribution area with our added ages and (B) our added distribution as far east as Succor Creek. ${ }^{1}$ Stratigraphic sampling and identification of PGB subunits by Bailey (1989a). 


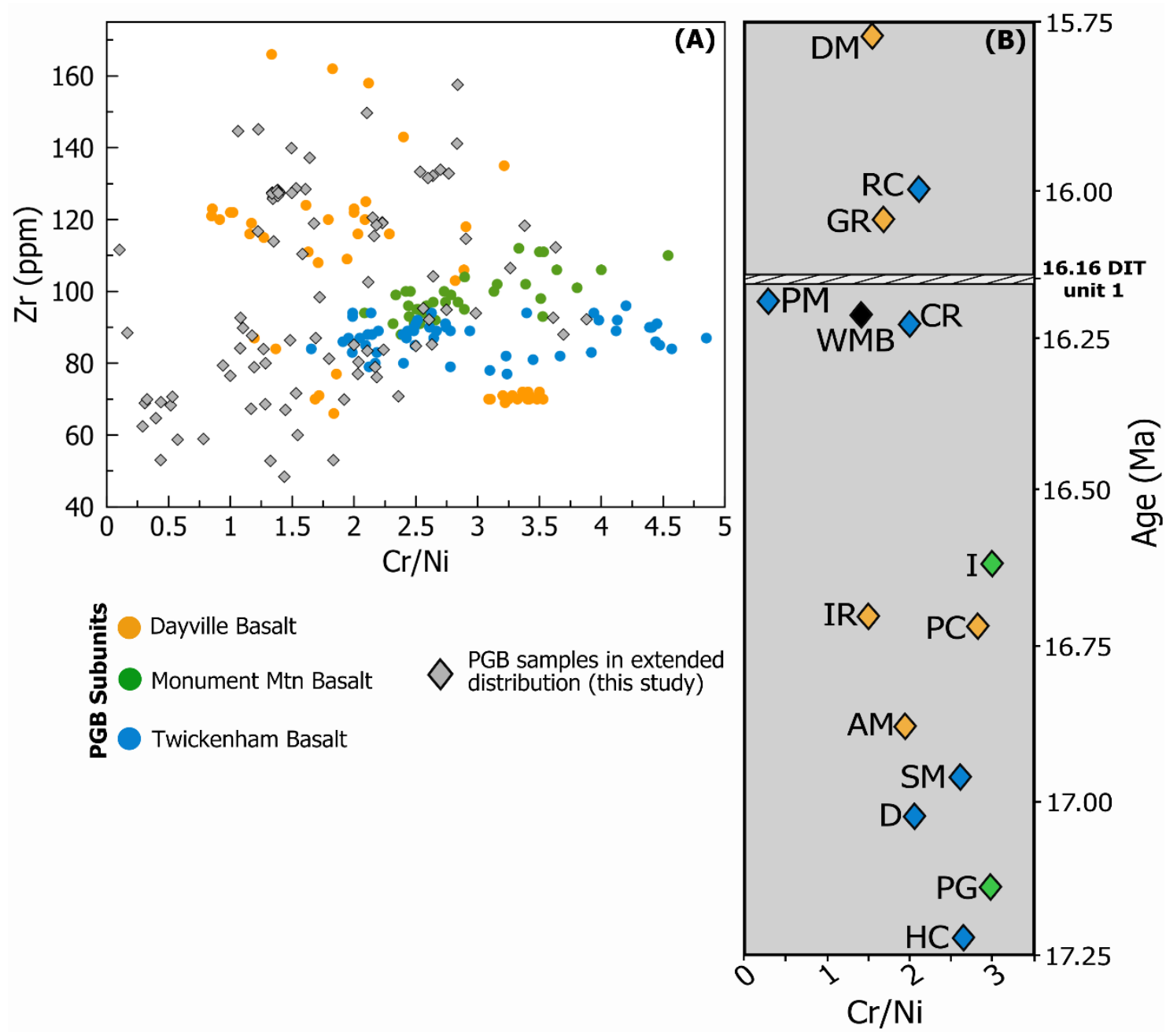

Figure 2.8 (A) Zr versus Cr/ Ni scatterplot of PGB samples from our added distribution compared to the three PGB subunits. (B) Stratigraphic column of dated PGB samples highlighting subunit the sample represents and the $\mathrm{Cr} / \mathrm{Ni}$ value with respect to age. 

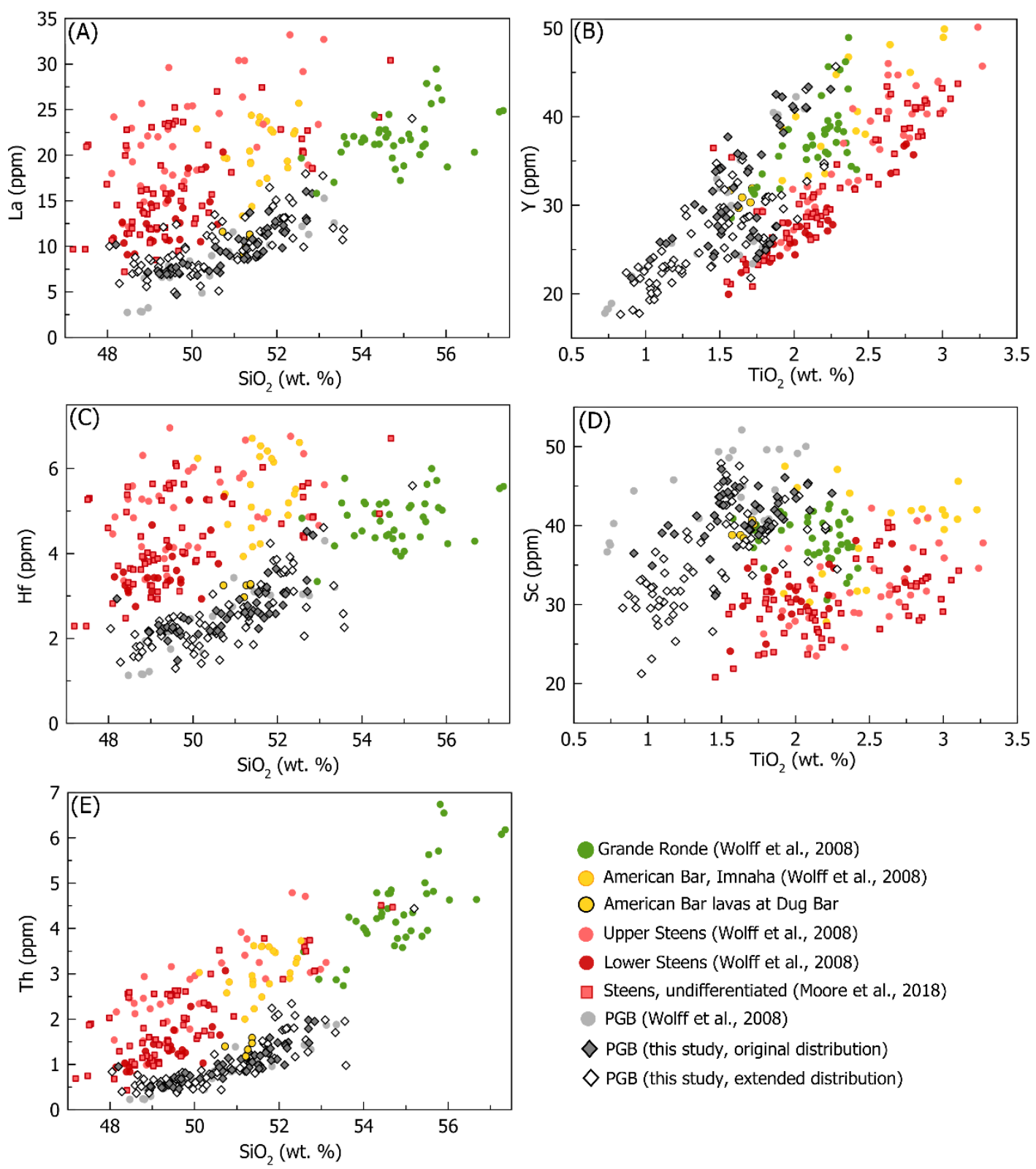

Grande Ronde (Wolff et al., 2008)

American Bar, Imnaha (Wolff et al., 2008)

O American Bar lavas at Dug Bar

- Upper Steens (Wolff et al., 2008)

- Lower Steens (Wolff et al., 2008)

$\square$ Steens, undifferentiated (Moore et al., 2018)

- PGB (Wolff et al., 2008)

$\diamond P G B$ (this study, original distribution)

$\diamond \mathrm{PGB}$ (this study, extended distribution)

Figure 2.9 Geochemistry of PGB samples from this study compared to data from Moore et al., (2018) of Steens Basalt and from Wolff and Ramos (2008) for Steens, Imnaha, Grande Ronde, and PGB of the main-phase CRBG units. PGB samples from this study are subdivided based on their location in the previous mapped extent of the PGB, or our added distribution. For the Imnaha Basalt only American Bar subgroup samples are plotted as only these Imnaha lavas occur in the study area of northeastern Oregon. Imnaha lavas at Dug Bar are highlighted for their geochemical similarity to the PGB. (A) La (ppm) versus $\mathrm{SiO}_{2}$ (wt. \%), (B) Y (ppm) versus $\mathrm{TiO}_{2}$ (wt. \%), (C) $\mathrm{Hf}$ (ppm) versus $\mathrm{SiO}_{2}$ (wt. \%), (D) $\mathrm{Sc}$ (ppm) versus $\mathrm{TiO}_{2}$ (wt. \%), and (E) Th (ppm) versus $\mathrm{SiO}_{2}$ (wt. \%). 

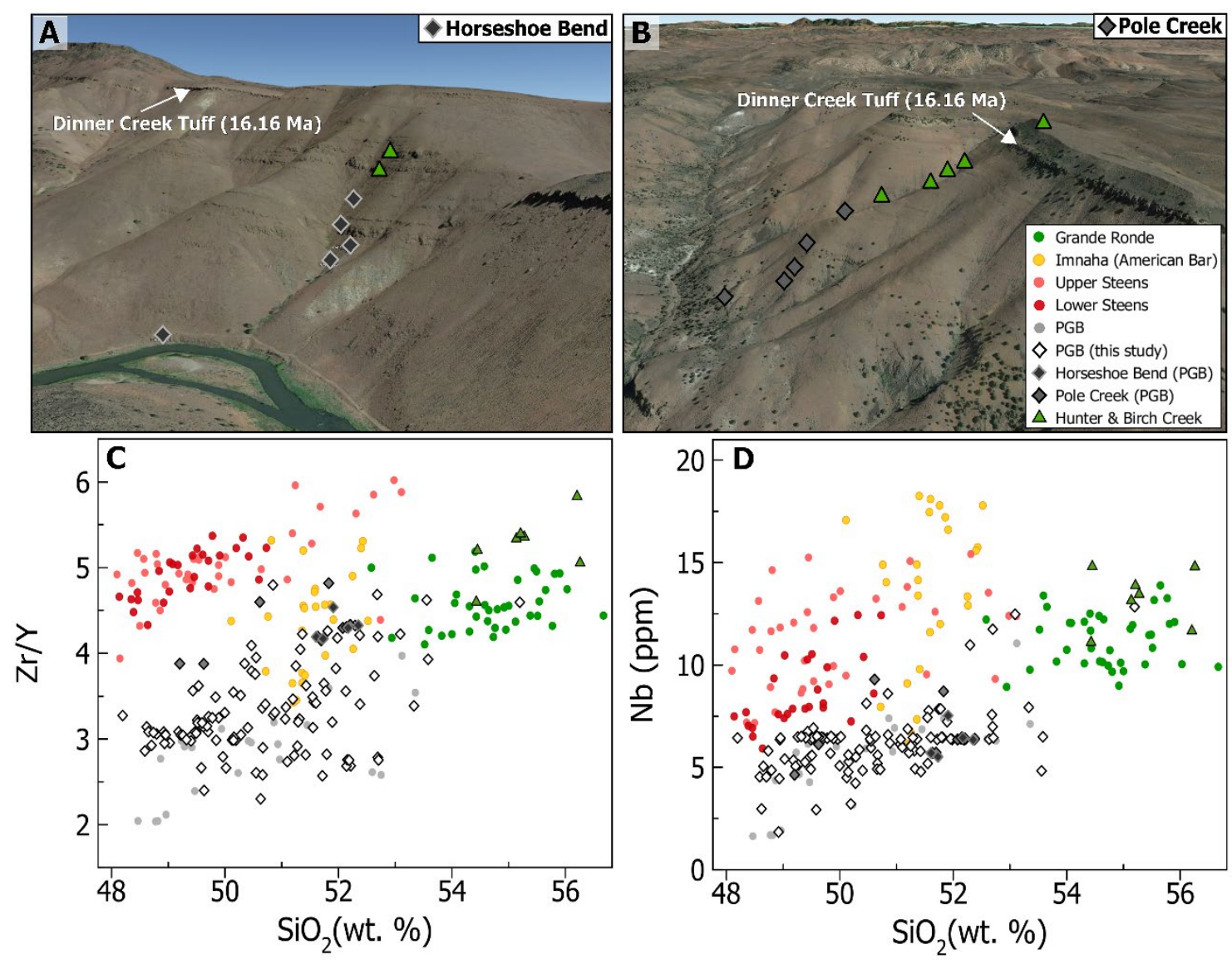

Figure 2.10 Photographs of basalt lava flows in the Malheur Gorge at (A) Horseshoe Bend and (B) Pole Creek with sample locations marked along walked transects. Geochemical data of basaltic samples lavas along transects at Horseshoe Bend and Pole Creek compared to CRBG main-phase units and our samples of Hunter and Birch Creek basalt include (C) $\mathrm{Zr} / \mathrm{Y}$ versus $\mathrm{SiO}_{2}$ (wt. \%) and (D) $\mathrm{Nb}$ (ppm) versus $\mathrm{SiO}_{2}$ (wt. \%). 

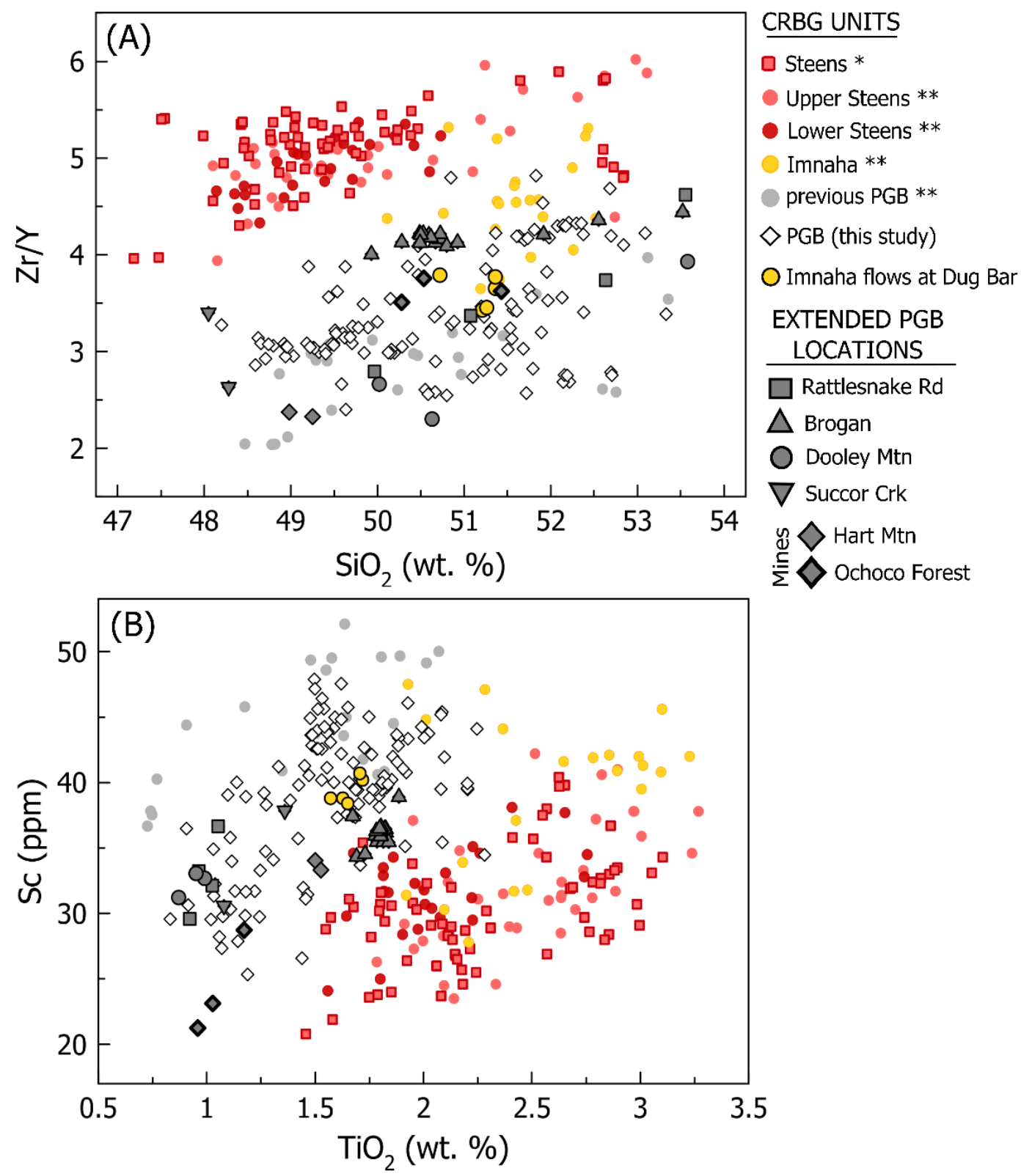

Figure 2.11 Main-phase CRBG geochemistry and multiple PGB samples highlighted from specific locations in the extended distribution. Both mine locations are denoted by "Mines". (A) $\mathrm{Zr} / \mathrm{Y}$ versus $\mathrm{SiO}_{2}$ (wt. \%) and (B) $\mathrm{Sc}$ (ppm) versus $\mathrm{TiO}_{2}$ (wt. \%). 


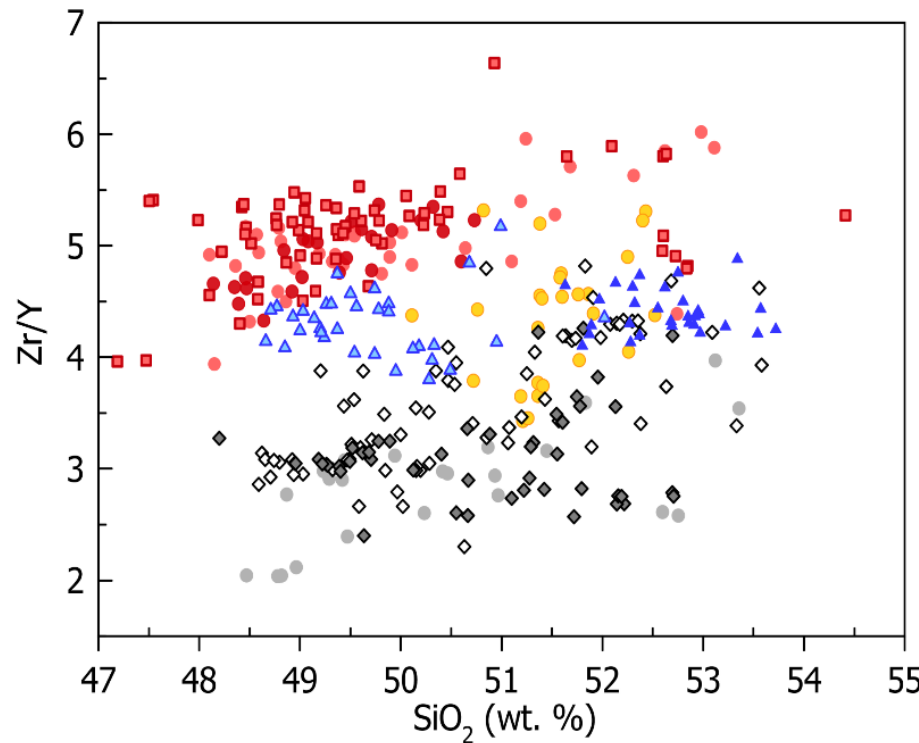
A Upper Pole Creek (Binger, 1997)
$\triangle$ Lower Pole Creek (Binger, 1997)
American Bar, Imnaha (Wolff et al., 2008)
- Upper Steens (Wolff et al., 2008)
- Lower Steens (Wolff et al., 2008)
$\square$ Steens, undifferentiated (Moore et al., 2018)
- PGB (Wolff et al., 2008)
$\diamond$ PGB (this study, original distribution)
$\diamond$ PGB (this study, extended distribution)

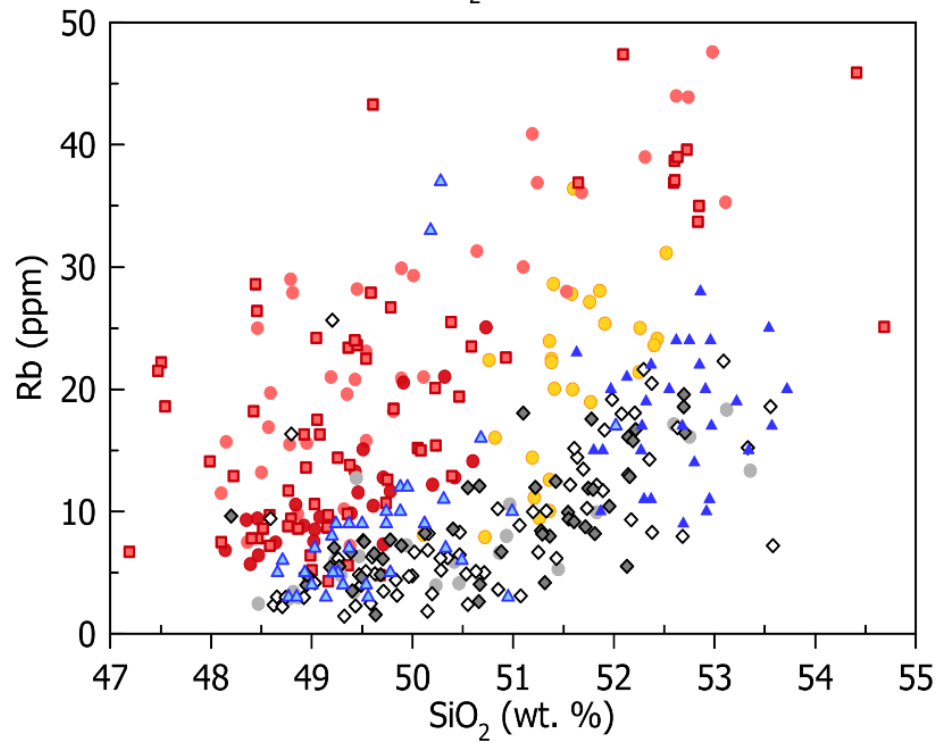

Figure 2.12 Geochemical comparison of lower and upper Pole Creek basalt and main-phase CRBG units. Pole Creek geochemical data from Binger (1997), Imnaha Basalt data from Wolff et al. (2008), Steens Basalt data from Wolff et al. (2008) and Moore et al., (2018). 


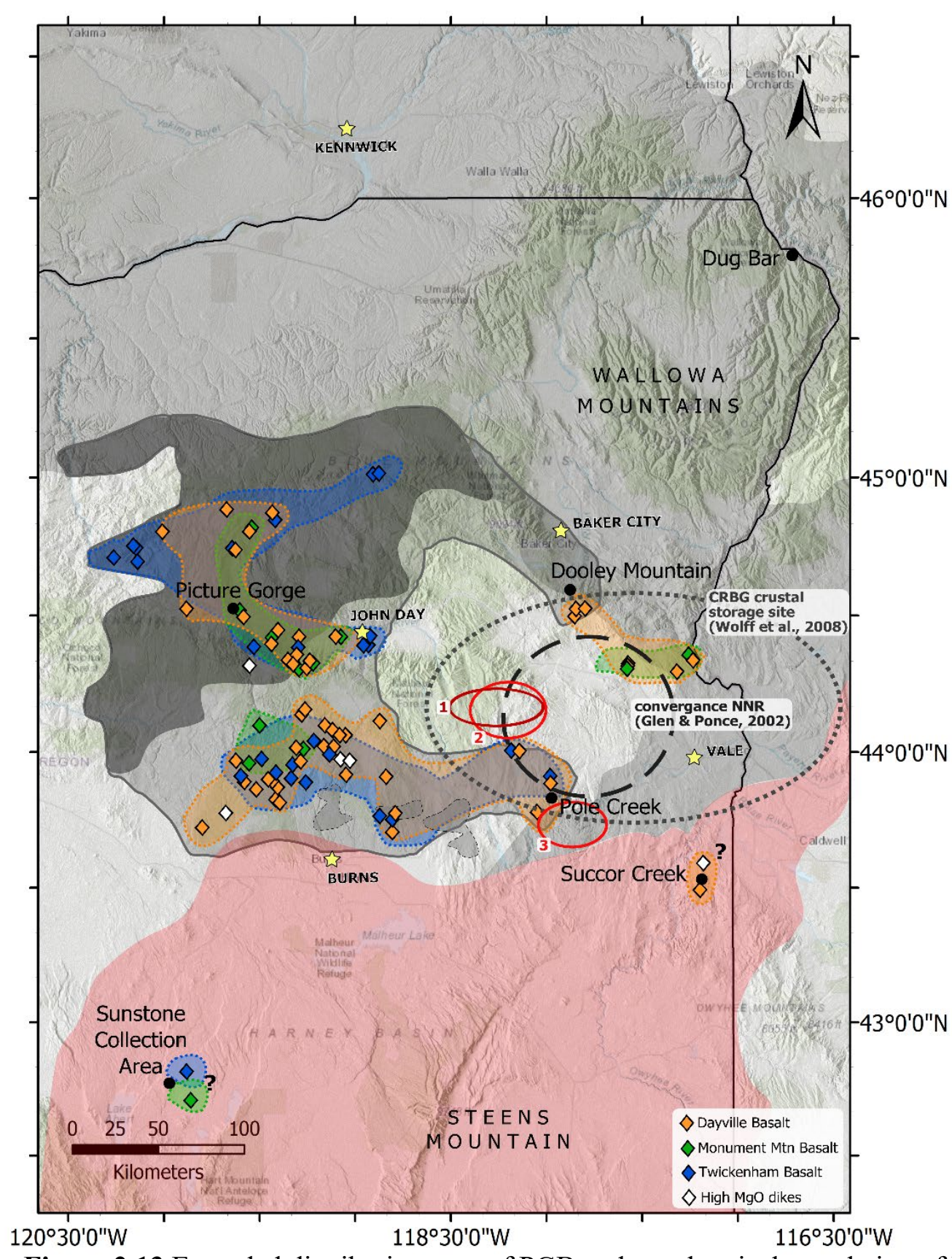

Figure 2.13 Extended distribution map of PGB and geochemical correlation of PGB samples to subunits. Newly proposed PGB area and volume calculated using extended distribution of each PGB subunit that did not overlap with the original mapped distribution (dark grey). The larger polygon encompassing all newly proposed locations (grey) is a the more likely extent to include all PGB lava flows and dikes. The ellipsoids (dashed outline) represent inferred crustal storage sites for CRBG magmas (Wolff et al., 2008) and the location of structural convergence from the Northern Nevada Rift faults (Glen and Ponce, 2002). The ellipsoids (solid outline) depict: ${ }^{1}$ source area of Dinner Creek Tuff eruptive center (Streck et al., 2015); and ${ }^{2,3}$ inferred storage locations for Grande Ronde Basalt (Webb et al., 2018). 


\section{REFERENCES}

Bailey, M.M., 1989a. Revisions to stratigraphic nomenclature of the Picture Gorge Basalt Subgroup, Columbia River Basalt Group. Volcanism and tectonism in the Columbia River flood-basalt province: Geological Society of America Special Paper, 239, pp.67-84.

Bailey, M.M., 1989b. Evidence for magma recharge and assimilation in the Picture Gorge basalt subgroup, Columbia River basalt group. Volcanism and tectonism in the Columbia River flood-basalt province: Geological Society of America Special Paper, 239, pp.343-355.

Baksi, A.K. and Watkins, N.D., 1973. Volcanic production rates: comparison of oceanic ridges, islands, and the Columbia Plateau basalts. Science, 180(4085), pp.493-496.

Baksi, A.K., 2013. Timing and duration of volcanism in the Columbia River Basalt Group: A review of existing radiometric data and new constraints on the age of the Steens through Wanapum Basalt extrusion. Geological Society of America Special Papers, 497, pp.67-85.

Baldwin, E.M., 1973. Geology and mineral resources of Coos County, Oregon (Vol. 80). Barry, T.L., Kelley, S.P., Reidel, S.P., Camp, V.E., Self, S., Jarboe, N.A., Duncan, R.A., Renne, P.R., Ross, M.E., Wolff, J.A. and Martin, B.S., 2013. Eruption chronology of the Columbia River Basalt Group. The Columbia River Flood Basalt Province: Geological Society of America Special Paper, 497, pp.45-66.

Bentley, R.D. and Cockerham, R.S., 1973. The stratigraphy of the Picture Gorge Basalt (PGB), northcentral Oregon: Geol. Soc. America Abs. with Programs, 5(1), p.9. 
Binger, G.B., 1997, The volcanic stratigraphy of the Juntura region, eastern Oregon [M.S. thesis]: Pullman, Washington State University, 206 p.Bond, J.G., 1963. Geology of the Clearwater embayment (No. 128). Bureau of Mines and Geology.

Bond, J.G., 1963, Geology of the Clearwater embayment: Idaho Bureau of Mines and Geology: Pamphlet 128, 83 p.

Brandon, A.D. and Goles, G.G., 1988. A Miocene subcontinental plume in the Pacific Northwest: Geochemical evidence. Earth and Planetary Science Letters, 88(3-4), pp.273-283.

Brandon, A.D., Hooper, P.R., Goles, G.G. and Lambert, R.S.J., 1993. Evaluating crustal contamination in continental basalts: the isotopic composition of the Picture Gorge Basalt of the Columbia River Basalt Group. Contributions to Mineralogy and Petrology, 114(4), pp.452-464.

Brown, C.E. and Thayer, T.P., 1966. Geologic map of the Canyon City quadrangle, northeastern Oregon. The Survey.

Brown, E.A., 2017. Rhyolite Petrogenesis at Tower Mountain Caldera, OR (Masters thesis, Portland State University).

Cahoon, E.B., Streck, M.J., Koppers, A.A. and Miggins, D.P., 2020. Reshuffling the Columbia River Basalt chronology—Picture Gorge Basalt, the earliest-and longesterupting formation. Geology, 48(4), pp.348-352.

Camp, V.E., 1995. Mid-Miocene propagation of the Yellowstone mantle plume head beneath the Columbia River basalt source region. Geology, 23(5), pp.435-438.

Camp, V.E., 2019. Plume-modified mantle flow in the northern Basin and Range and southern Cascadia back-arc region since ca. 12 Ma. Geology. 
Camp, V.E., Ross, M.E. and Hanson, W.E., 2003. Genesis of flood basalts and Basin and Range volcanic rocks from Steens Mountain to the Malheur River Gorge, Oregon. Geological Society of America Bulletin, 115(1), pp.105-128.

Camp, V.E. and Ross, M.E., 2004. Mantle dynamics and genesis of mafic magmatism in the intermontane Pacific Northwest. Journal of Geophysical Research: Solid Earth, 109(B8).

Camp, V.E. and Hanan, B.B., 2008. A plume-triggered delamination origin for the Columbia River Basalt Group. Geosphere, 4(3), pp.480-495.

Camp, V.E., Reidel, S.P., Ross, M.E., Brown, R.J. and Self, S., 2017. Field-trip guide to the vents, dikes, stratigraphy, and structure of the Columbia River Basalt Group, eastern Oregon and southeastern Washington (No. 2017-5022-N, pp. 1-88). US Geological Survey.

Carlson, R.W., Lugmair, G.W. and Macdougall, J.D., 1981. Columbia River volcanism: the question of mantle heterogeneity or crustal contamination. Geochimica et Cosmochimica Acta, 45(12), pp.2483-2499.

Carlson, R.W., 1984, Isotopic constraints on Columbia River flood basalt genesis and the nature of the subcontinental mantle. Geochimica et Cosmochimica Acta, v. 48, p. 2357-2372.

Coble, M.A. and Mahood, G.A., 2016. Geology of the High Rock caldera complex, northwest Nevada, and implications for intense rhyolitic volcanism associated with flood basalt magmatism and the initiation of the Snake River Plain-Yellowstone trend. Geosphere, 12(1), pp.58-113. 
Coffin, M.F., and Eldholm, O., 1994, Large igneous provinces: Crustal structure, dimensions, and external consequences: Reviews of Geophysics, v. 32, p. 1-36.

_2005, Large igneous provinces, in Selley, R.C., Cocks, R., and Plimer, I.R. eds. Encyclopedia of Geology: Oxford, Elsevier, p. 315-323.

Cruz, M., 2017, Field Mapping Investigation and Geochemical Analysis of Volcanic Units within the Dinner Creek Tuff Eruptive Center, Malheur County, Eastern Oregon [Master's Thesis]: Portland State University, 217 p.

Ernst, R.E. and Buchan, K.L., 1997. Giant radiating dyke swarms: their use in identifying pre-Mesozoic large igneous provinces and mantle plumes. GEOPHYSICAL MONOGRAPH-AMERICAN GEOPHYSICAL UNION, 100, pp.297-334.

Ernst, R.E., Buchan, K.L. and Campbell, I.H., 2005. Frontiers in large igneous province research. Lithos, 79(3-4), pp.271-297.

Evans, J.G., 1990, Geology and mineral resources map of the South Mountain quadrangle, Malheur County, Oregon: Oregon Department of Geology and Mineral Industries Geologic Map Series GMS-67, 1 sheet, scale 1:24,000.

Fiebelkorn, R.B., Walker, G.W., MacLeod, N.S., McKee, E.H., and Smith, J.G., 1983, Index to K-Ar determinations for the State of Oregon: Isochron/West, no. 37, p. 360.

Fruchter, J.S. and Baldwin, S.F., 1975. Correlations between dikes of the Monument swarm, central Oregon, and Picture Gorge Basalt flows. Geological Society of America Bulletin, 86(4), pp.514-516.

Geist, D. and Richards, M., 1993. Origin of the Columbia Plateau and Snake River plain: Deflection of the Yellowstone plume. Geology, 21(9), pp.789-792. 
Glen, J.M. and Ponce, D.A., 2002. Large-scale fractures related to inception of the Yellowstone hotspot. Geology, 30(7), pp.647-650.

Goles GG (1986) Miocene basalts of the Blue Mountains province in Oregon: Part 1. Compositional types and their geological settings. J Petrol 27:495 520

Greene, R.C., Walker, G.W. and Corcoran, R.E., 1972. Geologic map of the Burns quadrangle, Oregon (No. 680).

Hales, T.C., Abt, D.L., Humphreys, E.D. and Roering, J.J., 2005. A lithospheric instability origin for Columbia River flood basalts and Wallowa Mountains uplift in northeast Oregon. Nature, 438(7069), pp.842-845.

Hanna, T.R., 2018, Areal extent and volumes of the Dinner Creek Tuff units, eastern Oregon based on lithology, bulk rock composition and feldspar mineralogy [M.S. thesis]: Portland, Oregon, Portland State University, 144 p., https:// doi .org /10 .15760 /etd .6239 .

Henry, C.D., Castor, S.B., Starkel, W.A., Ellis, B.S., Wolff, J.A., Laravie, J.A., McIntosh, W.C. and Heizler, M.T., 2017. Geology and evolution of the McDermitt caldera, northern Nevada and southeastern Oregon, western USA. Geosphere, 13(4), pp.1066-1112.

Hess, E.N., 2014, Strontium, lead, and oxygen isotopic signatures of mid-Miocene silicic volcanism in eastern Oregon [M.S. thesis]: Portland, Oregon, Portland State University, 117 p., https:// doi .org/10 .15760/etd .2077.

Hooper, P.R., 1974. Petrology and chemistry of the Rock Creek flow, Columbia River basalt, Idaho. Geological Society of America Bulletin, 85(1), pp.15-26. 
Hooper, P.R \& Swanson, D.A., 1990. The Columbia River Basalt Group and associated volcanic rocks of the Blue Mountain province. US Geol Survey Prof Pap 1437: 63100.

Hooper, P.R., 1997, The Columbia River flood basalt province: Current status, in Mahoney, J.J., and Coffin, M.F., eds., Large igneous provinces: Continental, oceanic and planetary flood volcanism: American Geophysical Union Geophysical Monograph 100, p. 1-28.

Hooper, P.R., Binger, G.B. and Lees, K.R., 2002. Ages of the Steens and Columbia River flood basalts and their relationship to extension-related calc-alkalic volcanism in eastern Oregon. Geological Society of America Bulletin, 114(1), pp.43-50.

Houston, R.A., McClaughry, J.D., Duda, C.J.M., and Ferns, M.L., 2017. Geologic Map of the Harney 7.5' Quadrangle, Harney County, Oregon.

Isom, S. L. and Streck, M. J., 2017, Geologic Map of the Telephone Butte quadrangle, Oregon: U.S. Geological Survey EdMap, scale 1:24,000, 1 sheet.

Jarboe, N.A., Coe, R.S., Renne, P.R., Glen, J.M. and Mankinen, E.A., 2008. Quickly erupted volcanic sections of the Steens Basalt, Columbia River Basalt Group: Secular variation, tectonic rotation, and the Steens Mountain reversal. Geochemistry, Geophysics, Geosystems, 9(11).

Jarboe, N.A., Coe, R.S., Renne, P.R. and Glen, J.M., 2010. The age of the Steens reversal and the Columbia River Basalt Group. Chemical Geology, 274(3), pp.158-168.

Kasbohm, J. and Schoene, B., 2018. Rapid eruption of the Columbia River flood basalt and correlation with the mid-Miocene climate optimum. Science advances, 4(9) 
Kittleman, L.R., Green, A.R., Hagood, A.R., Johnson, A.M., McMurray, J.M., Russell, R.G., and Weeden, D.A., 1965, Cenozoic stratigraphy of the Owyhee region, southeastern Oregon: University of Oregon Museum of Natural History Bulletin 1, $45 \mathrm{p}$.

Kittleman, L.R., Green, A.R., Haddock, G.H., Hagood, A.R., Johnson, A.M., McMurray, J.M., Russell, R.G., and Weeden, D.A., 1967, Geologic map of the Owyhee region, Malheur County, Oregon: University of Oregon Museum of Natural History Bulletin 8 , scale $1: 125,000$.

Kleck, W.D., 1977. Chemistry, Petrography, and Stratigraphy of the Columbia River Group in the Imnaha River Valley Region, eastern Oregon and western Idaho. (Doctoral dissertation, Washington State University).

Koppers, A.A., 2002. ArArCALC—software for $40 \mathrm{Ar} / 39$ Ar age calculations.

Computers \& Geosciences, 28(5), pp.605-619.

Kuiper, K.F., Deino, A., Hilgen, F.J., Krijgsman, W., Renne, P.R. and Wijbrans, J.R., 2008. Synchronizing rock clocks of Earth history. science, 320(5875), pp.500-504.

Large, A.M., 2016. Silicic Volcanism at the Northern and Western Extent of the Columbia River Basalt Rhyolite Flare-up: Rhyolites of Buchanan Volcanic Complex and Dooley Mountain Volcanic Complex, Oregon (Masters Thesis, Portland State University).

Lees, K.R., 1994, Magmatic and tectonic changes through time in the Neogene volcanic rocks of the Vale area, Oregon, northwestern USA [Ph.D. thesis]: Milton Keynes, UK, The Open University, Department of Earth Sciences, 284 p. 
Liu, L. and Stegman, D.R., 2012. Origin of Columbia River flood basalt controlled by propagating rupture of the Farallon slab. Nature, 482(7385), p.386.

Mahood, G.A. and Benson, T.R., 2017. Using $40 \mathrm{Ar} / 39 \mathrm{Ar}$ ages of intercalated silicic tuffs to date flood basalts: Precise ages for Steens Basalt Member of the Columbia River Basalt Group. Earth and Planetary Science Letters, 459, pp.340-351.

McDougall, Ian, 1976, Geochemistry and origin of basalt of the Columbia River Group, Oregon and Washington: Geol. Soc. America Bull., v. 87, p. 777-792.

Moore, N.E., Grunder, A.L. and Bohrson, W.A., 2018. The three-stage petrochemical evolution of the Steens Basalt (southeast Oregon, USA) compared to large igneous provinces and layered mafic intrusions. Geosphere, 14(6), pp.2505-2532.

Nathan, S. and Fruchter, J.S., 1974. Geochemical and paleomagnetic stratigraphy of the Picture Gorge and Yakima basalts (Columbia River Group) in central Oregon. Geological Society of America Bulletin, 85(1), pp.63-76.

Osawa, M., and Goles, G. G., 1970, Trace element abundances in Columbia River basalts: Columbia River Basalt Symposium, 2d, Cheney, Washington, 1969, Proc.: Cheney, Eastern Washington State College Press, p. 173-175.

Peate, D.W., Barker, A.K., Riishuus, M.S., Andreason, R., 2008. Temporal variations in crustal assimilation of magma suites in the East Greenland flood basalt province: tracking the evolution of magmatic plumbing systems. Lithos 102, 179-197.

Reidel, S.P., Camp, V.E., Tolan, T.L., Kauffman, J.D., and Garwood, D.L., 2013, Tectonic evolution of the Columbia River flood basalt province, in Reidel, S.P., Camp, V.E., Ross, M.E., Wolff, J.A., Martin, B.S., Tolan, T.L., and Wells, R.E., 
eds., The Columbia River Flood Basalt Province: Geological Society of America Special Paper 497, p. 293-324, https:// doi .org /10 .1130/2013 .2497 (12).

Robinson, P.T., 1975. Reconnaissance geologic map of the John Day Formation in the southwestern part of the Blue Mountains and adjacent areas, north-central Oregon (No. 872).

Saunders, A.D., 2005. Large igneous provinces: origin and environmental consequences. Elements, 1(5), pp.259-263.

Self, S., Widdowson, M., Thordarson, T. and Jay, A.E., 2006, Volatile fluxes during flood basalt eruptions and potential effects on the global environment: A Deccan perspective. Earth and Planetary Science Letters, 248(1-2), pp.518-532.

Streck, M.J., Ferns, M.L. and McIntosh, W., 2015. Large, persistent rhyolitic magma reservoirs above Columbia River Basalt storage sites: The Dinner Creek Tuff Eruptive Center, eastern Oregon. Geosphere, 11(2), pp.226-235.

Streck, M.J., McIntosh, W., and Ferns, M.F. 2017, Columbia River Rhyolites: Agedistribution patterns and their implications for arrival, location, and dispersion of flood basalt magmas in the crust: Geological Society of America Abstracts with Programs, Session. 239, No. 7.

Swanson, D.A., Wright, T.L., Hooper, P.R. and Bentley, R.D., 1979. Revisions in stratigraphic nomenclature of the Columbia River Basalt Group (No. 1457-G).

Takahashi, E., Nakajima, K. \&Wright, T. L., 1998. Origin of the Columbia River basalts: Melting model of a heterogeneous plume head. Earth Planet. Sci. Lett. 162, 63-80.

Tolan, T. L., Reidel, S. P., Beeson, M. H., Anderson, J. L., Fecht, K. R., and Swanson, D. A., 1987, Revisions to the areal extent and volume of the Columbia River Basalt 
Group (CRBG): Geological Society of America Abstracts with Programs, v. 19, no. 6, p. 458.

Vander Meulen, D.B., Rytuba, J.J., Minor, S.A., Harwood, C.S., 1989, Preliminary geologic map of the Three Fingers Rock quadrangle, Malheur County, Oregon: U.S. Geological Survey Open-File Report 89-344, scale 1:24,000.

Wallace, R.E. and Calkins, J.A., 1956. Reconnaissance geologic map of the Izee and Logdell quadrangles, Oregon: US Geol. Survey Mineral Inv. Map MF82.

Waters, A., 1961, Stratigraphic and lithologic variations in the Columbia River Basalt: American Journal of Science, v. 259, p. 583-611, doi: 10.1475.ajs.259.8.583.

Watkins, N.D. and Baksi, A.K., 1974. Magnetostratigraphy and oroclinal folding of the Columbia River, Steens, and Owyhee basalts in Oregon, Washington, and Idaho. American Journal of Science, 274(2), pp.148-189.

Wilcox, R.E. and Fisher, R.V., 1966. Geologic map of the Monument quadrangle, Grant County, Oregon (No. 541).

Webb, B.M., Streck, M.J., McIntosh, W., and Ferns, M.L. and 2018. The Littlefield Rhyolite and associated mafic lavas: Bimodal volcanism of the Columbia River magmatic province, with constraints on age and storage sites of Grande Ronde Basalt magmas: Geosphere, v. 15 , no. 1.

Wolff, J.A., and Ramos, F.C., 2013, Source materials for the main phase of the Columbia River Basalt Group: Geochemical evidence and implications for magma storage and transport, in Reidel, S.P., Camp, V.E., Ross, M.E., Wolff, J.A., Martin, B.S., Tolan, T.L., and Wells, R.E., eds., The Columbia River Flood Basalt Province: Geological 
Society of America Special Paper, v. 497, p. 273-291, https:// doi .org /10 .1130 $/ 2013.2497(11)$.

Wolff, J.A., Ramos, F.C., Hart, G.L., Patterson, J.D., and Brandon, A.D., 2008, Columbia River flood basalts from a centralized crustal magmatic system: Nature Geoscience, v. 1, p. 177-180, https:// doi .org /10 .1038/ngeo124 .

Wright, T.L., Grolier, M.J. and Swanson, D.A., 1973. Chemical variation related to the stratigraphy of the Columbia River basalt. Geological Society of America Bulletin, 84(2), pp.371-386. 


\title{
CHAPTER 3
}

\section{MANTLE SOURCES AND GEOCHEMICAL EVOLUTION \\ OF THE PICTURE GORGE BASALT}

\begin{abstract}
The Columbia River Basalt Group (CRBG) is the youngest continental flood basalt province, presumably sourced from the deep-seated plume that currently resides underneath Yellowstone National Park. The earliest erupted basalts from this province aid in understanding and modeling plume impingement and subsequent evolution of basaltic volcanism. Using geochemical and isotopic data, this study explores potential mantle sources and magma evolution of the Picture Gorge Basalt (PGB).
\end{abstract}

Long known geochemical signatures of the PGB are typified by overall large-ionlithophile element (LILE) enrichment and exhibit relative depletion of high-field strength elements (HFSE) typical of other CRBG main-phase units. The PGB also contains ${ }^{87} \mathrm{Sr} /{ }^{86} \mathrm{Sr}$ values on the low end of the range displayed by other CRBG lavas. The relative strong enrichment of LILE and depletion of HFSE coupled with depleted isotopic signatures has suggested a metasomatized upper mantle as the most likely magmatic source for the PGB.

Early geochemical modeling of PGB utilized the composition of two high-MgO primitive dikes exposed in the northern portion of the Monument Dike swarm as parental melt. However, fractionation of these basalts cannot generate the compositional variability illustrated by basaltic lavas and dikes of the PGB. This study identifies a 
second potential parental PGB composition best represented by basaltic flows in the extended spatial distribution of PGB. This composition also better reflects the lowest stratigraphic flows identified in the previously mapped extent of PGB.

Age data reveals that PGB lavas erupted first and throughout eruptions of main phase CRBG units (Steens, Imnaha, Grande Ronde Basalt). Combining geochemical signals with these age data indicate cyclical patterns in the amounts of contributing mantle components. Eruption of PGB material occurred in two pulses, demonstrated by a $\sim 0.4$ Ma temporal gap in reported ages, 16.62 to 16.23 Ma. Coupling ages with observed geochemical signals, including strong relative elemental abundances of LILE, indicates increased influence of a more primitive, potentially plume-like source with time.

\section{INTRODUCTION}

The Columbia River Basalt Group (CRBG) of the Pacific Northwest, USA, is the world's youngest and least volumetric flood basalt (Fig. 3.1). The CRBG can be subdivided into four main-phase formations which include the Steens, Imnaha, Grande Ronde, and Picture Gorge Basalts (PGB). Of these formations, the PGB is the least volumetrically extensive and exhibits geochemical signatures which has suggested that it represents a separate magmatic system potentially resulting from lithospheric thinning and eruptive products represent a back-arc mantle melt (Wolff et al., 2008; Wolff and Ramos, 2013). Revisiting magma petrogenesis for the PGB, the earliest main-phase unit of the CRBG, provides insight into mantle components and their temporal and/or spatial boundaries. With more spatial, temporal, and geochemical similarities between PGB and other CRBG main-phase units like the Steens Basalt and coeval basalts of the Strawberry 
Volcanics, this study assesses the mantle sources and their respective contributions to the petrogenesis of the PGB.

In addition to mantle source components, an adjacent active subduction zone can further complicate the petrogenetic story of flood basalt emplacement. The Cascade volcanic arc is located $\sim 400 \mathrm{kms}$ west of the central portion of the CRBG (Fig. 3.1), and volcanism associated with the Cascade subduction zone initiated $\sim 54 \mathrm{Ma}$. Additional magmatism post-subduction can result from lithospheric thickening, thermal rebound, or delamination of lithospheric mantle. Although the arc is still active, its central eruptive axis has spatially shifted over time (Wells, 1990). These volcano-tectonic processes can result in basaltic volcanism whose eruptive products may share geochemical and isotopic characteristics with subduction-related magmatism. These magmas tend to be more alkaline and more isolated in distribution and timing, and are derived by continued melting of the metasomatized roots of former arc magmatic systems (Richards, 2009).

\section{GEOLOGIC SETTING}

\section{Mantle Components for the CRBG}

Through the decades of research on the CRBG flood lavas, numerous origins and source materials have been proposed by many workers to contribute to the geochemical diversity exhibited by the basalts (Carlson et al., 1981; Carlson, 1984; Brandon et al., 1993; Geist and Richards, 1993; Hales et al., 2005; Camp and Hanan, 2008; Wolff et al., 2008; Camp, 2019; Moore et al., 2020). These source components include a mantle plume, subcontinental lithospheric mantle that is variably metasomatized by prior subduction zone processes, and various crustal lithologies within the North American 
plate. Many workers agree that a mantle plume is ultimately responsible for the CRBG and the Snake River Plain-Yellowstone hotspot track to the east, although different nonplume models of plume-lithosphere interaction have been proposed. Examples of some these models invoke a northward opening tear in the descending slab (Liu and Stegman, 2012), peeling-off of the Farallon plate (Camp and Hanan, 2008), and a similar modeling of peeling-off of the Farallon plate with the added component of lithospheric foundering at the root of the Wallowa Mountains in northeastern Oregon (Hales et al., 2005).

\section{Geochemical Relationships Between Main-Phase CRBG Formations}

End-member compositions within main-phase formations of the CRBG reflects contribution of multiple mantle source components, as interpreted by trace element and isotopic data (Carlson et al., 1981; Carlson, 1984; Hooper and Hawkesworth, 1993; Brandon et al., 1993; Wolff et al., 2008; and Camp and Hanan, 2008). In isotopic space the Grande Ronde Basalts and Imnaha Basalts define their own trend while the PGB and Steens Basalt share other distinct geochemical and isotopic traits (Carlson, 1984; Hooper and Hawkesworth, 1993; Wolff et al., 2008; Wolff \& Ramos, 2013). Partial melting processes within source region likely also contributes to some of the observed similarities (Hooper and Hawkesworth, 1993). The Grande Ronde Basalts form a trend toward Imnaha Basalts in isotopic space, and could represent crustally contaminated Imnaha Basalts (Wolff et al., 2008). The 'end-member' identified within Imnaha Basalts was originally interpreted as re-enriched mantle, possibly the result of added sediment to a depleted mantle component (Carlson, 1984). This mantle source was defined as 'C1' by Carlson (1984) and later named the 'Imnaha Component' which is most similar to Ocean Island Basalt (OIB) and thought to best represent a plume source within CRBG lavas 
(Wolff et al., 2008). Significant crustal contamination of Imnaha Basalt could produce Grande Ronde Basalts if the assimilating material was cratonic crust and not accreted terrane rocks (Wolff et al., 2008).

The Steens Basalt is modeled as the result of a depleted mantle component ( $\mathrm{C} 2$ of Carlson, 1984) mixing with the Imnaha component, or plume source (Wolff et al., 2008). Within lavas of the Steens Basalt, the proportion of depleted mantle decreases with time, moving stratigraphically upwards through lower to upper Steens Basalt. Lower Steens lavas reflect a higher contribution of a depleted mantle component than do upper Steens lavas, suggesting the proportion of the Imnaha component in Steens Basalt increases with time. This is evidenced in isotopic space by ${ }^{87} \mathrm{Sr} /{ }^{86} \mathrm{Sr}$ versus ${ }^{206} \mathrm{~Pb} /{ }^{204} \mathrm{~Pb}$, where the upper Steens Basalt resides closer to the defined Imnaha Component than lower Steens Basalt (Wolff et al., 2008; Wolff and Ramos, 2013). This observation also applies to the lower Imnaha Basalts, the depleted mantle component is most prevalent in the earliest erupted Imnaha lavas (Swanson et al., 1979; Wolff \& Ramos, 2013).

The PGB shares the most geochemical characteristics with the Steens Basalt and the American Bar subtype of the Imnaha Basalt (Fig. 3.2). Similar to the Steens Basalt, PGB magmas are interpreted to be represent a depleted mantle source, but significantly influenced by prior subduction (Hooper and Hawkesworth, 1993). The observed enrichment of LILE relative to HFSE is one of the more characteristic geochemical signatures in PGB lavas and dikes, especially on a mantle-normalized trace element diagram and evidence for a fluid-fluxed mantle component (Fig. 3.3)(McDougall, 1976; Carlson et al., 1981; Carlson, 1984; Bailey, 1989; Brandon et al.,1993; Hooper and Hawkesworth, 1995; Wolff et al., 2008; Wolff \& Ramos, 2013). In context of the entire 
flood basalt province, the PGB reflects a subduction overprinted back-arc mantle less influenced by plume magmatism compared to the rest of the CRBG (Wolff et al., 2008).

\section{Petrogenetic Significance of Picture Gorge Basalt Stratigraphy}

The PGB is best exemplified by the type locality at Picture Gorge, where 18 total basaltic flows are exposed in a continuous stratigraphic section. These lavas erupted from north-northwest trending dikes of the Monument Dike swarm (Swanson et al. 1979; Brandon et al., 1993; Bailey, 1989), and can be subdivided into three subunits (Fig. 3.4), differentiated by plagioclase modal abundance, major element concentrations specifically $\mathrm{TiO}_{2}$ and $\mathrm{MgO}$ (wt. \%), and magnetic orientation (Osawa and Goles 1970; Nathan and Fruchter, 1974; McDougall 1976; Swanson et al. 1979; Watkins and Baksi, 1974; Goles 1986; Bailey 1989). The three PGB subunits include the Twickenham, Monument Mountain, and Dayville Basalts, which are further subdivided into 17 members and a distinct composition classified as high-MgO dikes (Bailey, 1989).

The high-MgO dikes, identified as potential parental material, are enriched in $\mathrm{Ba}$, $\mathrm{K}$ and $\mathrm{Rb}$ relative to $\mathrm{N}-\mathrm{MORB}$, suggesting some crustal contamination or slab-derived fluids fluxing the source. This enrichment in large ion lithophile elements (LILE) is also observed in the Twickenham Basalt subunit and in the Monument Mountain Basalt subunit but to a lesser degree (Bailey, 1989). Extrusion of Monument Mountain lavas which was followed by decrease in eruptive activity, interpreted from spatially limited and compositionally diverse lava flows within the youngest PGB subunit, the Dayville Basalt. Overall, the Twickenham and Monument Mountain Basalts exhibit minor variation which cannot be the result of closed-system fractionation (Bailey, 1989), and the younger Dayville Basalt forms its own evolutionary trend (Fig. 3.4). 


\section{METHODS}

\section{Major and Trace Element Concentration}

Major and trace element data was acquired at the Peter Hooper GeoAnalytical Lab at Washington State University (WSU) using a Thermo-ARL Advant'XP automated X-ray fluorescence spectrometer (XRF), and an Agilent 7700 inductively coupled plasma mass spectrometer (ICP-MS). For sample preparation, basaltic samples were crushed into chips using the Braun Chipmunk at WSU. Then, weathered surfaces were removed from the chips so that alteration wouldn't affect the results. Rock chips were further crushed into a powder in a tungsten carbide swing mill. The powder was then combined with dilithium tetraborate $\left(\mathrm{Li}_{2} \mathrm{~B}_{4} \mathrm{O}_{7}\right)$ in a ratio of $2: 1$, dilithium tetraborate to sample. The sample was fused into a bead in an oven at a temperature of $1000^{\circ} \mathrm{C}$. The beads were regrinded into powder, and one gram of powder was separated in order to make the ICPMS bead. Two beads per sample were then made, again at $1000^{\circ} \mathrm{C}$, one for $\mathrm{XRF}$ and one for ICP-MS analysis. The XRF bead was analyzed in the XRF instrument, and the ICPMS bead was dissolved for final analysis. These data provided whole-rock major and trace elemental data to confirm samples were PGB.

\section{Radiogenic Isotope Analyses}

Sample preparation and analysis for $\mathrm{Sr}, \mathrm{Nd}, \mathrm{Pb}$, and $\mathrm{Hf}$ were performed at the Carnegie Institution for Science Department of Terrestrial Magnetism (DTM) in Washington D.C. Sample preparation and analyses were conducted in 2017 and 2018 during two separate laboratory visits. During both visits, over 10 grams of fresh rock chips from each sample were powdered in an agate ceramic bowl to avoid contamination 
of metals (i.e. Ta from WC grinding bowls). Once the sample was powdered, approximately $50 \mathrm{mg}$ was weighed and dissolved in $\sim 2 \mathrm{ml}$ of concentrated $\mathrm{HNO}_{3}$ and 4 $\mathrm{ml}$ concentrated HF. The mixture in a Savillex Teflon vial was capped and heated on a $90^{\circ} \mathrm{C}$ hotplate for $\sim 12-18$ hours. Samples were heated longer (i.e. 18 hours) during the 2017 sample preparation as the result of a laboratory closure. Each sample solution was then evaporated, redissolved twice in $1 \mathrm{ml}$ of concentrated $\mathrm{HNO}_{3}$, and dissolved again in $4 \mathrm{ml}$ of $4 \mathrm{M} \mathrm{HCl}$. Finally, samples were evaporated, dried two more times with $0.5 \mathrm{ml}$ $0.5 \mathrm{~N} \mathrm{HBr}$, and redissolved in $3 \mathrm{ml}$ of $0.5 \mathrm{~N} \mathrm{HBr}$. Following these acid digestions, elements of interest ( $\mathrm{Sr}, \mathrm{Nd}, \mathrm{Hf}$, and $\mathrm{Pb}$ ) were separated and purified via column chromatography following the procedures described below.

Lead was separated first by loading the samples (in $3 \mathrm{~mL} 0.5 \mathrm{~N} \mathrm{HBr}$ ) on $0.04 \mathrm{~mL}$ Teflon columns with AG1-X8 100-200 mesh anion exchange resin following the methodology of Carlson et al. (2006). Following elution of the majority of the elements using $0.5 \mathrm{~N} \mathrm{HBr}$, the $\mathrm{Pb}$ fraction was collected in $1.5 \mathrm{ml} \mathrm{HNO}_{3}$, dried on a hotplate, and after adding $1 \mathrm{ml} 0.5 \mathrm{~N} \mathrm{HBr}$ loaded onto the columns a second time for purification. The final $\mathrm{Pb}$ fraction was collected in $1.5 \mathrm{ml} 0.5 \mathrm{~N} \mathrm{HNO}_{3}$. The remaining sample in $0.5 \mathrm{~N} \mathrm{HBr}$ was then dried, oxidized with $0.5 \mathrm{ml}$ of concentrated $\mathrm{HNO}_{3}$, evaporated again, redissolved in $5 \mathrm{ml}$ of $0.1 \mathrm{~N} \mathrm{HF}-1 \mathrm{~N} \mathrm{HCl}$, and heated for approximately one hour at $80^{\circ} \mathrm{C}$. Next, samples were centrifuged to remove any precipitates, and loaded on AG 50Wx8 resin (200-400 mesh), $20 \mathrm{~cm}$ height x 6mm ID.

The high-field strength elements, including hafnium were separated next by collecting the initial solution and an additional $5 \mathrm{ml}$ of $0.1 \mathrm{~N} \mathrm{HF}-1 \mathrm{~N} \mathrm{HCl}$ following a procedure modified from Patchett and Tatsumoto (1980). The eluant was then switched 
to $2.5 \mathrm{~N} \mathrm{HCl}$ with $30 \mathrm{ml}$ eluted until the $\mathrm{Sr}$ cut was collected in an additional $14 \mathrm{ml}$ of 2.5N HCl. Switching to $4 \mathrm{~N} \mathrm{HCl}$, the light REE were collected in $16 \mathrm{ml}$ after eluting and discarding $12 \mathrm{ml}$.

Hafnium was purified on 0.6 x $10 \mathrm{~cm}$ columns using Eichrom LN 100-150 $\mu \mathrm{m}$ resin. The sample was loaded in $5 \mathrm{ml}$ of $2.5 \mathrm{~N} \mathrm{HCl}$ and rinsed with $10 \mathrm{ml} 2.5 \mathrm{~N} \mathrm{HCl}, 10$ $\mathrm{ml} 6 \mathrm{~N} \mathrm{HCl}, 4 \mathrm{ml}$ of Milli-Q (MQ) water, $60 \mathrm{ml}$ of $0.09 \mathrm{~N}$ citric acid- $0.45 \mathrm{~N} \mathrm{HNO}_{3}-1 \mathrm{wt} . \%$ $\mathrm{H}_{2} \mathrm{O}_{2}, 5 \mathrm{ml}$ of $0.09 \mathrm{~N}$ Citric acid- $0.45 \mathrm{~N} \mathrm{HNO}_{3}$, and $20 \mathrm{ml}$ of $6 \mathrm{~N} \mathrm{HCL}-0.06 \mathrm{~N} \mathrm{HF}$. The final Hf sample was collected in $8 \mathrm{ml}$ of $6 \mathrm{~N} \mathrm{HCl}-0.4 \mathrm{~N} \mathrm{HF}$. Strontium was purified on $0.25 \mathrm{~mL}$ Teflon columns with Eichrom Sr resin. The purified Sr sample was collected in $2 \mathrm{~mL}$ of $0.05 \mathrm{M} \mathrm{HNO}_{3}$. Neodymium was separated from the other REE following the procedure of Garcon et al. (2018) on columns with 10-50 $\mu \mathrm{m}$ LN spec resin and collected in $9 \mathrm{~mL}$ of $0.173 \mathrm{~N} \mathrm{HCl}$.

Isotopic compositions for $\mathrm{Sr}$ and $\mathrm{Nd}$ were measured via thermal ionization mass spectrometry (TIMS) on the Thermo-Fisher Triton. Sr was run on single Re filaments loaded in a $\mathrm{Ta}_{2} \mathrm{O}_{5}$ powder in dilute $\mathrm{H}_{3} \mathrm{PO}_{4}$-HF. Each ${ }^{87} \mathrm{Sr} /{ }^{86} \mathrm{Sr}$ ratio reported in Table 3.3 is the average of 279-290 ratios obtained using 8 second integrations with a signal size from 5-20 x $10^{-11}$ A. of ${ }^{88} \mathrm{Sr}$. Mass fractionation was corrected to ${ }^{86} \mathrm{Sr} /{ }^{88} \mathrm{Sr}=0.1194 \mathrm{using}$ exponential mass dependency and reported relative to a value of 0.71025 for the NBS987 Sr standard. The Sr standard NBS987 was measured multiple times during the 2017 and 2018 analytical sessions and averaged $0.710240 \pm 0.0000027(n=3)$ in 2017 and $0.710249 \pm 0.000003(\mathrm{n}=3)$ in 2018 , where uncertainty is $2 \sigma$. For all but one sample, the uncertainty on ${ }^{87} \mathrm{Sr} /{ }^{86} \mathrm{Sr}$ was 0.000003 . Uncertainties for all samples are reported in Appendix F. 
Each ${ }^{143} \mathrm{Nd} /{ }^{144} \mathrm{Nd}$ ratio reported in Table 3.3 is the average of 199-203 ratios (in 2017) or 233-279 (in 2018) obtained using 8 second integrations with a signal size from $1-3 \times 10^{-11} \mathrm{~A}$ of ${ }^{144} \mathrm{Nd}$. Mass fractionation was corrected using exponential mass dependency and ${ }^{146} \mathrm{Nd} /{ }^{144} \mathrm{Nd}=0.7219$. The $\mathrm{Nd}$ standard JNdi was measured multiple times during the 2017 analytical sessions and averaged $0.5121117 \pm 0.0000023(\mathrm{n}=3)$, where uncertainty is $2 \sigma$. During the 2018 analytical sessions the data for JNdi averaged $0.5120940 \pm 0.0000017(n=3)$, where uncertainty is $2 \sigma$. Data for the samples are adjusted to a JNdi value of 0.512115 (Tanaka et al. 2000) based on the average value determined for JNdi during the separate analytical sessions.

Isotopic compositions for $\mathrm{Pb}$ and $\mathrm{Hf}$ were measured on the $\mathrm{Nu} \mathrm{HR}$ multicollector ICP-MS and Nu Plasma II multicollector ICP-MS. Each Pb ratio reported in Table 3.3 is the average of 41-50 ratios. Samples that yielded ${ }^{208} \mathrm{~Pb}$ signals below $100 \mathrm{mv}$ were not reported. Mass fractionation during the 2017 analyses was corrected to ${ }^{205} \mathrm{Tl} /{ }^{203} \mathrm{Tl}=$ 2.417, and then adjusted for the difference between the NBS981 Pb standards measured every 4 samples and the reported value for the standard (Todt et al. 1996). Mass fractionation during the 2018 analyses was corrected to ${ }^{205} \mathrm{Tl} /{ }^{203} \mathrm{Tl}=2.410$, and then adjusted for the difference between the NBS981 Pb standards measured every 4 samples and the reported value for the standard (Todt et al. 1996). Average values for NBS981 obtained during 2017 analytical sessions for $\mathrm{n}=7$ measurements were ${ }^{208} \mathrm{~Pb} /{ }^{204} \mathrm{~Pb}=$ $36.714 \pm 0.006,{ }^{207} \mathrm{~Pb} /{ }^{204} \mathrm{~Pb}=15.497 \pm 0.003$, and ${ }^{206} \mathrm{~Pb} /{ }^{204} \mathrm{~Pb}=16.941 \pm 0.003$ where uncertainty is $2 \sigma$. Average values for NBS981 obtained during 2018 analytical sessions for $\mathrm{n}=6$ measurements were ${ }^{208} \mathrm{~Pb} /{ }^{204} \mathrm{~Pb}=36.703 \pm 0.028,{ }^{207} \mathrm{~Pb} /{ }^{204} \mathrm{~Pb}=15.495 \pm 0.011$, 
and ${ }^{206} \mathrm{~Pb} /{ }^{204} \mathrm{~Pb}=16.938 \pm 0.012$ where uncertainty is $2 \sigma$. Uncertainties for all samples are provided in Appendix F.

Hafnium isotopic compositions were measured by introducing samples into the plasma in $0.08 \mathrm{~N} \mathrm{HNO} 3-0.06 \mathrm{~N}$ HF via a Teflon nebulizer. Each ratio reported in Table 3.3 is the average of 52-80 ratios, and signal size of ${ }^{178} \mathrm{Hf}$ ranged from $3-8 \times 10^{-11} \mathrm{~A}$. Mass fractionation was corrected to ${ }^{179} \mathrm{Hf} /{ }^{177} \mathrm{Hf}=0.7325$. The average of JMC475 obtained during the 2017 analytical sessions for $\mathrm{n}=3$ measurements was ${ }^{176} \mathrm{Hf} /{ }^{177} \mathrm{Hf}=$ $0.282148 \pm 0.000002(2 \sigma)$. The average of JMC475 obtained during the 2018 analytical sessions for $\mathrm{n}=13$ measurements was ${ }^{176} \mathrm{Hf} /{ }^{177} \mathrm{Hf}=0.282144 \pm 0.000002(2 \sigma)$. Reported ${ }^{176} \mathrm{Hf} /{ }^{177} \mathrm{Hf}$ ratios were adjusted based on the average value determined for JNdi during the separate analytical sessions corrected to a JMC475 value of 0.282160 . Values for eHf and eNd are calculated using the average chondrite parameters from Bouvier et al. (2008) of ${ }^{176} \mathrm{Hf} /{ }^{177} \mathrm{Hf}=0.282785$ and ${ }^{143} \mathrm{Nd} /{ }^{144} \mathrm{Nd}=0.512630$.

\section{Oxygen Isotope Analyses}

In order to better quantify contamination, $\delta^{18} \mathrm{O}$ values are revisited with modern techniques applied to both plagioclase mineral separates and basaltic groundmass that was exposed to multiple acid leaching's to remove excess alteration. Basaltic groundmass and plagioclase separates were analyzed from 16 basaltic flows. The samples were crushed, sieved to grain sizes between $180-150$ or $250 \mathrm{um}$, magnetically separated via Franz, and leached in acid. Samples were prepared at Oregon State University following procedures for ArAr dating (refer to Chapter 1 ArAr methods), and remaining groundmass and mineral separates were used for oxygen isotope analysis. Oxygen isotopes were then measured at the University of Oregon via an integrated $\mathrm{CO}_{2}$ laser 
fluorination MAT 253 isotope ratio mass spectrometer (IRMS) system (Bindeman, 2008; Loewen and Bindeman, 2015). The range of material analyzed from each sample was 1.2 to $1.6 \mathrm{mg}$. During the analytical session, the Gore Mountain Garnet standard (UOG, accepted $\delta^{18} \mathrm{O}=6.52 \%$ ) was measured multiple times $(\mathrm{n}=7)$ to correct for instrumental drift (Loewen and Bindeman, 2015). Analytical precision of UOG analyses from the session was $0.06 \%(2 \sigma)$ and reported in Appendix G.

\section{MELTS Calculations}

MELTS calculations were conducted using version rhyoliteMELTS v1.2x with two distinct primitive compositions identified as PGB (Bailey, 1989; Wolff et al., 2008; Cahoon et al., 2020). Compositions were modeled at 6 different pressures $(2,3,4,7,8$, and $9 \mathrm{~kb}$ ) with 0.1 and $0.5 \mathrm{wt} . \%$ water. For each experiment, pressure stayed constant and temperature decreased 100 degrees $\mathrm{C}$ below the wet liquidus temperature as calculated by MELTS. Utilized partition coefficients are compiled in Table 3.1 and results of each individual model are summarized in Appendix H.

\section{RESULTS}

\section{PGB Composition}

\section{Major and Trace Element Compositions}

Newly identified basaltic lavas and dikes of PGB composition extend across a wide swath of eastern Oregon. Samples of these and of PGB from the original distribution have relatively primitive to evolved ( $\mathrm{MgO} \sim 4-9$ wt.\%) compositions with flat to slightly negatively sloping patterns on mantle-normalized incompatible trace element diagrams, but with troughs and spikes typically associated with volcanic arc related lavas 
of the Pacific Northwest (Fig. 3.3). Samples of PGB composition exhibit depletions in many incompatible elements (i.e. $\mathrm{La}, \mathrm{Nb}, \mathrm{Rb}, \mathrm{Hf}, \mathrm{Th}$ ) relative to other $\mathrm{CRBG}$ units, overall elevated large-ion-lithophile element (LILE) to high-field-strength element (HFSE) ratios, and less of a HREE depletion on a mantle-normalized trace element diagram (Figs. 3.2, 3.3).

To assess the geochemical variation of the PGB, major and trace elements were plotted against $\mathrm{Mg} \#(\mathrm{Mg} \#=(\mathrm{Mg} /(\mathrm{Mg}+\mathrm{Fe}) * 100))$, one of the most useful geochemical parameter used to gauge fractionation and primitive composition of basalts (Appendix E). Observed trends in both major and trace element space define broad bands on most geochemical plots. Major element concentrations exhibit larger variability between $\mathrm{Mg} \#$ 65-45 (i.e. $\mathrm{Al}_{2} \mathrm{O}_{3}, \mathrm{MnO}, \mathrm{P}_{2} \mathrm{O}_{5}$, and $\mathrm{FeO}^{*}$ ), and both $\mathrm{FeO}^{*}$ and $\mathrm{MgO}$ exhibit a slight inflection at $\mathrm{Mg} \#$ of 45. Many incompatible trace elements increase by a factor of 2 (i.e. $\mathrm{Hf}, \mathrm{Nb}, \mathrm{Zr}$, and more), and minimal relative variability is observed with $\mathrm{Yb}, \mathrm{Y}$, and $\mathrm{Dy}$ at a given $\mathrm{Mg} \#$ value (i.e. tight correlation with evolution to lower $\mathrm{Mg \# )}$.

Using these geochemical plots, two envelopes encompassing the geochemical spread of samples of all previous and additional PGB samples can be described. These envelopes are anchored on the high $\mathrm{Mg \#}$ side and trend roughly subparallel to more evolved compositions particular in incompatibly behaving elements. The composition at the high $\mathrm{Mg} \#$ have a $\mathrm{Mg} \#>$ 59.5. This could represent potential parental sources (see below, Appendix E). The high Mg\# PGB samples at the end of the two envelops are best represented by samples of the high- $\mathrm{MgO}$ dikes and lava flows exposed along Rattlesnake Road in the southeastern region of the PGB extended distribution (Fig. 3.1, Table 3.2). Although other samples could have been chosen, samples of Rattlesnake Road were 
selected because there are four analyses from this location and their classification as PGB has been further confirmed by Oregon Department of Geology and Mineral Industries (DOGAMI)(R. A. Houston et al., 2017). Overall, these high Mg\# samples reflect two groups of primitive compositions observed within the $\mathrm{PGB}$, referred to as the high- $\mathrm{MgO}$ dike (HMD) and the Rattlesnake Road (RR) groups (Table 3.2).

\section{Radiogenic and Oxygen Isotope Compositions}

Isotopically, PBG lavas have the lowest ${ }^{87} \mathrm{Sr} /{ }^{86} \mathrm{Sr}$ ratios of all main-phase CRBG units; and the most primitive PGB dikes contain the lowest ${ }^{87} \mathrm{Sr} /{ }^{86} \mathrm{Sr}$ ratios observed within PGB (Brandon and Goles, 1995). New radiogenic isotope data are reported for 16 sampled basaltic lavas and dikes of the PGB. Samples from within and outside of the previously mapped extent have ${ }^{87} \mathrm{Sr} /{ }^{86} \mathrm{Sr}$ ratios from 0.70341 to 0.70376 and ${ }^{143} \mathrm{Nd} /{ }^{144} \mathrm{Nd}$ ratios from 0.51299 to 0.51289 (Fig. 3.5). The only exception are samples of PGB lavas from Pole Creek in the Malheur Gorge. These samples contain higher ${ }^{87} \mathrm{Sr} /{ }^{86} \mathrm{Sr}$ ratios $>0.7039$ and lower ${ }^{143} \mathrm{Nd} /{ }^{144} \mathrm{Nd}$ ratios $<0.5129$ than the rest of the PGB, but resemble the PGB in major and trace element concentrations (Fig. 2.10).

Combining isotopic data with trace element data, samples of the identified primitive groups (HMD \& RR) are evaluated to see if they share isotopic similarities. The HMD group is best characterized by three samples in trace element and isotopic space (sample ID: MMB-D69A, MMB-D69B, \& MMB-D70A. The RR group is characterized by three samples (CAH16-241A, DM255B, \& CAH15-007). Because RR group sample CAH16-241A does not have isotopic data, it is substituted with a similar basaltic lava along Rattlesnake Road (CAH16-242A) that does (Fig. 3.6D-F). Considering trace element and radiogenic isotope data together, samples of the RR group exhibit lower 
$\mathrm{Y} / \mathrm{P}_{2} \mathrm{O}_{5}$ and higher LREE concentrations at lower ${ }^{143} \mathrm{Nd} /{ }^{144} \mathrm{Nd}$ values (Fig. 3.6B).

Samples of each group show variable ${ }^{87} \mathrm{Sr} /{ }^{86} \mathrm{Sr}$ ratios relative to other isotope ratios (i.e.

${ }^{143} \mathrm{Nd} /{ }^{144} \mathrm{Nd}$ or ${ }^{206} \mathrm{~Pb} /{ }^{204} \mathrm{~Pb}$, Fig.3.7 C, D). Within the RR group, ${ }^{87} \mathrm{Sr} /{ }^{86} \mathrm{Sr}$ values are >

0.7035 and ${ }^{143} \mathrm{Nd} /{ }^{144} \mathrm{Nd}$ values $<0.51293$. In the HMD group ${ }^{87} \mathrm{Sr} /{ }^{86} \mathrm{Sr}$ values are $<$

0.7034 and ${ }^{143} \mathrm{Nd} /{ }^{144} \mathrm{Nd}$ values $>0.51298$ (Fig. 3.7).

Oxygen isotope data for the PGB yield $\delta^{18} \mathrm{O}$ values ranging from 5.28 to $6.68 \%$ in groundmass, and 5.32 to $5.92 \%$ in plagioclase, from samples which yield older and younger ages (17.23-16.06 Ma, Table 3.3). When compared with previous work, these data demonstrate a larger range of values from groundmass and a similar overall trend of increasing $\delta^{18} \mathrm{O}$ values for younger samples (Fig. 3.8). This trend is observed with the earlier ${ }^{87} \mathrm{Sr} /{ }^{86} \mathrm{Sr}$ isotopic data, where PGB flows lower in the stratigraphy had lower ratios and higher stratigraphic flows slightly higher ratios. Comparing ${ }^{87} \mathrm{Sr} /{ }^{86} \mathrm{Sr}$ data with $\delta^{18} \mathrm{O}$ values collected as part of this study, there is a clear linear correlation $\left(\mathrm{R}^{2}=0.92\right)$ (Fig. 3.5D). Interestingly, previously reported PGB data reflects lower ${ }^{87} \mathrm{Sr} /{ }^{86} \mathrm{Sr}$ values with similar $\delta^{18} \mathrm{O}$.

\section{Distinguishing Basaltic Lavas and Dikes of the PGB}

Samples of PGB are distinguished from other main-phase CRBG formations (Grande Ronde, Imnaha, and Steens Basalt) using a number of specific geochemical parameters. Relative to the Grande Ronde Basalt, the PGB is easy to differentiate as it contains lower concentrations of $\mathrm{SiO}_{2}($ mostly $<53$ wt. \%) and generally lower incompatible trace elements contents, for example, La, Y, and Hf (Fig. 3.2). Compared to the Imnaha Basalt, which can be subdivided into two subtypes, Rock Creek $\left(<51 \% \mathrm{SiO}_{2}\right)$ and American $\mathrm{Bar}\left(>51 \%\right.$, cf. Hooper, 1974), the $\mathrm{PGB}$ exhibits a comparable $\mathrm{SiO}_{2}$ range 
(48.5 to $53 \mathrm{wt} . \%$ ) but with lower concentrations of various incompatible elements (i.e. Th, Hf, La) at a similar $\mathrm{SiO}_{2}$ content (Fig. 3.2).

More complicated is distinguishing PGB near the northern extent of Steens Basalt, as both PGB and Steens Basalt are coarsely plagioclase-phyric and contain a similar $\mathrm{SiO}_{2}$ range. However, they are easily differentiated using $\mathrm{Zr} / \mathrm{Y}$ ratios. At low $\mathrm{SiO}_{2}$ the PGB contains $\mathrm{Zr} / \mathrm{Y}<4$, and at high $\mathrm{SiO}_{2}$ the $\mathrm{PGB}$ contains $\mathrm{Zr} / \mathrm{Y}<4.5$, while samples of Steens Basalt indicate ratios $>4$ and $>4.5$, respectively (Fig. 3.2). The PGB also contains lower Hf, Th, and La concentrations, and more evolved upper Steens Basalt tend to be more alkalic which deviate from more evolved PGB samples (Fig. 3.2D, E).

\section{Fractionation Models to Account for PGB Geochemical Variability}

The two identified primitive basaltic compositions are observed in samples from both the original and extended PGB distribution and marks the starting point of both envelopes (Appendix E). Samples of the RR group contain geochemical signatures similar to the earliest PGB subunit the Twickenham Basalt (Fig. 3.8B), while samples of the HMD group are from high-MgO dikes that are independent of the three PGB subunits (Fruchter and Baldwin, 1975; Bailey, 1989). Comparing the three PGB subunits, it is clear there is one evolutionary trend for the Twickenham and Monument Mountain Basalts, and another for the Dayville Basalts which are anchored by the high-MgO dikes (Figs. 3.4, 3. 8). The distinction between the geochemical evolution of the Twickenham Basalt (and Monument Mountain) versus the high-MgO dikes (and Dayville Basalts) is best exemplified by select trace and major elements. This is particularly well reflected with different $\mathrm{P}_{2} \mathrm{O}_{5}$ (wt.\%) for similar $\mathrm{Y}$ (ppm) concentrations and therefore useful to consider as a ratio (i.e. $\mathrm{Y} / \mathrm{P}_{2} \mathrm{O}_{5}$ ), especially as $\mathrm{Y}$ has a close correlation with magmatic 
evolution (Figs. 3.6, 3.8). Geochemical variations within the original PGB stratigraphy have previously been attributed to magmatic eruptive cycles of variable volumes (Bailey, 1989).

Identified primitive groups (HMD \& RR) are used as parent compositions for fractionation models in MELTS. These compositions include a sample from the highMgO dikes (HMD sample ID: MMB D70A, Wolff et al., 2008) and a sample from a lava flow located along Rattlesnake Road (RR sample ID: CAH16-241A, this study) (Fig. 3.1, Table 3.2). Using these two PGB compositions, a total of 24 MELTS models were conducted under variable crustal pressures $(2-4 \mathrm{~kb} \& 7-9 \mathrm{~kb})$ and water content $(0.1$ and 0.5 wt. $\% \mathrm{H}_{2} \mathrm{O}$ ) (Appendix H). During each model, pressure is held constant and temperature is lowered 100 degrees below the calculated liquidus. Model outputs include crystallizing mineral phases and their modal abundance, major element concentrations, and select trace element concentrations calculated using bulk partition coefficients (Di) (Appendix H). Select trace elements include $\mathrm{Y}, \mathrm{La}, \mathrm{Ba}, \mathrm{Th}, \mathrm{Sc}$, and $\mathrm{Cr}$ where the behavior of each element in the magma is dictated by a bulk partition (or distribution) coefficient (Di). This bulk partition coefficient is defined as:

$D_{i}=\sum \phi X \phi D i \phi$

$\mathrm{X}$ is the weight fraction of phase $\phi$ and

Di is the partition coefficient for component $i$ in phase $\phi$ 
Utilized partition coefficients are summarized in Table 3.1 and their internal consistency illustrated using Onuma diagrams (Onuma et al.,1968) (Appendix J). Results of each MELTS model is summarized in Appendix H.

Modelling results of the HMD composition indicate the following. Model fractionation varied between $\sim 75-82 \%$ at all pressures with $0.1 \mathrm{wt} . \% \mathrm{H}_{2} \mathrm{O}$, and varied between $\sim 54-67 \%$ when the starting composition contained $0.5 \mathrm{wt} . \% \mathrm{H}_{2} \mathrm{O}$. For models conducted under low pressures (2-4kb) plagioclase and spinel are the first crystallizing phases followed by olivine and clinopyroxene. At higher pressures (7-9kb) clinopyroxene and spinel crystallize first, followed by plagioclase. Olivine is only a crystallizing phase under low pressure conditions (i.e. $2-4 \mathrm{~kb}$ ), and spinel is a minor phase $(<1 \%)$ under low pressure conditions, and ranges from 1-2.3\% with higher pressure. A high and low-Ca clinopyroxene crystallize during each model, except at 2 and $9 \mathrm{~kb}$ at $0.5 \mathrm{wt} . \% \mathrm{H}_{2} \mathrm{O}$. he high Ca clinopyroxene ( $\sim 17$ wt.\%) crystallizes just a bit earlier than the low $\mathrm{Ca}$ clinopyroxene ( 4-7 wt.\%). Considering both clinopyroxene populations, the modal abundance of clinopyroxene is similar ( 48-49) for models run at higher pressures (7$9 \mathrm{~kb})$. Model results also indicate increases in the modal abundance of the earlier formed, high $\mathrm{Ca}$ clinopyroxene with increasing pressure, where the later formed and lower $\mathrm{Ca}$ clinopyroxene decreases with increasing pressure. At low pressures (2-4kb), the modal abundance of both clinopyroxene populations is much more variable and increases with pressure (i.e. $2-3 \mathrm{~kb}$ and $3-4 \mathrm{~kb}$ ).

Modelling results using the RR composition indicate maximum fractionation degrees between $74-80 \%$ at lower pressures (2-4 kb), and 52-62\% at higher pressures (7$9 \mathrm{~kb}$ ) with 0.1 wt. $\% \mathrm{H}_{2} \mathrm{O}$. When the melt contained 0.5 wt. $\% \mathrm{H}_{2} \mathrm{O}$, maximum 
fractionation degrees varied between $58-63 \%$ at lower pressures $(2-4 \mathrm{~kb})$ and $35-45 \%$ at higher pressures (7-9 kb) (Appendix H). Mineral phases typically crystallized in the following sequence, orthopyroxene, followed by spinel, plagioclase, and clinopyroxene. Similar to model results using the HMD, fractionation of the RR composition predicts two populations of clinopyroxene, a high (>15 wt.\%) and a low ( $<10 \mathrm{wt} . \%) \mathrm{Ca}$ clinopyroxene. Both the high and low Ca populations of clinopyroxene crystallize with every model. For all modeled conditions, the modal abundance of clinopyroxene (both high and low $\mathrm{Ca}$ ) remains similar and plagioclase decreases with increasing pressure, and only under low pressure $(2 \mathrm{~kb})$ and wet $\left(0.5 \mathrm{wt} . \% \mathrm{H}_{2} \mathrm{O}\right)$ conditions will model results predict olivine as a crystallizing phase (Appendix $\mathrm{H}$ ).

Different mineral phases crystallized from each modeled composition (HMD \& $R R)$. Orthopyroxene is an early crystallizing phase predicted in each model using the RR composition, but never crystallizes during models conducted with the HMD composition (Appendix H). For both primitive PGB compositions, predicted major element concentrations do not reflect some observed values for $\mathrm{MnO}$ and $\mathrm{K}_{2} \mathrm{O}$, and only partially correspond to observed concentrations for $\mathrm{CaO}, \mathrm{TiO}_{2}$, and $\mathrm{P}_{2} \mathrm{O}_{5}$ (wt. \%) (Fig. 3.10). Using the predicted modal abundance of crystallizing phases in MELTS with calculated bulk partition coefficients, concentrations for select trace elements were calculated from each model output. Trace element concentrations calculated from each model border the observed concentrations of $\mathrm{Th}, \mathrm{Ba}$, and $\mathrm{La}$, and could result from mixing of the endmembers (Fig. 3.11). Predicted concentrations of Sc and $\mathrm{Cr}$ do not reflect the majority of observed PGB compositions. Building on this and exploring a variety of trace and major element ratio comparisons, pressure (i.e. depth) and water 
content will result in minimal variability in a variety of trace element ratios, for example $\mathrm{Zr} / \mathrm{Y}, \mathrm{La} / \mathrm{Yb}$, and $\mathrm{Th} / \mathrm{Nb}$ (Fig. 3.12).

Finally, the most conspicuous differences between these two primitive PGB endmembers is the enrichment of light rare earth elements (LREE) in the RR composition relative to the HMD composition (Fig. 3.8). To determine if this LREE enrichment of the RR group samples could occur as a consequence of fractionation from the HMD as a parent melt, REE concentrations were calculated between 10 to $50 \%$ fractionation, in increments of $10 \%$. For each element, bulk partition coefficients were calculated from predicted modal abundance of crystallizing phases at each fractionation increment (i.e. melt fraction) (Fig. 3.8). Calculated REE concentrations of both compositions, each at $10 \%$ fractionation increments, were then normalized to CI-Chondrite The overall slope of each composition is not significantly influenced, and the resulting REE pattern within each primitive group remains distinct (Fig. 3.8).

\section{Evaluating Crustal Contamination}

To determine if assimilation of cratonic crustal material was playing a role in the petrogenesis of PGB lavas and dikes across its distribution area, $\mathrm{K} / \mathrm{P}$ and $\mathrm{K} / \mathrm{Ti}$ are plotted against sample longitude (Fig. 3.14). These ratios are sensitive to minor additions of melting felsic plutonic rocks, such as the Idaho Batholith (the potential contaminant to the Grande Ronde Basalts) and granodiorites and tonalites of Cretaceous stitching plutons. Both ratios $\mathrm{K} / \mathrm{P}$ and $\mathrm{K} / \mathrm{Ti}$ will be modified if felsic plutonic material is assimilated, as $\mathrm{K}$ is concentrated in felsic material while $\mathrm{P}$ and Ti are progressively depleted as a result of apatite and ilmenite fractionation, respectively. Additionally, if felsic plutonic rocks were assimilating, this should also be visible in other geochemical 
parameters such as $\mathrm{SiO}_{2}$, numerous incompatible elements (i.e. $\mathrm{Rb}, \mathrm{Nb}$, $\mathrm{La}$, etc.), and radiogenic and oxygen isotopic data. Incompatible elements and isotopic data exhibit no evidence of assimilated granitic material. Finally, in the spatial extent of analyzed PGB samples, neither $\mathrm{K} / \mathrm{P}$ or $\mathrm{K} / \mathrm{Ti}$ reflects a definitive or systematic shift with changing longitude, especially in context to the known locations of nearby plutonic rocks (Fig. 3.14).

The Izee "terrane" is determined to be a tectonostratigraphic unit that represents distal basin sediments (LaMaskin et al., 2008), and basaltic lavas and dikes of the PGB erupted through their exposure area (Fig. 3.15). This was once considered its own terrane similar to the Baker, Wallowa, and Olds Ferry terranes until it was determined that it did not form elsewhere prior to accretion (Dickinson and Thayer, 1978; Dickinson, 1979; Dorsey and LaMaskin, 2007; LaMaskin et al., 2008; 2011). The 'Izee’ tectonostratigraphic unit is Triassic to Jurassic in age and represents a regional overlap assemblage that can be correlated to other marine strata in the Blue Mountains Province and cap older terranes (Dorsey and LaMaskin, 2007; Schwartz et al., 2010; 2011). It is dominated by turbidites and other fore-arc basin deposits which unconformably overlie the Olds Ferry and the Baker terranes (White et al., 1992). Part of a once large oceanic arc complex, the Baker and the Wallowa terranes developed together in a Paleozoic island arc before a shift in subduction moved volcanism in the late Triassic to the Olds Ferry terrane (White et al., 1992). Limited volcanism occurred during the middle Jurassic in the Blue Mountains while erosion of the Olds Ferry terrane provided sediment for the Izee terrane which sat in an intra-arc basin between the Wallowa and Olds Ferry terranes. 
Compositions of Izee metasediments relative to all PGB samples are plotted on $\mathrm{Ba} / \mathrm{Th}$ versus $\mathrm{La} / \mathrm{Sm}$ (normalized), which is often used to help unravel influences of oceanic crust compared with added sediment (Fig 3.16) (Elliot, 2005). The addition of such sediment into a magma is important to evaluate, as a volumetrically minor amount of sediment $(\sim 2-3 \%)$ can dramatically alter the most incompatible elements of an erupting basalt (Elliot, 2003). In order to investigate whether metasediments sourced from the Izee formation could result in the observed geochemical signatures, a simple mixing model is used.

Models were done with the following mixing calculation:

$$
m=x A+B(1-x)
$$

Different mixing compositions were investigated at 2, 5, 10, 15, and 20\% (x) where (A) is a primitive PGB composition (i.e. HMD or RR), (B) is and the average bulk composition for Izee metasediments, and (m) is the resulting contaminated PGB composition. The objective was to determine if assimilation of Izee metasediments (B) could yield observed PGB compositions (Wolff et al., 2008) (Sun and McDonough, 1989) (Fig. 3.15). Results of this modeling indicate that contamination of Izee argillitic material would not modify sufficiently concentrations of many HREE, such as Tb, Dy, $\mathrm{Yb}$, and Lu. Patterns for all PGB compositions do not reflect large depletions (i.e. deep trough) in $\mathrm{Nb}$ and Ta concentrations on a mantle normalized trace element diagram (Fig. 3.15). Concentrations of HREE and HFSE in PGB samples could not be produced from 
assimilation of Izee metasedimentary material, thus additional processes need to be invoked to produce the observed compositional array in PGB rocks.

\section{DISCUSSION}

\section{Similarities to Mafic Lavas of the Strawberry Volcanics}

Both Steens Basalt and PGB share some chemical characteristics with the coeval basalts of the Strawberry Volcanics, which are spatially adjacent to the original mapped extent of the PGB (Figs. 3.2, 3.3). Mafic lavas and dikes of the Strawberry Volcanics are related to the CRBG in both time and space and share a chemical affinity to the Steens Basalt (Steiner, 2015; Steiner and Streck, 2018) (Fig 3.2), but spatially are interpreted to interfinger with PGB near Strawberry Mountain (Thayer, 1957; Steiner and Streck, 2015). Basalts and andesites of the Strawberry Volcanics are both tholeiitic and calcalkaline in composition, but trend back to a common basaltic parental composition, indicating there is no primary or primitive calc-alkaline basalt (Steiner, 2015). This parental magma is tholeiitic and the result of melting of a mantle source previously metasomatized during an earlier subduction phase, and more evolved calc-alkaline basaltic andesites and andesites are the result of crustal assimilation and magma mixing (Steiner, 2015; Steiner \& Streck, 2018). While the PGB and basalt of the Strawberry Volcanics reflect distinctive elemental patterns, on a mantle-normalized trace element diagram, both units exhibit a similar Ti trough (Steiner \& Streck, 2018) (Figs. 3.3). A metasomatized arc-mantle source has been proposed as a significant contributing source of PGB magmas (Wolff et al., 2008), and based on the geochemical variability in PGB 
further south, there is a potential for a spatially changing mantle component that also influenced basalts of the Strawberry Volcanics.

Basaltic lavas north of John Day, Oregon exhibit compositional patterns that reflect similarities to both the PGB and basaltic lavas of the Strawberry Volcanics (Fig. 3.18). These lavas were originally mapped as PGB (Brown and Thayer, 1966), but analyses of over 10 lava flows in this region show a spatially variable geochemical signal. Moving approximately $20 \mathrm{~km}$ 's along a west to east trajectory toward Strawberry Mountain, sampled lava flows from five locations illustrate a progressively changing geochemical signal that is most similar to PGB to the west, and basalts of the Strawberry Volcanics to the east (Fig. 3.18). Moving east, sampled basaltic compositions become slightly more depleted in the lesser incompatible elements, relatively enriched in $\mathrm{Sr}$, and typically reflect more HFSE depletion than PGB on mantle normalized incompatible element diagram (Fig. 3.18). These samples do not have comparable Mg\#'s, but the increasing enrichment moving east is not a function of sample evolution as there is no systematic decrease in Mg\# with sample location (Fig. 3.18E).

Sampled lava flows from both locations near (B) deviate from the average composition of the PGB, and reflect some geochemical similarities to basalts of the Strawberry Volcanics, such as elevated mid-incompatible elements. Sampled lava flows from location $(\mathrm{C})$ are from the top of a ridge north of John Day and all three basaltic lavas reflect compositions akin to the Strawberry Volcanics, such as a muted $\mathrm{Nb}-\mathrm{Ta}$ trough, elevated mid-incompatible elements, and a deeper $\mathrm{Zr}-\mathrm{Hf}$ trough. None of these lavas exhibit a Ti-trough on a mantle-normalized trace element diagram (Fig. 3.18E), which is different than most PGB and basalts of the Strawberry Volcanics. This transition 
in geochemical signals of mid-Miocene basalt indicates that a contributing metasomatized mantle source can yield spatially gradational signals.

\section{Evidence of a Contaminated Mantle?}

Lava flows and dikes of the PGB contain the lowest ${ }^{87} \mathrm{Sr} /{ }^{86} \mathrm{Sr}$ ratios of other mainphase formations of the CRBG (Figs. 3.6, 3.7). When combined with elevated concentrations of $\mathrm{Ba}$ and overall high LILE/HFSE ratios, these characteristics have been used to argue sourcing from a back-arc type mantle (Wolff et al. 2013). Previous petrogenetic modeling suggests that low ${ }^{87} \mathrm{Sr} /{ }^{86} \mathrm{Sr}$ ratios $(<0.7030-0.7034)$ are characteristic of early and less modified PGB lavas, and any relative increase in ${ }^{87} \mathrm{Sr} r{ }^{86} \mathrm{Sr}$ ratios was attributed to crustal contamination (Carlson, 1984; Brandon et al., 1993; Wolff et al., 2008; Wolff \& Ramos, 2013). Relative to the existing PGB stratigraphy, low ${ }^{87} \mathrm{Sr} /{ }^{86} \mathrm{Sr}$ ratios $(<0.7032)$ are observed in only three PGB samples: a Twickenham Basalt flow, a Dayville Basalt flow, and a high-MgO dike (Bailey, 1989; Brandon and Goles, 1995; Wolff et al., 2008). Higher ${ }^{87} \mathrm{Sr} /{ }^{86} \mathrm{Sr}$ ratios are observed in some of the lavas of the youngest PGB subunit, the Dayville Basalt, however ${ }^{87} \mathrm{Sr} /{ }^{86} \mathrm{Sr}$ ratios in the Dayville Basalt range from 0.703087 to 0.703713 , almost the full range of the entire PGB (Bailey, 1989; Wolff et al., 2008). In contrast, a relatively enriched sample $\left({ }^{87} \mathrm{Sr} /{ }^{86} \mathrm{Sr} 0.703691\right)$ of this study (CAH15-007, RR group) is among the most primitive PGB samples (Fig. 3.6). Another relatively primitive PGB sample (DM255B, Mg\# 57.4) also has a relatively enriched ${ }^{87} \mathrm{Sr} /{ }^{86} \mathrm{Sr}$ ratio of 0.703757 . This sample location at Dooley Mountain represents the northeastern extent of the added PGB distribution and clusters with other samples of the RR group in isotopic space (Fig. 3.6). 
The previous reported $\delta^{18} \mathrm{O}$ values from groundmass for the PGB ranged from 5.6 to $6.1 \%$, where stratigraphically lower basalts of the PGB have the lowest $\delta^{18} \mathrm{O}$ values, and stratigraphically higher lavas have slightly elevated $\delta^{18} \mathrm{O}$, up to $6.1 \%$ (Carlson, 1984; Brandon et al., 1993) (Fig. 3.9). This study notes higher $\delta 180$ values in samples with younger ages, in agreement with observed increases with stratigraphy from earlier studies (i.e. Brandon et al., 1993) (Fig. 3.9). Increases in $\delta^{18} \mathrm{O}$ values with time could be generated by two processes, magmatic evolution and crustal contamination. Fractionation of mafic phases (i.e olivine, clinopyroxene and plagioclase) from a basaltic magma should minimally $\left(\sim 0.2 \%\right.$ ) increase $\delta^{18} \mathrm{O}$, assuming a starting composition of $6.0 \%$ in the basalt (Bindeman, 2008). During magmatic evolution $\delta^{18} \mathrm{O}$ increases and become isotopically heavier in minerals with more covalent bonds, yielding lower $\delta^{18} \mathrm{O}$ in more mafic phases and higher $\delta^{18} \mathrm{O}$ in the remaining melt (Bindeman, 2008). $\delta^{18} \mathrm{O}$ ratios also increase as a result of crustal contamination, as most continental rocks have $\delta^{18} \mathrm{O}$ ratios > 6\%. Observed increases in $\delta^{18} \mathrm{O}$ values in more primitive PGB lavas are then more likely a result of contamination rather than fractional crystallization.

Assuming these higher PGB groundmass $\delta^{18} \mathrm{O}$ values (6.12 and 6.68\%) are representative of both RR endmember samples (i.e. CAH15-007, DM255B in Table 3.3), the question becomes if this contamination occurred in the source, or later as the magma traversed the crust. The most enriched $\delta^{18} \mathrm{O}$ signatures are from two primitive samples of the RR group (CAH15-007 and DM255B, respectively). Both samples are groundmass separates but have undergone acid leaching following ${ }^{40} \mathrm{Ar} /{ }^{39} \mathrm{Ar}$ procedures to remove excess alteration which could lead to misleading (i.e. elevated) values. This observation 
is unique relative to other $\mathrm{CRBG}$ units which often have elevated $\delta^{18} \mathrm{O}$ with lower $\mathrm{MgO}$ content (i.e. Grande Ronde Basalt).

Addition of sediment to magma during crustal contamination affects the $\mathrm{Sr}$ isotope ratio less than addition of 'sediment' to the mantle through subduction zone processes (James, 1981). There is no ${ }^{87} \mathrm{Sr} /{ }^{86} \mathrm{Sr}$ data for Izee material, but $\mathrm{Nd}$ isotopic data yields $\varepsilon N d$ values between -4 to 0 , suggesting arc material that is compositionally evolved (LaMaskin et al., 2008; LaMaskin, 2013). Argilleous and metaplutonic rocks of the Baker Terrane have initial $\varepsilon N d$ values between -7.8 to +8.5 (Schwartz et al., 2010). For $\varepsilon N d$ values between -4 to 0 , targeting a similar range as Izee rocks, the Baker Terrane contains ${ }^{87} \mathrm{Sr} /{ }^{86} \mathrm{Sr}$ ratios between approximately 0.705-0.707 (Schwartz et al., 2010). Assuming a comparable inverse correlation between ${ }^{87} \mathrm{Sr} /{ }^{86} \mathrm{Sr}$ and $\varepsilon N d$ value, these data for other terrane rocks of eastern Oregon can be applied as a first order to Izee rocks. $\delta^{18} \mathrm{O}$ values for Izee samples are also approximated to be $>9$ as is common for most clays and clastic material (Bindeman, 2008).

To help determine if crustal contamination originated from melting a contaminated mantle source or subsequently to melting, as PGB magmas are contaminated in the crust, $\delta^{18} \mathrm{O}$ and ${ }^{87} \mathrm{Sr} /{ }^{86} \mathrm{Sr}$ are plotted against one another, following James (1981) (Fig. 3.19). Izee samples are illustrated as a range, due to approximated values. A 1:1 mixing line originating from any place within the Izee contaminant field, to a primitive mantle source composition $\left(\delta^{18} \mathrm{O}\right.$ and ${ }^{87} \mathrm{Sr} /{ }^{86} \mathrm{Sr}$ values of 5.5 and 0.703 respectively), results in most samples of PGB composition plotting on the right-hand-side of this divide (Fig. 3.19). It is difficult to draw a definitive conclusion as the crustal composition is not precisely known, but this does suggest that both source contamination 
and crustal contamination play a role in petrogenesis of PGB magmas. Samples of the HMD endmember may represent source contamination of a depleted mantle, whereas the RR endmember does represent a more enriched composition but experienced subsequent contamination.

\section{Parental Magmas and Implications for Mantle Sources}

The modeled HMD composition is sourced from two dikes mapped in the Monument Dike swarm, originally interpreted as compositionally dissimilar to any CRBG geochemical subunit (samples D-16 and D-17 of Fruchter and Baldwin, 1975). Although there is no data, earlier studies had also reported basaltic lavas of a similar high-MgO (and low $\mathrm{TiO}_{2}$ ) composition in Flat Creek, approximately $20 \mathrm{~km}$ southeast of the type locality (Thayer and Brown, 1966; D. Swanson, 1973; 2019, personal commun.)(Fig. 3.1). Both of these locations (D-16/-17, and the Flat Creek section) were targeted as part of this study to gain context of sample exposures and field relationships. Multiple dikes were sampled at the mapped location of D-16/-17, along with basaltic outcrops exposed at the Flat Creek section. None of the samples taken from the dikes nor sampled lavas along Flat Creek reflected a geochemical composition characterized by elevated $\mathrm{MgO}$ and depleted $\mathrm{TiO}_{2}$ (wt.\%). Furthermore, in most geochemical parameter space there are only a sparse number of samples between the high-MgO dikes and the rest of the PGB (Figs. 3.10, 3.11). While similar in spatial extent and orientation to PGB dikes in the Monument swarm, these high-MgO basaltic compositions are spatially localized and likely not a volumetrically dominant parental magma to the PGB.

The two defined primitive groups (HMD \& RR) represent PGB endmembers which are distinct in both trace element and isotopic space with minimal overlapping 
characteristics (Fig. 3.7). Isotopic data suggest that the PGB samples define two populations of ${ }^{87} \mathrm{Sr} /{ }^{86} \mathrm{Sr}$ ratios, as demonstrated by samples representative of both the RR and HMD groups. Plots of major and trace element data similarly suggest that samples of both groups show distinct compositional differences. Although, sample CAH15-007 plots closer to the HMD group in most major and trace element space, but in isotopic geochemical space this sample clusters with the RR group (Fig. 3.7). These relative enrichments in ${ }^{87} \mathrm{Sr} /{ }^{86} \mathrm{Sr}$ could be the result of contamination, but also reflect a lessdepleted source magma.

Distinct geochemical and isotopic traits distinguish samples from the RR group from samples of the HMD group and suggest two different primitive sources. Compared with other isotopic ratios such as ${ }^{143} \mathrm{Nd} /{ }^{144} \mathrm{Nd}$ or ${ }^{206} \mathrm{~Pb} /{ }^{204} \mathrm{~Pb}$ (Fig.3.7 C, D), samples of both groups exhibit a wider range of ${ }^{87} \mathrm{Sr} /{ }^{86} \mathrm{Sr}$ ratios. For example, ${ }^{87} \mathrm{Sr} /{ }^{86} \mathrm{Sr}$ ratios range between 0.7030-0.7034 in HMD group samples, and 0.7035-7038 in RR group samples. This variability is not observed in ${ }^{143} \mathrm{Nd} /{ }^{144} \mathrm{Nd}$ ratios, as the ratio is consistent in samples of the HMD group $(\sim 0.5130)$ and the RR group $(\sim 0.5129)$. Samples of the RR group contain higher LREE concentrations and $\mathrm{Zr} / \mathrm{Y}$ values at higher ${ }^{87} \mathrm{Sr} /{ }^{86} \mathrm{Sr}$ ratios (i.e. $>0.7035$ ), suggesting that some PGB magmas already contained slightly enriched ratios (Fig. 3.7).

Both the RR and HMD groups represent some of the most primitive basalts sampled within the PGB (Mg\# >57). Samples of the HMD group plot closer to the $\mathrm{C} 1$ depleted mantle component of Carlson (1984), while samples of the RR group reflect a more enriched composition (Fig. 3.7 C, D). Magmatically evolved PGB samples are also consistent with a petrogenetic model invoking two different mantle sources, as 
compositional variability at a given $\mathrm{Mg \#}$ cannot be explained by fractionation or contamination alone.

\section{Modification of PGB Magmas}

Distinguishing processes which result in incompatible element enrichment is difficult, especially when processes have comparable geochemical consequences. Influence from a fluid-fluxed mantle or the addition of sediment to a melt can yield comparable geochemical and isotopic characteristics. Both LILE and LREE, although to a lesser extent, can be enriched as a result of slab fluxing in the mantle or addition of sediment in the crust, so both modification scenarios have to be considered. Samples of both primitive PGB groups (HMD and $\mathrm{RR}$ ) contain slightly elevated $\mathrm{Ba} / \mathrm{Nb}$ ratios (i.e. 60) relative to more evolved PGB samples ( $\mathrm{Ba} / \mathrm{Nb} 50-100)$ (Fig. 3.2B). With respect to the RR group, all four sampled basaltic lavas from along Rattlesnake Road were candidates to represent a parental PGB composition (Mg\# 58-59) for modelling in MELTS. However, these four lavas contain highly variable $\mathrm{Ba} / \mathrm{Nb}$ ratios, ranging from 39 to 100 , almost the full range observed in all PGB samples. The variability in $\mathrm{Ba} / \mathrm{Nb}$ values within the same inferred mantle source (RR group) suggests that this source itself varied spatially, and that it is not a result of contamination.

The degree of crustal contamination is partially restricted due to the rapid ascent rate of PGB magmas (Brandon et al., 1993). Earlier modeling tried to calculate the amount of contamination using an isotopic component which represents the crust in the Blue Mountains Province (Paleozoic accreted terranes) and a redefined C1 depleted mantle (Carlson, 1984; Bailey, 1989; Brandon et al., 1993). To achieve observed radiogenic $\mathrm{Sr}$ and $\delta^{18} \mathrm{O}$ values, Brandon et al. (1993) estimated between 8-21\% crustal 
contamination which was consistent with the estimate of Carlson (1984). Although the bulk of these compositions provide little isotopic leverage when compared to the CRBG, a more plausible contaminant to PGB magmas is accreted terrane material. If the LILEenrichment in PGB lavas are a result of sediment input, metasedimentary Izee rocks are the most representative composition.

Trace element modelling suggests crustal contamination with Izee metasedimentary material could not yield the observed compositional patterns in some incompatible elements in samples of the PGB, such as Nb, Ta, and some HREE's (Fig. 3.15). Observed $\mathrm{Zr} / \mathrm{Y}$ ratios in $\mathrm{PGB}$ lavas and dikes are highly variable, ranging from $\sim 2$ to 4.5 (Fig. 3.7). Both $\mathrm{Zr}$ and $\mathrm{Y}$ are similarly incompatible with partition coefficients that make them difficult to decouple during magmatic evolution. Variable $\mathrm{Zr} / \mathrm{Y}$ values at high $\mathrm{MgO}$ suggests more than one contributing mantle source, as these ratios distinguish both primitive PGB groups ( $\mathrm{Zr} / \mathrm{Y}>2.5$ in $\mathrm{RR}, \mathrm{Zr} / \mathrm{Y}<2.5$ in $\mathrm{HMD}$ ) (Fig. 3.10). If changes in $\mathrm{Zr} / \mathrm{Y}$ is a result of changes in the mantle, the RR source is more heterogeneous. This is because samples defining the RR group exhibit a larger range in $\mathrm{Zr} / \mathrm{Y}$ ratios than samples of the HMD group (similar to the variability of $\mathrm{Ba} / \mathrm{Nb}$ ratios mentioned above).

High Mg basalts of the PGB contain Sc concentrations between 30-40 ppm, meanwhile more evolved PGB samples contain Sc concentrations between 40-50ppm. Results of every MELTS model does not predict an increase in Sc, but a decrease with magmatic evolution. This combined with higher than predicted $\mathrm{Cr}$ concentrations, suggests that fractionation of clinopyroxene was not a dominating process in the formation of PGB basalts. Instead, the elevated concentrations of both of these trace elements indicates crystallization of clinopyroxene and potentially orthopyroxene was 
delayed or suppressed (Fig. 3.11). The arrival of clinopyroxene on the liquidus can be delayed when fractionation occurs at lower pressures (Takahashi and Kushiro, 1983). In order for Sc content to steadily rise it needs to remain incompatible and that could be possibly achieved by episodic magmatic recharge at low pressures $(<3 \mathrm{~kb})$ that may buffer basalt magmas at conditions prior pyroxene crystallization. This may also explain highly variable $\mathrm{Cr} / \mathrm{Ni}$ ratios among $\mathrm{PGB}$ magmas.

\section{Petrogenetic Relationships to Other CRBG Formations}

PGB shares the most geochemical and isotopic characteristics with the Steens Basalt, with comparable ${ }^{87} \mathrm{Sr} /{ }^{86} \mathrm{Sr}$ ratios $(0.7035-0.7038)$. While observed $\delta^{18} \mathrm{O}$ values in PGB samples are not anomalously low, they are slightly depleted relative to Steen Basalt. Reported $\delta^{18} \mathrm{O}$ values for Steens Basalt range between 5.91-6.75\% ( $\left.\mathrm{n}=17\right)$, excluding one outlier at $8.5 \%$ (Moore, 2018). Reported $\delta^{18} \mathrm{O}$ values for PGB range between 5.28-5.99\%o ( $n=17$, Table 3.3), excluding two values $>6 \%$ which is generally representative of the mantle. Within basaltic lavas and dikes of the $\mathrm{CRBG}, \delta^{18} \mathrm{O}$ values below $\sim 5.9 \%$ are proposed to result from hydrothermal alteration by heated groundwater (Bindeman et al., 2020). With the majority of $\delta^{18} \mathrm{O}$ values in PGB consistently below the average mantle, which differs from other CRBG formations, an alternative consideration could be exposure to hydrothermal processes. However, this interpretation seems unlikely given the correlation of $\delta^{18} \mathrm{O}$ values to ${ }^{87} \mathrm{Sr} /{ }^{86} \mathrm{Sr}$, the minor depletion of $\delta^{18} \mathrm{O}$ values, and the large spatial extent and age range of analyzed PGB samples.

Sampled PGB lavas from Pole Creek in the Malheur Gorge have isotopic compositions that are more similar to the Imnaha Basalt with ${ }^{87} \mathrm{Sr} /{ }^{86} \mathrm{Sr}$ ratios $>0.7039$ and ${ }^{143} \mathrm{Nd} /{ }^{144} \mathrm{Nd}$ ratios $<0.5129$. However, major and trace element concentrations of these 
two samples more closely resemble the PGB (Fig. 2.10B). These are not the only flows that have characteristics of both PGB and Imnaha Basalt. Lower American Bar flows of Imnaha Basalt exposed at Dug Bar (Fig. 3.1) exhibit geochemical features that are better classified as PGB. At least four flows at this location contain the lowest abundances of incompatible trace elements and ${ }^{87} \mathrm{Sr} /{ }^{86} \mathrm{Sr}$ ratios $(<0.7039)$ of any of the Imnaha Basalt lavas (Fig. 3.6). This observation reinforces the notion that the earliest erupted American Bar lavas have the most depleted mantle contribution of the Imnaha lavas (Wolff \& Ramos, 2013), and are likely more geochemically (Cahoon et al., 2020), and even isotopically similar to the PGB (Fig. 3.7).

\section{Two Temporal Pulses of Magmatism}

Eruptive activity for the PGB spans $1.4 \mathrm{Ma}$, as evidenced by numerous highprecision ArAr dates from samples dispersed across a wide region in eastern Oregon. These ages demonstrate lavas and dikes of the PGB were emplaced during two discrete intervals, a temporal pattern that this research has also identified in main-phase CRBG (Fig. 3.20). Within the PGB, younger ages are often correlated with higher Mg\#, lower Sc (ppm), and decreasing $\mathrm{TiO}_{2}$ (wt. \%) values (Fig. 3.21A-C).

Two of the youngest reported PGB ages represent primitive samples used to characterize the RR group within radiogenic isotope space (samples CAH15-007 and DM255B) (Table 3.2, Fig. 3.7). These samples erupted during the second and later pulse of PGB activity with ${ }^{40} \mathrm{Ar} /{ }^{39} \mathrm{Ar}$ ages between 16.22 and $15.76 \mathrm{Ma}$, and contain the lowest $\mathrm{TiO}_{2}$ values of any of the dated samples (0.914 and 0.99 wt. \%, respectively) (Fig. 3.21). While these two samples are the only dated samples within either identified group (RR or HMD), the other primitive samples which comprise the RR group have stratigraphic age 
control. Multiple basaltic lava flows along Rattlesnake Road both underlie and overlie the rhyolitic Dinner Creek Tuff unit 2, dated at $\sim 15.5 \mathrm{Ma}$ (Streck et al., 2015). The exposures here are faulted, but the section overlies the Dinner Creek Tuff unit 1 and underlies unit 3, dated at 16.16 and 15.5, respectively (Streck et al., 2015). This stratigraphic relationship constrains eruptive age, and suggests these lavas were emplaced between 15.5 and 16.16 Ma. These basaltic lavas along Rattlesnake Road erupted during later pulse of PGB volcanism and contain low $\mathrm{TiO}_{2}$ concentrations ( 0.92-1.11 wt. \%). In addition to samples of the RR group, $\mathrm{HMD}$ samples contain the lowest $\mathrm{TiO}_{2}$ concentrations of any analyzed PGB lava or dike, between $0.72-0.77$ (wt. \%). If these basaltic lavas and dikes do represent two parental components for the PGB, they were not emplaced until the second pulse of PGB eruptive activity (Fig. 3.20).

In addition to the CRBG as a whole, the coeval mid-Miocene tholeiitic basalts and calc-alkaline andesites of the Strawberry Volcanics also exhibit evidence for a subduction component (Robyn, 1979). The amount contributed by this metasomatized source is temporally dependent, as the contribution is highly variable with time. While tenuous, observed $\mathrm{Ba} / \mathrm{Nb}$ ratios for all dated $\mathrm{PGB}$ samples appear to increase within each temporal pulse, respectively (Fig. 3.21D). This supports previous workers observation that there is a cyclical nature to the proportion of depleted mantle on a formation-level, although here a larger input from a LILE-enriched mantle component is noted in the earliest eruptive products (Fig. 3.8). Combining stratigraphic, geochemical, and geochronological data for the PGB, I demonstrate that later erupted basalts of each temporal pulse contain a more primitive (but potentially contaminated) geochemical signature. 


\section{CONCLUSIONS}

Geochemical compositions of the PGB, Steens Basalt, and basalts of the Strawberry Volcanics were influenced by mantle contributions from a subduction-related component, likely from prior slab-sourced fluid fluxing (Brandon et al., 1993; Wolff et al., 2008). In context to the PGB, this contributing mantle source must be spatially widespread and gradational, as lavas and dikes of PGB composition have been identified as far east as Lake Owyhee, and as far south as Hart Mountain, Oregon.

Samples of PGB composition exposed in both the original and extended distribution exhibit petrochemical diversity that trends toward two primitive endmembers in geochemical and isotopic space. MELTS modelling of both endmember compositions (HMD \& RR) demonstrates that PGB geochemical variability cannot be attributed to fractionation processes alone. Evolution of the RR composition can account for a larger degree of the observed PGB trace element concentrations compared to the HMD composition, supporting the observation that samples of the HMD group are spatially localized and limited.

Each group displays distinct trends with magmatic evolution, as seen in major and trace element compositional arrays. The HMD group is more sensitive to pressure fluctuations during fractionation, as exhibited by larger compositional changes between MELTS models conducted at different pressures. Predicted crystallizing phases are also dissimilar, olivine only crystallizes from the HMD composition and orthopyroxene only crystallizes from the RR composition. Results of trace element modelling does not corroborate increasing concentrations of $\mathrm{Sc}$ and $\mathrm{Cr}(\mathrm{ppm})$ with magmatic evolution of natural samples. This could suggest suppression of clinopyroxene (or possibly 
orthopyroxene) fractionation and the continuous recharging of a Sc-enriched melt.

The geochemical diversity of PGB magmas cannot be solely attributed to magmatic fractionation, requiring some modification via crustal contamination. Modelling potential mixing compositions to produce average composition for the PGB, or the HMD group and modelling potential mixing compositions to produce the RR group, bulk compositions for Izee metasedimentary rocks do not reflect similar compositions of the required assimilant. More specifically, Izee rocks exhibit large relative depletions in trace elements such as $\mathrm{Nb}$, Ta, and some HREE's. Mixing models indicate the assimilating material could not have such significant depletions in these elements to produce average PGB compositional patterns on a mantle-normalized trace element diagram. Crustally derived material however does play a role in the generation of PGB, clearly indicated by the observed positive correlation of $\delta^{18} \mathrm{O}$ versus ${ }^{87} \mathrm{Sr} r{ }^{86} \mathrm{Sr}$ and enrichment of various LILE's. Considering additional mantle, magmatic, and surficial processes which influence these geochemical traits, the degree of contamination is likely $<10 \%$, given the majority of PGB contain $\delta^{18} \mathrm{O}$ values below $6 \%$.

Combining geochemical traits, MELTS modelling results, and reported ages for the PGB which range from 15.76 to $17.23 \mathrm{Ma}$, indicates that the most primitive PGB samples erupted during the later episode of PGB volcanic activity. This is also supported by decreases in $\mathrm{TiO}_{2}$ (wt. \%) with time, the opposite of what would be expected with magmatic evolution. On the other hand, a fluid-fluxed mantle component is present in both temporal periods of PGB volcanic activity, and appears to become more significant over time within each discrete pulse. 


\begin{tabular}{|c|c|c|c|c|c|c|c|}
\hline Element & $\begin{array}{c}\text { Valence } \\
(+)\end{array}$ & $\begin{array}{c}\text { Ionic } \\
\text { radius }(\AA \hat{)})\end{array}$ & $\mathrm{CN}$ & $\begin{array}{c}\text { Plagioclase } \\
\text { (D) }\end{array}$ & $\begin{array}{l}\text { Olivine } \\
\text { (D) }\end{array}$ & $\begin{array}{c}\text { Clinopyroxene } \\
\text { (D) }\end{array}$ & $\begin{array}{c}\text { Orthopyroxene } \\
\text { (D) }\end{array}$ \\
\hline $\mathrm{Rb}$ & 1 & 1.61 & 8 & 0.1 & 0.005 & 0.005 & 0.005 \\
\hline $\mathrm{Ta}$ & 5 & 0.64 & 6 & 0.0 & 0.005 & 0.008 & 0.01 \\
\hline $\mathrm{Nb}$ & 5 & 0.64 & 6 & 0.0 & 0.01 & 0.008 & 0.0013 \\
\hline Th & 4 & 1.09 & 9 & 0.1 & 0.01 & 0.010 & 0.01 \\
\hline $\mathrm{Ba}$ & 2 & 1.42 & 8 & 0.2 & 0.001 & 0.001 & 0.005 \\
\hline $\mathrm{La}$ & 3 & 1.16 & 8 & 0.1 & 0.005 & 0.048 & 0.005 \\
\hline $\mathrm{Ce}$ & 3 & 1.14 & 8 & 0.1 & 0.01 & 0.11 & 0.008 \\
\hline $\mathrm{Nd}$ & 3 & 1.11 & 8 & 0.0 & 0.009 & 0.18 & 0.01 \\
\hline $\mathrm{Sm}$ & 3 & 1.08 & 8 & 0.0 & 0.01 & 0.36 & 0.06 \\
\hline $\mathrm{Sr}$ & 2 & 1.26 & 8 & 2.0 & 0.00 & 0.16 & 0.0012 \\
\hline $\mathrm{Eu}$ & 2 & 1.17 & 6 & 0.2 & 0.01 & 0.39 & 0.07 \\
\hline $\mathrm{Tb}$ & 3 & 1.04 & 8 & 0.0 & 0.01 & 0.44 & 0.16 \\
\hline Dy and $Y$ & 3 & 1.03 & 8 & 0.0 & 0.03 & 0.42 & 0.205 \\
\hline $\mathrm{Yb}$ & 3 & 0.99 & 8 & 0.0 & 0.04 & 0.40 & 0.25 \\
\hline Lu & 3 & 0.98 & 8 & 0.0 & 0.08 & 0.40 & 0.3 \\
\hline $\mathrm{Hf}$ & 4 & 0.58 & 4 & 0.01 & 0.001 & 0.26 & 0.1 \\
\hline $\mathrm{Zr}$ & 4 & 0.59 & 4 & 0.01 & 0.0047 & 0.28 & 0.032 \\
\hline $\mathrm{Zn}$ & 2 & 0.74 & 6 & 0.06 & 0.77 & 0.2 & 0.9 \\
\hline Sc & 3 & 0.75 & 6 & 0.014 & 0.4 & 3.94 & 1.3 \\
\hline $\mathrm{Cr}$ & 3 & 0.62 & 6 & 0.12 & 1.4 & 10 & 2.6 \\
\hline
\end{tabular}

CN: coordination number

Data compiled from McKenzie \& O'Nions 1991; Hart \& Dunn 1993; Green 1994; Hauri et al. 1994; Dunn \& 
TABLE 3.2 Summary Table of Picture Gorge Basalt Primitive Endmember Samples Sample Name

$\mathrm{Mg \#}$

${ }^{87} \mathrm{Sr} /{ }^{86} \mathrm{Sr}$

${ }^{143} \mathrm{Nd} /{ }^{144} \mathrm{Nd} \quad$ Age (Ma)

high-MgO dike (HMD) Endmember

\begin{tabular}{|c|c|c|c|c|}
\hline MMB D69A & 65.4 & 0.703400 & 0.512980 & \\
\hline MMB D69B & 64.5 & 0.703066 & 0.513012 & \\
\hline MMB D70A* & 66.1 & 0.703400 & 0.512990 & \\
\hline MMB D70B & 64.1 & & & \\
\hline
\end{tabular}

Rattlesnake Road (RR) Endmember

\begin{tabular}{|c|c|c|c|c|}
\hline DM255B & 57.4 & 0.703757 & 0.512905 & 15.76 \\
\hline CAH15-007 & 64.4 & 0.703691 & 0.512889 & 16.22 \\
\hline CAH17-241A * ${ }^{1}$ & 59.6 & & & \\
\hline CAH17-241B ${ }^{1}$ & 59.5 & & & \multirow{2}{*}{$15.5-16.16$} \\
\hline CAH17-242A ${ }^{1}$ & 57.8 & 0.703565 & 0.512925 & \\
\hline MS-15-18ba ${ }^{1}$ & 58.8 & & & \\
\hline
\end{tabular}

${ }^{1}$ Samples collected along Rattlesnake Road

*Samples used for MELTS modelling 


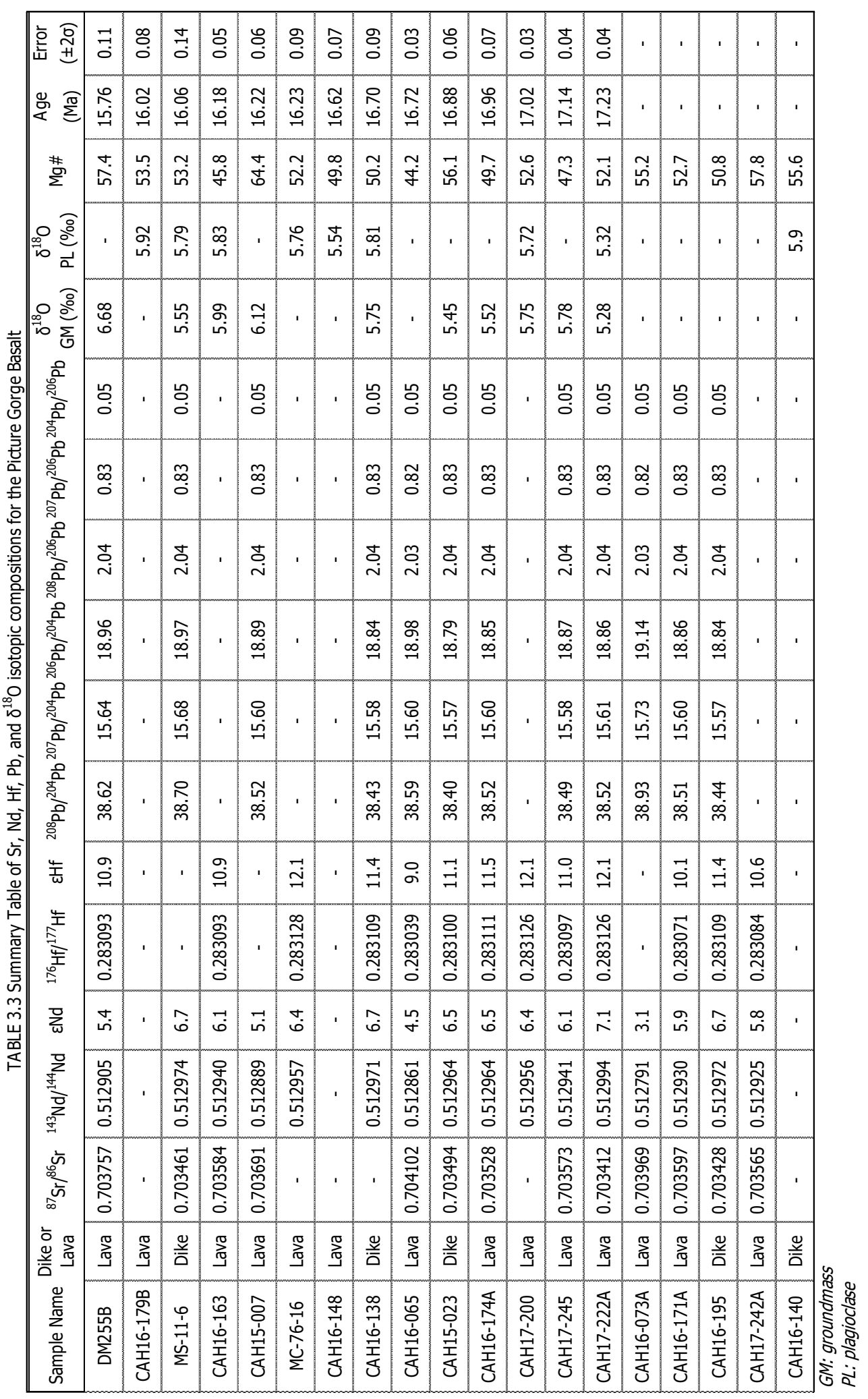




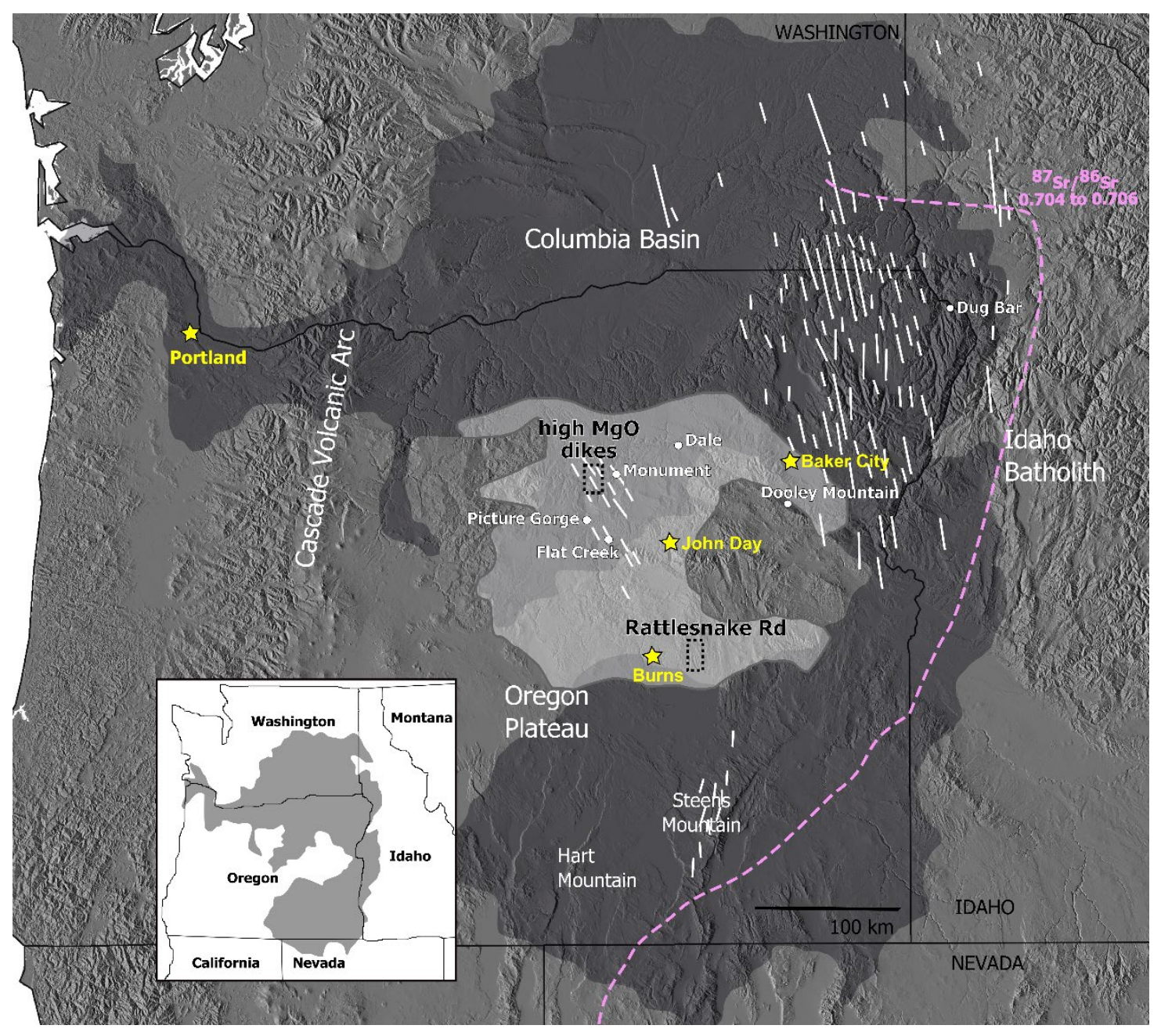

Figure 3.1 Regional map illustrating distribution of the CRBG and extended spatial distribution of PGB lavas. Locations of dikes shown for the Chief Joseph, Steens, and the Monument Dike swarm. High $\mathrm{MgO}$ and Rattlesnake Road highlight sample locations for compositions used in MELTS modelling and definition of PGB compositional endmembers. Dashed $0.704 / 0.706$ line represents the ${ }^{87} \mathrm{Sr} /{ }^{86} \mathrm{Sr}$ contact between accreted terranes and the western margin of the north American craton. Inset map showing distribution of Columbia River Basalt Group in northwestern U.S. with state lines for reference. 


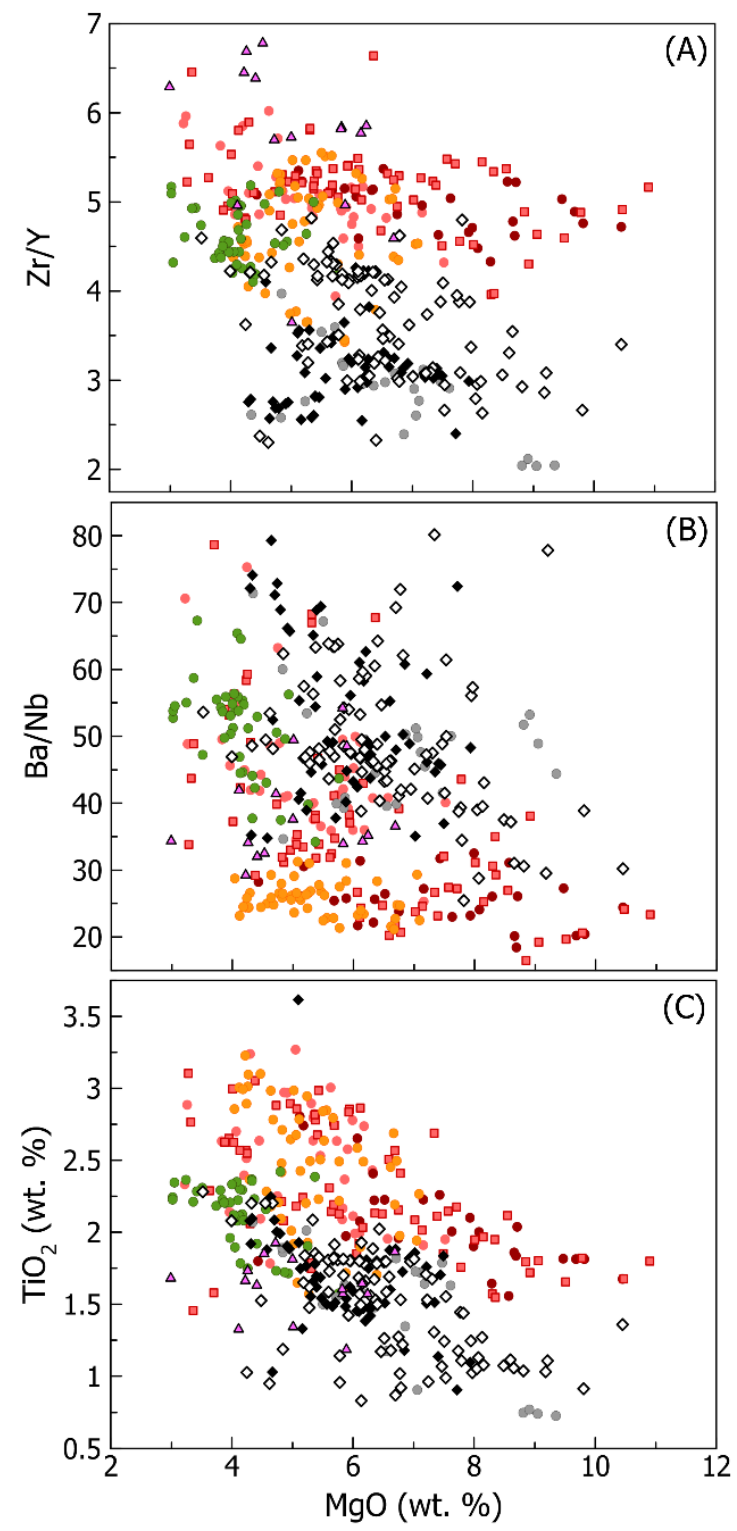

- Grande Ronde Basalt ${ }^{1}$

- Imnaha Basalt 1

- Upper Steens Basalt ${ }^{1}$

- Lower Steens Basalt ${ }^{1}$

$\square$ Steens Basalt, undifferentiated ${ }^{2}$

$\triangle$ Strawberry Volcanics ${ }^{3}$

- PGB ${ }^{1}$

$\checkmark \mathrm{PGB}$, original distribution ${ }^{4}$

$\diamond P G B$, extended distribution ${ }^{4}$

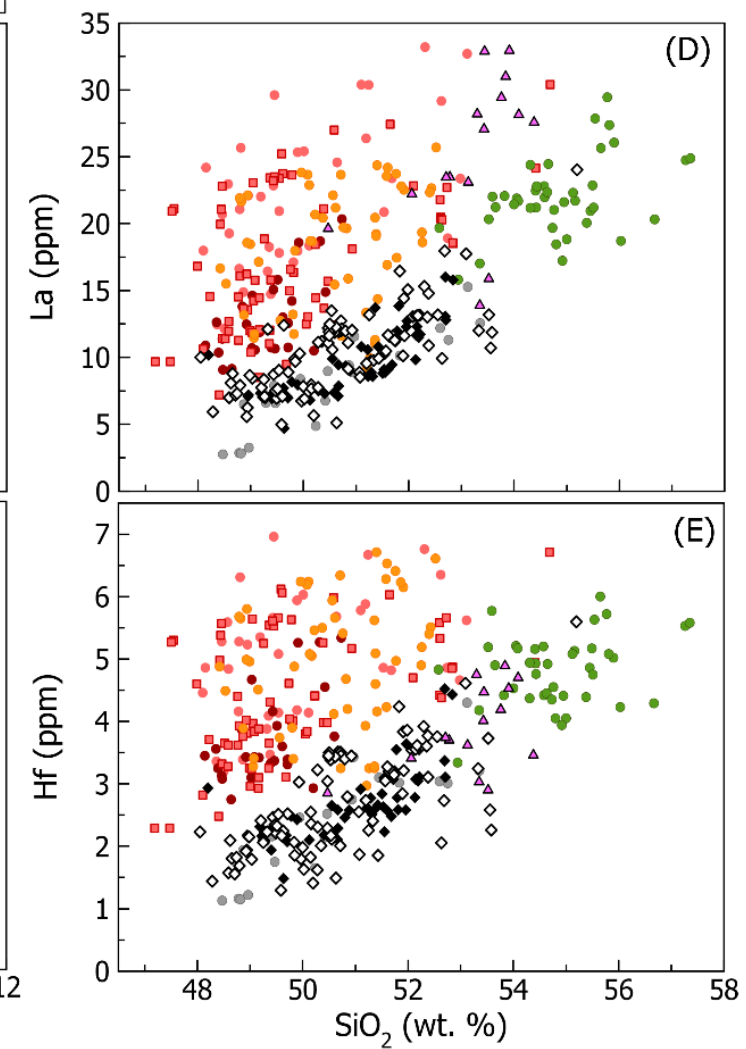

Figure 3.2 Geochemical major and trace elements for PGB relative to all main-phase CRBG. (A) $\mathrm{Zr} / \mathrm{Y}$ (B) $\mathrm{Ba} / \mathrm{Nb}$, and (C) $\mathrm{TiO}_{2}$ (wt. \%) versus $\mathrm{MgO}$ (wt. \%), (D) $\mathrm{La}$ (ppm), and (E) Hf (ppm) versus $\mathrm{SiO}_{2}$ (wt. \%). Samples of PGB are subdivided based on their location, the previously mapped extent of PGB (original distribution) shown with open diamonds or additional locations (extended distribution) shown with solid diamonds. Geochemistry compiled from ${ }^{1}$ Wolff et al (2008), ${ }^{2}$ Moore (2018), ${ }^{3}$ Steiner and Streck (2015), and ${ }^{4}$ this study. 


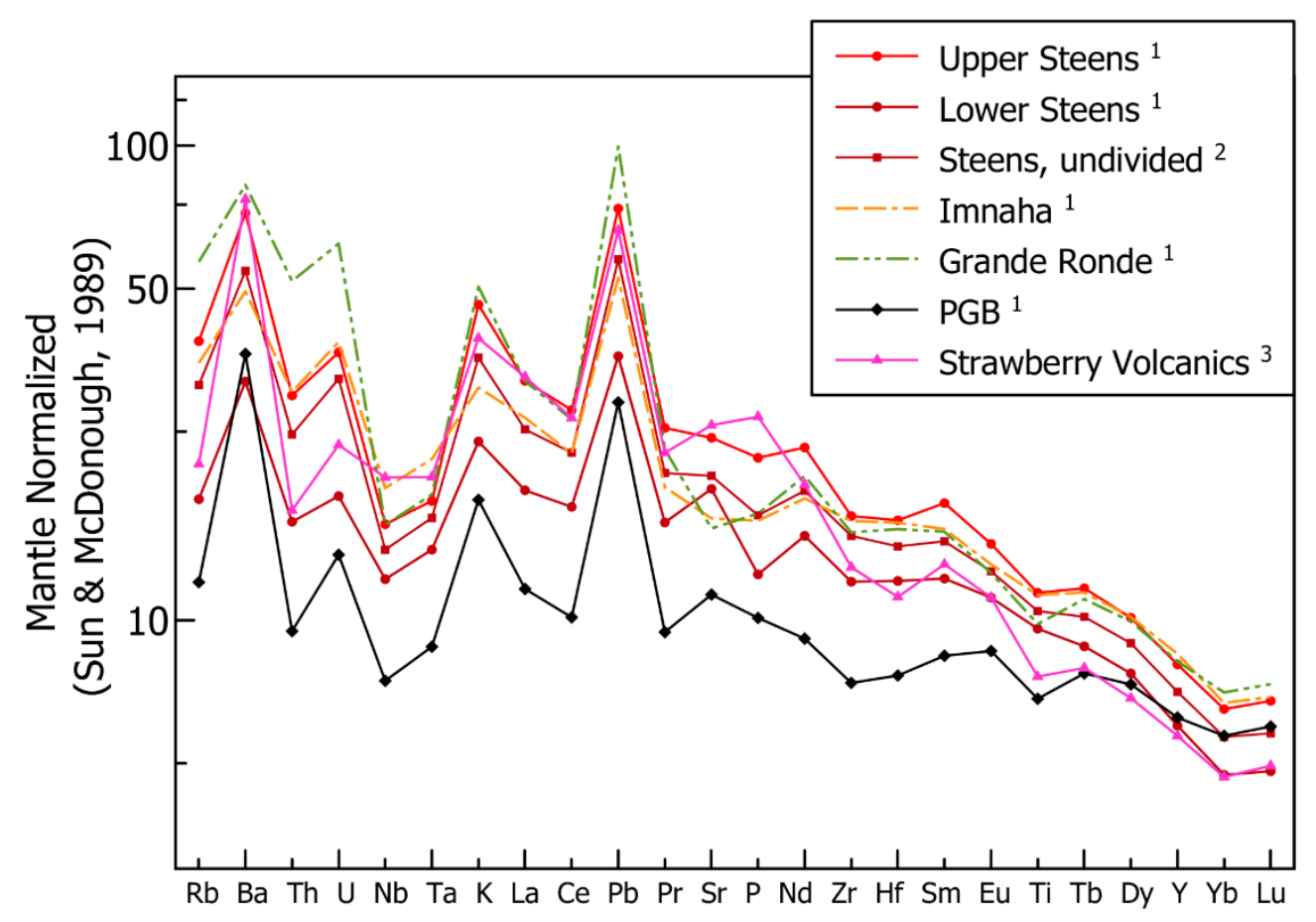

Figure 3.3 Mantle-normalized incompatible element diagram with average compositions for main-phase formations of the CRBG including mafic lavas of the coeval Strawberry Volcanics. Geochemistry compiled from ${ }^{1}$ Wolff et al (2008), ${ }^{2}$ Moore (2018), and ${ }^{3}$ Steiner and Streck (2015). 

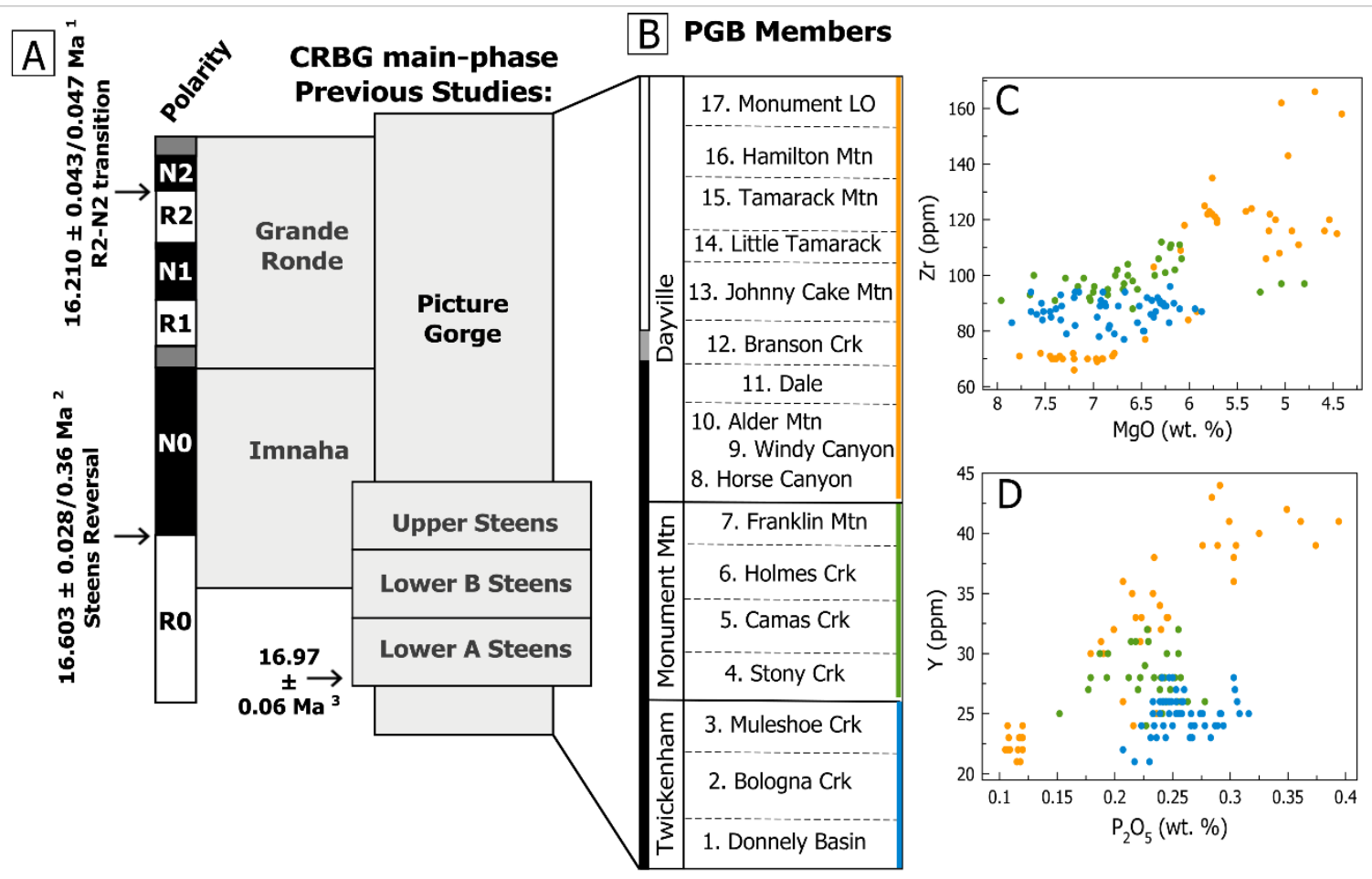

Figure 3.4 (A) Stratigraphic section of main-phase units of the CRBG and the (B) PGB with subunits and members. (C) $\mathrm{Zr}$ (ppm) versus $\mathrm{MgO}$ (wt. \%) and (D) $\mathrm{Y}$ (ppm) versus $\mathrm{P}_{2} \mathrm{O}_{5}$ (wt. \%) for the three identified subunits of the PGB, the Twickenham, Monument Mountain, and Dayville Basalt. Compositions for PGB subunits from Bailey (1989a). 

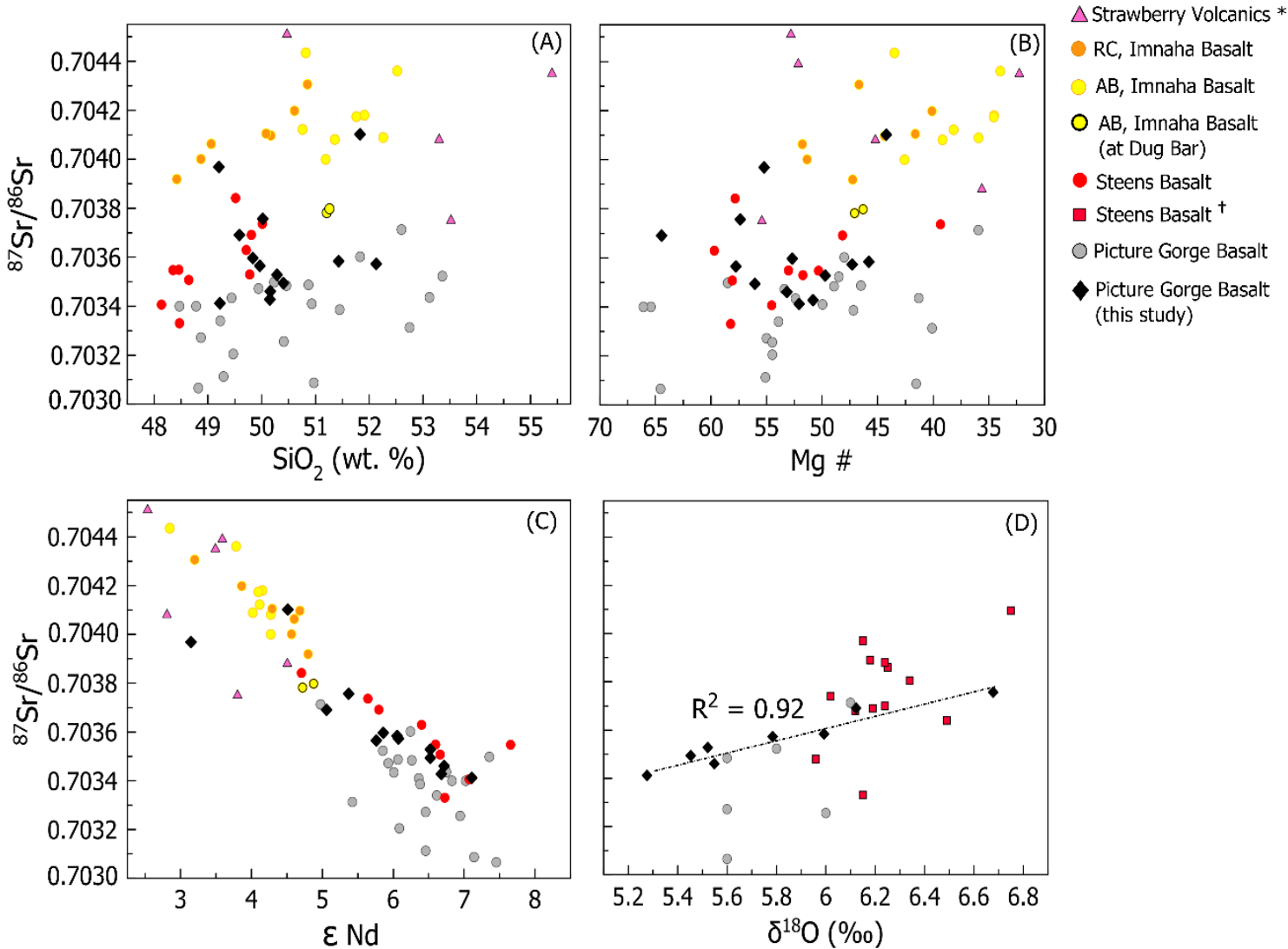

Figure 3.5 ${ }^{87} \mathrm{Sr} /{ }^{86} \mathrm{Sr}$ isotopic ratios versus (A) $\mathrm{SiO}_{2}$ (wt.\%), (B) $\mathrm{Mg} \#$ (C) Epsilon $\mathrm{Nd}$ and (D) $\delta^{18} \mathrm{O}(\%$ ) data for main phase units of the CRBG: PGB, Steens, and Imnaha Basalt (Grande Ronde Basalt not depicted) and basalts and basaltic andesites of the Strawberry Volcanics. Both subtypes of Imnaha Basalt are distinguished, American Bar and Rock Creek, in addition to the American Bar lavas located at Dug Bar which reflect some PGB characteristics. Geochemical data from this study; * Steiner and Streck (2015); $\dagger$ Moore et al (2020); all other isotopic and geochemical data from Wolff et al (2008). 


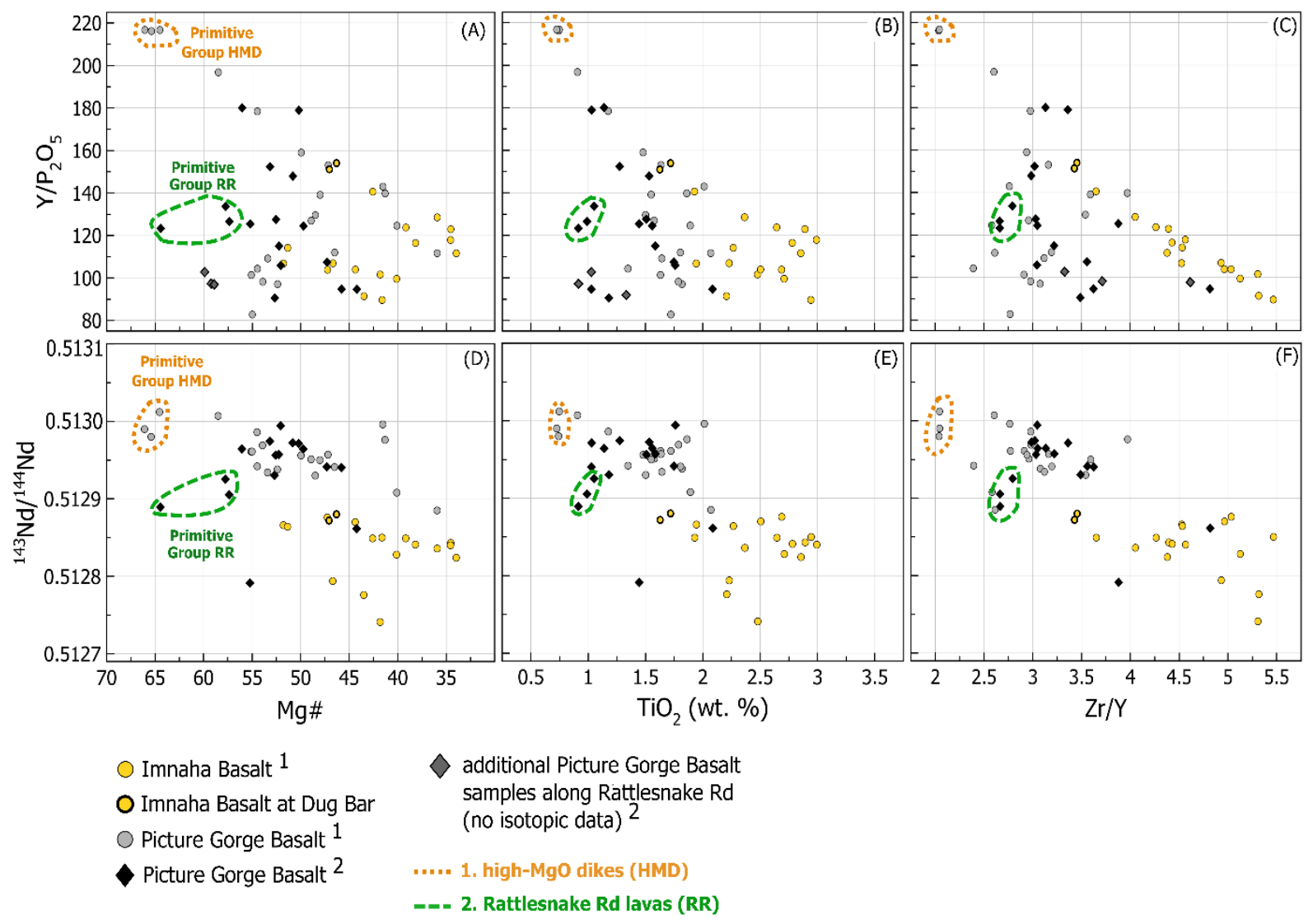

Figure 3.6 Elemental ratio plots to distinguish identified $\mathrm{PGB}$ endmembers. $\mathrm{Y} / \mathrm{P}_{2} \mathrm{O}_{5}$ versus (A) $\mathrm{Mg}$ \#, (B) $\mathrm{TiO}_{2}$ (wt.\%), (C) $\mathrm{Zr} / \mathrm{Y}$, and ${ }^{143} \mathrm{Nd} /{ }^{144} \mathrm{Nd}$ isotopic ratios versus (D) $\mathrm{Mg} \#$, (E) $\mathrm{TiO}_{2}$ (wt.\%), (F) $\mathrm{Zr} / \mathrm{Y}$ for the Imnaha Basalt and PGB main phase units of the CRBG. Both identified PGB endmember compositions, HMD (orange) and RR (green) are noted along with additional PGB lavas located along Rattlesnake Road. These samples are included in the trace element plots for comparison, but do not have isotopic data. Trace element and isotopic data from ${ }^{1}$ Wolff et al (2008) and ${ }^{2}$ this study. 

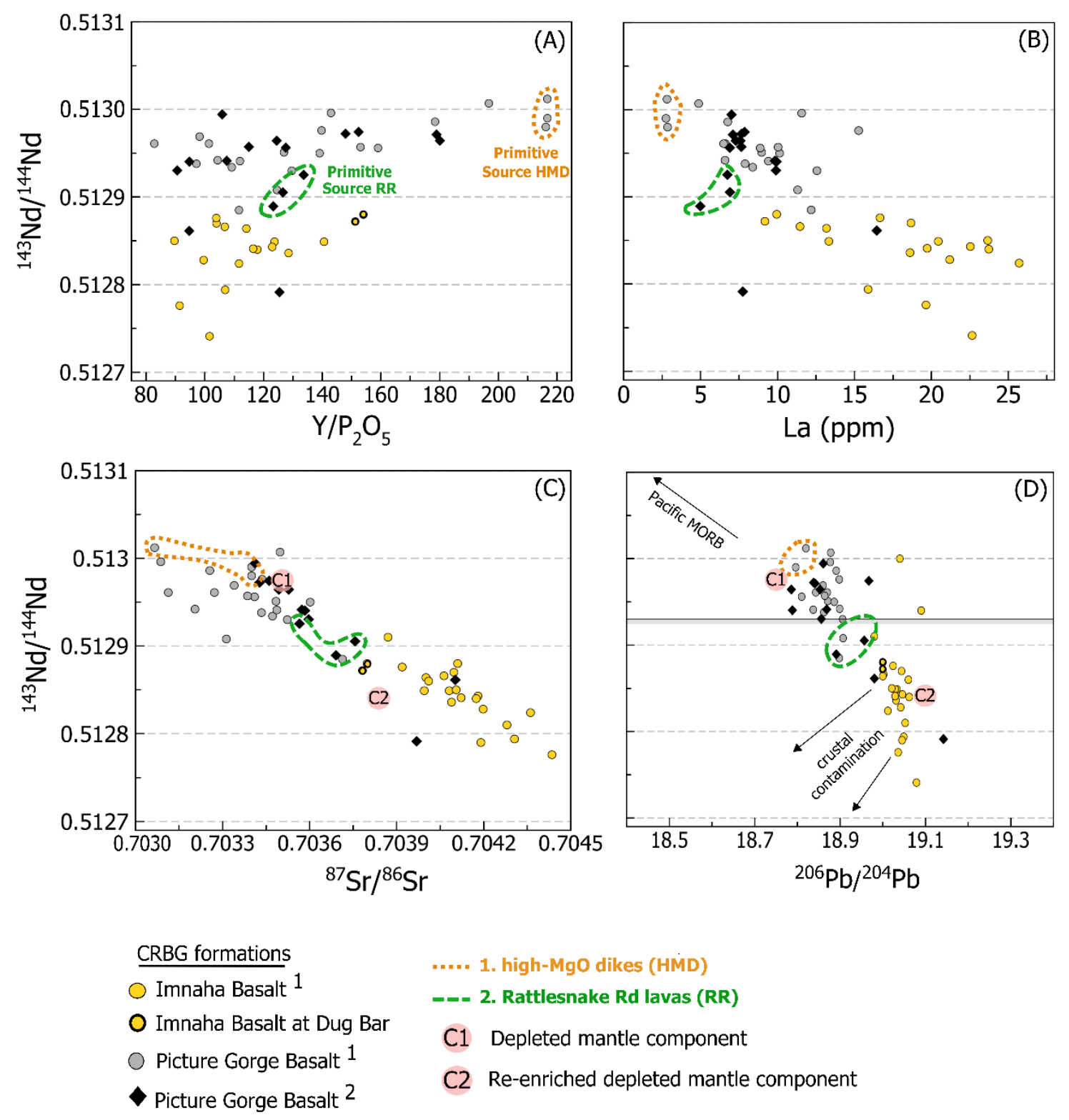

"..." 1. high-MgO dikes (HMD)

- = 2. Rattlesnake Rd lavas (RR)

C1 Depleted mantle component

C2 Re-enriched depleted mantle component

Figure 3.7 Isotopic ratio plots to distinguish identified PGB endmembers. ${ }^{143} \mathrm{Nd} /{ }^{144} \mathrm{Nd}$ isotopic ratios versus (A) $\mathrm{Y} / \mathrm{P}_{2} \mathrm{O}_{5}$, (B) La (ppm), (C) ${ }^{87} \mathrm{Sr} /{ }^{86} \mathrm{Sr}$ isotopic ratios, and (D) ${ }^{206} \mathrm{~Pb} /{ }^{204} \mathrm{~Pb}$ data for the Imnaha Basalt and $\mathrm{PGB}$ main phase units of the CRBG. The $\mathrm{C} 1$ enriched mantle and C2 depleted mantle components of Carlson (1984) are noted on plots (C) and (D) along with both identified PGB endmember compositions, HMD (orange) and RR (green). The grey horizontal band on plot (D) represents the ${ }^{143} \mathrm{Nd} /{ }^{144} \mathrm{Nd}$ ratio value for one of the RR group samples because $\mathrm{a}^{206} \mathrm{~Pb} /{ }^{204} \mathrm{~Pb}$ ratio value was not reported. Trace element and isotopic data from ${ }^{1}$ Wolff et al (2008) and ${ }^{2}$ this study. 

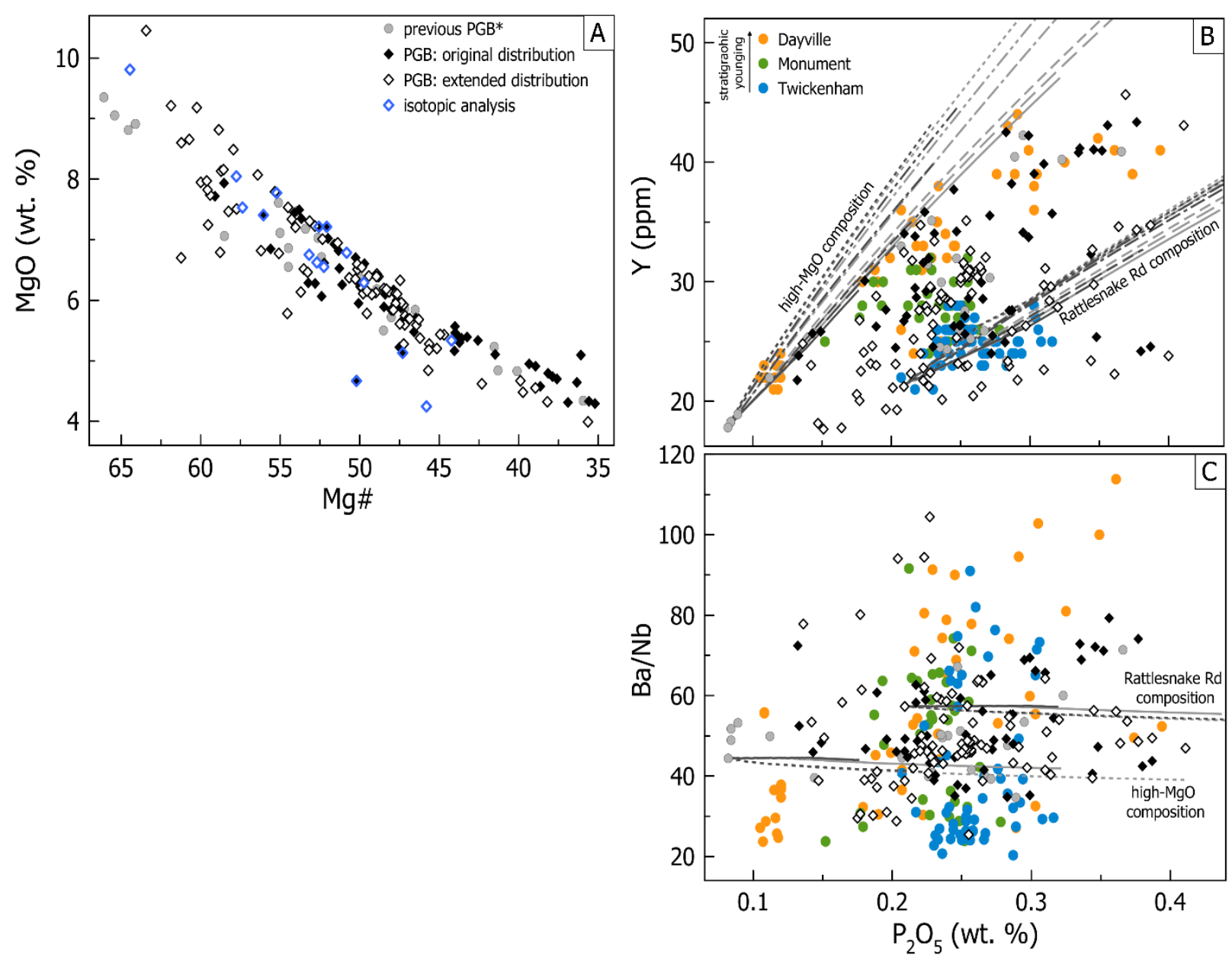

Figure 3.8 Geochemical comparison of PGB samples collected in this study relative to PGB subunits. (A) MgO (wt. \%) versus Mg\# for PGB samples. Blue diamond's illustrate which samples have $\mathrm{Sr}, \mathrm{Nd}, \mathrm{Hf}$, and $\mathrm{Pb}$ isotopic analyses. (B) $\mathrm{Y}$ (ppm) and (C) $\mathrm{Ba} / \mathrm{Nb}$ versus $\mathrm{P}_{2} \mathrm{O}_{5}$ (wt. \%) for $\mathrm{PGB}$ samples collected as part of this study compared to all previously analyzed PGB samples. Compositional evolution of both identified PGB primitive groups (HMD \& RR) shown using results of MELTS modelling. Dark grey lines represent modelling at 0.5 wt. $\% \mathrm{H}_{2} \mathrm{O}$ and light grey lines represent modelling at 0.1 wt. $\% \mathrm{H}_{2} \mathrm{O}$. Solid lines are $9 \mathrm{~kb}$ progressively more dashed to dotted lines, representing 2kb. PGB subunit geochemistry from Bailey $(1989 \mathrm{a}, \mathrm{b})$ and *previous PGB geochemistry from Wolff et al (2008). 

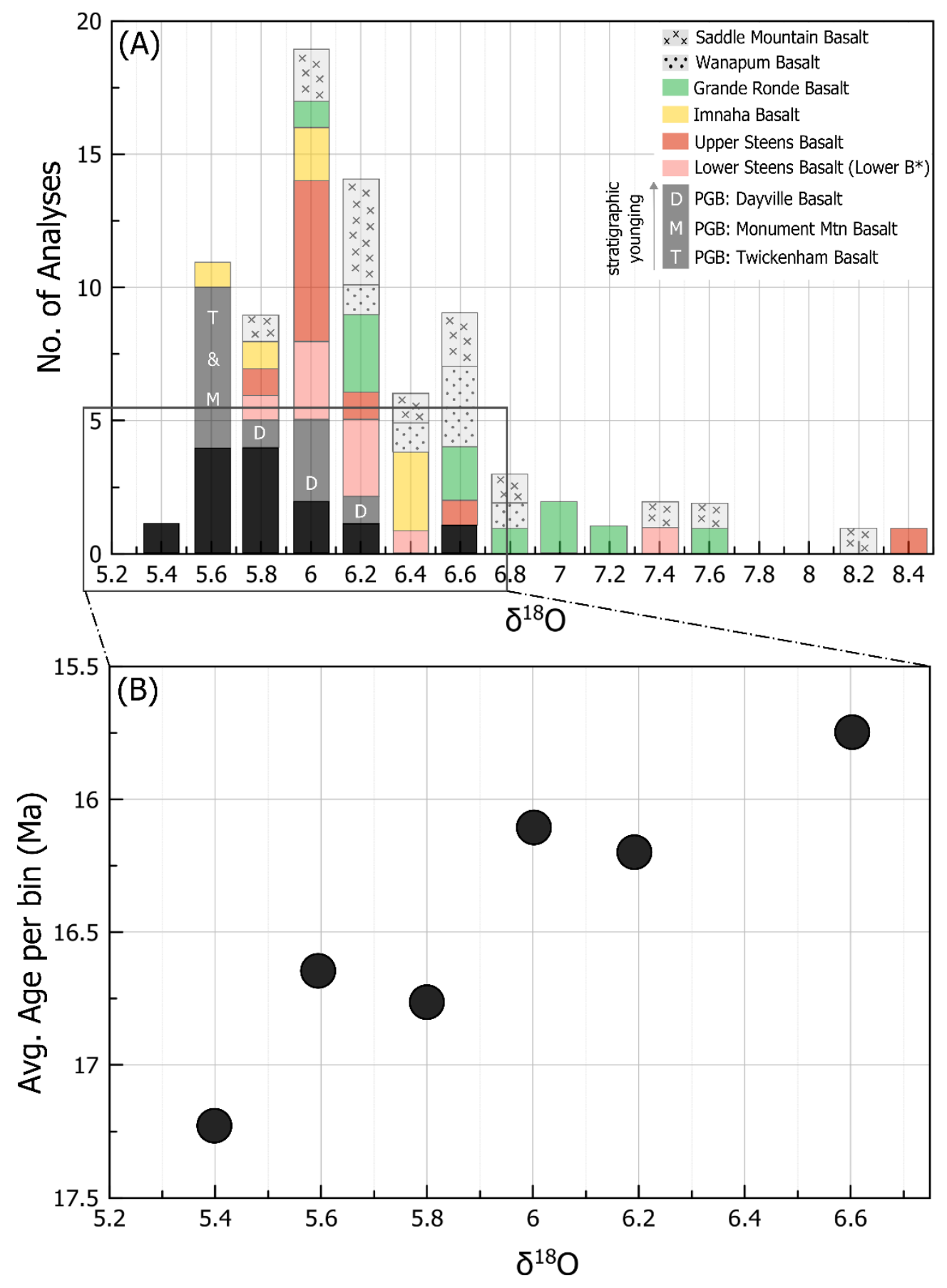

Figure 3.9 Histogram of $\delta^{18} \mathrm{O}$ compositions for PGB and other CRBG units. $\delta^{18} \mathrm{O}$ data compiled from Nelson, 1983; Carlson, 1984; Hooper and Swanson, 1990; Brandon et al. 1993, and Moore, 2018. Steens analyses are from plagioclase separates, and all other CRBG analyses are from whole-rock samples. 

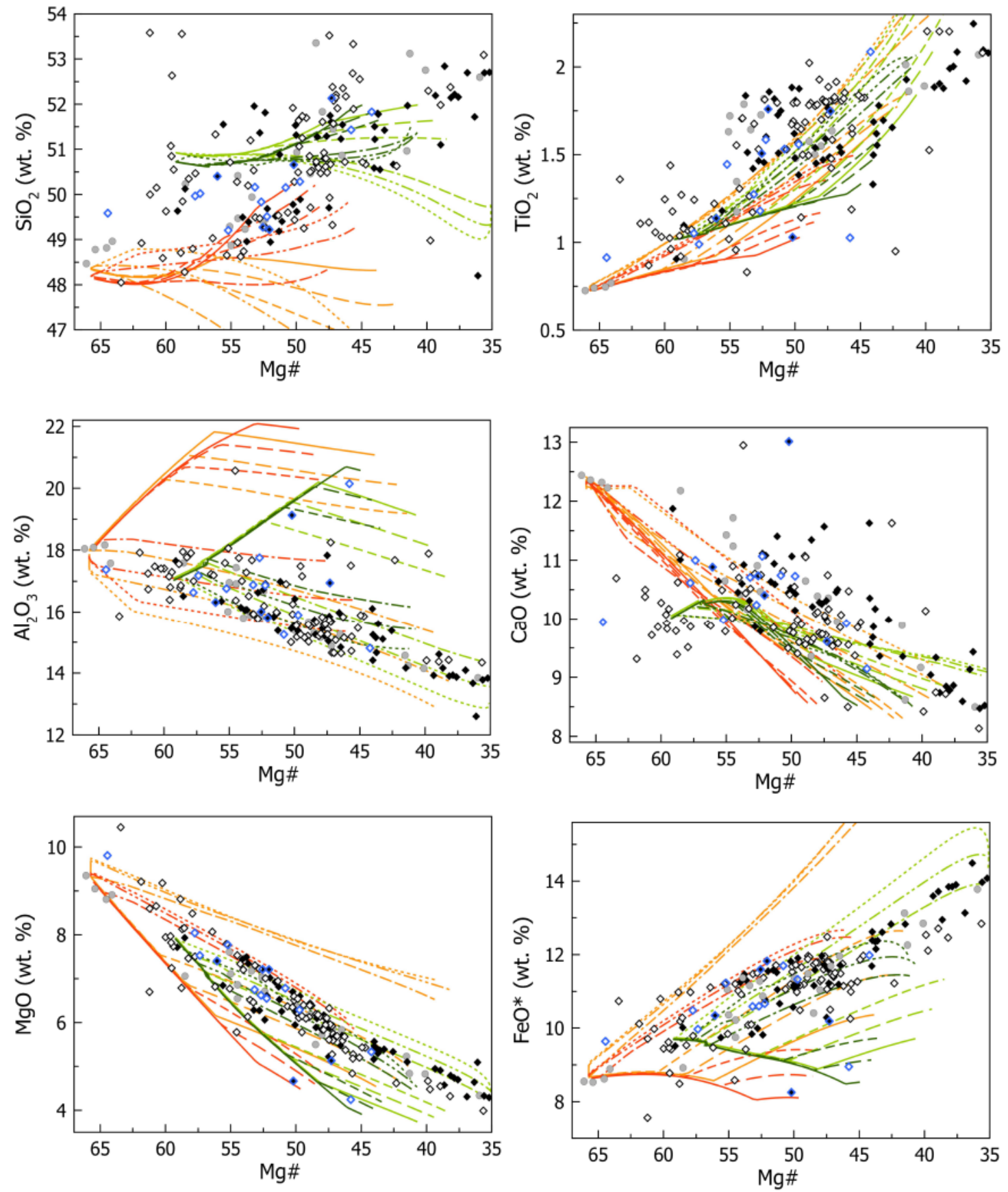

HMD Endmember (high MgO dikes)

$$
- \text { at } 0.1 \mathrm{H}_{2} \mathrm{O} \text { (wt.\%) }
$$

RR Endmember (Rattlesnake Rd lava)

- at $0.1 \mathrm{H}_{2} \mathrm{O}$ (wt.\%)

- at $0.5 \mathrm{H}_{2} \mathrm{O}$ (wt.\%)
Pressure (kb)

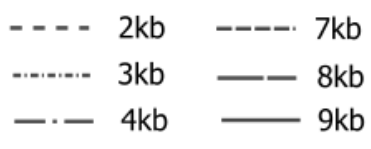

Samples

O PGB ${ }^{1}$

$\checkmark \mathrm{PGB}$, original distribution

$\diamond \mathrm{PGB}$, extended distribution

$\diamond$ samples with isotopic data 

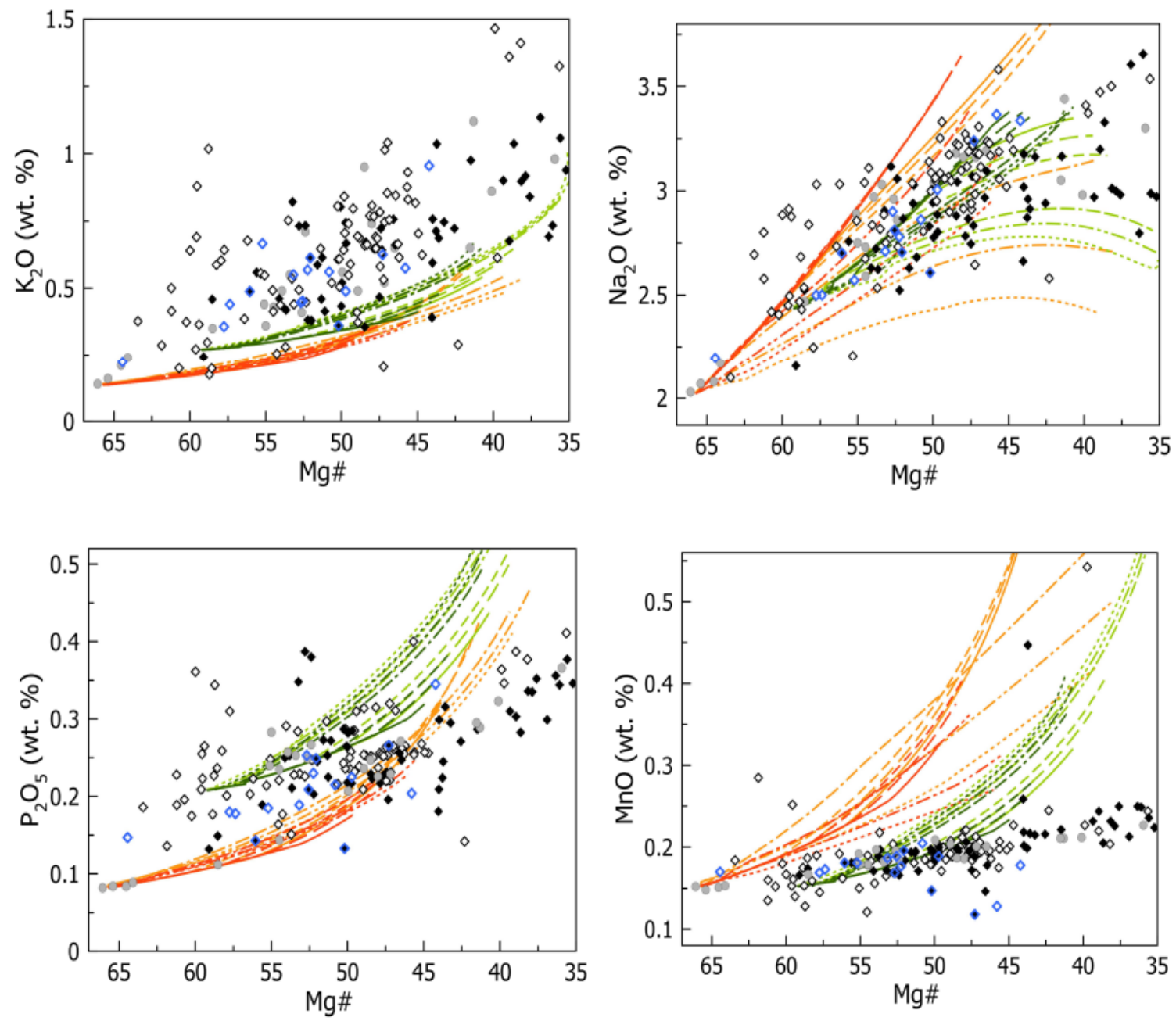

Figure 3.10 MELTS modelling results for major elements versus $\mathrm{Mg \#}$ for both $\mathrm{RR}$ and HMD primitive PGB endmember compositions. Models were conducted at low pressures of 2, 3, and $4 \mathrm{kbs}$ and high pressures of 7, 8 , and $9 \mathrm{kbs}$, and at both 0.1 and $0.5 \mathrm{wt} \% \% \mathrm{H}_{2} \mathrm{O}$. Blue diamonds illustrate which samples also have $\mathrm{Sr}, \mathrm{Nd}, \mathrm{Hf}$, and $\mathrm{Pb}$ isotopic analyses. 

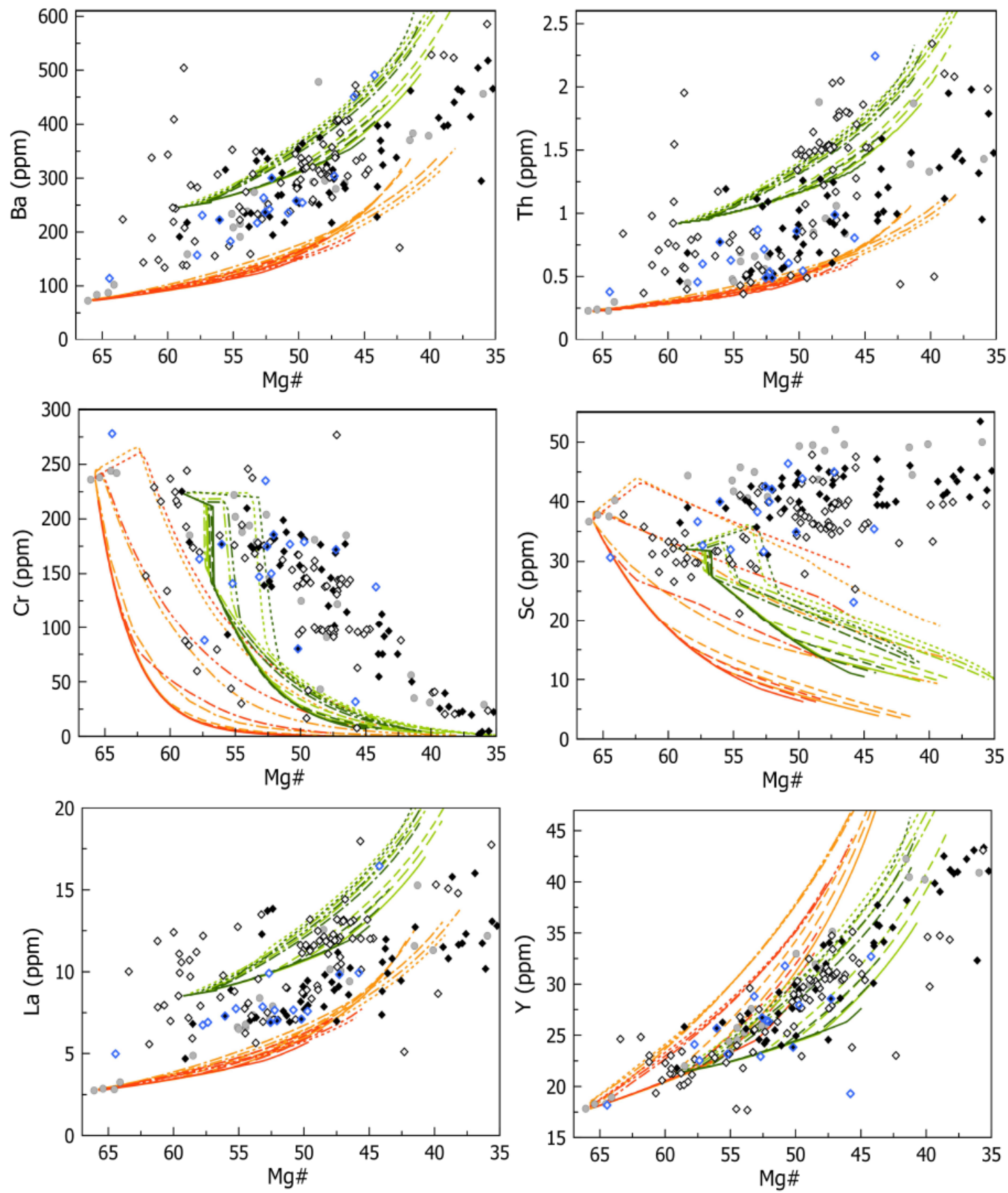

HMD Endmember (high MgO dikes)

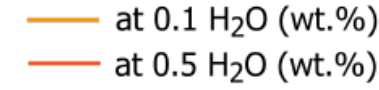

RR Endmember (Rattlesnake Rd lava)

- at $0.1 \mathrm{H}_{2} \mathrm{O}$ (wt.\%)

- at $0.5 \mathrm{H}_{2} \mathrm{O}$ (wt.\%)
Pressure (kb)

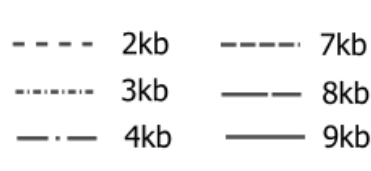

Samples

- PGB ${ }^{1}$

$\checkmark \mathrm{PGB}$, original distribution

$\diamond P G B$, extended distribution

$\diamond$ samples with isotopic data 

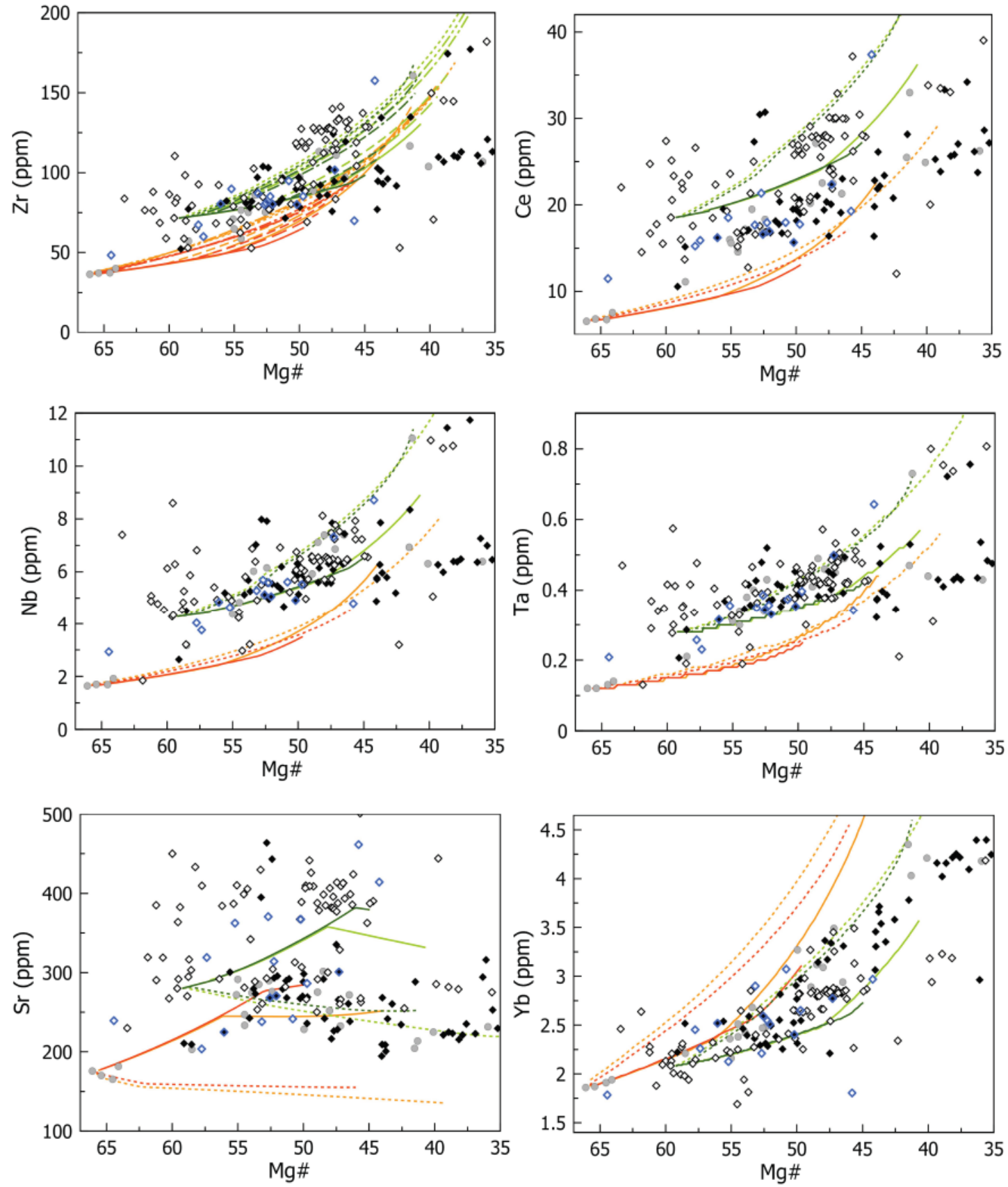

Figure 3.11 MELTS modelling results for selected trace elements versus Mg\# for both RR and HMD primitive PGB endmember compositions. Trace element concentrations were calculated using bulk partition coefficients and crystallizing phases predicted by MELTS for models run at low pressure $(2 \mathrm{~kb})$ and high pressure of $(9 \mathrm{~kb})$ at both 0.1 and $0.5 \mathrm{wt} . \% \mathrm{H}_{2} \mathrm{O}$. Blue diamonds illustrate which samples also have $\mathrm{Sr}, \mathrm{Nd}, \mathrm{Hf}$, and $\mathrm{Pb}$ isotopic analyses. 

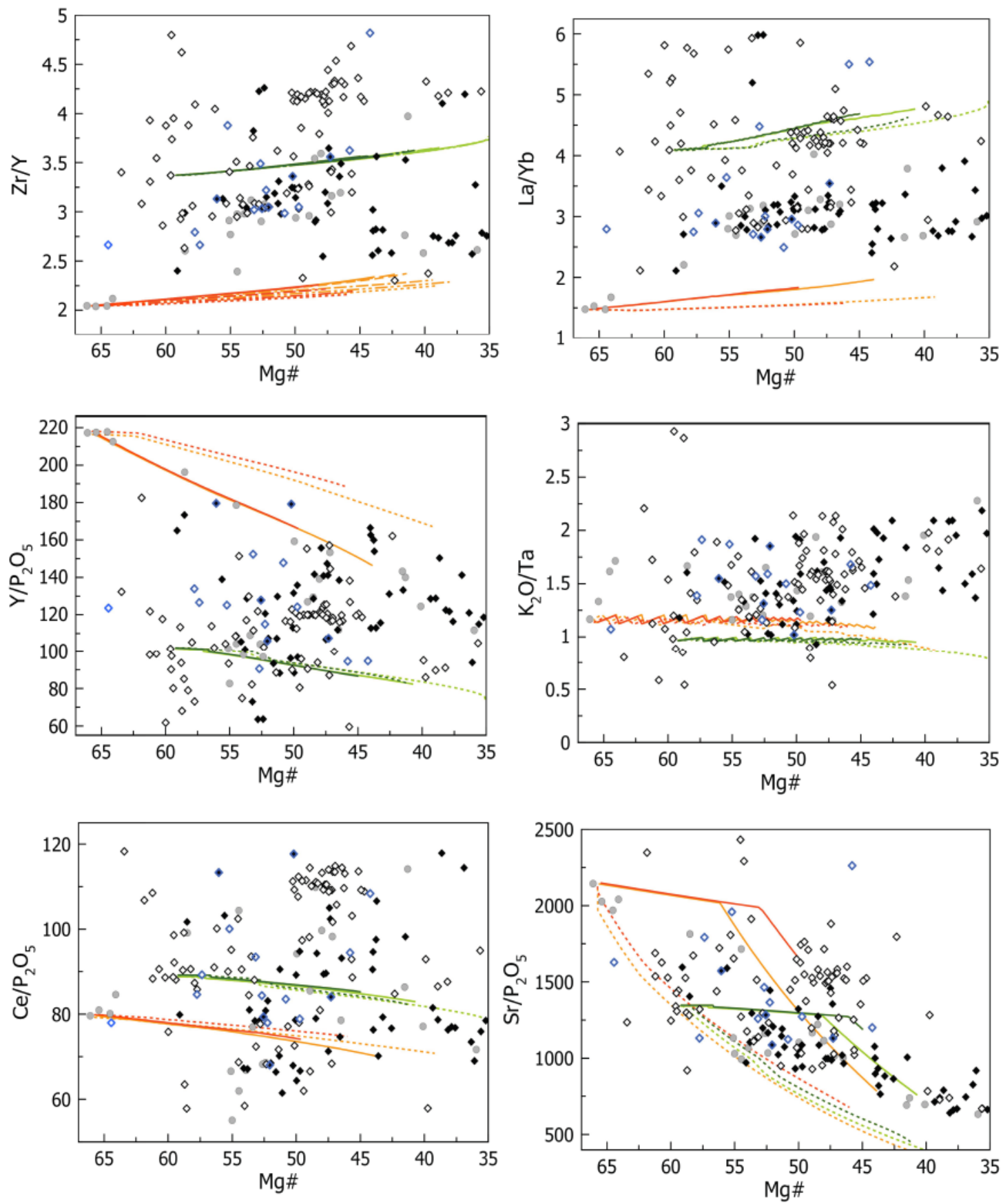

HMD Endmember (high MgO dikes)

$$
- \text { at } 0.1 \mathrm{H}_{2} \mathrm{O} \text { (wt.\%) }
$$

RR Endmember (Rattlesnake Rd lava)

- at $0.1 \mathrm{H}_{2} \mathrm{O}$ (wt.\%)

- at $0.5 \mathrm{H}_{2} \mathrm{O}$ (wt.\%)
Pressure (kb)

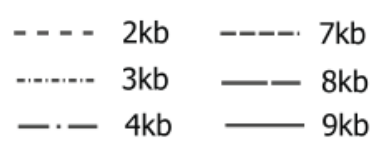

Samples

O PGB ${ }^{1}$

$\checkmark \mathrm{PGB}$, original distribution

$\diamond P G B$, extended distribution

$\diamond$ samples with isotopic data 

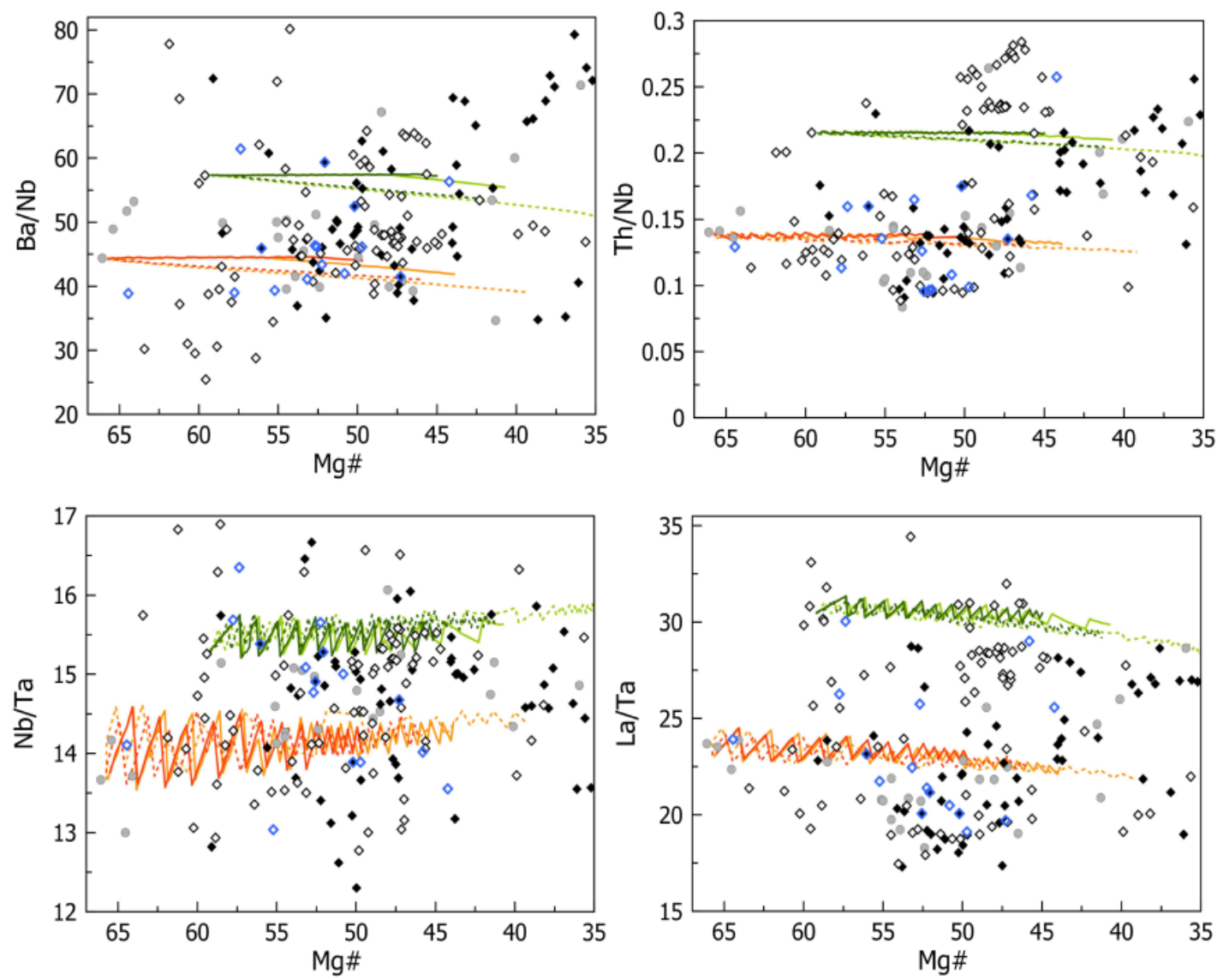

Figure 3.12 MELTS modelling results for major and trace element ratios versus $\mathrm{Mg \#}$ for both RR and HMD primitive PGB endmember compositions. Models were conducted at low pressures of 2, 3, and 4kbs and high pressures of 7, 8, and $9 \mathrm{kbs}$, and at both 0.1 and $0.5 \mathrm{wt} . \%$ $\mathrm{H}_{2} \mathrm{O}$. Blue diamonds illustrate which samples also have $\mathrm{Sr}, \mathrm{Nd}, \mathrm{Hf}$, and $\mathrm{Pb}$ isotopic analyses. 


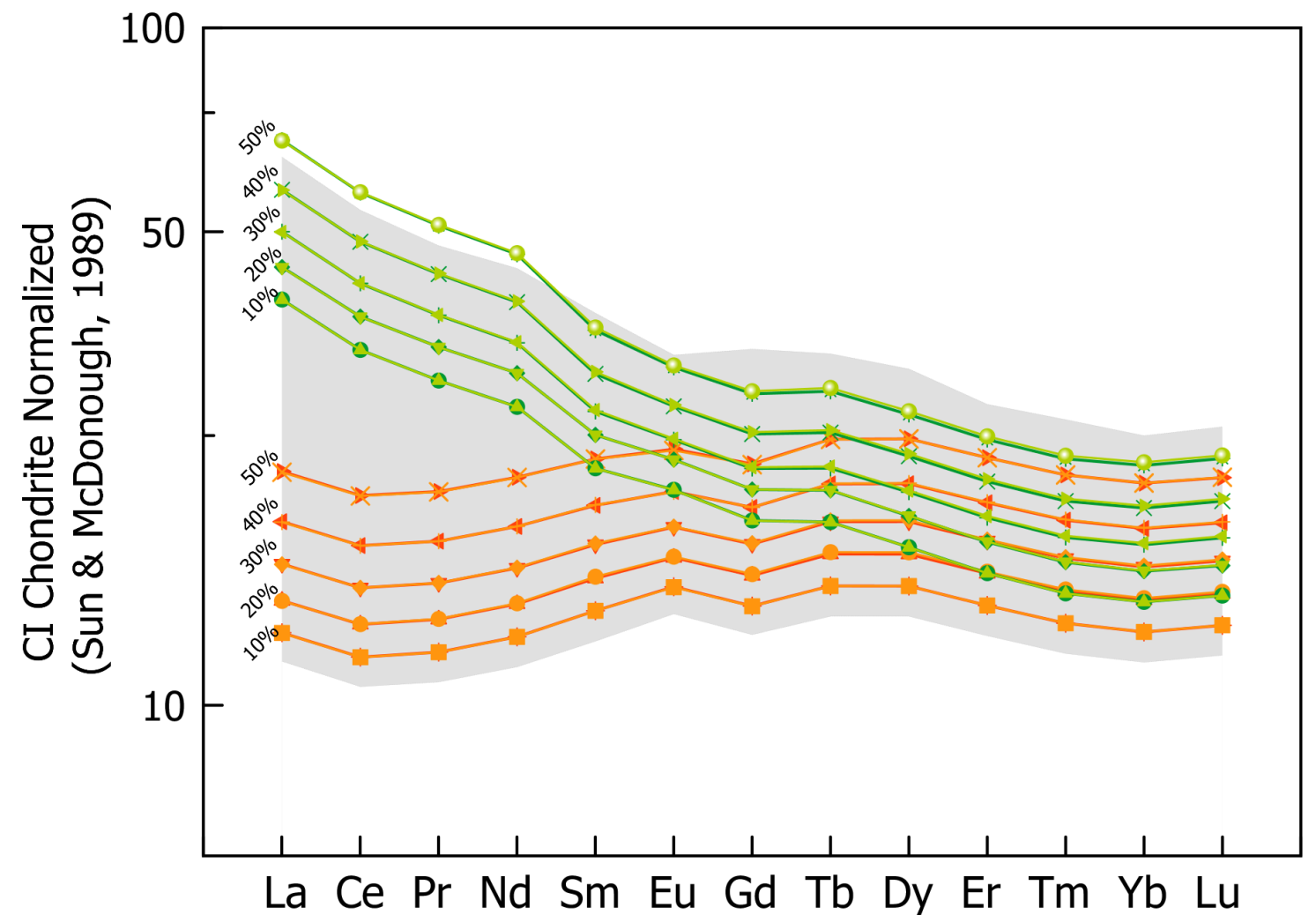

Figure 3.13 CI-Chondrite -normalized rare earth element diagram with compositional models for 10, 20, 30, 40, and 50\% fractionation in the HMD and RR endmember compositions. Bulk partition coefficients calculated using predicted modal abundances of crystallizing phases at each fractionation amount in MELTS. Grey field represents previous PGB compositional range from Wolff et al (2008). 


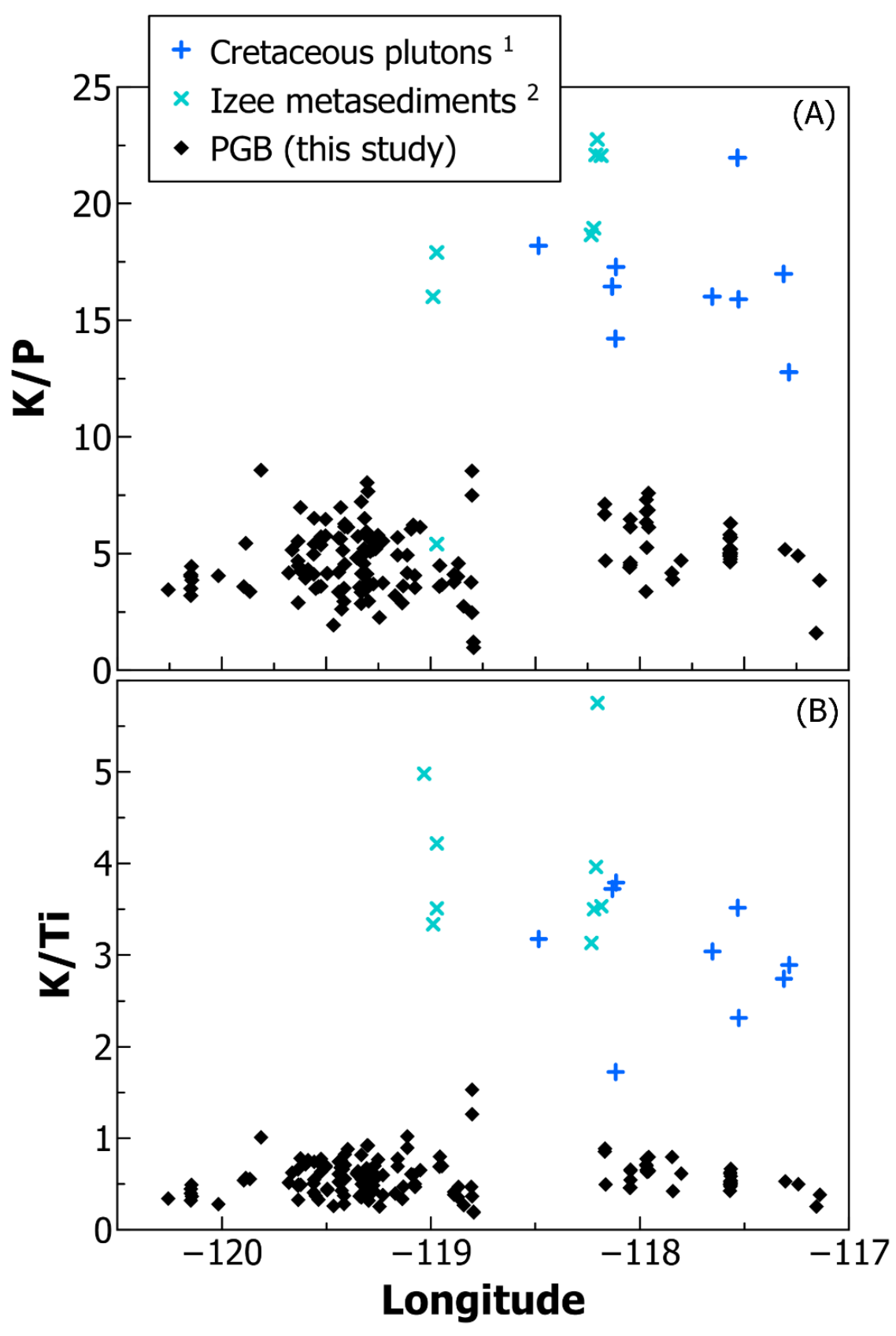

Figure 3.14 Trace element ratios (A) K/Ti and (B) K/P versus longitude for PGB samples (this study). Both ratios are sensitive to assimilation when the crustal contaminant is granitic, and may indicate if contamination influences geochemical signatures of the PGB.

${ }^{1}$ Cretaceous plutons include the Lookout Mountain, Turemen Ranch, Amelia, and Pedro Mountain pluton (data from Gashnig et al., 2017; Standhaft, 2018). ${ }^{2}$ Samples of Izee metasediments, predominantly argillite and shale lithologies (data from Streck, unpub.). 


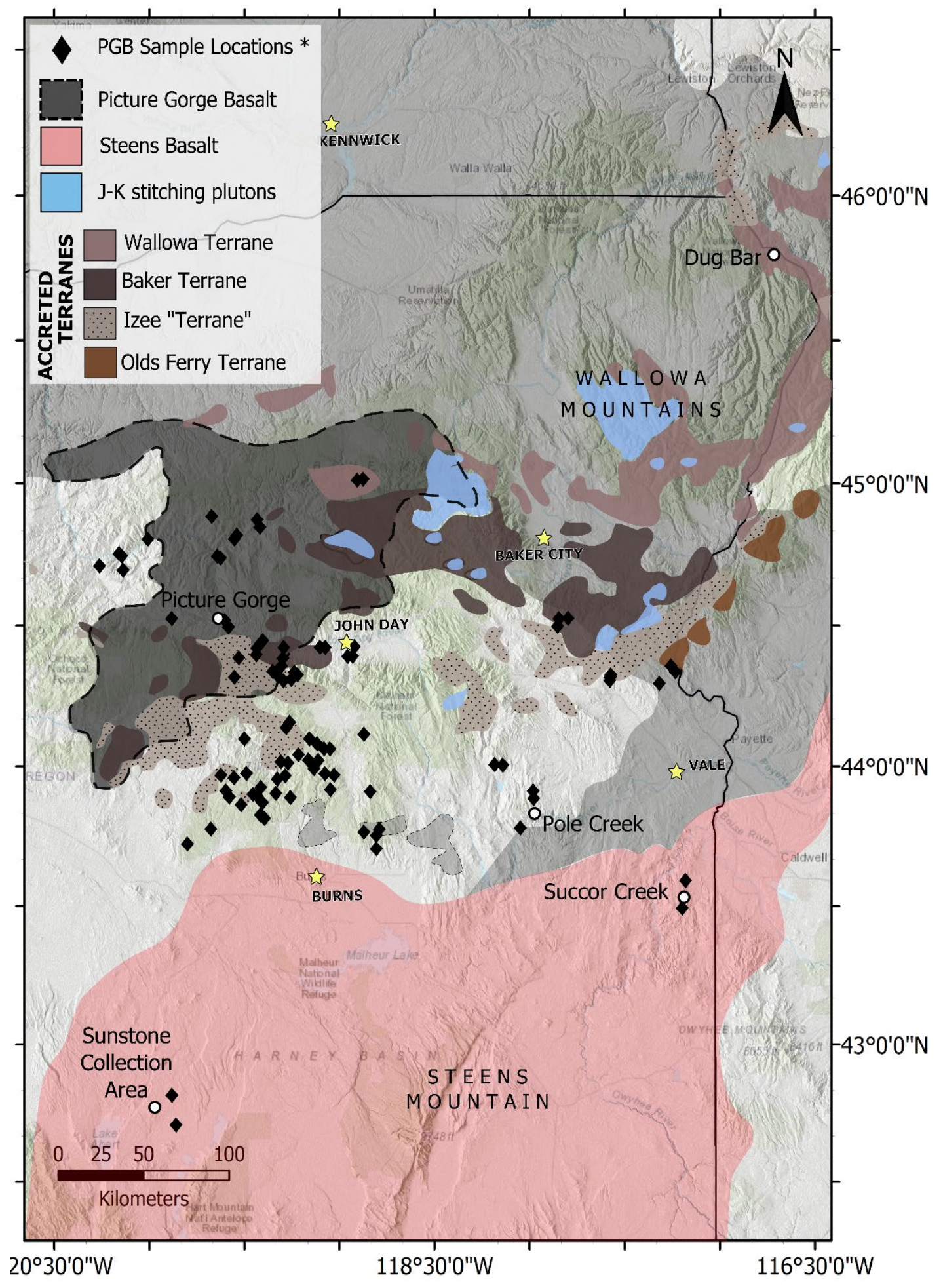

Figure 3.15 Spatial extent of accreted terranes throughout the Blue Mountains Province in eastern Oregon. The spatial extent of PGB is predominately within rocks of the Izee tectonostratigraphic unit. Locations of terranes modified from Schwartz et al., 2011. 


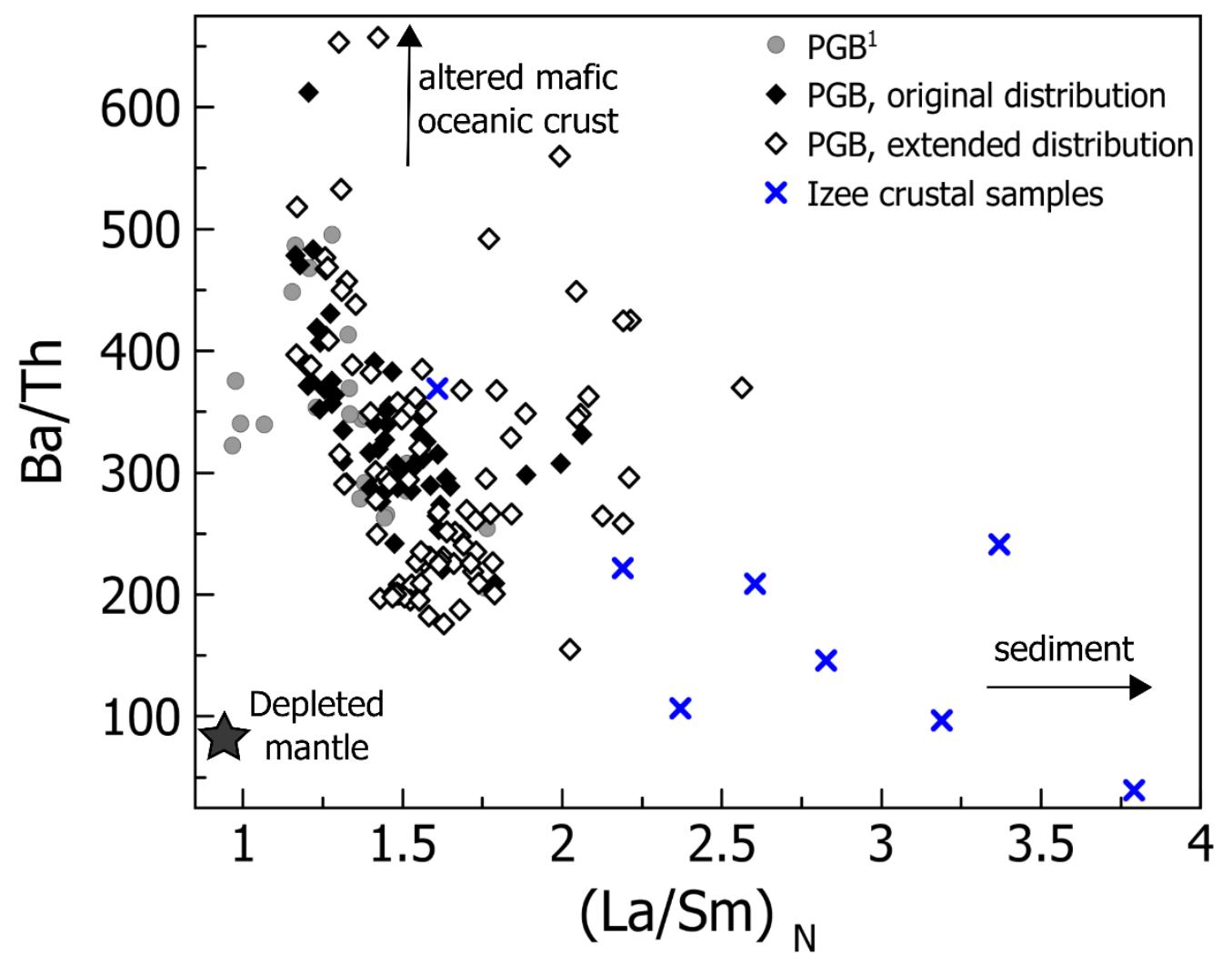

Figure 3.16 $\mathrm{Ba} / \mathrm{Th}$ versus $\mathrm{La} / \mathrm{Sm}$ normalized of PGB and Izee metasediments. Izee analyses from Streck, unpublished data. 

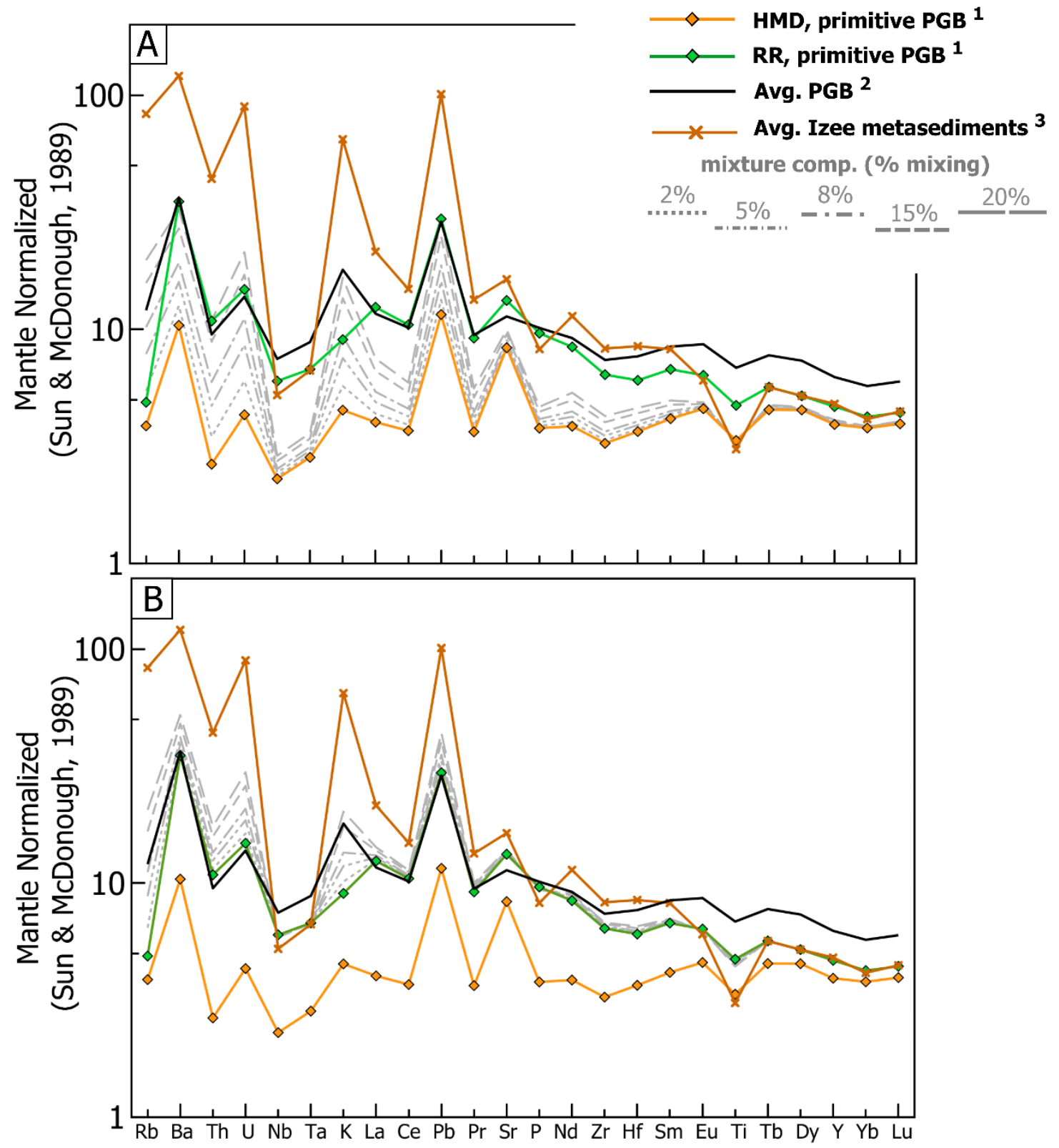

Figure 3.17 Mixing models highlighting mixture compositions (m) resulting from 2, 5, 8, 15, and $20 \%$ contamination with average Izee metasediments on mantle normalized trace element diagrams. Initial compositions were modeled as (A) the primitive HMD endmember, and (B) the primitive RR endmember. Geochemical compositions for average PGB and Izee metasedimentary material shown for reference, data compiled from ${ }^{1}$ this study; ${ }^{2}$ Wolff et al., 2008; and ${ }^{3}$ Streck, unpublished data. 

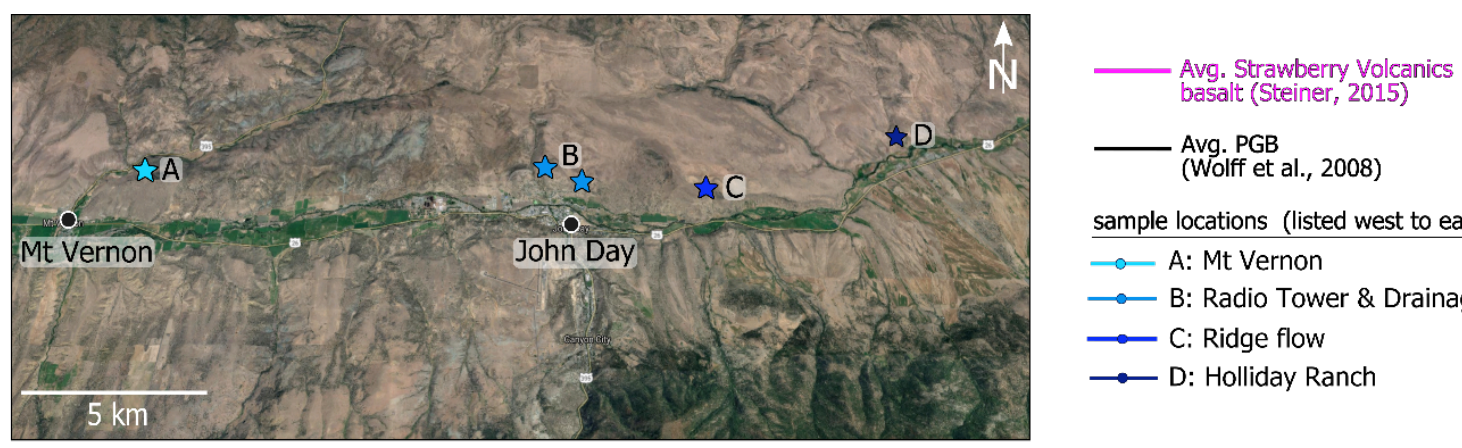

sample locations (listed west to east)

- A: Mt Vernon

$\longrightarrow$ B: Radio Tower \& Drainage

$\longrightarrow$ C: Ridge flow

$\longrightarrow$ D: Holliday Ranch
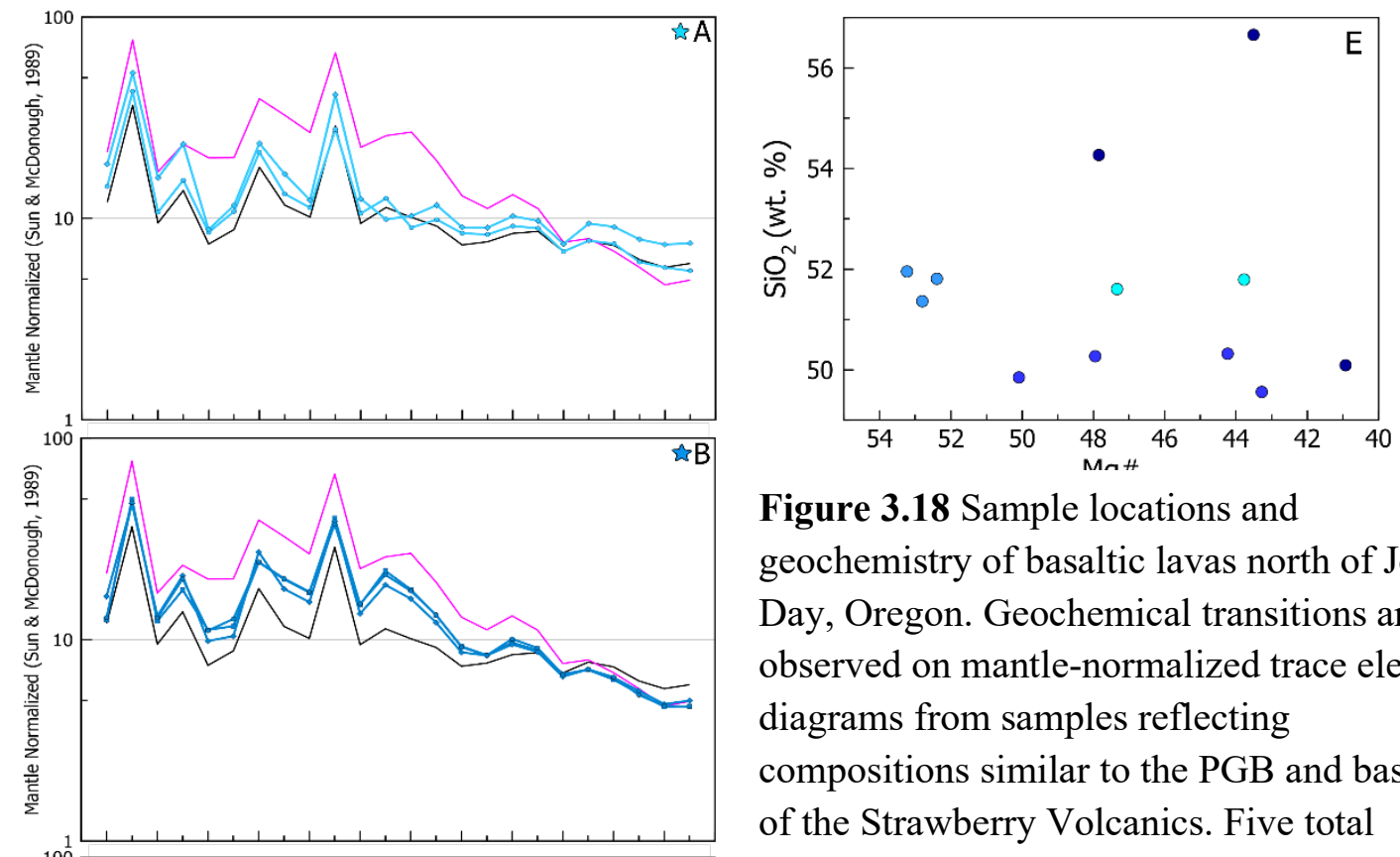

Figure 3.18 Sample locations and geochemistry of basaltic lavas north of John Day, Oregon. Geochemical transitions are observed on mantle-normalized trace element diagrams from samples reflecting compositions similar to the PGB and basalts of the Strawberry Volcanics. Five total sample locations are included, two are shown together in location B as they are in close spatial proximity. Moving west to east: samples at location include (A) two lava flows at the top of Mt. Vernon and compositionally reflect lavas of PGB, (B) two lava flows at the top of a radio tower, (C) another lava flow in a small drainage to the east, and (D) lavas exposed near Holliday Ranch and basaltic lavas here are compositionally variable. These lavas were sampled above the Dinner Creek Tuff unit 2, dated at 15.6 Ma (Streck et al., 2015). (E) $\mathrm{SiO}_{2}$ (wt. \%) versus $\mathrm{Mg} \#$ to evaluate if enrichment is a function of magmatic evolution. 

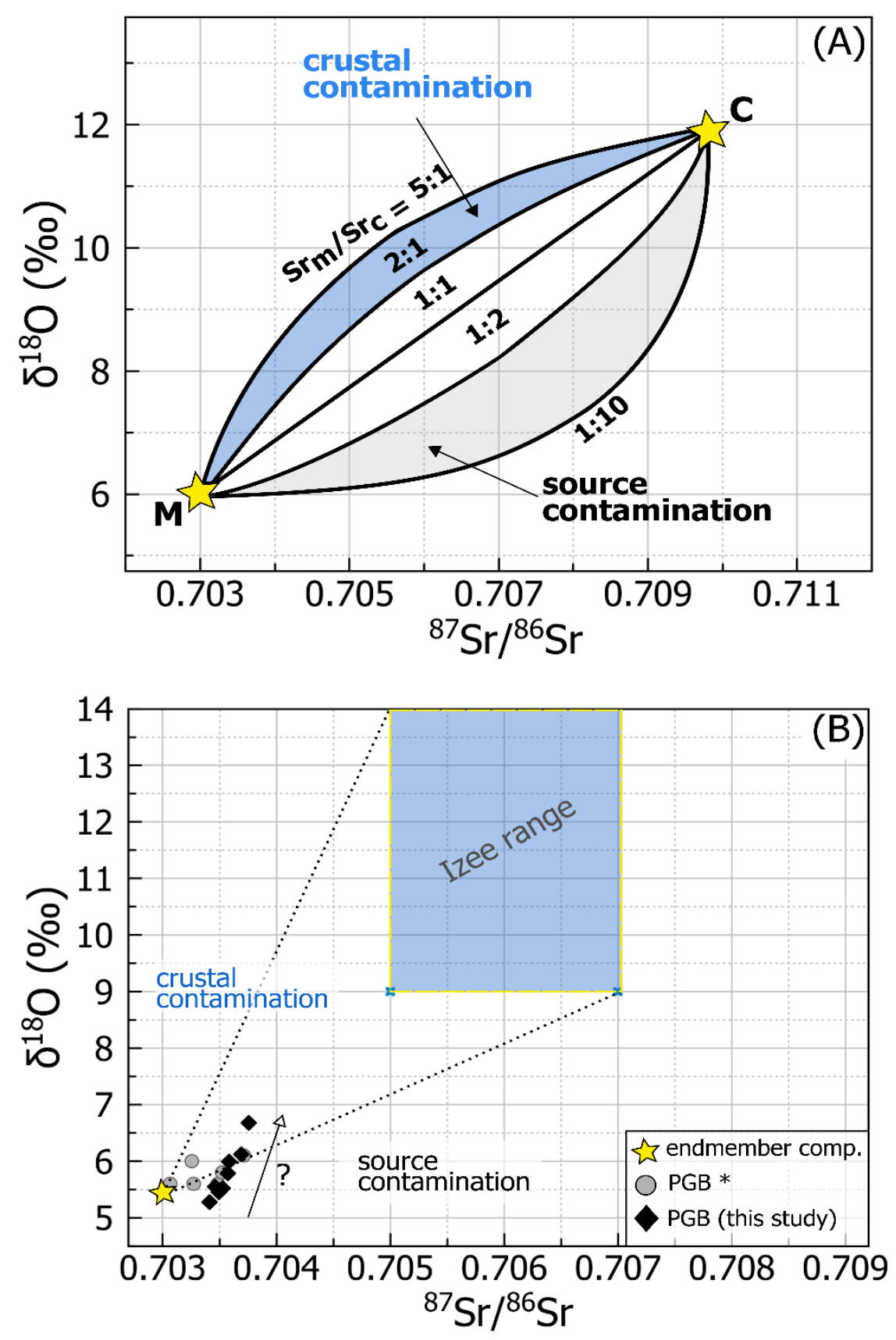

Figure 3.19 (A) Mixing curves of $\delta^{18} \mathrm{O}$ versus ${ }^{87} \mathrm{Sr} /{ }^{86} \mathrm{Sr}$ ratios for two hypothetical endmembers, $\mathrm{M}$ (mantle) and C (crustal). Modified from James, 1981. (B) Plot of $\delta^{18} \mathrm{O}$ versus ${ }^{87} \mathrm{Sr} /{ }^{86} \mathrm{Sr}$ ratios for PGB samples and approximated Izee crustal material as a potential contaminant. Mixing lines are not included as there is not a well-defined isotopic composition for this potential contaminant. * Data from Wolff et al (2008). 

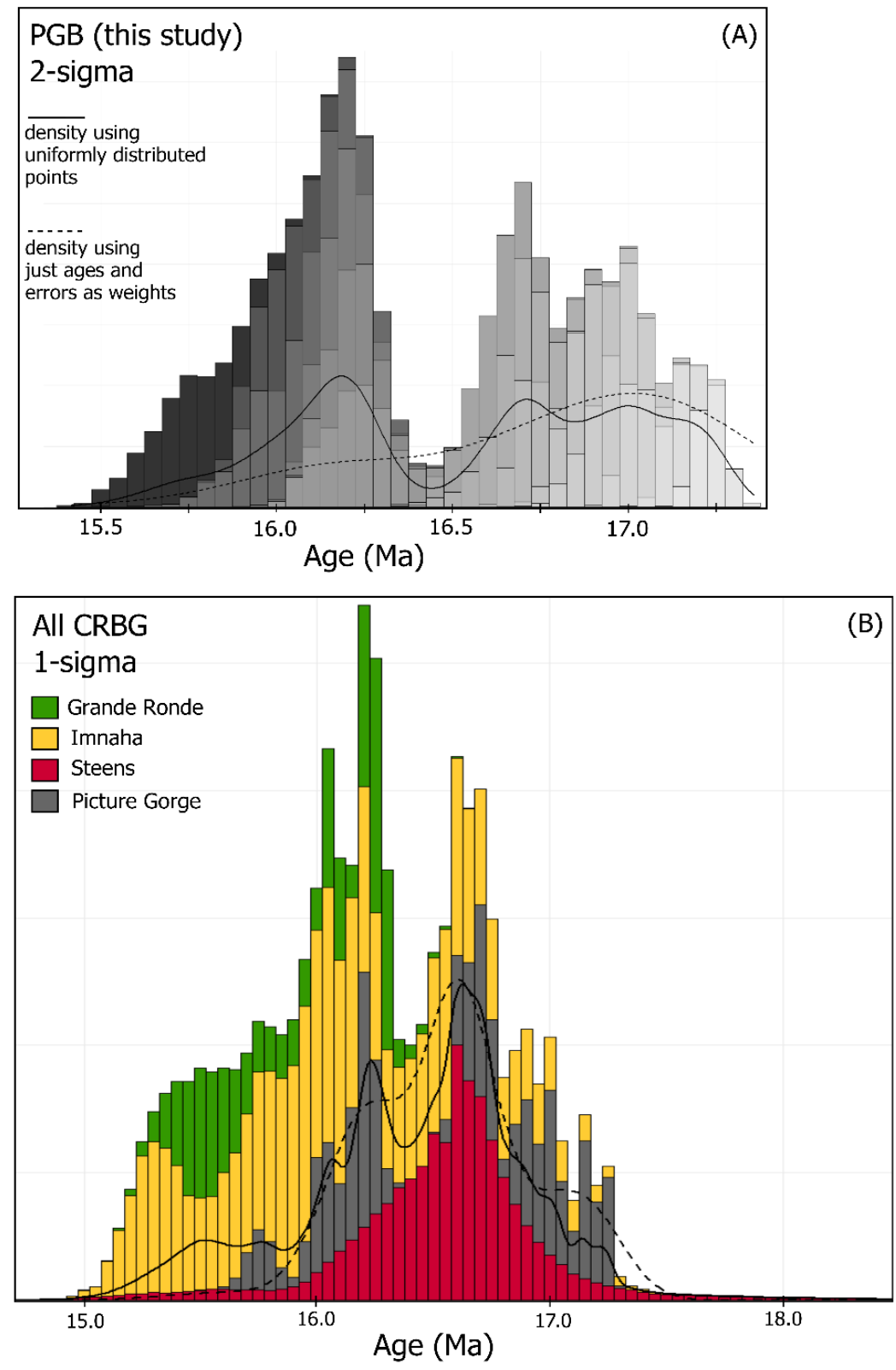

Figure 3.20 Histogram of all published CRBG ages illustrating two temporal pulses of volcanism. (A) PGB histogram of each age at 2-sigma using 1000 uniformly distributed points. (B) CRBG histogram of each age at 1-sigma using 4000 uniformly distributed points. Ages are binned as $0.05 \mathrm{Ma}$ and only included ages calculated with a ${ }^{40} \mathrm{~K}$ decay constant of $5.463 \times 10^{-10} / \mathrm{a}$ (Min et al., 2000) and FCT age of 28.201 Ma (Kuiper et al., 2008). Ages are compiled from the following studies listed in chronological order: Baksi \& Watkins, 1973; Watkins \& Baksi, 1974; Baksi, 1974; Long \& Duncan, 1983; Baksi, 1989; Hooper et al., 2002; Brueske et al., 2007; Brueseke \& Hart, 2008; Jarboe et al., 2010; Barry et al., 2010; Baksi, 2013; Barry et al., 2013; Camp et al., 2013; Wolff \& Ramos, 2013; Mahood \& Benson, 2017; Moore, 2018; Kasbohm \& Schoene, 2018; and Cahoon et al., 2020. 

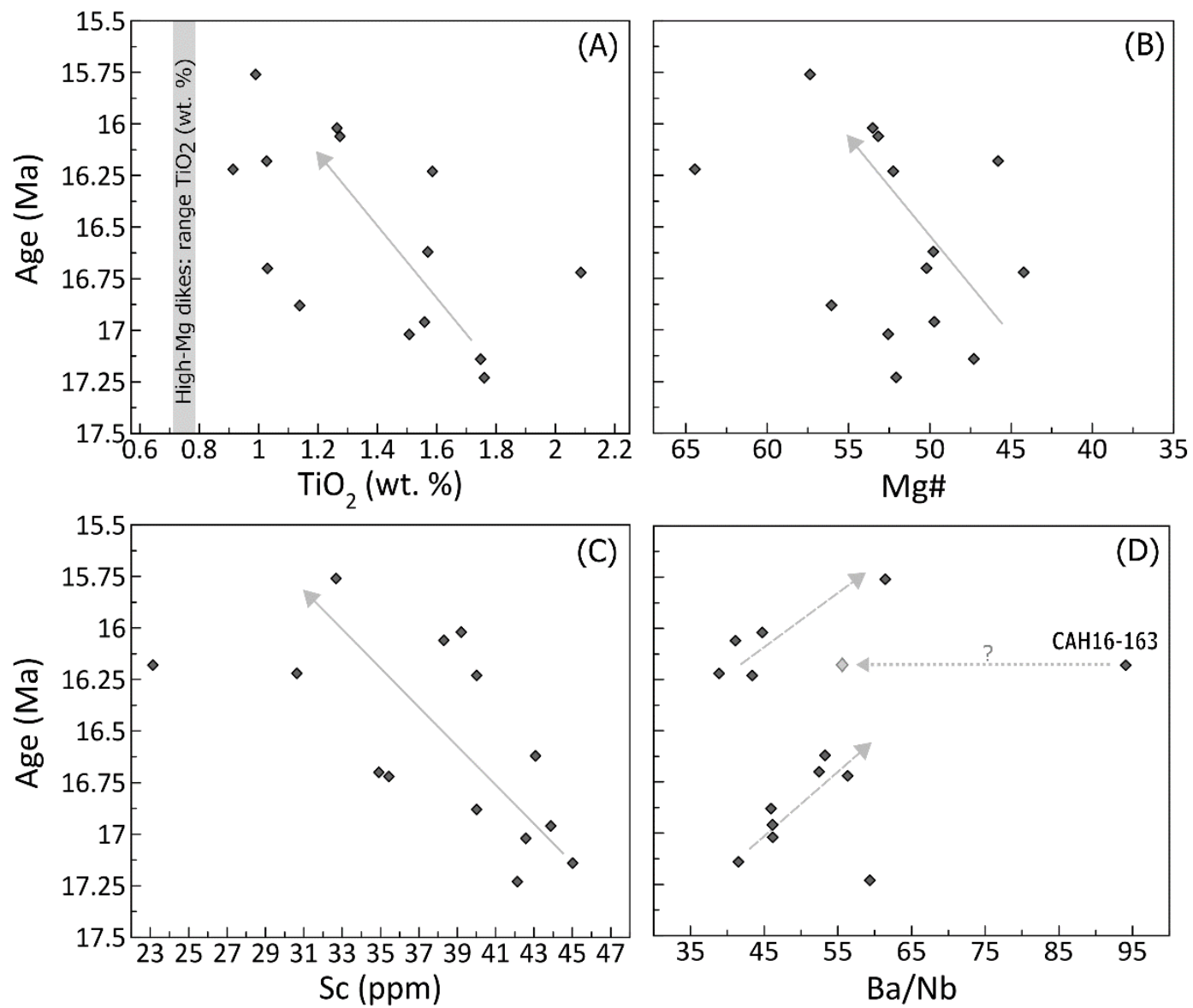

Figure 3.21 Geochemical trends with time for dated PGB samples in this study. PGB sample ages (Ma) versus (A) $\mathrm{TiO}_{2}$ (wt. \%), the grey bar represents the range of $\mathrm{TiO}_{2}$ (wt. $\%)$ values for the high- $\mathrm{MgO}$ dikes as no age data is available. Age (Ma) versus (B) Mg\#, (C) $\mathrm{Sc}(\mathrm{ppm}),(\mathrm{D}) \mathrm{Ba} / \mathrm{Nb}$, and (E) ${ }^{143} \mathrm{Nd} /{ }^{144} \mathrm{Nd}$ isotopic ratios.

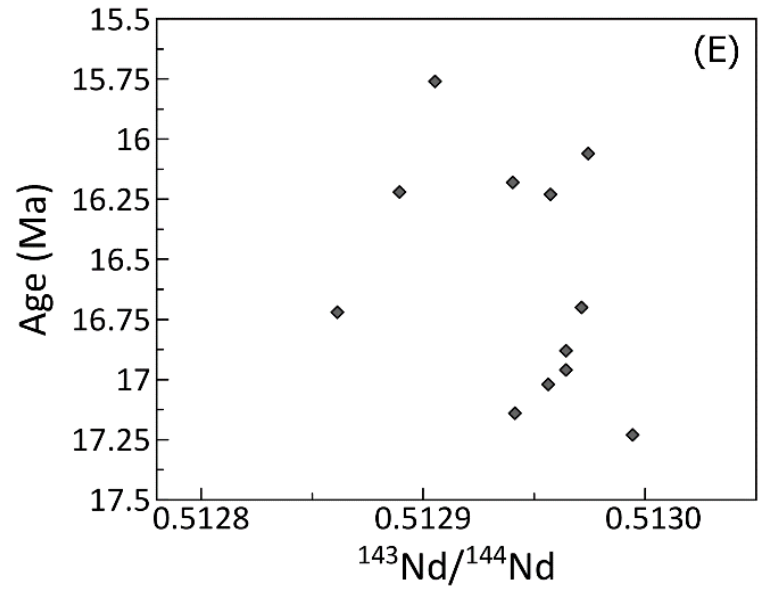

(D) Dated sample $\mathrm{CAH16-163}$ contains $\mathrm{Ba} / \mathrm{Nb}>90$. However, two other samples from the same lava flow (samples CAH17-217 and CAH17-218, Appendix A) contain lower $\mathrm{Ba} / \mathrm{Nb}$ ratios approximately $\sim 54-58$, represented by the light grey diamond. If this lower $\mathrm{Ba} / \mathrm{Nb}$ value for sample $\mathrm{CAH16-163}$ is substituted, it appears $\mathrm{Ba} / \mathrm{Nb}$ values increase within each discrete pulse of PGB volcanic activity. 


\section{REFERENCES}

Bailey, M.M., 1989, Evidence for magma recharge and assimilation in the Picture Gorge basalt subgroup, Columbia River basalt group. Volcanism and tectonism in the Columbia River flood-basalt province: Geological Society of America Special Paper, 239, pp.343-355.

Baksi, A.K. and Watkins, N.D., 1973, Volcanic production rates: comparison of oceanic ridges, islands, and the Columbia Plateau basalts: Science, v. 180, p. 493-496.

Baksi, A.K., 2013, Timing and duration of volcanism in the Columbia River Basalt Group: A review of existing radiometric data and new constraints on the age of the Steens through Wanapum Basalt extrusion, in Geological Society of America Special Paper, 497, p. 67-85.

Barry, T.L., Self, S., Kelley, S.P., Reidel, S., Hooper, P. and Widdowson, M., 2010, New 40Ar/39Ar dating of the Grande Ronde lavas, Columbia River Basalts, USA: Implications for duration of flood basalt eruption episodes. Lithos, v. 118, p. 213222.

Barry, T.L., Kelley, S.P., Reidel, S.P., Camp, V.E., Self, S., Jarboe, N.A., Duncan, R.A., Renne, P.R., Ross, M.E., Wolff, J.A. and Martin, B.S., 2013, Eruption chronology of the Columbia River Basalt Group, in The Columbia River Flood Basalt Province: Geological Society of America Special Paper, 497, p. 45-66.

Bindeman, I., 2008. Oxygen isotopes in mantle and crustal magmas as revealed by single crystal analysis. Reviews in Mineralogy and Geochemistry, 69(1), pp.445-478.

Bond, J.G., 1963, Geology of the Clearwater embayment: Idaho Bureau of Mines and Geology: Pamphlet 128, 83 p. 
Brandon, A.D. and Goles, G.G., 1988, A Miocene subcontinental plume in the Pacific Northwest: Geochemical evidence. Earth and Planetary Science Letters, v. 88, p. 273-283.

Brown, C.E. and Thayer, T.P., 1966, Geologic map of the Canyon City quadrangle, northeastern Oregon: U.S. Geological Survey, scale 1:250 000, 1 sheet.

Camp, V.E., 1995, Mid-Miocene propagation of the Yellowstone mantle plume head beneath the Columbia River basalt source region: Geology, v. 23, p. 435-438.

Camp, V.E., 2013, Origin of Columbia River Basalt: Passive rise of shallow mantle, or active upwelling of a deep-mantle plume, in Geological Society of America Special Paper, 497, p. 181-199.

Camp, V.E., Ross, M.E. and Hanson, W.E., 2003, Genesis of flood basalts and Basin and Range volcanic rocks from Steens Mountain to the Malheur River Gorge, Oregon: Geological Society of America Bulletin, v. 115, p. 105-128.

Camp, V.E. and Ross, M.E., 2004, Mantle dynamics and genesis of mafic magmatism in the intermontane Pacific Northwest: Journal of Geophysical Research: Solid Earth, v. 109, B08204, doi:10.1029/2003JB002838.

Camp, V.E. and Hanan, B.B., 2008, A plume-triggered delamination origin for the Columbia River Basalt Group: Geosphere, v. 4, p. 480-495.

Camp, V.E., Ross, M.E., Duncan, R.A., Jarboe, N.A., Coe, R.S., Hanan, B.B. and Johnson, J.A., 2013, The Steens basalt: Earliest lavas of the Columbia River basalt group, in Geological Society of America Special Paper, 497, p. 87-116.

Camp, V.E., Reidel, S.P., Ross, M.E., Brown, R.J. and Self, S., 2017, Field-trip guide to the vents, dikes, stratigraphy, and structure of the Columbia River Basalt Group, 
eastern Oregon and southeastern Washington, in Field-trip guides to selected volcanoes and volcanic landscapes of the western United States, Scientific Investigations Report 2017-5022-N.

Campbell, I.H. and Davies, G.F., 2006, Do mantle plumes exist? Episodes, 29(3), p.162.

Carlson, R.W., 1984, Isotopic constraints on Columbia River flood basalt genesis and the nature of the subcontinental mantle. Geochimica et Cosmochimica Acta, v. 48, p. 2357-2372.

Carlson, R.W., Lugmair, G.W. and Macdougall, J.D., 1981. Columbia River volcanism: the question of mantle heterogeneity or crustal contamination. Geochimica et Cosmochimica Acta, 45(12), pp.2483-2499.

Coffin, M.F., and Eldholm, O., 1994, Large igneous provinces: Crustal structure, dimensions, and external consequences: Reviews of Geophysics, v. 32, p. 1-36.

_2005, Large igneous provinces, in Selley, R.C., Cocks, R., and Plimer, I.R. eds. Encyclopedia of Geology: Oxford, Elsevier, p. 315-323.

Cruz, M., 2017, Field Mapping Investigation and Geochemical Analysis of Volcanic Units within the Dinner Creek Tuff Eruptive Center, Malheur County, Eastern Oregon [Master's Thesis]: Portland State University, 217 p.

Dickinson, W.R., 1979. Mesozoic forearc basin in central Oregon. Geology, 7(4), pp.166170.

Dickinson, W.R. and Thayer, T.P., 1978. Paleogeographic and paleotectonic implications of Mesozoic stratigraphy and structure in the John Day inlier of central Oregon. 
Dorsey, R.J. and LaMaskin, T.A., 2007, Stratigraphic record of Triassic-Jurassic collisional tectonics in the Blue Mountains province, northeastern Oregon. American Journal of Science, 307(10), pp.1167-1193.

Ernst, R. E. and Buchan, K. L., 1997, Giant radiating dyke swarms: Their use in identifying pre-Mesozoic large igneous provinces and mantle plumes. Geophys. Monograph 100, 297-333.

Ernst, R.E., Buchan, K.L. and Campbell, I.H., 2005, Frontiers in large igneous province research. Lithos, 79(3-4), pp.271-297.

Ernst, R.E., Liikane, D.A., Jowitt, S.M., Buchan, K.L. and Blanchard, J.A., 2019, A new plumbing system framework for mantle plume-related continental Large Igneous Provinces and their mafic-ultramafic intrusions. Journal of Volcanology and Geothermal Research, 384, pp.75-84.

Feakins, S.J., Warny, S. and Lee, J.E., 2012, Hydrologic cycling over Antarctica during the middle Miocene warming. Nature Geoscience, v. 1, p. 557.

Fiebelkorn, R.B., Walker, G.W., MacLeod, N.S., McKee, E.H. and Smith, J.G., 1982, Index of K-Ar Age Determinations for the State of Oregon: U.S. Geological Survey Open-File Report 82-596.

Fruchter, J.S. and Baldwin, S.F., 1975, Correlations between dikes of the Monument swarm, central Oregon, and Picture Gorge Basalt flows: Geological Society of America Bulletin, v. 86, p. 514-516.

Garçon, M., Boyet, M., Carlson, R.W., Horan, M.F., Auclair, D. and Mock, T.D., 2018. Factors influencing the precision and accuracy of Nd isotope measurements by thermal ionization mass spectrometry. Chemical Geology, 476, pp.493-514. 
Gaschnig, R.M., Macho, A.S., Fayon, A., Schmitz, M., Ware, B.D., Vervoort, J.D., Kelso, P., LaMaskin, T.A., Kahn, M.J. and Tikoff, B., 2017, Intrusive and depositional constraints on the Cretaceous tectonic history of the southern Blue Mountains, eastern Oregon. Lithosphere, 9(2), pp.265-282.

Geist, D. and Richards, M., 1993, Origin of the Columbia Plateau and Snake River plain: Deflection of the Yellowstone plume: Geology, v.21, p. 789-792.

Glen, J.M. and Ponce, D.A., 2002, Large-scale fractures related to inception of the Yellowstone hotspot: Geology, v. 30, p. 647-650.

Greene, R.C., Walker, G.W. and Corcoran, R.E., 1972, Geologic map of the Burns quadrangle, Oregon: U.S. Geological Survey, scale 1:250 000, 1 sheet. (No. 680).

Griffiths, R.W. and Campbell, I.H., 1991, Interaction of mantle plume heads with the Earth's surface and onset of small-scale convection. Journal of Geophysical Research: Solid Earth, 96(B11), pp.18295-18310.

Hales, T.C., Abt, D.L., Humphreys, E.D. and Roering, J.J., 2005, A lithospheric instability origin for Columbia River flood basalts and Wallowa Mountains uplift in northeast Oregon. Nature, 438(7069), pp.842-845.

Hill, R.I., Campbell, I.H., Davies, G.F., and Griffiths, R.W., 1992, Mantle plumes and continental tectonics: Science, v. 256, p. 186-193.

Hooper, P.R. and Hawkesworth, C.J., 1993, Isotopic and geochemical constraints on the origin and evolution of the Columbia River basalt. Journal of Petrology, 34(6), pp.1203-1246. 
Hooper, P.R., Binger, G.B. and Lees, K.R., 2002, Ages of the Steens and Columbia River flood basalts and their relationship to extension-related calc-alkalic volcanism in eastern Oregon: Geological Society of America Bulletin, v. 114, p. 43-50.

Houston, R.A., McClaughry, J.D., Duda, C.J.M., and Ferns, M.L., 2017, Geologic Map of the Harney 7.5' Quadrangle, Harney County, Oregon.

James, D. E., 1981, The combined use of oxygen and radiogenic isotopes as indicators of crustal contamination. Annual Reviews of Earth and Planetary Sciences, 9, 311-344, Jarboe, N.A., Coe, R.S., Renne, P.R. and Glen, J.M., 2010, The age of the Steens reversal and the Columbia River Basalt Group: Chemical Geology, v. 274, p. 158-168.

Kasbohm, J. and Schoene, B., 2018, Rapid eruption of the Columbia River flood basalt and correlation with the mid-Miocene climate optimum: Science Advances, v. 4, DOI: $10.1126 /$ sciadv.aat 8223 .

Kleck, W.D., 1977, Chemistry, Petrography, and Stratigraphy of the Columbia River Group of in the Imnaha River Valley Region, Eastern Oregon and Western Idaho [Ph.D. thesis]: Washington State University, 217 p.

Kuiper, K.F., Deino, A., Hilgen, F.J., Krijgsman, W., Renne, P.R. and Wijbrans, J.R., 2008, Synchronizing rock clocks of Earth history: Science, v. 320, p. 500-504.

LaMaskin, T.A., 2013, Crustal growth by tectonic accretion of island arc terranes: Radioisotopic provenance of late Paleozoic-Mesozoic rocks of the Blue Mountains, western United States. GSA Annual Meeting in Denver.

LaMaskin, T.A., Vervoort, J.D. and Dorsey, R.J., 2008, Geochemical, isotopic and detrital zircon provenance of Mesozoic rocks, Oregon and Idaho, USA. GeCAS, 72(12), p.A513. 
Loewen, M.W. and Bindeman, I.N., 2015. Oxygen isotope and trace element evidence for three-stage petrogenesis of the youngest episode (260-79 ka) of Yellowstone rhyolitic volcanism. Contributions to Mineralogy and Petrology, 170(4), p.39.

Mahood, G.A. and Benson, T.R., 2017, Using 40Ar/39Ar ages of intercalated silicic tuffs to date flood basalts: Precise ages for Steens Basalt Member of the Columbia River Basalt Group: Earth and Planetary Science Letters, v. 459, p. 340-351.

McDougall, I., 1976. Geochemistry and origin of basalt of the Columbia River Group, Oregon and Washington. Geological Society of America Bulletin, 87(5), pp.777-792.

Moore, N.E., Grunder, A.L. and Bohrson, W.A., 2018, The three-stage petrochemical evolution of the Steens Basalt (southeast Oregon, USA) compared to large igneous provinces and layered mafic intrusions: Geosphere, v. 14, p. 2505-2532.

Morgan, W.J., 1981, Hotspot tracks and the opening of the Atlantic and Indian oceans, in Emiliani, C-, ed., The sea, Volume 7: New York, Wiley Interscience, p. 443-475. Nathan, S. and Fruchter, J.S., 1974, Geochemical and paleomagnetic stratigraphy of the Picture Gorge and Yakima basalts (Columbia River Group) in central Oregon: Geological Society of America Bulletin, v. 85, p. 63-76.

Onuma, N., Higuchi, H., Wakita, H. and Nagasawa, H., 1968, Trace element partition between two pyroxenes and the host lava. E\&PSL, 5, pp.47-51.

Peate, D.W., Barker, A.K., Riishuus, M.S., Andreason, R., 2008, Temporal variations in crustal assimilation of magma suites in the East Greenland flood basalt province: tracking the evolution of magmatic plumbing systems. Lithos 102, 179-197. 
Reidel, S.P., Camp, V.E., Tolan, T.L. and Martin, B.S., 2013, The Columbia River flood basalt province: Stratigraphy, areal extent, volume, and physical volcanology, in Geological Society of America Special Paper, 497, p. 1-43.

Robyn, T.L., 1979. Miocene volcanism in eastern Oregon: An example of calc-alkaline volcanism unrelated to subduction. Journal of Volcanology and Geothermal Research, 5(1-2), pp.149-161.

Saunders, A.D., 2005, Large igneous provinces: origin and environmental consequences. Elements, 1(5), pp.259-263.

Schoene, B., Samperton, K.M., Eddy, M.P., Keller, G., Adatte, T., Bowring, S.A., Khadri, S.F. and Gertsch, B., 2015, U-Pb geochronology of the Deccan Traps and relation to the end-Cretaceous mass extinction. Science, v. 347, p. 182-184.

Schwartz, J.J., Snoke, A.W., Frost, C.D., Barnes, C.G., Gromet, L.P. and Johnson, K., 2010. Analysis of the Wallowa-Baker terrane boundary: Implications for tectonic accretion in the Blue Mountains province, northeastern Oregon. Bulletin, 122(3-4), pp.517-536.

Schwartz, J.J., Snoke, A.W., Cordey, F., Johnson, K., Frost, C.D., Barnes, C.G., LaMaskin, T.A. and Wooden, J.L., 2011, Late Jurassic magmatism, metamorphism, and deformation in the Blue Mountains Province, northeast Oregon. Bulletin, 123(910), pp.2083-2111.

Self, S., Widdowson, M., Thordarson, T. and Jay, A.E., 2006, Volatile fluxes during flood basalt eruptions and potential effects on the global environment: A Deccan perspective. Earth and Planetary Science Letters, 248(1-2), pp.518-532. 
Standhaft, D., 2018. Textural and compositional analysis of early Miocene dacite lavas in Malheur National Forest, eastern Oregon: Testing models of granodiorite remobilization to yield dacite magmas (Masters Thesis, Portland State University and University of Greifswald).

Steiner, A.R., 2016. Field Geology and Petrologic Investigation of the Strawberry Volcanics, Northeast Oregon. Portland State University, Dissertation.

Steiner, A. and Streck, M.J., 2014. The Strawberry Volcanics: Generation of 'orogenic' andesites from tholeiite within an intra-continental volcanic suite centered on the Columbia River flood basalt province, USA. Geological Society, London, Special Publications, 385(1), pp.281-302.

Steiner, A. and Streck, M.J., 2018. Voluminous and compositionally diverse, middle Miocene Strawberry Volcanics of NE Oregon: Magmatism cogenetic with flood basalts of the Columbia River Basalt Group. Field Volcanology: A Tribute to the Distinguished Career of Don Swanson: Geological Society of America Special Paper, 538, pp.41-62.

Streck, M.J., Ferns, M.L. and McIntosh, W., 2015. Large persistent rhyolitic magma reservoirs above Columbia River Basalt storage sites: The Dinner Creek Tuff eruptive center, eastern Oregon. Geosphere, 11(2), p.226-235.

Streck, M.J., McIntosh, W., and Ferns, M.F. 2017. Columbia River Rhyolites: Agedistribution patterns and their implications for arrival, location, and dispersion of flood basalt magmas in the crust: Geological Society of America Abstracts with Programs, Session. 239, No. 7. 
Sun, S.S. and McDonough, W.F., 1989. Chemical and isotopic systematics of oceanic basalts: implications for mantle composition and processes. Geological Society, London, Special Publications, 42(1), pp.313-345.

Swanson, D.A., Wright, T.L., Hooper, P.R. and Bentley, R.D., 1979. Revisions in stratigraphic nomenclature of the Columbia River Basalt Group, in Contributions to Stratigraphy: U.S. Geological Survey Bulletin 1457-G, 59 p.

Takahashi, E. and Kushiro, I., 1983. Melting of a dry peridotite at high pressures and basalt magma genesis. American Mineralogist, 68(9-10), pp.859-879.

Thayer, T.P. 1957. Some relations of later Tertiary volcanology and structure in eastern Oregon. International Geological Congress 20th, Mexico, Sec. 1, Volcanologia del Cenozoico, 1, 231.

Todt, W., Cliff, R.A., Hanser, A., Hofmann, A.W., 1996. Evaluation of a ${ }^{202} \mathrm{~Pb}-{ }^{205} \mathrm{~Pb}$ double spike for high-precision lead isotope analysis. In: Hart, S.R., Basu, A., Earth Processes: Reading the Isotope Code, Vol. 95, AGU, pp. 429-437.

Waters, A., 1961. Stratigraphic and lithologic variations in the Columbia River Basalt: American Journal of Science, v. 259, p. 583-611.

Watkins, N.D. and Baksi, A.K., 1974. Magnetostratigraphy and oroclinal folding of the Columbia River, Steens, and Owyhee basalts in Oregon, Washington, and Idaho: American Journal of Science, v. 274, p. 148-189.

Webb, B.M., Streck, M.J., McIntosh, W., and Ferns, M.L. and 2018. The Littlefield Rhyolite and associated mafic lavas: Bimodal volcanism of the Columbia River magmatic province, with constraints on age and storage sites of Grande Ronde Basalt magmas: Geosphere, v. 15 , no. 1. 
Wells, R.E., 1990. Paleomagnetic rotations and the Cenozoic tectonics of the Cascade arc, Washington, Oregon, and California. Journal of Geophysical Research: Solid Earth, 95(B12), pp.19409-19417.

White, J.D., White, D.L., Vallier, T., Stanley Jr, G.D. and Ash, S.R., 1992. Middle Jurassic strata link Wallowa, Olds Ferry, and Izee terranes in the accreted Blue Mountains island arc, northeastern Oregon. Geology, 20(8), pp.729-732.

Wolff, J.A., Ramos, F.C., Hart, G.L., Patterson, J.D. and Brandon, A.D., 2008. Columbia River flood basalts from a centralized crustal magmatic system: Nature Geoscience, v. 1, p. 177-180.

Wolff, J.A. and Ramos, F.C., 2013. Source materials for the main phase of the Columbia River Basalt Group: Geochemical evidence and implications for magma storage and transport, in The Columbia River Flood Basalt Province: Geological Society of America Special Paper, 497, p. 273-291.

Wright, T.L., Grolier, M.J. and Swanson, D.A., 1973. Chemical variation related to the stratigraphy of the Columbia River basalt: Geological Society of America Bulletin, v. 84, p. 371-386. 


\section{CONCLUSION}

\section{RESEARCH SUMMARY}

Determination of mantle source components of continental basaltic magmas requires extensive petrological, temporal, and geochemical information. Isotopic variability within Cenozoic basalts of the western United States has been credited to mantle variability and small-scale heterogeneities in both the asthenospheric and lithospheric mantle. Major and trace element signatures within basaltic lavas and dikes, coupled with changing ages across a flood basalt province, supply fingerprints of underlying mantle dynamics and mantle components. As the more primitive basaltic magmas traverse the crust, they are prone to differentiation processes and crustal contamination which may mask a deep mantle signature. The resulting eruptive product may reflect a geochemical signal solely of these shallow processes.

This dissertation presents new temporal, spatial, and geochemical data for the Picture Gorge Basalt (PGB) and highlights its significance in context of the Columbia River Basalt Group (CRBG). This research presents the first ${ }^{40} \mathrm{Ar} /{ }^{39} \mathrm{Ar}$ geochronological work for basaltic lavas and dikes geochemically correlated with the PGB. These ages include lavas of the original mapped distribution of the PGB, but also basaltic samples with PGB composition among previously mapped but unnamed, or newly discovered basalt lavas and dikes across a wide swath of eastern Oregon. This distribution of PGB samples adds significant spatial extent and volume, and increases the overall eruptive volume of this flood basalt. Combining ages and distribution of PGB lavas and dikes with geochemical and isotopic trends illustrate involvement of at least two mantle components. My methods integrated fieldwork, geo-analytical techniques for 
geochemical and isotopic data, geochronological work, and thermodynamic modeling. The broader significance of this work revises timing and distribution of PGB lavas, and obtains a clearer picture of spatial and temporal relationships to other co-eval CRBG formations and the Strawberry Volcanics, as well as characterize mantle reservoirs for PGB relative other localized lavas.

Major findings identified through this research include:

- Eruptions of CRBG initiated with PGB volcanism at $>17 \mathrm{Ma}$

- PGB is the longest erupting CRBG unit, active from 17.23 to $15.76 \mathrm{Ma}$

- These dates suggest initial impingement of Yellowstone plume over a much larger spatial footprint

- Two temporal pulses of volcanism are seen in both PGB and potentially evident in other main-phase CRBG formations

- Samples with PGB composition extend lava flows and dikes of this CRBG unit much further south/southeast- and northeastward closing the exposure gap between PGB and Steens Basalt, and PGB and Imnaha Basalt, respectively.

- What has been viewed as Steens Basalt along the southern margin of my study area is likely PGB. These PGB exposures may have extended eastward into the Malheur Gorge and the northern margin of Steens Basalt may be moved southward.

- PGB flows also extend further northeast than previously mapped, increasing PGB distribution area up to approximately $40 \%$. 
- MELTS modeling and isotopic data suggest two contributing primitive endmembers (HMD \& RR): likely represent depleted mantle and enriched midocean ridge basalt sources

○ Cyclical influence from metasomatized (possibly crustal/ sediment) component

- Differences in oxygen isotope values between PGB and Steens Basalt suggest petrogenesis of these two CRBG formations may have been distinct

These findings modify the current petrogenetic model of PGB and when coupled with older and longer eruptive duration, changes ideas surrounding flood basalt storage, dynamics, and emplacement.

\section{FUTURE WORK}

During this geochronological work of PGB lavas and dikes, a temporal gap of approximately 400,000 ka was identified. This apparent gap in PGB ages also exists when compared to existing CRBG ages calculated with a ${ }^{40} \mathrm{~K}$ decay constant of $5.463 \times 10^{-10} / \mathrm{a}$ (Min et al., 2000) and a Fish Canyon Tuff age of 28.201 Ma (Kuiper et al., 2008). Additional geochronological work needs to be conducted to confirm this lull in CRBG eruptive activity. I hope to continue unraveling the volcanic history of CRBG lavas, specifically the Imnaha Basalt, to understand if the CRBG formation that best represents the plume is emplaced early or later during flood basalt volcanism. 
Secondly, Oligocene age basalts previously have not been identified south of the John Day Valley. These $\sim 25$ Ma basalts likely represent the underplated basalts for partial melting of Cretaceous granodiorites to produce the local dacitic lavas exposed. Exploration of these basalts provides an early framework for investigating signals of a reemerging plume during CRBG magmatism and something I hope to explore as part of my early career research.

Lastly, Giant Plagioclase Basalts (GPB) are characteristics of flood basalt provinces, including the CRBG. This research identified GPB lavas that are geochemically similar to the PGB, these lavas had previously been assumed to be compositionally similar to Steens Basalt. More interestingly, some of the largest plagioclase phenocrysts in the GPB's also contain macroscopic copper platelets. Recently, basaltic lavas in Ethiopia were also recognized to have metallic copper within plagioclase phenocrysts. Understanding the petrochemical processes surrounding copper partitioning into plagioclase phenocrysts in flood basalt provinces is the main focus of my future work.

\section{REFERENCES}

Kuiper, K.F., Deino, A., Hilgen, F.J., Krijgsman, W., Renne, P.R. and Wijbrans, A.J., 2008. Synchronizing rock clocks of Earth history. science, 320(5875), pp.500-504.

Min, K., Mundil, R., Renne, P.R. and Ludwig, K.R., 2000. A test for systematic errors in 40Ar/39Ar geochronology through comparison with $\mathrm{U} / \mathrm{Pb}$ analysis of a $1.1-\mathrm{Ga}$ rhyolite. Geochimica et Cosmochimica Acta, 64(1), pp.73-98. 


\section{$\underline{\text { APPENDICES }}$}




\section{APPENDIX A}

Sample Whole Rock (XRF \& ICP-MS) and Location Data

Sample location and geochemical data (XRF and ICP-MS analyses) attached as supplementary file.

File name: Appendix_A_XRF_ICPMS Geochemical and Sample Location Data

Type: .csv

File Size: $0.126 \mathrm{MB}$

Special Hardware: none 


\section{$\underline{\text { APPENDIX B }}$}

${ }^{40} \mathrm{Ar} /{ }^{39} \mathrm{Ar}$ Age Spectra (Plateaus and Inverse Isochrons)

${ }^{40} \mathrm{Ar} /{ }^{39} \mathrm{Ar}$ age spectra attached as supplementary file.

File name: Appendix_B_ArAr Age Spectra_Plateaus InverseIsochrons

Type: .pdf

File Size: $7.255 \mathrm{MB}$

Special Hardware: none 


\section{APPENDIX C}

\section{$\underline{\text { ArArCALC Summary Table }}$}

${ }^{40} \mathrm{Ar} /{ }^{39} \mathrm{Ar}$ age data attached as supplementary file.

File name: Appendix C_ArArCALC_SUMMARY

Type: .csv

File Size: $0.069 \mathrm{MB}$

Special Hardware: none 


\section{$\underline{\text { APPENDIX D }}$}

Major and Trace Elemental Comparisons of PGB Members

Major and trace element geochemical comparisons attached as supplementary file.

File name: Appendix_D_MajorTraceElementalComparisons_BaileyWolff

Type: .pdf

File Size: $2.325 \mathrm{MB}$

Special Hardware: none 


\section{APPENDIX E}

Major and Trace Elements versus Mg\# Plots

Major and trace element concentrations versus $\mathrm{Mg \#}$ attached as supplementary file.

File name: Appendix_E_MajorTraceElements_vs_Mg\#PGB

Type: .pdf

File Size: $4.170 \mathrm{MB}$

Special Hardware: none 


\section{$\underline{\text { APPENDIX F }}$}

$\underline{\mathrm{Sr}, \mathrm{Nd}, \mathrm{Hf}, \mathrm{Pb} \text { Isotopic Uncertainties and Potential Isobaric Interferences }}$

Summary table of radiogenic isotope errors and potential isobaric uncertainty ratios attached as supplementary file.

File name: Appendix_F_SrNdHfPb_IsotopicUncertaintyandIsobaricInterferences

Type: .csv

File Size: $0.014 \mathrm{MB}$

Special Hardware: none 


\section{$\underline{\text { APPENDIX G }}$}

Oxygen Isotope Summary Table

Oxygen isotope results, errors, and standards attached as supplementary file.

File name: Appendix_G_OXYGEN ISOTOPE DATA

Type: .csv

File Size: $0.015 \mathrm{MB}$

Special Hardware: none 


\section{APPENDIX H}

Summary Table of MELTS Modelling Results and Trace Element Calculations

File name: Appendix_H_MELTS Summary Table and Trace Element Calc

Type: .csv

File Size: $1.976 \mathrm{MB}$

Special Hardware: none 


\section{APPENDIX I}

Principal Component Analysis Code

Computer code used for statistical comparison attached as supplementary file.

File name: Appendix_I_PCA Code

Type: .r

File Size: $0.016 \mathrm{MB}$

Special Hardware 


\section{APPENDIX J}

\section{$\underline{\text { Onuma Diagrams }}$}

Onuma diagrams for partitioning data attached as supplementary file.

File name: Appendix_J_OnumaPlots

Type: .pdf

File Size: $0.573 \mathrm{MB}$

Special Hardware: none 